PEDRO HENRIQUE DE ARARIPE SUCUPIRA

\title{
COLETIVIZAÇÃO DE DEMANDAS INDIVIDUAIS
}

Dissertação de mestrado apresentada à Faculdade de Direito da USP, na área de concentração de Direito Processual, como requisito para obtenção do título de Mestre.

Orientador: Prof. Dr. Kazuo Watanabe.

Faculdade de Direito da UniVersidade de São Paulo

SÃo PAULO

2014 


\section{DEDICATÓRIA}

Aos meus pais, George e Thereza. 
AGRADECIMENTOS

Ao meu orientador, Professor Doutor Kazuo Watanabe.

À minha família, pelo amor eterno.

À minha Nayara, sem a qual nada disso seria possível. 


\section{RESUMO}

O objeto do estudo diz respeito a como demandas individuais podem resultar em demandas coletivas. Interesses são relações entre necessidades e os bens capazes de satisfazê-las. Nesse sentido, interesses podem ser entendidos como uma demanda por um bem. Interesses coletivos se relacionam a bens capazes de satisfazer necessidades de uma coletividade. O conflito de interesses ocorre nos casos em que o atendimento a um interesse importa a denegação de outro. O Direito pode ser visto como um instrumento ético de resolução de conflito de interesses. O processo civil tradicionalmente foi concebido para a resolução de conflitos individuais. Com o reconhecimento dos interesses coletivos pelo Direito, novas técnicas processuais foram desenvolvidas para permitir a resolução de conflitos coletivos. Apesar disso, o número de demandas individuais relacionadas com questões coletivas cresce exponencialmente, causando o congestionamento de processos nos tribunais e a denegação de justiça. Questões estruturais, culturais e legais são fatores que levam a esse problema. Novas técnicas deveriam ser implementadas para a conversão de demandas individuais em demandas coletivas nos casos em que o seu objeto seja incindível e pertinente a uma coletividade.

Palavras-chave: interesses coletivos, conflito de interesses, efetividade, coletivização de demandas. 


\begin{abstract}
The scope of the study pertains to how individual claims may result in collective (aggregated) claims. Interests are relationships between needs and the goods that can fulfill them. In this sense, interests can be conceived as a claim for a good. Collective interests relate to goods that are able to satisfy needs of a group of people. A conflict of interests takes place when the accomplishment of one precludes the other. The Law may be conceived as an ethical tool to the resolution of conflict of interests. Traditional litigation schemes were designed for the resolution of individual conflicts. With the recognition of collective rights by the Law, new civil procedure techniques were developed to allow resolution of collective conflicts. Despite that, the number of individual claims related to collective issues grows exponentially, causing a backlog of cases and the denial of justice. Structural, cultural and legal issues are factors leading to this problem. New techniques should be designed to convert individual claims into collective claims in cases where their object is indivisible and pertains to a group.
\end{abstract}

Keywords: public interests, conflict of interests, acces to justice, aggregation of claims. 


\section{SUMÁRIO}

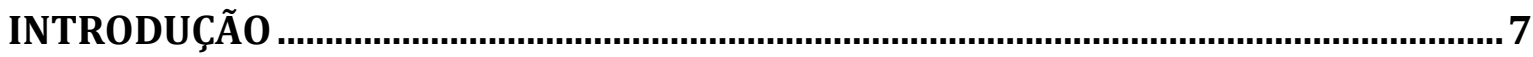

1a Parte - COLETIVIZAÇÃO MATERIAL: OS INTERESSES METAINDIVIDUAIS ...... 10

CAPÍTULO 1. Conceito de interesse e as relações que estabelece ....................................11

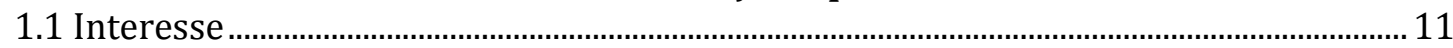

1.2 Relação entre interesses ..................................................................................................... 19

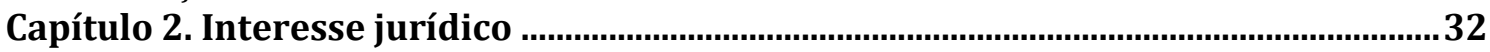

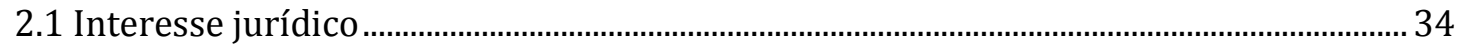

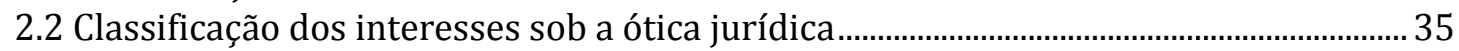

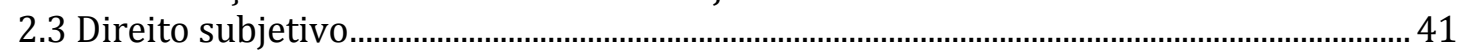

Capítulo 3. Interesses individuais e metaindividuais....................................................55

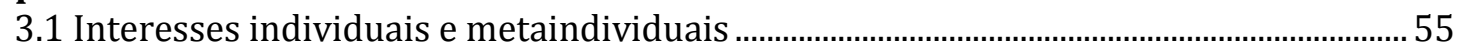

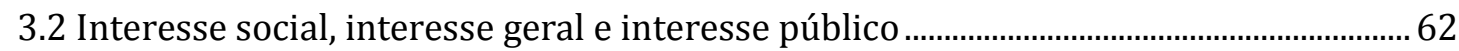

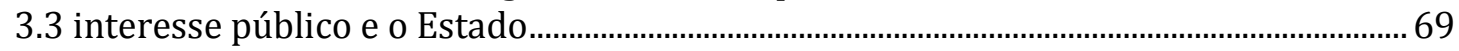

3.4 A determinação do interesse público ................................................................................73

3.5 Interesse público como conceito jurídico indeterminado ................................................. 75

3.60 processo de transmutação do interesse público homogêneo para os interesses

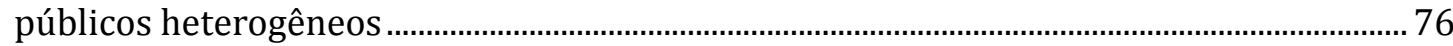

3.7 Fragmentação social e o Estado Pluriclasse ……………………………………………....... 78

3.8 A definição do interesse público na sociedade fragmentada ............................................. 80

3.9 Conflitos envolvendo o interesse público.............................................................................. 87

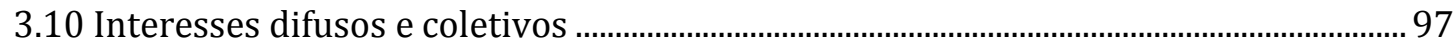

3.11 Interesses difusos ................................................................................................100

3.12 Interesses coletivos em sentido estrito ..........................................................................104

3.13 Relação entre interesses difusos e coletivos com o interesse público..........................105

2 a Parte - COLETIVIZAÇÃ̃o PROCESSUAL: AS AÇõES COLETIVAS...........................109

Capítulo 1. Processos coletivos ......................................................................................110

1.1 Processo individual para o coletivo ……………............................................................110

1.2 Processos coletivos para a tutela de interesses difusos e coletivos ...............................124

1.3 Processos coletivos para a tutela de interesses individuais homogêneos .....................131

1.4 Demandas coletivas em espécie .....................................................................................135

1.5 Aggregate litigation (litigância agregada) nos Estados Unidos da América ................137

1.6 Subsistema brasileiro das ações coletivas.........................................................................139

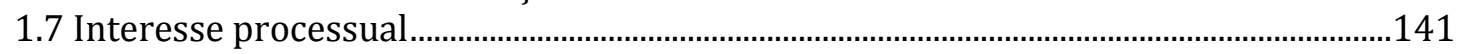

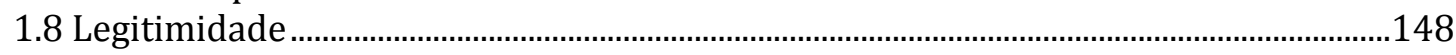

1.9 Relações entre demandas.......................................................................................................164

Capítulo 2. A patológica multiplicação de demandas individuais................................. 177

2.1 Proliferação de processos individuais no âmbito coletivo ...............................................177

2.2 Efeitos da multiplicação de demandas repetitivas .............................................................181

2.3 Efetividade processual ……………………………...............................................................183

2.4 Efetividade e tempo.............................................................................................................186

2.5 Exame do problema sob a perspectiva instrumentalista...................................................189

2.6 A coletivização de demandas individuais ou pseudoindividuais.....................................199

2.7 A legitimidade individual para a ação coletiva......................................................................215

2.80 Código de Processo Civil projetado........................................................................................219

CONCLUSÃO

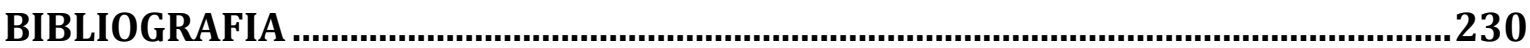




\section{INTRODUÇÃO}

O objeto do trabalho consiste no estudo do tratamento coletivizado de demandas individuais. Colocando-se de outra forma, será analisado como a busca pelo reconhecimento e a efetividade daquilo que um sujeito entende ser a satisfação de sua necessidade deveria ser dimensionada de maneira coletiva, produzindo efeitos também para terceiros.

A análise pressupõe o entendimento do que venha a ser uma demanda. De forma semelhante a diversos outros termos, trata-se de um conceito plurívoco. Para a doutrina processualista tem um significado técnico definido ${ }^{1}$.

Entretanto, como o direito processual sob a perspectiva jurídica tem um caráter instrumental com relação ao direito material, tendo como um de seus escopos sociais a pacificação social com justiça, há de se considerar o fenômeno que antecede a formação da demanda processual e que ocorre na realidade palpável do dia a dia.

Aqui está a se referir, por extensão, às demandas materiais que acometem os seres humanos no curso de toda a sua vida, e que, no mais das vezes, não levam a um conflito jurisdicionalizado. Não só as demandas entendidas em termos econômicos, abrangendo também aquelas referentes a objetos comumente não tomados pelo seu conteúdo material e sim pelos valores éticos ou morais a eles atrelados, como a qualidade de vida ou a vida digna.

As demandas, em ambos os sentidos expostos, veiculam interesses, podendo ser entendidas como uma forma de expressão dos mesmos. Um interesse nada mais é do que a demanda de um sujeito por um bem em sentido lato. Enquanto a demanda material traduz um interesse por um bem da vida, a demanda processual representa o interesse por uma tutela estatal tendo em vista o atendimento de um interesse material.

\footnotetext{
1 "O ato inicial de comparecimento a juízo com uma pretensão chama-se demanda. Demandar é pedir, postular. Demanda é um ato e não se confunde com ação, que é um direito, ou poder" (DINAMARCO, Cândido Rangel. Instituições de Direito Processual Civil. Vol. I. 5. ed. São Paulo: Malheiros, 2005, p. 322).
} 
Assim, a investigação tem seu ponto de partida na noção de interesse, considerando que as demandas nascem tendo por substrato conflitos de interesses ${ }^{2}$. Delineado o conceito que serve de viga mestra para o estudo, examina-se como no campo da realidade os interesses podem se relacionar entre si, seja de forma positiva - se o aperfeiçoamento de um interesse favorecer o de outro -, seja de forma negativa - nas hipóteses em que a prevalência de um se dá em detrimento do outro ${ }^{3}$.

Da noção geral de interesse, reconhecendo-se a necessidade de proteção de alguns para que se sobreponham em caso de conflito, extrai-se o interesse jurídico e sua correlação com o direito subjetivo. Baseando-se essas noções na dimensão individual, passa-se ao exame de sua expressão na dimensão metaindividual ou coletiva. Concebem-se, assim, as diversas manifestações desses interesses metaindividuais pelas formas em que são reconhecidos pelo Direito. A esse respeito, serão considerados os conceitos de interesse social, geral, público, coletivo e difuso, e como a sua proteção pelo Direito representou um fenômeno de coletivização de demandas individuais.

Ingressando no plano processual, apura-se como a função de resolução de conflitos evolui, de uma estrutura individualista, para admitir e dar tratamento a litígios de repercussão coletiva.

Examina-se, então, a coletivização processual dos interesses, por meio do instituto dos interesses individuais homogêneos.

Ponderando a respeito do que consiste um processo coletivo, comparando com as técnicas de agregação existentes nos Estados Unidos, considera-se a formação de um sistema de processos coletivos no Brasil.

\footnotetext{
${ }^{2}$ SANTOS, Moacyr Amaral. Primeiras Linhas de Direito Processual Civil, vol. 1. 2. ed. São Paulo: Max Limonad, 1965, p. 23.

${ }^{3}$ Ressalve-se, todavia, o entendimento de Tércio Sampaio Ferraz Junior de que os interesses e os conflitos de interesses não configuram tema central para o Direito. Nas palavras do autor: "A sociedade não é um conjunto de interesses, nem todos os problemas jurídicos resultam de conflitos de interesses. Há conflitos jurídicos que não têm nada a ver com interesse propriamente dito (por exemplo, conflitos de competência). Há situações em que os interesses sequer aparecem. Nesse sentido, não há necessidade ou não há o bem e, não obstante, existem conflitos". (FERRAZ JUNIOR. Interesse Público. Disponível em http://www.terciosampaioferrazjr.com.br/?q=/publicacoes-cientificas/31. Acessado em 10 de dezembro 2013.
} 
Investiga-se, na sequência, como se apresentam as noções de interesse processual e de legitimidade na esfera das demandas coletivas, para depois se examinar as relações que podem estabelecer entre si e com demandas individuais.

A respeito do fenômeno das demandas repetitivas, cogita-se quais seriam suas causas, os efeitos deletérios que acarreta e os mecanismos que vem sendo adotados para lhe dar tratamento.

Por fim, apura-se a possibilidade de demandas propostas como individuais, na realidade, referirem-se a relação jurídica substancial incindível, de forma a tornar inapropriado o seu processamento individualizado. Nesse caso, cogita-se a possibilidade de conversão de aludidas demandas em demandas coletivas.

A discussão em comento se justifica na medida em que, embora os conflitos submetidos à análise pelo nosso sistema jurídico sejam por vezes idênticos, as decisões proferidas são em sua grande parte contraditórias, gerando insegurança e injustiça. Destaque-se, ainda, que referidas decisões são proferidas mediante grandes gastos processuais e após o decorrer de muito tempo. Em face do escopo do Direito, que é justamente a pacificação dos conflitos sociais e harmonização da sociedade, é patente que a repetição de demandas idênticas e a correspondente prolação de decisões discrepantes, morosas e dispendiosas é incompatível com o acesso à ordem jurídica justa. Daí a importância de se identificar demandas individuais com verdadeira natureza coletiva, bem como os meios da instrumentalização do seu tratamento no âmbito coletivo. 
$1^{\text {a }}$ PARTE - COLETIVIZAÇÃO MATERIAL: OS INTERESSES METAINDIVIDUAIS 


\section{CAPÍTULO 1. CONCEITO DE INTERESSE E AS RELAÇÕES QUE ESTABELECE}

\subsection{INTERESSE}

O vocábulo interesse é polissêmico, sendo empregado para designar diferentes objetos em diversas áreas do conhecimento ${ }^{1}$. No campo jurídico, apesar de haver quem o considere conceito jurídico indeterminado ${ }^{2}$, atribui-se-lhe um conteúdo central ao redor do qual gravitam suas inúmeras qualificações, representando conceito de fundamental importância não só para o direito processual civil, como para o Direito em geral ${ }^{3}$.

Associa-se o conceito de interesse à ideia de vantagem. A presença de ao menos dois elementos é imprescindível para que ela ocorra, eis que só se faz possível se um experimentar o benefício e outro o proporcionar. Há vantagem se esses elementos existirem e entre eles se estabelecer uma relação de tal forma que o segundo sirva ao primeiro deixando-o em uma situação mais favorável da que ocupava previamente. Despido desses elementos e da relação entre eles estabelecida, fica o conceito de interesse sem significância ${ }^{4}$.

\footnotetext{
${ }^{1}$ MANCUSO, Rodolfo de Camargo. Interesses Difusos: conceito e legitimação para agir. 6. ed. São Paulo: Revista dos Tribunais, 2004, p. 25. Aluisio Gonçalves de Castro Mendes apresenta um rol de significados assumidos pelo vocábulo: "No plano comum ou técnico, a palavra dispõe de variada significação, podendo representar lucro material ou pecuniário, ganho; juro; parte ou participação que alguém tem nalguma coisa; vantagem, proveito, benefício; aquilo que convém; sentimento de cobiça, avidez, mas, também, zelo, simpatia, preocupação ou curiosidade por alguém ou alguma coisa; empenho; relação de reciprocidade entre um indivíduo e um objeto que corresponde a uma determinada necessidade daquele." (MENDES, Aluisio Gançalvez de Castro. Ações Coletivas no Direito Comparado e Nacional. 2. ed. rev. atual. e ampl. São Paulo: Revista dos Tribunais, 2010, p. 205).

${ }^{2}$ Aluisio Gonçalves de Castro Mendes anota que para Gerhard Köbler trata-se de um conceito jurídico indeterminado, cujo conteúdo somente pode ser aferido ao se interpretar a norma jurídica que contempla cada interesse em questão. (MENDES, 2010, p. 205).

${ }^{3}$ CARNELUTTI, Francesco. Sistema de Direito Processual Civil. vol. I. Tradução de Hiltomar Martins Oliveira. São Paulo: Classic Book, 2000, p.55.

${ }^{4}$ Aluisio Gonçalves de Castro Mendes destaca o entendimento de Karl Thiere, segundo o qual a idéia isolada e abstrata de interesse não possui conteúdo, tomando significância ao ser considerada em associação com sujeito que lhe é titular e o bem que compõe o seu objeto. Percebe-se, a partir daí, a importância daqueles elementos para o conceito de interesse. (MENDES, 2010, p. 206).
} 
A formação etimológica do termo, com origem na expressão latina quod inter est ${ }^{5}$, ou aquilo que está entre, revela que no seu cerne está uma relação entre dois elementos: sendo o primeiro o sujeito e o segundo o objeto, marcada pelo proveito que aquele obtém deste.

Rodolfo de Camargo Mancuso, com base nas definições clássicas de Henri Capitant e Eduardo Couture, afirma que, constituindo uma vantagem de ordem pecuniária ou moral, "o interesse interliga uma pessoa a um bem da vida, em virtude de um determinado valor a que esse bem possa representar para aquela pessoa"6.

Expressando o conceito por outra fórmula, mas com similar conteúdo, Francesco Carnelutti sintetiza a definição de interesse como "a posição favorável à satisfação de uma necessidade"7. Ele se perfaz na relação entre um homem e um bem na qual este proporciona a satisfação de uma necessidade daquele ${ }^{8}$. O sujeito dessa relação é o homem, que experimenta necessidades, e o objeto é o bem, que possui a aptidão de satisfazê-las ${ }^{9}$. Ilustrando sua proposição, Francesco Carnelutti cita a posse do alimento, que representa o interesse do homem em função da sua necessidade de nutrir-se. Estabelecendo-se essa interação entre dois elementos na qual um serve ao outro, considera-se tratar-se o interesse de uma relação de complementariedade ${ }^{10}$.

A ligação entre sujeito e objeto dá-se pela relação entre a necessidade experimentada e a capacidade do bem de supri-la. A necessidade consiste na tendência que um ser vivo tem para combinar-se com um ente complementar. Chama-se utilidade a capacidade deste ente

\footnotetext{
${ }^{5}$ MENDES, 2010, p. 205. ALVIM, José Eduardo Carreira. Teoria Geral do Processo. 15. ed. Rio de Janeiro: Forense, 2012, p. 3.

${ }^{6}$ MENDES, 2010, p. 19. Em sentido semelhante, Susana Henriques da Costa afirma ser a "pretensão que alguém tem em relação a determinado bem, a que se atribui algum valor econômico ou moral". (COSTA, Susana Henriques da. O Processo coletivo na Tutela do Patrimônio Público e da Moralidade Administrativa: ação de improbidade administrativa, ação civil pública e ação popular. São Paulo: Quartier Latin, 2009, p. 44.

${ }^{7}$ COSTA, 2009, p. 55.

${ }^{8}$ CARNELUTTI, Francesco. Teoria Geral do Direito. Tradução de Antônio Carlos Ferreira. São Paulo: Lejus, 2006, p. 89.

${ }^{9} \mathrm{O}$ conceito de Francesco Carnelutti é empregado na sua essência por diversos autores, mesmo que com certa reformulação. Assim, para José Renato Nalini, por exemplo, interesse "é o desejo de conseguir um bem, estimulado pela idoneidade que esse bem oferece à satisfação de uma necessidade". (NALINI, José Renato. Direito Subjetivo, Interesse Simples, Interesse Legítimo. Revista de Processo, $\mathrm{n}^{\mathbf{o}}$ 38, ano 10, abril-junho de 1985, pp. 240/250).

10 "Diz-se que dois entes são complementares quando, segundo a previsão (fundada em regras de experiência) do desenvolvimento da situação de que fazem parte em um fato, são capazes de combinar-se (sic) em uma nova situação casualmente ligada à situação precedente. Chave e fechadura, pena e tinta, espingarda e projétil, apresentam entre sim uma relação deste gênero. O mesmo se diga do homem ou do animal e da alimentação que pode matar-lhes a fome, ou da arma que os pode ferir." (CARNELUTTI, 2006, p. 55).
} 
de satisfazer uma necessidade. Nesse contexto, pode a noção de interesse ser reduzida à "utilidade específica de um ente para outro ente" ${ }^{11}$.

Alf Ross estabelece dois sentidos para a palavra interesse: um, de cunho lato, designa "todo estado de consciência que encerra uma atitude", de forma a que haja interesse em tudo o que desperte uma experiência positiva ou negativa no indivíduo; e outro, de ordem estrita, significando a ordem de atitudes de uma pessoa fundadas em necessidades. $\mathrm{O}$ autor toma por necessidade um estado de carência, com bases em um mecanismo biológico de autorregulação, que leva o indivíduo a atividades que fazem cessar tal estado, manifestado como uma experiência com raiz psicológica de descontentamento ou anseio relativamente a algo. Nesse contexto, há necessidades corporais, ligadas a aspectos materiais, tais como alimentos, abrigo e descanso, bem como necessidades espirituais, ligadas a aspectos imateriais, como auto-afirmação, auto-respeito e conhecimento. A identificação dos objetos capazes de satisfazer necessidades decorre do aprendizado humano com base na experiência. Partindo dessas considerações, Alf Ross conceitua o interesse em sentido estrito como a atitude em relação a um objeto de que a pessoa tenha consciência ser objeto de sua necessidade, resultante da experiência de tal pessoa com relação às diversas fases dessa necessidade ("anseio, esforço, satisfação") ${ }^{12}$.

Necessidades não são ínsitas apenas ao homem, mas sim a todos os seres vivos. Os organismos vivos experimentam continuamente necessidades para manterem-se vivos, reproduzirem-se e perpetuarem suas espécies, a nenhum sendo dado o dom de viver sem depender de elementos do ambiente. Alimento, água, abrigo contra intempéries e predadores são apenas alguns dos objetos de tais necessidades. Por mais que sob o prisma do direito, sejam o homem e as atividades e relações por ele desenvolvidas postos em destaque, não há de se negar que fenômenos afins possam ser observados na natureza ${ }^{13}$.

\footnotetext{
${ }^{11}$ CARNELUTTI, 2006, p. 89.

${ }^{12}$ ROSS, Alf. Direito e Justiça. Tradução e notas de Edson Bini. 1. ed. Bauru: Edipro, 2003, pp. 409/411. Na visão de Alf Ross o interesse não serve de motivação para toda e qualquer ação humana. Dentre aquelas que considera desinteressadas, elenca os reflexos, que ocorrem se conhecimento e vontade; as ações sugeridas ou persuadidas, decorrentes de impulsos de ação espontâneos transmitidos por meios de persuasão linguísticos e não linguísticos, como, por exemplo, a ordem dos pais para que os filhos interrompam certa atividade perigosa; e as atitudes morais, principalmente ao se experimentar a moral como um dever. Em nenhum desses casos, as ações estariam voltadas à satisfação de alguma necessidade, a alguma vantagem ou utilidade. (ROSS, 2003, pp. 416/417).

${ }^{13}$ Francesco Carnelutti reconhece que não só as necessidades, como também os interesses não se restringem ao homem, sendo representados em fenômenos da natureza. (CARNELUTTI, 2006, p. 87).
} 
De acordo com Francesco Carnelutti, a força vital nada mais é do que o estímulo dos seres vivos para combinarem-se com entes complementares. "O estímulo age por via de uma sensação penosa por todo o tempo em que se não efetue a combinação e de uma sensação agradável logo que a combinação se produza." ${ }^{14}$. Entende-se por necessidade essa "tendência de combinação de um ente vivo com um ente complementar" ${ }^{15}$, sendo a necessidade satisfeita justamente por essa combinação. Vê-se, sob essa perspectiva, que o conceito de necessidade pressupõe a possibilidade dessa combinação, ou seja, que haja um ente capaz de aplacá-la.

As necessidades são associadas a finalidades. Necessita-se de algo sempre para algum fim. Essas finalidades são de diversas ordens e graus de importância. Algumas, por exemplo, dizem respeito à sobrevivência ou subexistência, à manutenção de uma vida digna ${ }^{16}$, outras são pertinentes ao conforto e ao convívio social.

O rol das necessidades humanas é vasto e variável de acordo com as circunstâncias. Necessidades podem ser eliminadas, mitigadas, criadas ou exacerbadas. As variações na moda ilustram essa questão. A utilização de certos artigos de vestimenta, como, por exemplo, o chapéu, em dados momentos históricos constitui uma necessidade compartilhada socialmente, em outros, não só pode deixar de ser uma necessidade, como passar a ser alvo de críticas.

$\mathrm{Na}$ sociedade de consumo em massa, não só novos serviços e bens de consumo são desenvolvidos, mas também as necessidades por esses novos produtos e serviços são semeadas nos consumidores ${ }^{17}$. Há algumas décadas, computadores pessoais, telefones móveis e a rede mundial de computadores, por exemplo, não existiam ou eram acessíveis a

\footnotetext{
${ }^{14}$ CARNELUTTI, 2006, p. 86.

${ }^{15}$ CARNELUTTI, 2006, p. 86.

${ }^{16}$ A doutrina recentemente desenvolveu o conceito de mínimo existencial como núcleo duro das exigências para uma vida digna do ser humano, mas cujo conteúdo varia em razão de circunstâncias de lugar, tempo e culturais (WATANABE, Kazuo. Controle Jurisdicional de Políticas Públicas - "Mínimo Existencial" e Demais Direitos Fundamentais. In: GRINOVER, Ada Pellegrini; WATANABE, Kazuo (Coord.). O controle jurisdicional de políticas públicas. Rio de Janeiro: Forense, 2011, p. 217).

17 Privilegia-se a produção de bens que proporcionam a satisfação temporária de necessidades dos consumidores, já com o objetivo de que novos sejam desenvolvidos e substituam os anteriores. Na sociedade de massa contemporânea, alude-se ao fenômeno da obsolescência programada ou planejada para designar a prática das empresas de desenvolverem produtos com vida útil diminuída, elevados custos de reparo ou que se tornem desatualizados em razão do lançamento de novas versões com novo design ou que incorporem novas funcionalidades ou tecnologias, tudo com o propósito de levar o consumidor a adquirir novos produtos.
} 
um número restrito de pessoas. Hoje, são instrumentos essenciais para grande parte da população que os tem incorporados no seu cotidiano.

Aquelas necessidades mais básicas normalmente são manifestadas pelos estímulos a que se refere Francesco Carnelutti, sem que se vinculem a uma base racional. A fome e a sede são os estímulos que representam as necessidades de nutrição e hidratação para a manutenção da vida. Esses estímulos, entretanto, não são imprescindíveis para que se caracterize uma necessidade. Distúrbios alimentares, por exemplo, podem eliminar a sensação de fome de um determinado indivíduo, sem que isso signifique que ele esteja nutrido. Por isso é que a definição das necessidades pode depender da percepção que o ser humano tem da realidade e do juízo que formule a seu respeito. Mesmo sem experimentar fome, tem-se consciência da necessidade da ingestão de alimentos. A necessidade de proteção contra certas substâncias e energias nocivas, por exemplo, depende do conhecimento que se tenha de tais substâncias e energias, bem assim de seus efeitos nocivos ${ }^{18}$. Os asbestos foram empregados indiscriminadamente como matéria prima na indústria até que os riscos associados à exposição a esse material quando disperso no ar tornaram-se conhecidos e levaram à medidas protetivas, como a proibição do uso industrial de algumas de suas espécies.

A esse respeito, Francesco Carnelutti reconhece que a existência da necessidade pode resultar não só de uma sensação, como também de uma dedução ${ }^{19}$, a qual não deixa de constituir uma forma de juízo a respeito da realidade. Partindo de sensações experimentadas, o sujeito induz uma regra geral a respeito da realidade, da qual deduz necessidades futuras. Admite-se, assim, a existência de interesses baseados não só em necessidades presentes, como também necessidades futuras. Ao acúmulo de bens para a satisfação de necessidades antecipadas dá-se o nome de poupança.

Para a Economia, uma mera aspiração humana somente caracteriza necessidade na medida em que acarrete uma ação do seu portador. Conforme aponta Fábio Nusdeo, ela "não passa de um desejo, socialmente manifestado, o qual leva a uma ação por parte de quem o

\footnotetext{
${ }^{18}$ Exemplos se multiplicam na história, como no caso da radioatividade e dos raios solares ultravioletas, que passaram a demandar maiores cuidados com o desenvolvimento do conhecimento científico a respeito do perigo que representam para a saúde humana.

${ }^{19}$ CARNELUTTI, 2006, p. 86.
} 
experimenta" 20. Aquelas aspirações que se mantém reclusas no âmbito interno do indivíduo não são relevantes para fins econômicos. Esses anseios, contudo, podem ter significância sob a ótica do Direito, servindo este como instrumento para que sejam manifestados, superarando óbices materiais que os reprimam, ou como mecanismo de repressão com o objetivo de evitar sua manifestação.

Tal diferença decorre da forma pela qual se enxerga o conteúdo da necessidade. Enquanto para a economia é irrelevante qual seja ele, o mesmo não se aplica quanto ao Direito, que retrata os valores socialmente considerados relevantes. A Economia não diferencia o vício por drogas, que leva ao consumo de tais substâncias, de outras necessidades socialmente toleradas $^{21}$. O Direito, entretanto, muitas vezes é empregado como instrumento de repressão a esse consumo e, assim, à manifestação da necessidade que o acarreta.

Os entes capazes de satisfazer as necessidades são os bens ou bens da vida ${ }^{22}$. O termo bem deriva etimologicamente da expressão latina bonum quod beat, que significa porque faz bem $^{23}$. Compreende as coisas corpóreas e incorpóreas ${ }^{24}$. O próprio homem, além de sujeito, também pode vir a ocupar a posição de objeto de interesses, mesmo não sendo considerado coisa hodiernamente ${ }^{25}$. Para Karl Thiere, segundo exposição de Aluisio Gonçalves de Castro Mendes, o objeto do interesse é o bem, considerado tal conceito em sua mais ampla dimensão, incluindo os bens materiais e intelectuais ou morais ${ }^{26}$. Atribuindo-lhe amplitude semelhante, Ugo Rocco considera bem tudo aquilo capaz de satisfazer uma necessidade, compreendendo tanto os materiais, tais como a água e o alimento, quanto os imateriais, como a paz e o amor, bem assim ações e omissões, o homem, relações de fato e relações jurídicas ${ }^{27}$.

Utilidade é a aptidão do bem de satisfazer uma dada necessidade. Muitas vezes bens diversos apresentam utilidade com relação à satisfação de uma mesma necessidade. São

\footnotetext{
${ }^{20}$ NUSDEO, Fábio. Curso de Economia: introdução ao Direito Econômico. 1. ed. São Paulo: Revista dos Tribunais, 1997, p. 34.

${ }^{21}$ NUSDEO, 1997, p. 35.

${ }^{22}$ ALVIM, 2012, p. 2.

${ }^{23}$ CARNELUTTI, 2006, p. 86.

${ }^{24}$ Francesco Carnelutti critica a expressão coisas incorpóreas aduzindo que todas as coisas tem um corpo, mesmo aquelas espirituais tais como a obra literária ou a ideia, que tomam corpo na forma em que são expressas (CARNELUTTI, 2006, p. 241).

${ }^{25}$ CARNELUTTI, 2006, pp. 223 e 241/246.

${ }^{26}$ MENDES, 2010, p. 206.

${ }^{27}$ Apud ALVIM, 2012, p. 2.
} 
esses bens chamados na Economia de sucedâneos ${ }^{28}$. Diferentes tipos de alimentos são capazes de satisfazer a fome, sendo considerados sucedâneos. Algumas enfermidades podem ser tratadas com o uso de medicamentos distintos que servem à mesma finalidade. O grau de utilidade entre bens sucedâneos pode variar, seja em razão de preferencias ou peculiaridades pessoais, daí porque se dizer tratar-se de um conceito subjetivo ${ }^{29}$, seja em razão da relação de tais bens com outras necessidades experimentadas. Em razão de preferências alimentares pessoais, é possível que um determinado alimento não seja tão útil quanto outros para determinado indivíduo. Um medicamento destinado ao tratamento de certa enfermidade pode ser ineficaz para um determinado enfermo em razão de peculiaridades de seu organismo. Ou então, por mais que para ele seja eficaz, causa-lhe efeitos colaterais indesejados, como no caso de gestantes para as quais não se recomendam certas espécies de medicamentos capazes de causar a má-formação dos fetos.

Para a Economia, o fato de um bem ser efetivamente útil tem menor importância do que o de ele ser considerado útil. A representação que os indivíduos fazem a respeito da utilidade de um bem é que os move a buscá-lo para satisfazer suas necessidades. Para o Direito, a utilidade dos bens é relevante em inúmeros aspectos. No Direito do Consumidor, sob a égide do Código de Defesa do Consumidor, constitui propaganda enganosa aquela em que se anuncia um produto ou serviço como se dotado de qualidades que não possui, gerando direitos para o consumidor influenciado por tal propaganda. Na mesma esfera, considera-se viciado o produto ou serviço que não se presta aos fins para os quais ele ordinariamente é empregado. Daí porque é possível interpretar tal norma como um dever de fornecimento de bens e serviços no mercado de consumo dotados da utilidade mínima costumeira a produtos e serviços da mesma espécie ${ }^{30}$.

A utilidade de um bem pode vir a ser tamanha que leve à limitação do direito de propriedade. A doutrina da função social da propriedade, em virtude da imensa utilidade de que são dotados os bens, impõe ao seu proprietário sanções caso não se lhe dê destinação legítima. De forma semelhante, normas de Direito Ambiental, devido à utilidade que os bens ambientais apresentam para a coletividade, também impõem restrições e deveres para o proprietário de glebas, como, por exemplo, o de preservar certa parcela do imóvel

\footnotetext{
${ }^{28}$ NUSDEO, 1997, pp. 42/43.

${ }^{29}$ NUSDEO, 1997, p. 35 e 43.

${ }^{30}$ Artigos 18 e 20 do Código de Defesa do Consumidor.
} 
chamado de reserva legal, o de limitações ao desflorestamento e ao aproveitamento de recursos hídricos.

Fato é que da mesma forma que as necessidades podem ou não corresponder a carências reais sofridas pelo indivíduo, a utilidade proporcionada por um bem da vida pode não ser aquela que dele se espera. Por mais que o conhecimento científico não se tenha provado isento de falhas, as crendices populares fornecem exemplos mais evidentes de tal afirmação. Não há garantias de que um trevo de quatro folhas ou um pé de coelho proporcione boa sorte para o seu possuidor. Isso não descaracteriza a relação entre o sujeito e o bem como um interesse. Por mais que o artigo possa não trazer a desejada boa sorte, terá a aptidão de satisfazer a necessidade de um amuleto manifestada pelo seu possuidor. Conforme afirma Francesco Carnelutti, um "ente é objeto de interesse na medida em que uma pessoa pense que lhe possa servir; de contrário, é indiferente" ${ }^{31}$.

Essa potencial diferença entre aquilo que se julga ser uma necessidade do sujeito ou a utilidade de um bem da vida e aquilo que caracterize uma efetiva necessidade ou utilidade, leva a divergências acerca do que constitua o interesse.

A concepção subjetiva do interesse ${ }^{32}$ considera-o não uma relação, mas sim um juízo. De acordo com Ugo Rocco, trata-se de um ato de inteligência do homem a respeito de um bem, uma necessidade e da aptidão desse bem de satisfazê-la. É, assim, um juízo formulado pelo ser humano a respeito dessa tríplice representação ${ }^{33}$. Mesmo que não exista a necessidade ou o bem, ou ainda que este não tenha a capacidade de satisfazê-la, verificaria-se o interesse caso essa relação esteja representada no intelecto do homem, formando-se um juízo a esse respeito, sendo irrelevante que tal juízo não corresponda à realidade.

Para Francesco Carnelutti, os defensores da concepção subjetiva do interesse confundem a realidade com a revelação da realidade. O interesse, enquanto relação, não seria um juízo, sendo o juízo, de outro modo, essencial para revelar sua existência ${ }^{34}$. Isso porque as

\footnotetext{
${ }^{31}$ CARNELUTTI, 2006, p. 86.

${ }^{32}$ Expressão empregada por Francesco Carnelutti (CARNELUTTI, 2006, p. 85).

${ }_{33}^{33}$ ALVIM, 2012, p. 3.

${ }^{34}$ CARNELUTTI, 2006, p. 85.
} 
relações são aspectos da realidade estaticamente considerada ${ }^{35}$, algo externo ao indivíduo. Relações de complementariedade, como o interesse, não são perceptíveis pelos sentidos, mas são deduzíveis pela razão. Por serem relações intelectivas, são objeto de um juízo, mas não se confundem com o próprio juízo ${ }^{36}$. Caso ficassem encerrados no âmago dos indivíduos, argumenta Francesco Carnelutti, dificilmente haveria guerras, eis que os homens não se poriam em um estado de guerra apenas por conta de um dissídio de opiniões $^{37}$.

Os interesses, assim, resultam, ou são objeto, desse juízo a respeito da realidade. Nem sempre esse juízo é do próprio sujeito do interesse. Com base no conhecimento construído e compartilhado, concebe-se a existência de interesses que pertençam ao outro. Em razão do que se conhece a respeito do funcionamento do organismo humano, sabe-se que todos rotineiramente têm interesse nos alimentos. O fato de uma pessoa encontrar-se desprovida de consciência, estando também desprovida de sensações e pensamentos, como em um estado de coma, não significa que não possua o interesse de alimentar-se. Reconhecendo-se tal interesse, por meio de normas jurídicas, atribui-se a terceiro o dever de manifestar esse interesse, tomando as providências pertinentes a manter tal sujeito alimentado ${ }^{38}$.

Diante da amplitude de usos e de conteúdos atribuídos ao termo interesse, adota-se, assim, essa noção de relação de complementariedade entre sujeito e objeto na qual aquele experimenta uma vantagem proporcionada por este resultante da satisfação de uma necessidade do sujeito em função da utilidade do objeto, revelando-se tal necessidade, utilidade e relação de complementariedade por um juízo, seja do próprio sujeito, seja de outrem.

\subsection{RELAÇÃO ENTRE INTERESSES}

\footnotetext{
${ }^{35}$ Segundo Francesco Carnelutti existem relações estáticas e dinâmicas. As primeiras são entre entes de uma situação, entendida como o resultado da consideração estática de um aspecto da realidade no espaço (como uma fotografia). As últimas são entre as situações de um fato, entendido como o resultado da consideração dinâmica de um aspecto da realidade no espaço e no tempo (como um filme). O interesse seria uma relação da primeira espécie. CARNELUTTI, 2006, pp. 53/54.

${ }^{36}$ CARNELUTTI, 2006, pp. 60 e 85.

${ }^{37}$ CARNELUTTI, 2006, p. 85.

${ }^{38}$ Os institutos da curatela e da tutela são previstos de forma a tornar terceiro encarregado dos cuidados referentes ao incapaz tutelado ou curatelado.
} 
Maior relevância se dá aos interesses ao se observar sua aptidão de estabelecer relações entre si. Se o interesse propriamente dito é uma relação entre dois elementos distintos, um sujeito e um objeto, ou seja, uma relação heterogênea ${ }^{39}$, a relação formada por interesses elementos da mesma categoria - é homogênea. Francesco Carnelutti classifica as primeiras de relações de primeiro grau e as segundas de relações de segundo grau ${ }^{40}$. Isso não quer dizer, no entanto, que alguma relação sempre se faça presente, sendo plenamente possível uns serem indiferentes aos outros.

Fora dessas situações de indiferença, os interesses interagem das mais variadas formas, ora complementando-se, ora se contrapondo ${ }^{41}$. Nas relações em que há complementariedade, ocorre solidariedade de interesses. Havendo a contraposição, surge o conflito de interesses $^{42}$. Ambas espécies de relações são relevantes para a vida em sociedade, aproximando os indivíduos seja para se beneficiarem das vantagens proporcionadas pela solidariedade de interesses, seja para estabelecerem fóruns e mecanismos para a resolução dos conflitos, evitando-se o uso da violência.

$\mathrm{Na}$ natureza, relações entre interesses de indivíduos de espécies distintas levam-nos a diferentes interações, que estão compreendidas no objeto de estudo do ramo da Biologia chamado Ecologia. Um dos principais focos do exame reside nos efeitos que as interações causam para os indivíduos envolvidos. A esse respeito, observa-se que podem ser neutras, benéficas ou prejudiciais, estabelecendo-se interações com todas as combinações possíveis de efeitos para cada um dos indivíduos. Considera-se benéfica a interação se favorecer seus

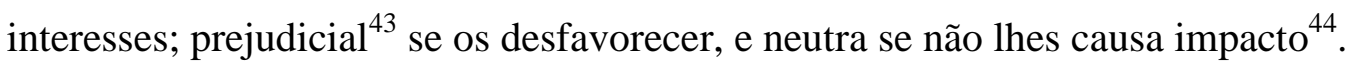

\footnotetext{
${ }^{39}$ Exceto se o objeto do interesse for uma pessoa, hipótese em que se está diante de uma relação homogênea. ${ }^{40}$ CARNELUTTI, 2006, p. 60.

41 A pluralidade de relações entre interesses também é notada por Vincenzo Vigoriti: "La gamma delle relazioni possibili vede ai due estremi, da um lato, l'indifferenza fra gli interessi (per cui Il soddisfacimento di una aspirazione non tocca nè pregiudica il soddisfacimento dell'atra) e, dall'atro, il conflitto fra gli interessi (per cui soddisfacimento di una aspirazione impedisce e pregiudica il soddisfacimento dell'atra). Fra questi due estremi le combinazioni sone le più varie". (Interessi collettivi e processo, Milão, Giuffrè, 1973, p. 18 apud MANCUSO, 2004, p. 21).

${ }^{42}$ Segundo Diogo de Figueiredo Moreira Neto: "Dois interesses, ou mais, podem coincidir sobre o mesmo bem. Se não se excluem, temos, na hipótese, uma relação de coordenação, mas se antagônicos, tem-se instaurada uma relação de confrontação, ou, como é mais conhecida, de conflito." (MOREIRA NETO, Diogo de Figueiredo. Curso de Direito Administrativo: parte introdutória, parte geral e parte especial. 15. ed., revista, refundida e atualizada. Rio de Janeiro: Forense, 2009, p. 11).

${ }^{43} \mathrm{O}$ emprego do termo prejudicial nesse caso é sujeito a críticas na medida em que essas interações podem representar um benefício para a espécie no que toca à seleção de indivíduos melhor adaptados para enfrentarem essas situações, transmitindo essas suas características para seus herdeiros. ODUM Eugene P. Fundamentos de Ecologia. 6. ed. Lisboa: Fundação Calouste Gulbenkian, 2004, p. 342.

${ }^{44}$ ODUM, 2004, pp. 338/339.
} 
É possível identificar nove tipos de relação com base nos efeitos proporcionados para os entes que a estabelecem, em três das quais havendo uma relação e complementariedade de interesses, uma em que há indiferença e cinco em que se estabelece conflito. No neutralismo, nenhum indivíduo afeta o outro, marcando-se pela indiferença. A complementariedade se faz presente no comensalismo, em que uma espécie se beneficia da outra sem causar a esta efeitos positivos ou negativos, e no mutualismo, no qual ambas as espécies são beneficiadas, o que pode ocorrer sem que isso seja imprescindível para a manutenção da vida dos indivíduos envolvidos, a chamada protocooperação, ou de forma obrigatória para sua sobrevivência, ao que se denomina simbiose. O conflito se estabelece se a interação for prejudicial para todos, o que se dá na competição, que pode ser direta ou indireta; se for prejudicial para um e neutra para o outro, no caso do amensalismo; ou ainda se apesar de prejudicial para um, for benéfica ao outro, o que ocorre no parasitismo e na predação.

Interações de ambas as naturezas representaram um relevante papel na evolução das espécies. Enquanto os conflitos desencadeiam o processo de seleção natural resultando na continuidade genética de indivíduos com características que lhes propiciem maiores probabilidades de prevalecerem ou de evitarem conflitos de forma a tornar sua espécie melhor adaptada ao meio, as relações de complementariedade reforçam a sobrevivência das espécies que entre si interagem positivamente ${ }^{45}$.

Partindo dessas interações gerais entre seres vivos, observa-se que também as mais complexas interações entre seres humanos caracterizam solidariedade ou conflito de interesses $^{46}$. Jean-Jacques Rousseau já identificava nos primórdios da humanidade a percepção do homem a respeito da solidariedade e do conflito de seus interesses com os do próximo, a eles se associando, por exemplo, para caçar presas maiores e com eles

\footnotetext{
${ }^{45}$ ODUM, 2004, 340 e 366.

46 "Os humanos são os mais sociais de todos os animais. Nossas sociedades são sustentadas por regras de especialização entre os membros da sociedade, a interdependência prevalecendo sobre a especialização, e a cooperação que a interdependência demanda. No entanto, os humanos são também competitivos, podendo chegar até o ponto da violência, dentro dessa estrutura de suporte mútuo. Nossa vida social equilibra tendências contrastantes em direção à ajuda mútua e ao conflito. Algumas populações de animais apresentam muito da complexidade das sociedades humanas. Os insetos sociais - formigas, abelhas, vespas e térmitas são notáveis por sua divisão de trabalho e coordenação comportamental entre os indivíduos numa colônia ou ninho. Sutilezas semelhantes de interação social, incluindo a especialização de papéis e comportamento altruísta, estão sendo descobertas progressivamente em outros animais, especialmente mamíferos e aves." RICKLEFS, Robert E. A Economia da Natureza. 6 ed. Rio de Janeiro: Guanabara Koogan, 2010, p. 162.
} 
competindo no que toca à caça de animais menores, incapazes de prover alimentos a $\operatorname{todos}^{47}$.

Apesar de até agora ter-se considerado apenas essa relação de interesses entre sujeitos distintos, há de se notar que podem ocorrer entre interesses de um único sujeito, dado que cada indivíduo constitui um centro de inúmeras necessidades.

Ponderando-se acerca das relações de solidariedade, nota-se que algumas necessidades somente se satisfazem caso outras sejam atendidas previamente, ou seja, o atendimento de certas necessidades facilita ou até mesmo se mostra como uma condição sine qua non para a satisfação de outras. Por tal razão, afirma Francesco Carnelutti que antes de ser uma posição favorável a uma necessidade, o interesse pode ser uma posição favorável a outro interesse $^{48}$. Distinguem-se, dessa forma, os interesses instrumentais ou imediatos dos interesses finais ou mediatos.

Pode acontecer que um bem sirva apenas indiretamente para a satisfação de uma necessidade. A posse de pecúnia não serve diretamente para saciar a fome, mas permite ao seu possuidor adquirir o alimento de que, ao final, necessita. Nesse caso, essa situação intermediária constituiria um interesse mediato do qual derivaria o interesse imediato e o atendimento da necessidade em questão.

Daí decorre que as noções de necessidade e interesse são relativas, pois, no mais das vezes, caracterizam elos de uma corrente unida por uma função de meio e fim, de modo que um interesse pode também vir a representar uma necessidade. Conforme afirmado, as necessidades ligam-se a alguma finalidade, sendo certo que pode ser ela o atendimento de

\footnotetext{
47 "Ensinando-lhe a experiência ser o amor ao bem-estar o único móvel das ações humanas, encontrou-se em situação de distinguir as situações raras em que o interesse comum poderia fazê-lo contar com a assistência de seus semelhantes e aquelas, mais raras ainda, em que a concorrência deveria fazer com que desconfiasse deles. No primeiro caso, unia-se a eles em bandos ou, quando muito, em qualquer tipo de associação livre, que não obrigava ninguém, e só durava quanto a necessidade passageira que a reunia. No segundo caso, cada um procurava obter vantagens do melhor modo, seja abertamente, se acreditava poder assim agir, seja por habilidade e sutileza, caso se sentisse mais fraco.

Eis como puderam os homens insensivelmente adquirir certa ideia grosseira dos compromissos mútuos e da vantagem de respeitá-los, mas somente tanto quanto poderia exigi-lo o interesse presente e evidente, posto que para eles não existia a providência e, longe de se preocuparem com um futuro distante, não pensavam nem mesmo no dia de amanhã. Se era caso de agarrar um veado, cada um sentia que para tanto devia ficar no seu lugar [cumprir o seu papel], mas, se uma lebre passava ao alcance de um deles, não há dúvida de que eles a perseguia sem escrúpulos e, tendo alcançado a sua presa, pouco se lhe dava faltar a dos companheiros" (RICKLEFS, 2010, p. 203).

${ }^{48}$ RICKLEFS, 2010, p. 203.
} 
outro interesse. Nessa linha, considera-se que o interesse imediato constitui uma necessidade com relação ao interesse mediato. Se a posse do alimento caracteriza o interesse imediato no tocante à carência alimentar, ao mesmo tempo também configura uma necessidade no que se refere à posse do dinheiro para comprá-1o ${ }^{49}$. O dinheiro é capaz de suprir a necessidade de aquisição de alimento, o qual, por sua vez, é capaz de satisfazer a necessidade do sujeito de alimentar-se.

Essa relação de meio e fim entre interesses pode se dar em função da antecipação de necessidades por parte do sujeito. A aquisição de poupança pode ser vista, assim, como um interesse instrumental em vista do atendimento de um interesse final relacionado a uma necessidade futura.

Em outras hipóteses, o bem objeto do interesse é dotado de utilidade de tal natureza que é capaz de satisfazer diversas necessidades, de forma que a satisfação de uma importe a satisfação de outras. Essa circunstância, aliás, como se observará adiante, é vista como um critério de distinção entre interesses individuais e coletivos, na medida em que aludidas necessidades pertençam a sujeitos distintos.

As relações de solidariedade podem se dar como resultado da coordenação de esforços para a satisfação de diferentes necessidades. Em uma caverna com duas entradas, enquanto um sujeito vigia a primeira, outro vigia a segunda de forma a satisfazer a necessidade de ambos de protegerem-se de ameaças externas. Estaria-se, nesse exemplo, diante de uma forma de mutualismo. De outra forma, o atendimento de uma necessidade de um sujeito pode proporcionar um benefício para o outro sem que este nada ofereça àquele. Um dos homens que compartilha a caverna e que, visando proteger-se do frio, venha a acender uma fogueira também beneficiará o outro, que experimentará a mesma vantagem sem nada ter contribuído para ela. O calor do fogo aproveita a todos que se encontrem ao seu redor. Nota-se que as necessidades satisfeitas podem não ter a mesma natureza. Caso o primeiro sujeito fosse cego, o único benefício por ele experimentado seria o calor, enquanto o segundo também tiraria proveito da luz proveniente da fogueira. Trata-se, pois, nesse exemplo de uma espécie de comensalismo.

${ }^{49}$ CARNELUTTI, 2000, p. 56. 
Por mais que haja interesses que caracterizam meio para o desenvolvimento de outros e que existam interesses que representam a satisfação conjunta de uma pluralidade de necessidades, nem sempre há uma relação de compatibilidade ou consistência entre necessidades ou entre interesses.

Isso porque o conceito de necessidades é amplo, abrangendo não só aquelas situadas no plano material, mas também as no plano moral ou espiritual. Os interesses estão ligados a toda vastidão das necessidades humanas. Nesse quadro, observa Fábio Nusdeo que as necessidades humanas tendem a multiplicar-se ao infinito, não sendo equivocado tratá-las como ilimitadas $^{50}$. Tal constatação independe do grau de riqueza do sujeito, eis que mesmo aqueles indivíduos que possuem suntuoso patrimônio continuamente perseguem a satisfação de novas necessidades materiais. Para eles, em última análise, a acumulação de poupança passa a representar uma necessidade autônoma, desvencilhando-se de necessidades futuras antecipadas ${ }^{51}$.

Se por um lado as necessidades humanas são infinitas, por outro os bens aptos a satisfazêlas são limitados, de modo a que não possam ser empregados para atendê-las todas simultaneamente. O conceito de Economia está relacionado a essas duas observações, a saber: "a) as necessidades, além de serem em grande número, expandem-se indefinidamente; b) os recursos para o seu atendimento são, em maior ou menor grau, limitados, finitos em uma palavra, escassos" 52.

A atividade econômica, objeto de estudo da Economia, é aquela empregada para a "escolha dos recursos para o atendimento das necessidades humanas", ou seja, "a administração da escassez" 53 . A economia, enquanto ciência social, ocupa-se de estudar tal fenômeno na esfera social, sem se preocupar com a sua dimensão individual. Nesse contexto, os bens que são ao mesmo tempo úteis e escassos são considerados bens econômicos, em contraposição aos chamados bens livres, que são aqueles que em certas circunstâncias se apresentam com tamanha abundância que não aparentam ser escassos, de modo a

\footnotetext{
${ }^{50}$ NUSDEO, 1997, p. 31.

${ }^{51}$ Segundo Francesco Carnelutti, nisso reside o fundamento da avareza. CARNELUTTI, 2006, p. 86.

${ }^{52}$ NUSDEO, 1997, p. 31.

${ }^{53}$ NUSDEO, 1997, p. 31.
} 
escaparem do circuito econômico ${ }^{54}$. Quanto maior a escassez e a utilidade de um bem, maior será o seu valor econômico 55 .

Estabelece-se conflito de interesses se "a situação favorável ao atendimento de uma necessidade excluir a situação favorável à satisfação de uma necessidade distinta" ${ }^{56}$, de tal forma que a prevalência de um interesse signifique o detrimento de outro. Esse choque pode perfazer o embate entre interesses das mais diversas naturezas.

Em razão de limitações de diversas ordens, tais como patrimoniais, a aquisição de um bem por um sujeito pode levar à impossibilidade de obtenção de outro, configurando-se um conflito de interesses individuais, nesse caso, intrassubjetivo. A disponibilidade de um único bem almejado por dois sujeitos caracteriza conflito individual, nesse caso intersubjetivo. Do mesmo modo, a manutenção de um bem imóvel para fins habitacionais por um indivíduo contrastará com a utilização do mesmo para a abertura de uma avenida, caso em que se estará diante de um conflito entre um interesse individual e um interesse coletivo. Por fim, também pode se conceber o conflito de interesses supraindividuais, como, por exemplo, nas hipóteses de insuficiência orçamentária do Estado para a realização de diferentes obras públicas nas áreas da saúde e da educação.

Diversas teorias foram desenvolvidas para explicar a origem dos conflitos, sob variados enfoques $^{57}$. As chamadas teorias das características individuais ${ }^{58}$ analisam os conflitos pondo em perspectiva questões relacionadas a atributos individuais dos sujeitos, como

\footnotetext{
${ }^{54}$ NUSDEO, 1997, p. 37.

${ }^{55}$ Em associação às noções de utilidade e escassez, surge o conceito de valor, de fulcral importância para a Economia. Abrange duas variantes não-excludentes: o valor de uso e o valor de troca. $\mathrm{O}$ primeiro diz respeito à utilidade especifica que o bem apresenta para um determinado indivíduo ou pequeno grupo de indivíduos, dentro das circunstâncias em que se encontram, e levando em consideração questões subjetivas, como, por exemplo, o valor de estimação. O segundo corresponde à dimensão social do valor, despido de subjetivismos de forma a relevar o que represente para indivíduos em particular, tomado por uma projeção objetiva e impessoal conforme avaliado socialmente. Ele resulta do consenso presumido entre os indivíduos a respeito da avaliação dos bens econômicos em razão de sua utilidade e abundância, dando bases para o intercâmbio de aludidos recursos. Sob essa acepção, tem-se o valor de troca como valor utilidade, base de uma das principais teorias econômicas. Por consequência, quanto maior a escassez e a utilidade de um bem, maior será o seu valor. Esse é o conceito de valor defendido pelos adeptos da teoria do valor utilidade, que historicamente se contrapõe à teoria do valor trabalho, de acordo com a qual "a fonte de todo o fenômeno valorativo no mundo está no trabalho", desde que seja "socialmente relevante ou útil, destinado ao atendimento das necessidades humanas" (NUSDEO, 1997, p. 62). Sob essa perspectiva, o valor de um bem corresponderia ao trabalho socialmente relevante nele incorporado (ibidem).

${ }^{56}$ CARNELUTTI, 2000, pp. 60/61.

${ }^{57}$ RISKIN, Leonard L. et al. Dispute Resolution and Lawyers. 4 ed. St. Paul: West Publishing, 2009, pp. $3 / 5$.

${ }^{58}$ Individual characteristics theories (RISKIN, 2009, p. 3).
} 
necessidades insatisfeitas ou ameaças à identidade individual ou social, ou de valor próprio. As teorias dos processos sociais ${ }^{59}$ partem das mesmas bases das teorias das características individuais, mas dão ênfase à sua manifestação na esfera dos relacionamentos entre os sujeitos, entendendo os conflitos como o resultado da competição por recursos. Por fim, as teorias das estruturas sociais analisam os conflitos com base nas estruturas institucionalizadas que organizam a sociedade em seus diferentes períodos históricos, atribuindo sua origem às disparidades de poder e influência entre os grupos sociais, como as que se estabelecem entre gêneros, e raças, ou entre a burguesia e o proletariado, conforme teoria de Karl Marx. Esses três grupos de teorias não são entre si excludentes, oferecendo perspectivas complementares para a análise dos conflitos, por mais que em situações específicas as causas relacionadas a uma possam ser mais aparentes do que as das outras.

Conflitos experimentados meramente no foro interno de um indivíduo - os conflitos intrassubjetivos - não são, no mais das vezes, de grande importância sob a ótica do Direito $^{60}$, vez que a sua resolução caberá ao indivíduo que os hospeda, priorizando aquela necessidade que subjetivamente julgar de maior relevância em detrimento da outra, assim formando sua vontade. Maior repercussão desperta o conflito que se estabelece entre interesses de diferentes sujeitos, e estes não são capazes de resolvê-los por meio de uma solução pacífica ${ }^{61}$, surgindo o risco da violência.

Os conflitos de interesses podem transparecer de diversas formas, nem sempre tidas como socialmente indesejadas ${ }^{62}$. Interações de competição se formam também entre seres humanos, não sendo uma exclusividade dos demais seres vivos. Fenômenos dessa espécie se verificam na disputa por bens e serviços, como a dos dois sujeitos famintos pelo único alimento disponível, mas também no seu fornecimento. A concorrência entre fornecedores e prestadores de serviços é considerada de tamanha importância para o mercado que recebe proteção constitucional, sendo a livre concorrência considerada um dos princípios da

\footnotetext{
${ }^{59}$ Social Process Theories (RISKIN, 2009, p. 3).

${ }^{60}$ CARNELUTTI, 2000, p. 61.

${ }^{61}$ Carnelutti afirma que à margem do Direito, a solução pacífica poderá ser uma solução moral, se as partes em conflito encontrarem-na no seu espírito; contratual, se baseada no medo de uma das partes com relação à outra, ou arbitral, se decorrente do medo em relação à força de terceiro (CARNELUTTI, 2000, p. 62).

${ }^{62}$ RISKINS, 2009, p. 6.
} 
ordem econômica pela Constituição da República de $1988^{63}$. Também é incentivada e, de forma geral, exigida nas contratações efetuadas pelo Poder Público, por meio de licitação pública $^{64}$ ou concurso público ${ }^{65}$.

Ainda em comparação com as interações entre espécies observadas na natureza, observa-se que no vasto universo de interações entre seres humanos ou as entidades por eles formadas, algumas podem conter características semelhantes às do amensalismo. A poluição, em todas as suas formas (e.g., atmosférica, sonora, por efluentes líquidos ou resíduos sólidos), produzida pela atividade humana no mais das vezes apresenta certo grau de nocividade àqueles que se encontram no entorno ${ }^{66}$.

Reconhecendo a inevitabilidade dos conflitos de interesses e a diversidade de efeitos que podem gerar, nem todos negativos, discorre Diogo de Figueiredo Moreira Neto:

A harmonia social é uma situação de equilíbrio instável. Os conflitos de interesses são inevitáveis e devem ser considerados sob todos os seus aspectos. Existirão sempre conflitos, em quaisquer modalidades de relações humanas, mas nem todos repercutirão sobre o grupo social e, ainda assim, nem sempre nele se refletirão negativamente, pois muitas divergências podem apresentar um potencial criativo e aperfeiçoador. Sobreviverão, porém, inevitavelmente e em maior número, aqueles conflitos que perturbam a harmonia social e que introduzem um potencial destrutivo e corruptor, sendo esses, pois, os que deverão ser evitados e, uma vez manifestados, solucionados ${ }^{67}$.

\footnotetext{
${ }^{63}$ Artigo 170, inciso IV. A Constituição de 1988 protege a concorrência por meio de outras disposições, como, por exemplo, por meio da previsão de repressão ao abuso do poder econômico (artigo 173, §4 ${ }^{\circ}$ ). ${ }_{65}^{64}$ Artigo 37, inciso XXI da Constituição da República de 1988 e Lei no 8.666, de 21 de junho de 1993.

${ }^{65}$ Artigo 37, inciso II, da Constituição da República de 1988.

${ }^{66}$ Ao impactar os indivíduos do entorno a poluição causará a estes um prejuízo, correspondente a um custo. Caso esse custo não seja compensado pelo agente poluidor, ficando, assim, externo aos mecanismos de mercado, constituirá uma externalidade negativa (NUSDEO, 1997, pp. 176/180). O princípio de direito ambiental do poluidor-pagador visa internalizar tal custo ao agente poluidor (NUSDEO, 1997, pp. 185 e 428/430).

${ }^{67}$ MOREIRA NETO, 2009, p. 10.
} 
A existência de conflito não significa que o mesmo se traduzirá em uma disputa efetiva entre os envolvidos ${ }^{68}$. Poderá ser alcançada uma resolução ou o conflito poderá permanecer latente, com o risco de em acarretar algum grau de corrosão social. Isso porque, no mais das vezes, as relações entre os indivíduos não se resumem à interação entre dois interesses isolados. Não é incomum que haja um conjunto de interesses envolvidos, que levam os sujeitos a ponderar como agir perante o outro, sopesando os interesses em conflito e em complementariedade.

Dentre as formas de resolução pacífica ${ }^{69}$, pode despontar a composição econômica dos interesses, baseada em uma avaliação da sua utilidade feita pelos indivíduos em conflito, de tal maneira que um deles, deixando prevalecer o do outro, renuncia ao seu por considerá-lo não tão vantajoso a ponto de compensar o eventual mal a ser causado pela $\operatorname{disputa}^{70}$. Essa decisão pode ter como fundamento o temor da força do outro ou de terceiro, bem como os possíveis efeitos danosos que o uso da violência pode causar para os outros interesses do renunciante. A composição econômica do conflito consubstancia-se na posse, exercida por um e tolerada pelos outros ${ }^{71}$.

O valor de troca dos bens constitui um critério facilitador da resolução econômica dos conflitos, permitindo que um sujeito que possua um bem em abundância o entregue a outro sujeito que dele necessite, recebendo em troca algo que constitua objeto de uma de suas necessidades, sobretudo dinheiro, com valor econômico correspondente. Nesse caso, o conflito é resolvido na medida em que o possuidor do bem julgue que o seu interesse em

\footnotetext{
${ }^{68}$ Fato é que conflitos existem rotineiramente. Uma disputa é uma forma de externalização desses conflitos. "Conflict may be defined simply as a clash o interests or aspirations, actual or perceived. Disputes are immediate manifestations of conflict, and arise when people take actions based on this actual or perceived clash." (RISKIN, 2009, p. 3).

${ }^{69}$ Diogo de Figueiredo Moreira Neto classifica em três grupos as formas de resolução de conflitos de interesses, levando à solução ética, transacional ou de autoridade. A solução ética importa que um dos sujeitos abra mão do seu interesse em favor do outro e da paz. A transacional caracteriza-se pelo consentimento dos sujeitos em conflito, podendo ser por acordo, se chegarem a bom termo por negociações diretas; mediação, se a solução conciliatória for alcançada pelas próprias partes com a assistência de um terceiro neutro; ou por arbitramento, se as partes concordarem em submeter o conflito à decisão de um terceiro. A solução de autoridade implica a imposição de uma decisão de terceiro, englobando a solução arbitrária, se aludida decisão for proferida de forma livre pelo terceiro sem qualquer parâmetro prefixado, ou jurídica, se a decisão decorrer da aplicação de uma norma jurídica. (MOREIRA NETO, 2009, p. 11).

70 "Este tipo de composição espontânea tem sempre, em última análise, o seu fundamento num cálculo de utilidade. Aquele dentre ambos que deixa prevalecer o interesse do outro, procede assim para evitar o pior, donde resulta que a solução do conflito intersubjetivo se obtém por meio da solução de um conflito individual. Estamos ainda aqui no terreno da economia, a qual, até um certo ponto, tem em si os remédios para curar os seus males." (CARNELUTTI, 2006, pp. 92/93).

${ }^{71}$ CARNELUTTI, 2006, p. 93.
} 
obter aquele valor seja para ele mais relevante do que manter aquilo que já possuía em abundância. Pela outra perspectiva, a parte que recebeu o bem o tinha em maior relevância do que o valor entregue em troca ${ }^{72}$.

De outro modo, pode advir uma composição ética como forma de apaziguar o conflito, baseada na observância de uma regra ética, ou moral. Tais regras têm origem na consciência do indivíduo e são ditadas caso a caso visando alcançar valores como a justiça, a caridade e a honestidade. Aqui, a resolução amigável do conflito igualmente deriva da ponderação a respeito dos interesses a serem privilegiados. A diferença é que a necessidade a que se faz prevalecer diz respeito aos valores éticos e morais pertencentes ao indivíduo envolvido no conflito. Antes mesmo de dizer respeito ao comportamento intersubjetivo, as regras éticas são intrassubjetivas, influenciando a manifestação dos interesses de modo a reprimir aqueles que não se encontrem em conformidade com o que se entenda certo ${ }^{73}$.

Muitas circunstâncias influenciam a resolução, ou o prolongamento, dos conflitos. Dentre essas variáveis, a preexistência de um relacionamento ou a expectativa de um relacionamento futuro entre as partes pode representar um fator a torná-las mais suscetíveis a soluções flexíveis, seja como retribuição por fatos passados ou para fortalecer o seu elo almejando o futuro. De modo diverso, podem em outros casos, constituir óbice para a solução consensual na medida em que o histórico entre as partes não seja harmonioso. Relações familiares ilustram essas constatações, por ora os laços aproximando as partes ${ }^{74}$, por ora as afastando e dificultando a resolução de conflitos aparentemente simples.

Nem sempre uma solução consensual, com a qual as partes restem minimamente satisfeitas, é alcançada. Por conta de desigualdades das mais variadas ordens entre as partes, uma delas pode vir a impor sua vontade à outra de tal maneira que acabe gerando insatisfação e injustiça, reprimindo o conflito ao invés de solucioná-lo, com o risco de

\footnotetext{
${ }^{72}$ A obtenção de informações a respeito dos interesses da outra parte no conflito é considerada uma das principais etapas para o sucesso de negociações, permitindo aos agentes envolvidos adotarem uma postura colaborativa de forma a mudar o foco de atenção das posições inconciliáveis mantidas pelas partes para aqueles interesses compartilhados ou para outros bens que possam satisfazer as necessidades subjacentes (SHELL, G. Richard. Bargaining for Advantage. 2. ed. New York: Penguin, 2006, pp. 78/79, 86/87 e 149/151).

${ }^{73}$ Para Francesco Carnelutti, a regra ética levam à formação de relações éticas entre os homens, que se estabelecem ao lado das relações econômicas e das relações políticas, as últimas construídas tendo por elo a solidariedade de interesses a formar os interesses coletivos (CARNELUTTI, 2006, pp. 90 e 96).

${ }^{74} \mathrm{O}$ conflito entre dois sujeitos famintos, pai e filho, tenderia a se resolver em favor do filho pois ao pai interessa a vida do filho (CARNELUTTI, 2006, p. 91).
} 
provocar o esgarçamento do tecido social. Assim é que as regras morais podem prevenir uma solução puramente econômica do conflito. Mesmo que para uma das partes seja economicamente mais vantajoso renunciar ao seu interesse em conflito ou aceitar uma dada solução que não o atenda plenamente - sobretudo considerando os custos e riscos envolvidos na disputa - pode ela vir a rechaçar tal resolução consensual por, no seu entender, ser injusta, assim contrariando seus valores morais. Sacrifica-se o interesse econômico para privilegiar o interesse moral.

Segundo Francesco Carnelutti, o Direito, tendo em vista a diferença e os diversos graus de sensibilidade da consciência dos diversos seres humanos, justamente tem como função impor a ética, conforme definida socialmente, como critério de solução de $\operatorname{conflitos}^{75}$. Ao ser formulada e imposta pelo Direito, observa-se, entretanto, que a regra ética perde a sua natureza, pois deixa de ser cumprida exclusivamente em respeito a uma determinação da consciência para ser respeitada em função da imposição social ${ }^{76}$.

A existência do Direito, contudo, não significa que as partes sempre dele se socorrerão para resolverem seus conflitos. Pode o Direito deixar de ser observado e exercido, por um lado em razão de óbices tais como o desconhecimento das partes, os custos envolvidos no processo de aplicação coercitiva da regra jurídica ${ }^{77}$, ou mesmo a deficiência ou ineficiência

\footnotetext{
${ }^{75}$ CARNELUTTI, 2006, p. 98.

${ }^{76}$ Para Vicente Ráo Moral e Direito tem em comum o fundamento ético e o caráter obrigatório de suas normas. $\mathrm{O}$ que os distingue é a natureza das sanções, enquanto constituem sanções da norma moral o remorso ou a desconsideração social, o desrespeito à norma jurídica tem a potencialidade de ensejar a coação material praticada pelo Estado. Ademais, o foco principal da Moral residiria na esfera interna do indivíduo, na formação de sua vontade, e o do Direito, na externalização da vontade, nos atos humanos inseridos na realidade física, por mais que a cada um também seja relevante a outra esfera. Nota-se, ainda, que normas jurídicas tem origem em normas morais, havendo uma tendência de transformação destas naquelas. (RÁO, Vicente. O Direito e a Vida dos Direitos. 5. ed. anotada e atualizada por Ovídio Rocha Barros Sandoval. São Paulo: Revista dos Tribunais, 1999, pp. 71/77).

${ }^{77}$ Jhering identifica essas situações em que o sujeito, frente a um conflito, deve decidir qual caminho trilhar. "Violado um direito, o titular defronta-se com uma indagação: deve defender seu direito, resistir ao agressor, em outras palavras, deve lutar, ou deve abandonar o direito para escapar da luta? A decisão a esse respeito só a ele pertence.

Seja qual for essa decisão, a mesma sempre envolve um sacrifício: num caso o direito é sacrificado a favor da paz, noutro a paz a favor do direito. Dessa forma a indagação adquire novos contornos: qual o sacrifício mais suportável, face às características do caso concreto e da pessoa nele envolvida? O rico, para preservar a paz, poderá desistir da quantia em litígio, se a considerar de pouca monta; já para o pobre a mesma quantia poderá ser relativamente vultosa, e por isso preferirá sacrificar a paz para defendê-la. Dessa forma a questão da luta pelo direito se resolveria num simples exercício de matemática, onde se comparariam as vantagens e desvantagens de cada uma das alternativas para chegar a uma solução". Nota, entretanto, que essa não é a prática que se observa no mais das vezes. Mesmo que os custos e dissabores proporcionados pela busca de proteção ao seu direito sejam mais desvantajosos do que o valor do direito tido por violado, ainda há casos que o seu titular busca defender seu direito. Nesses casos, estar-se-ia privilegiando a afirmação da sua própria pessoa e do sentimento de justiça. "O fim compensa os meios. Não é o prosaico interesse pecuniário, mas a
} 
dos institutos e instituições voltados para sua implementação, mas por outro, em razão da própria vontade das partes, que, dentro do seu espaço de liberdade, optem por uma resolução econômica ou ética diferente da propugnada pelo Direito.

Assim, constata-se ser natural o fenômeno das relações entre interesses, seja no que tange às interações entre seres vivos em geral, seja no que diz respeito ao homem, considerado isolada ou socialmente. Essas relações podem ser de solidariedade ou complementariedade, servindo como fator de agregação, ou de conflito, gerando o risco da violência. No que toca ao ser humano, nos planos intrassubjetivo e intersubjetivo, em razão da multiplicidade de interesses concentrados nos sujeitos, tendem as relações entre interesses a ser complexas, reunindo conflitos e complementariedades simultâneas. No plano econômico, os conflitos são resolvidos pacificamente por meio da avaliação individual da utilidade dos interesses envolvidos pelos sujeitos, de modo a sacrificarem em prol do outro aquele que julgarem de menor importância frente às circunstâncias. No plano ético, os conflitos são resolvidos pela aplicação de regras éticas ou morais mantidas pelos sujeitos com base nos valores que orientam a sua consciência. O Direito tem a função de impor regras em conformidade com um dado conjunto de valores como critério de resolução de conflitos, eis que estes nem sempre são adequadamente resolvidos por meio da economia ou da ética individual dos sujeitos em conflito.

Dois temas surgem com base nessas espécies de potenciais relações entre interesses. Em primeiro lugar, por conta da existência dos conflitos de interesse, destaca-se a proteção de interesses pelo Direito, formando os interesses jurídicos. Em segundo lugar, considerando as relações de solidariedade, desponta a distinção entre interesses individuais e coletivos. Aludidos temas serão objetos dos tópicos subsequentes

dor moral da injustiça sofrida que impele a vítima a instaurar o processo". Para o autor a defesa do direito seria um dever do seu titular para consigo mesmo, um imperativo de defesa moral, nada obstante o valor econômico envolvido. (JHERING, Rudolf Von. A Luta Pelo Direito. Tradução e apresentação de Richard Paul Neto. Rio de Janeiro: Rio, 1978, pp. 15/20). 


\section{CAPÍTULO 2. INTERESSE JURÍDICO}

As ações humanas se pautam em interesses. Há inclusive quem entenda que todas as atividades do Homem são interessadas, na medida em que os indivíduos vivam somente em busca da satisfação de necessidades dos mais variados tipos ${ }^{1}$. Uma das premissas do utilitarismo é a de que o homem pauta sua conduta em busca do prazer, da felicidade, de modo que as escolhas por ele feitas no curso de sua vida são precedidas pela avaliação comparativa, nem sempre consciente, entre as diferentes alternativas disponíveis com a eleição daquela que julgar capaz de lhe proporcionar maior satisfação pessoal ${ }^{2}$. Critica-se tal entendimento por ser demasiadamente individualista, reduzindo as ações humanas a ações egoístas, visando sempre o benefício próprio.

Em reação a tais críticas, nota-se que o interesse que move o ser humano não se volta sempre ao seu benefício próprio. Aqui, duas situações se distinguem. Casos há em que a ação individual causa a satisfação de necessidades alheias. Esse efeito, contudo, pode não ser nem intencional nem o motivo preponderante da ação, na medida em que o sujeito pretenda uma vantagem própria, mas reflexamente também proporcione benefício a outrem. Apesar da motivação ser egoísta, o resultado da ação pode ser coletivamente vantajoso.

Em outras hipóteses, todavia, o indivíduo age com abnegação, com sacrifício próprio em favor de um interesse alheio. O que procura não é um benefício seu, por vezes vindo até a experimentar um malefício, mas sim prestigiar uma necessidade alheia, praticando um ato altruísta. Partindo de uma concepção ampla do conceito de interesse, afirma-se que

\footnotetext{
1 "O interesse se anuncia como o móbil do comportamento do homem moderno, não porque ele seja essencialmente egoísta mas porque nada é feito na sociedade se os indivíduos não reconhecerem sua própria vantagem. O cidadão não saberia cumprir seu dever, nem contribuir ao bem público sem encontrar nisto uma satisfação pessoal." (DERANI, Cristiane. Privatização e Serviço Público: as ações do Estado na produção econômica. São Paulo: Max Limonad, 2002, p. 49).

${ }^{2}$ Alf Ross entende não ser possível mensurar e comparar o grau de felicidade proporcionado pela satisfação de diferentes necessidades humanas de forma a inexistir um critério objetivo a indicar qual deve prevalecer. Exceção feita no campo econômico porquanto os diferentes interesses econômicos do mesmo sujeito podem ser expressos monetariamente e, assim, comparados de forma a maximizar a sua satisfação. "A situação verdadeira é que somos movidos por muitas necessidades e considerações diferentes, que se confrontam e lutam num processo irracional de motivação. Estamos submetidos à influência de uma diversidade de padrões de valoração e preferência que se desenvolvem e se estabelecem individual e socialmente." (ROSS, 2003, p. 339).
} 
também os atos altruístas visam um proveito próprio. Não necessariamente seja uma retribuição na forma de gratidão do sujeito beneficiado, ou a construção de uma imagem benevolente perante a sociedade ou o mercado, ou mesmo alguma vantagem concedida pela coletividade, como um benefício fiscal. Claro que essas retribuições ou prêmios podem ser a causa ou o incentivo da ação. Mas, além disso, mesmo aqueles atos completamente anônimos e marcados pelo desprendimento material podem caracterizar uma vantagem para seu autor na medida em que lhe satisfaçam uma necessidade correspondente a um sentimento ou dever moral de ser solidário, nada obstante o que cause tal sentimento ou dever. Sob essa perspectiva, a prática de um ato altruísta também seria interessada por importar a satisfação de uma necessidade própria. O interesse alheio seria visto como instrumental para um interesse próprio de fazer o bem.

Alf Ross entende que atos altruístas também são atos interessados, a diferença é que a necessidade que se procura atender não pertence ao agente. Assim, além dos interesses egoístas há os interesses altruístas, que não se referem a necessidades próprias, mas sim alheias, e que são fundados em sentimentos de simpatia ${ }^{3}$.

Na visão de Alf Ross o interesse não serve de motivação para toda e qualquer ação humana. Dentre aquelas que considera desinteressadas, elenca os reflexos, que ocorrem sem conhecimento e vontade; as ações sugeridas ou persuadidas, decorrentes de impulsos de ação espontâneos transmitidos por meios de persuasão linguísticos e não linguísticos, como, por exemplo a ordem dos pais para que os filhos interrompam certa atividade perigosa; e as atitudes morais, principalmente ao se experimentar a moral como um dever. Para o autor, em nenhum desses casos as ações estariam voltadas à satisfação de alguma necessidade, a alguma vantagem ou utilidade ${ }^{4}$. Não considera, assim, que os efeitos positivos que tais ações proporcionam para os agentes indiquem certo interesse.

Nada obstante se admita ou não a existência de ações desinteressadas, revela-se árdua a tarefa de contestar a multiplicidade de interesses com que lidam os seres humanos diariamente. Considerando esse vasto conjunto de interesses e as relações que entre eles se estabelecem, ao Direito cumpre a função de dar subsídios tanto para a resolução de

\footnotetext{
3 "O interesse altruísta tem caráter indireto: se remete a um interesse direto de outro, ou seja, a um interesse que é experimentado por alguém que não é a própria pessoa como um interesse direto ou um interesse próprio" (ROSS, 2003, p. 411).

${ }^{4}$ ROSS, 2003, pp. 416/417.
} 
conflitos de interesse, quanto para a consecução de interesses complementares ou comuns ${ }^{5}$. Examina-se, no presente tópico, a primeira dessas funções.

\subsection{INTERESSE JURÍDICO}

Considerados no sentido lato, são os interesses dotados de amplo e variável conteúdo axiológico, despidos de valores ético-normativos predefinidos. Dentro do plano da existência-utilidade, os interesses se constroem em relações de complementaridade baseadas em toda sorte de necessidades e tendo por objeto bens das mais variadas espécies $^{6}$.

Diante desse vasto campo de abrangência das relações que podem constituir interesse, não é de se surpreender que nem todos os interesses sejam protegidos pelo Direito ${ }^{7}$. Muitos não são considerados relevantes o suficiente para ser objeto de proteção, de forma a que não sejam exigíveis ou tuteláveis ${ }^{8}$. Mesmo porque, se todos fossem protegidos, nenhum efetivamente o seria, sobretudo em uma situação de conflito em que interesses contrapostos não possam ambos prevalecer de forma simultânea e integral. Se os interesses em sentido lato se associam a toda sorte de valores em função do arbítrio de seus titulares, os interesses jurídicos consubstanciam conteúdo valorativo prefixado na norma, estabelecendo-se no plano ético-normativo como resultado da escolha feita pela autoridade social $^{9}$.

\footnotetext{
${ }^{5} \mathrm{O}$ objeto do presente estudo relaciona-se justamente a certas tentativas de conjugação dessas funções de forma a que a resolução de um conflito de interesses possa ser efetivada de forma a representar também a proteção a outros interesses complementares ou comuns.

${ }^{6}$ MANCUSO, 2004, pp. 21/22.

${ }^{7}$ Segundo Diogo de Figueiredo Moreira Neto: "A convivência numa sociedade civilizada seria impossível sem um mínimo de segurança de seus membros de que certo núcleo fundamental de interesses individuais será invariavelmente respeitado e protegido.

Portanto, ao Estado, como organização juspolítica da sociedade, cabe declarar quais são esses interesses, que devem ser por ele assegurados, uma vez que, para o desempenho dessa missão, ele veio a se tornar historicamente o centro da mais significativa concentração de poder institucionalizado, constituindo-se como um Poder Público e, desse, modo, atuando como fonte de direito". (MOREIRA NETO, 2009, pp. 6/7).

8 "Nem todos os interesses, oriundos da multiplicidade das necessidades que a vida social sugere ou exige dos componentes do grupo, são compreendidos pelo direito. Interesses religiosos, artísticos, científicos, políticos, de cortesia, de amizade, nem sempre correspondem a categorias jurídicas, ou seja, nem sempre estão inseridos no mundo do direito. Assim, o interesse em divulgar determinada fé religiosa, ou em defender determinada corrente literária ou artística ou científica, não são jurídicos. Também não o são os gestos de cortesia como os cumprimentos protocolares e as manifestações de amizade." (MARINS, Victor A. A. Bomfim. Comentários ao Código e Processo Civil, vol. 12: do processo cautelar, arts. 813 a 889. São Paulo: RT, 2000, pp. 42/43).

${ }^{9}$ MANCUSO, 2004, pp. 20/22.
} 
Ressalte-se que a circunstância de um interesse encontrar amparo no Direito não previne que o interesse a ele contraposto também seja juridicamente protegido. Nesses casos extraem-se do ordenamento jurídico critérios para determinar qual o prevalecente, certo que nem todos os interesses jurídicos encontram no ordenamento o mesmo grau de amparo. Constatam-se diferentes níveis de proteção conferidas pelo ordenamento aos titulares de interesses, de forma que o seu reconhecimento não implique sua necessária proteção em toda e qualquer situação.

\subsection{CLASSIFICAÇÃO DOS INTERESSES SOB A ÓTICA JURÍDICA}

Considerando a diferença do tratamento dado pelo ordenamento jurídico, estabelece-se uma classificação dos interesses sob uma ótica tradicional de cunho privado ${ }^{10}$.

Em conformidade com os valores prestigiados pela comunidade em dado momento histórico, há interesses reconhecidos pela ordem jurídica, assumindo a qualidade de interesses juridicamente relevantes, sendo os demais, desimportantes, relegados à categoria de juridicamente irrelevantes. Aqueles se dividem em duas espécies: os desconhecidos e os reconhecidos pelo Direito. Enquanto os juridicamente irrelevantes são aqueles a respeito dos quais a ordem jurídica é indiferente, os desconhecidos constituem interesses cuja satisfação é socialmente indesejada de forma a serem vedados pelo Direito. Os juridicamente reconhecidos, por seu turno, recebendo diferentes graus de proteção, dividem-se em interesses simples e direitos subjetivos.

Sob essa classificação, entende-se por interesse simples aquele de natureza individual que não recebe proteção se considerado em si mesmo, mas que é reconhecido e protegido objetivamente enquanto coincidente com um interesse coletivo tutelado pelo Direito. Trata-se de proteção objetiva pois decorrente de uma norma de direito objetivo, que visa a satisfação do bem comum, mas que acaba indiretamente gerando vantagens individuais. Augustin Gordillo alude ser o interesse simples aquele de que é dotado todo cidadão de

\footnotetext{
${ }^{10}$ A classificação aqui exposta baseia-se em estudo elaborado por José Renato Nalini (NALINI, 1985, pp. 240/250) e antecede a consagração dos interesses difusos e coletivos como institutos jurídicos próprios, merecedores de tutela autônoma.
} 
que a lei seja cumprida ${ }^{11}$. Tradicionalmente ao titular do interesse simples não são disponibilizadas vias de proteção processual, ficando na dependência de que algum legitimado - tipicamente o Estado - atue em benefício do interesse coletivo no qual esteja compreendido $^{12}$.

Rodolfo de Camargo Mancuso manifesta entendimento diverso do que venha a constituir interesse simples, aproximando-o daquilo a que se referiu por interesses juridicamente irrelevantes ${ }^{13}$. Para o autor, interesses simples também seriam conhecidos como interesses de fato ou meros interesses, representando a acepção laica do que venha a ser interesse. Encontrar-se-iam arraigados internamente no agente, na sua esfera psicológica, correspondendo a "uma aspiração a obter uma determinada situação de vantagem, acompanhada da consciência de que tal aspiração não é exigível ou oponível em face de terceiros", como, por exemplo, a aspiração de ter um bilhete de loteria premiado ou de alcançar uma boa classificação em um concurso público ${ }^{14}$. Incluiria também os casos em que a vantagem almejada é mínima ou insignificante ${ }^{15}$. A esse respeito, faz referência ao brocardo de minimis non curat praetor, pelo qual se expressa existir um limite abaixo do qual "os interesses se tornam simplesmente irrelevantes" de forma a não merecerem tutela $^{16}$. Tais interesses teriam por notas características a sua inoponibilidade, a restrição

${ }^{11}$ Apud MANCUSO, 2004, p. 23.

12 "A efetivação de providências de interesse geral tutela, contudo, indiretamente o interesse individual. Assim, a promulgação e execução de preceitos legais, relativos à proibição de ruídos urbanos e de excesso de velocidade dos veículos nas ruas, têm por objetivo imediato resguardar o interesse coletivo. Entretanto, tais medidas, indiretamente e de modo geral, protegem os interesses dos indivíduos integrados no Estadosociedade em que forem considerados.

É direito do Estado-poder, ou de quem faça as suas vezes, estabelecer e obrigar o respeito de providências de tal natureza, sendo que, embora acarretem vantagens aos cidadãos, estes não pode exigi-las, mesmo porque são de utilidade indeterminada dos componentes da sociedade. Temos aí a situação de simples interesse dos administrados em geral" (BANDEIRA DE MELLO, Oswaldo Aranha. Princípios Gerais de Direito Administrativo, vol. I. 2. ed., Rio de Janeiro: Forense, 1979, pp. 227/228).

13 Outros autores compartilham desse entendimento de interesses simples como interesses sem qualquer amparo jurídico (COSTA, 2009, p. 46; MOREIRA NETO, 2009, p. 7).

${ }^{14}$ MANCUSO, Rodolfo de Camargo. Interesses Difusos: Conceito e Colocação no Quadro Geral dos Interesses in Revista de Processo no 55, ano 14, julho-setembro de 1989, p.167.

${ }^{15}$ MANCUSO, 2004, p.22.

${ }^{16}$ Nas palavras do autor: "Mesmo no âmbito da ação judicial esse aspecto é considerado: uma situação de vantagem que se revela nitidamente banal, desprezível, não pode servir de supedâneo para a configuração do interesse processual; caso contrário estar-se-ia admitindo o exercício da ação judicial por mero diletantismo ou capricho, o que não se compadece com a finalidade nem com a dignidade da Justiça" (MANCUSO, 2004, p. 23). Desde já vale notar que tal noção na atual sociedade de massa pode representar um óbice ao acesso à justiça, eis que interesses inexpressivos considerados na esfera individual em muitas situações se reproduzem em tantos sujeitos diferentes de forma a assumir importância na esfera coletiva. Não se nega o afirmado pelo autor, no sentido de que o valor do interesse em disputa possa vir a ser relevante sob a perspectiva processual, como, por exemplo, no que diz respeito à fixação de um teto do valor da causa para que a demanda possa vir a ser ajuizada perante o juizado especial ou a inclusão da repercussão geral como requisito 
dos seus efeitos ao sujeito que os detêm, e a sua indiferença social e jurídica ${ }^{17}$. Nessa visão, por um lado ficam apartados do plano jurídico, não ascendendo ao plano éticonormativo, mas por outro proveem um rico repositório do qual se vale o legislador para inovar na ordem jurídica, em consonância com o que se julga ser o sentimento médio reinante na comunidade em um dado momento, caracterizando insumo do Direito.

Também o direito subjetivo se dividiria em três diferentes subespécies. Direitos subjetivos perfeitos ou interesses incondicionalmente protegidos, que correspondem ao reconhecimento em grau máximo do individualismo com a atribuição de "proteção legal incondicionada a um interesse individual e absoluto" ${ }^{18}$; (ii) direitos subjetivos menos perfeitos, reflexos ou interesses ocasionalmente protegidos, os quais não são diretamente protegidos na esfera individual, mas acabam por ser protegidos em razão da tutela de um interesse geral, aproximando-se dos interesses $\operatorname{simples}^{19}$, e (iii) direitos subjetivos imperfeitos (Affievolitti) ou interesses condicionalmente protegidos, que constituem interesses individuais enfraquecidos pois subordinados e condicionados a um fim de interesse geral $^{20}$.

Uma das formas de expressão dos direitos subjetivos perfeitos se refere àqueles interesses dos indivíduos protegidos em face do Estado, de forma que a este caiba observá-los e darlhes efetividade. O principal intuito da norma da qual decorrem é a sua proteção direta, indiretamente tutelando o bem comum dos membros da coletividade. São os chamados direitos subjetivos públicos do particular em face do Estado, dotando os seus titulares do poder de exigir sejam respeitados e atendidos pelo Poder Público. Dividem-se em direitos subjetivos estrito senso, atinentes aos direitos de liberdade e propriedade; direitos cívicos, concernentes à obtenção da prestação de coisa ou serviço público dentro dos parâmetros

de admissibilidade do recurso extraordinário. Nesses casos, contudo, as exigências a respeito do valor ou relevância do interesse não constituem obstáculo para que uma demanda seja admitida pelo Judiciário.

${ }^{17}$ Interesses Difusos, p. 24.

${ }^{18}$ Hodiernamente reluta-se em reconhecer a existência de direitos absolutos sem que se façam ressalvas a respeito de restrições e exceções, inclusive no tocante ao seu exercício, rejeitando-se o abuso de direito.

19 Os interesses simples são a mera dimensão individual de um interesse geral, enquanto os interesses ocasionalmente protegidos representam algo a mais para seus titulares, para eles proporcionando outra vantagem além daquela compartilhada indistintamente pela coletividade. Oswaldo Aranha Bandeira de Mello considera direito subjetivo apenas aquilo a que se designou de direito subjetivo perfeito, sendo os demais apenas interesses ou direitos imperfeitos (BANDEIRA DE MELLO, 1979, pp. 227/231).

${ }^{20}$ NALINI, 1985, pp. 241/242. 
normativos; e os direitos políticos, alusivos à participação na estrutura de poder estatal na qualidade de cidadão ${ }^{21}$.

Certas normas de direito objetivo visam à realização de interesse coletivo, mas podem vir a atender reflexamente interesses de certos indivíduos de modo mais específico e particular, de certa forma diferenciando-os da generalidade dos cidadãos e assim conferindo a estes indivíduos interesse especial em que sejam observadas. Uma vez que tais interesses não constituem o objetivo primordial da norma, recebem tutela eventual e por isso são conhecidos como interesses ocasionalmente protegidos ${ }^{22}$. Individualmente considerado, o interesse de cada um dos munícipes de que a uma indústria poluidora não seja concedido alvará de funcionamento constitui um interesse simples, pois coincidente com o interesse geral de preservação ambiental. Aquele sujeito que resida próximo do local onde se instalaria a indústria terá, mais do que um interesse simples, um interesse ocasionalmente protegido, pois a ele a poluição traria efeitos mais próximos e diretos, razão pela qual a tutela a ele mais benefícios proporcionaria.

Oswaldo Aranha Bandeira de Mello aduz não se atribuir direito de ação ${ }^{23}$ contra terceiros ou contra o Estado aos titulares de interesses simples ou ocasionalmente protegidos, vez que não constituem direito subjetivo ${ }^{24}$. Assim, mesmo diante da violação da norma de interesse geral que acarrete a violação também do seu interesse, não poderá o interessado obter judicialmente a proteção do seu interesse mediante a determinação de suspensão da atividade lesiva $^{25}$. Poderá lhe restar pretensão indenizatória contra o Estado ou terceiro caso aquela violação efetivamente cause danos a um seu direito. Assim, por exemplo, o proprietário de um posto de combustível não tem legitimidade para propor ação de nunciação de obra nova para embargar a edificação de outro posto de combustível em desacordo com posturas municipais segundo as quais estabelecimentos dessa espécie só possam ser construídos se observado um raio mínimo de distância de outros estabelecimentos congêneres, escolas e hospitais ${ }^{26}$. Excepcionalmente, contudo, desde que

\footnotetext{
${ }^{21}$ BANDEIRA DE MELLO, 1979, p. 228. NALINI, 1985, p. 245.

22 BANDEIRA DE MELLO, 1979, pp. 228/229.

${ }^{23}$ Aqui considerado como direito de obter um provimento jurisdicional favorável.

${ }^{24}$ Victor A. A. Bomfim Marins alude à existência de interesses que encontram correspondência no direito objetivo, mas que o ordenamento não assegura o gozo ao seu titular de forma a não encontrarem-se envoltos por um direito subjetivo (MARINS, 2000, p. 47).

${ }^{25}$ Nota-se, desde já, que essa posição veio a ser combatida na doutrina antes do reconhecimento jurídico dos interesses difusos e coletivos. Referido assunto será melhor abordado mais adiante.

26 "NUNCIAÇÃO DE OBRA NOVA. Posto de gasolina. Legitimidade ativa. Postura municipal.
} 
a lei o faça expressamente, se admite que particulares defendam seus interesses não como um direito subjetivo, mas na tutela do próprio direito objetivo ${ }^{27}$.

Fora dessas hipóteses excepcionais, consideram-se tais interesses passíveis de proteção indireta. Essa forma de proteção pode se dar mediante uma relação de dependência com outro interesse que é juridicamente amparado, por decorrência do princípio da interdependência dos interesses. Fala-se, nessas hipóteses, em interesses mediatamente ou ocasionalmente protegidos $^{28}$, porquanto sua proteção só se efetivaria enquanto aquele interesse principal fosse tutelado. $\mathrm{O}$ direito de um sujeito de impedir seu vizinho de edificar pode proporcionar a proteção ao interesse dos demais vizinhos de gozarem de uma vista ampla da região que circunda seus imóveis. Caso aquele sujeito permita a realização da obra, contudo, em princípio os demais vizinhos nada poderiam fazer, restando prejudicados aqueles seus interesses ${ }^{29}$.

Outros interesses individuais são diretamente protegidos pelo ordenamento, mas esta proteção é sujeita ou condicionada ao atendimento de um interesse da coletividade. Desse modo, em caso de conflito com outro interesse individual, aqueles prevalecem; mas sucumbem quando conflitantes com o interesse da coletividade a que se subordinam. $\mathrm{O}$ sujeito a quem foi outorgada permissão para construir e explorar quiosques na via pública possui mero interesse condicionalmente protegido eis que o seu direito é condicionado ao atendimento do interesse público subjacente, mantendo a permissão apenas a título precário, podendo vir a ser limitada ou revogada para atendimento do interesse público, como, por exemplo, com o objetivo de favorecer o tráfego de veículos e pedestres.

O eventual prejuízo comercial que advirá aos que mantêm postos de gasolina no local, pela instalação de um outro a menos de mil metros, com eventual ofensa a postura municipal, mas sem afetar o prédio mesmo, não legitima aqueles à propositura da ação de nunciação de obra nova. Manutenção do acórdão que reconheceu nos autores apenas o propósito de inibir a livre concorrência comercial.

Recurso não conhecido." (STJ, REsp 264.806/MG, Rel. Ministro RUY ROSADO DE AGUIAR, QUARTA TURMA, julgado em 05/10/2000, DJ 18/12/2000, p. 207).

27 Para Oswaldo Bandeira de Mello seria o caso da ação popular (BANDEIRA DE MELLO, 1979, pp. 230/231).

${ }^{28}$ CARNELUTTI, 2006, p. 80.

29 Alguma proteção autônoma pode vir a ser prevista para os interesses ocasionalmente protegidos, atribuindo-se aos seus titulares certo grau de proteção em face do titular do interesse principal, de forma a vedar-se que este aja de forma irracional ou abusiva em detrimento dos demais (CARNELUTTI, 2006, p. $80)$. 
Os titulares de interesses imperfeitos podem fazer prevalecer o seu interesse perante terceiros, pois em face destes possuem verdadeiro direito subjetivo ${ }^{30}$. Contra o Estado, entretanto, as possibilidades de defesa são sensivelmente mais restritas, eis que seus interesses são diretamente subordinados ao interesse público.

Para designar os interesses ocasionalmente e condicionalmente protegidos, no mais das vezes emprega-se a expressão interesses legítimos ${ }^{31}$. A razão prática da distinção entre estes e os direitos subjetivos se mostra especialmente relevante em países em que há o contencioso administrativo, como na Itália, pois, modo geral, serve de parâmetro para separar a competência da justiça ordinária, foro apropriado para a tutela dos direitos subjetivos, da administrativa, a quem compete o exame dos casos envolvendo interesses legítimos. Os administrativistas italianos dedicaram-se a esmiuçar tal distinção, demonstrando não se tratar de tarefa das mais simples. Dentre os critérios identificados para separar os interesses legítimos dos direitos subjetivos, aponta-se (i) o critério do interesse, segundo o qual se considera o direito subjetivo tutelado como interesse imediato e o interesse legítimo apenas de forma mediata, como reflexo da tutela do interesse coletivo; (ii) o critério da categoria filosófica, que propugna ser o direito um meio para a satisfação de um fim que constitui o interesse, distinguindo-se um do outro, dessa forma, como meio e fim; (iii) o critério da competência da autoridade administrativa, indicando existir direito subjetivo com relação à competência administrativa vinculada e interesse legítimo com referência à competência legislativa discricionária; e (iv) o critério do poder jurídico de ação, de acordo com o qual se considera o direito subjetivo passível de tutela direta e o interesse legítimo passível de tutela reflexa, ocasional, por refração ou condicionada pelo interesse geral $^{32}$.

Dessa classificação, podem ser extraídos três grupos de interesses juridicamente protegidos. Em primeiro lugar, aqueles que correspondem a direitos subjetivos, garantindo ao seu titular proteção plena e incondicional. Em segundo lugar, os conhecidos como interesses legítimos e interesses simples, que recebem proteção limitada ou condicional, sujeitando-se a um interesse com que são coincidentes ou do qual são complementares, de natureza pública ou coletiva. Finalmente, em contraste com os anteriores de índole

\footnotetext{
${ }^{30}$ BANDEIRA DE MELLO, 1979, p. 230.

${ }^{31}$ Questiona-se a respeito do rigor técnico de tal uso, porquanto os direitos subjetivos perfeitos não deixam de ser legítimos. (NALINI, 1985, p. 245/246).

${ }^{32}$ NALINI, 1985, p. 246.
} 
individual, os interesses gerais, coletivos ou públicos, cuja implementação leva à proteção daqueles interesses do segundo grupo.

Em razão de sua posição central para o Direito Privado, inclusive com implicações no desenvolvimento do processo civil, passa-se ao exame do direito subjetivo.

\subsection{DIREITO SUBJETIVO}

Instituto com destacada importância histórica para os estudiosos do Direito ${ }^{33}$, o direito subjetivo foi objeto de inúmeras teorias tendo por escopo a sua identificação e conceituação $^{34}$, muitas das quais o contrapondo à noção de direito objetivo, elementos que são da clássica dicotomia direito objetivo - direito subjetivo. Diante da vasta quantidade dessas teorias e de suas muitas especificidades, a sua exposição e análise não se acomodariam no escopo do presente estudo. Entretanto, alguns aspectos das discussões envolvendo as de maior destaque merecem ser abordados para evidenciarem a relação entre as noções de direito subjetivo e interesse.

De costume, a explicitação do conceito de direito subjetivo parte da distinção de origem romana entre facultas agendi e norma agendi, sendo a primeira entendida como as faculdades de ação atribuídas ao sujeito por regras jurídicas objetivas, que constituem a segunda. Nesse tocante, tal distinção corresponderia, respectivamente, ao que se entende por direito subjetivo e direito objetivo ${ }^{35}$. O conjunto ordenado de normas jurídicas abstratas prescritoras de condutas compõem o direito objetivo. Na medida em que tais normas incidam sobre fatos concretos atribuindo a determinado sujeito uma faculdade de

\footnotetext{
33 "A sistemática jurídica do mundo ocidental, ainda hoje se baseia neste conceito nuclear, que é o conceito do Direito subjetivo. É conceito altamente polêmico e difícil de ser definido nas suas linhas fundamentais." (MOREIRA ALVES, José Carlos. Direito Subjetivo, Pretensão e Ação. Revista de Processo n. 47, ano 12, julho/setembro 1987, pp. 109).

34 Vicente Ráo, em aprofundado estudo a respeito das diversas teorias doutrinárias a respeito do direito subjetivo, as classifica em três grandes grupos: as teorias afirmativas, as teorias negativas e as teorias absolutistas (RÁO, 1999, p. 527 e seguintes).

${ }^{35}$ A esse respeito, Vicente Ráo identifica o conceito de direito subjetivo à faculdade de agir (facultas agendi) de acordo com o que a norma que disciplina a conduta dispõe (norma agendi), constituindo tal norma o direito objetivo. Como mandamento ou diretriz, o direito objetivo residiria fora do ente titular do direito subjetivo. (p. 191) A faculdade, que caracteriza o direito subjetivo e é interna ao sujeito, consistiria em um "poder de ação, cujo exercício depende da vontade do respectivo titular", enquanto a prescrição atributiva, demarcadora do direito objetivo e atribuidora de tal faculdade, seria uma "expressão da vontade geral". Ambos, preceito e faculdade, surgem simultaneamente à aquisição de força obrigatória pela norma, como duas expressões de um mesmo fenômeno, que é o direito. (RÁO, 1999, p. 192)
} 
ação, surge o direito subjetivo. Sem retirar o mérito dessa concepção de demonstrar a associação entre direito objetivo e direito subjetivo, constituindo ambos expressões diversas de um mesmo fenômeno ${ }^{36}$, hodiernamente tem-se que o direito subjetivo não caracteriza uma mera faculdade, podendo compreender diversas, que constituem, na realidade, o modo de exercício do direito ${ }^{37}$.

As discussões a respeito do conceito de direito subjetivo, apesar de iniciadas previamente, tomaram corpo no século XIX, com o embate entre as teorias da vontade e do interesse. A teoria da vontade, tendo por principais expoentes Friedrich Carl Von Savigny e Bernhard Windscheid, coloca a vontade no centro do conceito de direito subjetivo. Surge a teoria em um contexto histórico de intenso liberalismo, firmando-se o dogma da vontade, de caráter eminentemente individualista, de forma a enaltecer o poder agir segundo a vontade dado pela ordem jurídica ${ }^{38}$. As regras de direito objetivo, enquanto expressão da vontade geral ${ }^{39}$, delineiam os contornos das relações jurídicas estabelecidas entre as pessoas atribuindo no seu interior à vontade individual "um campo dentro de cujos limites ela possa atuar independentemente de qualquer vontade alheia" ${ }^{40}$. Para Bernhard Windscheid, direito subjetivo seria definido como poder ou domínio da vontade livre do homem juridicamente protegido $^{41}$. De acordo com Miguel Reale, nessa visão, a vontade juridicamente protegida é o direito subjetivo ${ }^{42}$.

Característica diferenciadora do homem em relação aos outros animais, cumpre proteger-se a vontade de forma a que venha a acarretar consequências no mundo jurídico, concretizando a liberdade humana. A vontade é a expressão do poder do ser humano de

\footnotetext{
${ }^{36}$ PEREIRA, Caio Mário da Silva. Instituições de Direito Civil. vol. I. Atualizado por Maria Celina Bodin de Moraes. 20. ed. Rio de Janeiro: Forense, 2004, p. 14.

${ }^{37}$ REALE, Miguel. Lições Preliminares de Direito. 24. ed., São Paulo: Saraiva, 1998, pp. 251/252.

${ }^{38}$ MOREIRA ALVES, 1987, pp. 110/111.

39 "Prevalece a vontade, no direito subjetivo, como consequência lógica do consentimento de toda sociedade, para que o sujeito ativo tenha o poder de exercê-la, nos limites ditados pela norma jurídica." (LISBOA, Roberto Senise. Contratos Difusos e Coletivos: consumidor, meio ambiente, trabalho, agrário, locação, autor. São Paulo: RT, 1997, p. 40).

${ }^{40}$ RÁO, 1999, p. 531. Entretanto, essa limitação imposta pelas regras de direto objetivo não está presente em todas as teorias da vontade, havendo quem entenda ser a vontade um fator de poder irrestrito a sujeitar as vontades alheias (PEREIRA, 2004, p. 34).

${ }^{41}$ AMARAL JUNIOR, Alberto do. Lições de Direito. Barueri: Manole, 2011, p. 39. FERRAZ JUNIOR, Tercio Sampaio. Introdução ao Estudo do Direito: Técnica, decisão, dominação. 2. ed. São Paulo: Atlas, 1994, p. 148.

${ }^{42}$ REALE, 1998, p. 253.
} 
optar, e isso constitui o pressuposto de sua responsabilidade ${ }^{43}$. Partindo da noção de interesse apresentada e das relações que entre si podem estabelecer os interesses, a vontade consubstancia a escolha dos interesses a serem perseguidos ou defendidos, especialmente nos casos em que se põem em conflito intrassubjetivo. A teoria da vontade elege esse espaço protegido de atuação da vontade humana como elemento essencial do direito subjetivo $^{44}$.

As críticas à teoria da vontade ressaltam a existência de direitos sem ou até mesmo contra a vontade de seu titular. Aqueles considerados incapazes, apesar de desprovidos de livre vontade, são também titulares de direitos ${ }^{45}$. Do mesmo modo, alguns direitos surgem ou persistem nada obstante o desconhecimento ou a renúncia expressa do seu titular, como no caso do direito a férias atribuído ao empregado, que se sustenta mesmo que seu beneficiário dele não tenha conhecimento ou dele tenha aberto mão ${ }^{46}$.

Contrapondo-se à teoria da vontade, Rudolf Von Jhering atribui diferente configuração ao conceito de direito subjetivo, criando aquela que veio a ser conhecida por teoria do interesse, pela qual se considera direito subjetivo o interesse juridicamente protegido. No quadro dos interesses em conflito intersubjetivo revelados pelo convívio humano, aqueles protegidos pelo direito seriam direitos subjetivos ${ }^{47}$. Dois são os seus elementos constituintes, sendo o primeiro, de caráter substancial, atinente à vantagem, proveito ou

\footnotetext{
43 "De início, a vontade livre é um dado existencial: pode ser constatado mas não pode ser demonstrado. Faz parte da essência humana este poder de optar. O homem age e a causa de sua ação é a sua vontade livre. Nisto o homem é diferente dos animais, regidos por instintos. A vontade livre é, assim, condição da responsabilidade. Só o homem é responsável, moral e juridicamente" (FERRAZ JUNIOR, 1994, pp. 148/149).

${ }^{44}$ Como um desdobramento da teoria da vontade, Giorgio Del Vecchio sustenta que o elemento central do direito subjetivo não é a vontade efetiva, mas sim a potencial. "ao direito não é essencial a vontade actual, mas a potencial - a possibilidade de querer atribuída e reconhecida ao sujeito" (DEL VECCHIO, Giorgio. Lições de Filosofia do Direito. Tradução de António José Brandão. 5. ed., Coimbra: Arménio Amado, 1979, p. 442).

${ }^{45}$ Segundo Tercio Sampaio Ferraz Junior: "Mas, assim, a teoria da vontade deixa de explicar que também loucos ou crianças tenham direito subjetivo. Afinal, mesmo sem corresponder ao tipo médio, o louco ou a criança tem direitos à herança, à propriedade. Ora, dizer que, nesses casos, a sua base ainda é a vontade livre é apelar para uma ficção que não cobre, corretamente, o âmbito do direito subjetivo." (FERRAZ JUNIOR, 1994, p. 149). Vicente Ráo entende que esse fato não desqualifica a teoria do interesse, porquanto o incapaz se faria representar por um indivíduo capaz. "E, ainda, preciso é ter-se em mente que o direito acompanha a natureza e as contingências da vida, pressupondo, portanto, a existência da lei natural de interdependência e de complementação existente entre os seres humanos; com este fundamento, por meio do instituto da representação, supre a falta ou deficiência da vontade dos incapazes, substituindo-a pela vontade de seus representantes, que agem em nome e em conta de seus representados." (FERRAZ JUNIOR, 1994, pp. 535/536).

${ }^{46}$ REALE, 1998, p. 254.

${ }^{47}$ FERRAZ JUNIOR, 1994, p. 149.
} 
utilidade proporcionada pela situação fática e assegurada pelo direito. Tal elemento nada mais seria do que o interesse propriamente dito e configuraria o fim do direito subjetivo, servindo o direito como o meio para o seu atendimento ${ }^{48}$. O segundo, de ordem formal, residiria na proteção jurisdicional do direito, ou os remédios jurídicos disponibilizados pelo Estado para a sua tutela. Sob essa acepção, mesmo aqueles sujeitos incapazes de formar ou exprimir sua vontade, como os loucos, seriam titulares de um direito subjetivo na medida em que o mesmo lhes seja capaz de proporcionar uma utilidade ou proveito e seja protegido pela norma. Provendo solução para as críticas à teoria da vontade, as ideias de Rudolf Von Jhering foram amplamente disseminadas e encontram muitos adeptos, como, no Brasil, Clóvis Bevilacqua, responsável pela elaboração do Código Civil de $1916^{49}$.

Não escapou de críticas, todavia, a teoria do interesse. Dentre as quais, menciona-se com mais frequência a vagueza e indeterminação do conceito de interesse; a existência de interesses juridicamente protegidos que não constituem direitos subjetivos ${ }^{50}$, como, por exemplo, os interesses protegidos pelas normas de trânsito ou os referentes à manutenção da beleza da paisagem; e a possibilidade do titular do direito subjetivo não possuir interesse na proteção desse seu direito, de forma a se conceber a possibilidade de um direito corresponder a um desinteresse do seu titular.

Tércio Sampaio Ferraz Junior conclui que a teoria é demasiado privatista, não explicando bem direitos de natureza pública, como o direito ao voto, o qual não encontraria correspondência em um interesse, vez que não constitui a função principal desse direito a de que o voto seja recebido e computado pelo Estado ${ }^{51}$. Da mesma forma, na esfera penal, a punição de um delito não corresponderia a interesse, eis que não traria vantagem a ninguém.

\footnotetext{
${ }^{48}$ Rudolf Von Jhering é adepto de orientação filosófica finalista, partindo da premissa de que o direito visa determinado fim, adota o método teleológico ou finalista para estudá-lo (MOREIRA ALVES, 1987, p. 111).

${ }^{49}$ RÁO, 1999, p. 541. Clóvis Beviláqua incorpora a noção de interesse mesmo no conceito de direito objetivo, considerando-o uma forma de regulamentação dos interesses humanos segundo a ideia de justiça dominante no momento, constituindo o ordenamento jurídico a "justa proporção dos interesses colidentes". (BEVILACQUA, Clóvis. Theoria Geral do Direito Civil. Campinas: RED, 1999, p. 10).

50 "Também contra a teoria de Jhering foram formuladas críticas procedentes. Em primeiro lugar, lembrou-se que a palavra interesse é de acepção tão ampla, tão genérica que nos deixa em plena indeterminação. Nada há mais vago do que aquilo que interessa. Em segundo lugar, nem tudo que interessa, embora juridicamente protegido, envolve o aparecimento do direito subjetivo." (REALE, 1998, p. 256).

${ }^{51}$ FERRAZ JUNIOR, 1994, pp. 149/150. Em que pesem essas considerações, há de se ponderar a respeito da possibilidade do direito ao voto corresponder a um interesse instrumental do cidadão de indiretamente participar do poder por intermédio da eleição de representantes. Sob a perspectiva do dever, o voto do cidadão seria objeto de um interesse geral, de forma a preservar a democracia.
} 
Vicente Ráo vai além, classificando a teoria do interesse como utilitária e egoísta. Apesar de reconhecer que Rudolf Von Jhering aceitava a existência de interesses associados a bens e valores de natureza moral como "a personalidade, a liberdade, a honra, os laços de família", aduz que os direitos a eles correspondentes são tomados pela perspectiva da vantagem ou benefício que proporcionam ao seu titular, sem considerar que muitos têm razão de ser em um desinteressado sentimento de altruísmo, sendo praticados com espírito de sacrifício, e não visando um proveito material ${ }^{52}$. Além disso, Vicente Ráo, fazendo referência aos críticos da teoria do interesse, acusa Rudolf Von Jhering de definir o direito subjetivo pelo seu fim e não pela sua essência ${ }^{53}$. Mesmo sob o viés finalístico, entretanto, por mais que concorde que o interesse possa representar o fim imediato de alguns direitos subjetivos, opõe-se a que seja considerado o seu fim último, eis que, na visão do autor, a finalidade do direito está relacionada ao "destino natural do homem". Prosseguindo em suas críticas, aduz que nem sempre a titularidade do direito e do interesse se confundem na mesma pessoa, como no caso da propriedade gravada de encargo, vez que o encargo constitui interesse de quem não é o titular da propriedade; que direitos podem ser protegidos por outra via que não a jurisdicional; e que há interesses protegidos juridicamente que não configuram direito subjetivo ${ }^{54}$.

Diante da contraposição entre as duas teorias que predominaram no século XIX e as críticas a elas formuladas, novas teorias espontaram conjugando os elementos da vontade e do interesse ${ }^{55}$, e que, foram, assim, consideradas teorias mistas ou ecléticas. Dentre elas, a de Thon $^{56}$, a que se denominou teoria da garantia ${ }^{57}$, para quem o direito subjetivo equivale

\footnotetext{
${ }^{52}$ RÁO, 1999, pp. 541/542. Não se considerou, contudo, da possibilidade das vantagens e benefícios de ordem moral, de forma a que mesmo a execução altruísta de um direito corresponda a um interesse por proporcionar ao seu titular a satisfação de sua necessidade moral de prover a outrem. Bentham, defensor do utilitarismo, conforme exposição de Alf Ross, admite que o ser humano não age apenas com base em sentimentos egoístas, concebendo ações altruístas e de auto-sacrifício, mas que também se destinam a satisfazer seu sentimento de simpatia pelos outros (ROSS, 2003, p. 337).

${ }^{53}$ Giorgio Del Vecchio aduz que qualquer direito subjetivo tem um conteúdo de utilidade, de forma que o interesse represente o objeto do direito. Tal objeto, contudo, não se confunde com o próprio direito. (Del Vecchio, 1979, p. 442).

${ }_{55}^{54}$ RÁO, 1999, pp. 541/543.

${ }^{55}$ José Carlos Moreira Alves vai além e inclui a tutela nos elementos adotados por essas teorias. Assim, indica que para autores mais modernos, o direito subjetivo consiste no "poder de vontade para a satisfação dos interesses em conformidade com a norma jurídica", o que seria por demais abrangente, englobando, dentre outros, direitos potestativos e interesses legítimos (MOREIRA ALVES, 1987, p. 112).

${ }^{56}$ Não é pacífica a qualificação da teoria de Thon como uma teoria eclética como o faz Vicente Ráo (1999, p. 545), havendo quem a classifique apenas como teoria da garantia (FERRAZ JUNIOR, 1994, p. 149).

${ }^{57}$ FERRAZ JUNIOR, 1994, p. 149.
} 
a um meio de proteção do interesse $\mathrm{e}^{58}$, ou seja, a garantia conferida pelo direito objetivo, desviando o foco do interesse para a sua proteção. A cerca que circunda e protege o jardim e não o jardim propriamente dito. Essa acepção, todavia, teria o desmérito de confundir o direito com sua proteção, dele extirpando uma identidade própria, tratando-o como uma decorrência de uma obrigação e não como "alguma faculdade subsistente em si" ${ }^{59}$. De acordo com a teoria de Jellinek, o direito subjetivo constituiria o poder de agir do titular de um interesse protegido para tutelá-lo ${ }^{60}$. O antagonismo entre a teoria da vontade e do interesse seria apenas aparente, eis que uma complementa a outra. $\mathrm{O}$ direito subjetivo conjugaria ambos os elementos, caracterizando "o interesse protegido enquanto atribui a alguém um poder de querer" 61 .

Ressalte-se, a esse respeito, a concepção eclética de Francesco Carnelutti, especialmente em razão da centralidade que ocupa o interesse para a sua obra. Denomina-se relação jurídica o conflito de interesses regulado pelo Direito ${ }^{62}$, no qual um é prevalecente e o outro subordinado. A relação jurídica tem por elementos duas situações: a situação jurídica passiva, que consiste na subordinação de um interesse; e a situação jurídica ativa, que consubstancia o prevalecimento de um interesse, operando-se ambos - subordinação e prevalecimento - por meio de uma medida jurídica, ou seja, um meio adotado para a imposição do preceito $^{63}$.

Tratando-se tal medida jurídica de uma sanção, para o titular do interesse subordinado a relação jurídica representa uma obrigação, e para o titular do interesse prevalecente, um direito subjetivo, entendido como "um poder atribuído à vontade de uma pessoa para o prevalecimento do seu interesse" ${ }^{64}$.

Segundo Francesco Carnelutti, interesse protegido e direito subjetivo não são sinônimos, sendo o primeiro um gênero do qual o segundo é espécie. $\mathrm{O}$ interesse protegido configura direito subjetivo na medida em que as sanções cominadas dependam da vontade do

\footnotetext{
${ }^{58}$ RÁO, 1999, pp 545/546.

${ }^{59}$ FERRAZ JUNIOR, 1994, p. 149.

${ }^{60}$ AMARAL JUNIOR, 2011, p. 41.

${ }^{61}$ REALE, 1998, p. 257.

${ }^{62}$ CARNELUTTI, 2000, pp. 75/76.

${ }^{63}$ CARNELUTTI, 2000, p. 76.

${ }^{64}$ CARNELUTTI, 2000, p.77.
} 
interessado ${ }^{65}$. Dessa forma, o direito subjetivo confere ao seu titular o poder de fazer atuar o Direto objetivo, eis que só haverá a tutela se houver a vontade do interessado ${ }^{66}$.

A relação jurídica é estabelecida entre o sujeito da obrigação e o sujeito do interesse protegido. Geralmente o sujeito do interesse e o sujeito da vontade se confundem em um só, especialmente se tratar-se de pessoa natural. Casos há, entretanto, em que o sujeito que manifesta a vontade se distingue do sujeito do interesse, como na hipótese da incapacidade jurídica do último ou se o interesse em questão for de natureza coletiva. Sendo desta natureza, não seria conveniente exigir que todos os membros do grupo de interessados manifestassem sua vontade, optando-se, de modo, a se atribuir a um de tais membros ou a um terceiro tal função, assumindo a condição de representante. Está Francesco Carnelutti aqui a se referir a grupos organizados ou institucionalizados, como uma sociedade, em que a vontade coletiva é manifestada pelos seus administradores. O sujeito dos interesses coletivos seria, assim, a organização (universitas) de homens ${ }^{67}$.

O mérito das teorias mistas, de acordo com Caio Mário da Silva Pereira, reside na associação do elemento subjetivo psicológico (vontade), com o objetivo teleológico (interesse), de forma a constituir o direito subjetivo a "faculdade de querer, porém dirigida a determinado fim" caracterizado pelo interesse de agir ${ }^{68}$, perseguido dentro dos preceitos estatuídos pela ordem jurídica. A vontade por si só, não se sustenta a não ser que seja voltada a alguma finalidade, em conformidade com a ordem jurídica. Assim, para o autor o direito subjetivo seria composto por "poder de ação, interesse e submissão ao direito objetivo" $^{69}$.

Padeceram tais teorias, entretanto, de problemas semelhantes às suas antecessoras, porquanto apesar das soluções ecléticas buscarem congregar as características positivas das teorias em que se inspiram, acabam por também reunir as suas dificuldades ${ }^{70}$. Giorgio Del

\footnotetext{
${ }^{65}$ Nessa concepção, não só os interesses individuais, como também os coletivos e os públicos podem representar direito subjetivo. Para tanto, exige-se apenas que ao titular ou titulares se atribua o poder de fazer prevalecer o interesse. No caso do interesse público, caracterizar-se-ia direito subjetivo público. (CARNELUTTI, 2006, p. 80).

${ }^{66}$ Carnelutti, Sistema, vol. 1, p. 79.

${ }^{67}$ CARNELUTTI, 2006, p. 84. Além dos sujeitos, uma relação jurídica tem que ter um objeto. O objeto jurídico de uma relação jurídica é necessariamente um bem jurídico, material ou imaterial, que tenha a aptidão de satisfazer uma necessidade, sendo economicamente limitado. CARNELUTTI, 2006, p. 85.

${ }^{68}$ Expressão aqui utilizada não no sentido de interesse processual, mas sim interesse de tomar uma atitude.

${ }^{69}$ PEREIRA, 2004, pp. 35/36.

${ }^{70}$ REALE, 1998, 257.
} 
Vecchio aponta que o próprio Rudolf Von Jhering veio a alterar seu entendimento, incorporando ao conceito o reconhecimento da vontade individual ao conceber o direito subjetivo como a "auto-proteção do interesse", de forma a atribuir ao próprio interessado a iniciativa de proteger o seu interesse. A mudança operada acabou por tornar Rudolf Von Jhering indiretamente alvo das críticas por ele mesmo formuladas contra a teoria da vontade, eis que ao incapaz não seria possível proteger seu interesse ${ }^{71}$.

$\mathrm{Na}$ contramão das teorias que gravitam em torno da vontade e do interesse, as teorias negativas, como se infere de sua denominação, de alguma forma negam a existência do direito subjetivo como instituto jurídico autônomo. Duguit defende a existência única do direito objetivo, repudiando a noção de direito subjetivo porquanto ao indivíduo não seria dado o poder de comandar e dominar a vontade do indivíduo subordinado por ter sua vontade uma qualidade superior. A regra jurídica caracterizadora do direito objetivo, sob a perspectiva do indivíduo configuraria uma situação jurídica, mas sem lhe atribuir qualquer $\operatorname{poder}^{72}$. Kelsen, autor da Teoria Pura do Direito, entende ser o Direito um "sistema lógicogradativo de normas" ${ }^{73}$ encerrado no mundo do dever ser, em contraposição ao mudo do ser. A norma jurídica seria a expressão do Direito trazendo em si um conteúdo prescritivo de ordem formal e objetiva. Fala-se em direito subjetivo ao se considerar essa mesma norma, mas enquanto atribui ao sujeito o poder jurídico correspondente ao dever nela expresso. Considerado como mera subjetivação do direito objetivo, restringe-se o direito subjetivo "à mera atribuição de um dever ao destinatário da norma" ${ }^{74}$, esvaziando-o de conteúdo. Elimina-se, assim, a referência aos interesses e à vontade dos sujeitos como elementos relevantes ao direito, diante de sua objetividade ínsita ${ }^{75}$.

\footnotetext{
71 Para Giorgio Del Vecchio, todavia, essa crítica não é pertinente, eis que o incapaz tem sua vontade manifestada pelo seu representante.

${ }^{72}$ PEREIRA, 2004, pp. 32/33.

${ }^{73}$ REALE, 1998, p. 258.

${ }^{74}$ REALE, 1998, p. 259.

75 "A Teoria Pura do Direito afasta este dualismo ao analisar o conceito de pessoa como a personificação de um complexo de normas jurídicas, ao reduzir o dever e o direito subjetivo (em sentido técnico) à norma jurídica que liga uma sanção a determinada conduta de um indivíduo e ao tornar a execução de sanção dependente de uma ação judicial a tal fim dirigida; quer dizer: reconduzindo o chamado direito em sentido subjetivo ao Direito objetivo. Desta forma, supera-se aquela posição subjetivista em face do Direito a cujo serviço se encontra o conceito de direito em sentido subjetivo: aquela concepção forense ou advocacial que apenas considera o Direito do ponto de vista dos interesses das partes, isto é, aquela concepção que o visualiza tendo apenas em mira saber o que ele significa para o indivíduo, em que medida lhe aproveita, quer dizer, em que medida serve o seu interesse, ou o prejudica, isto é, o ameaça com um mal." (KELSEN, Hans. Teoria Pura do Direito. Tradução de João Baptista Machado. São Paulo: Martins Fontes, 1995, p. 213).
} 
Críticas também foram endereçadas às teorias negativistas. Afirma-se ser logicamente inexata a distinção entre os mundos do dever ser e do ser de modo a confinar o direito ao primeiro. Isso porque o direito tem origem graças às necessidades práticas experimentadas no mundo do ser, e incide sobre condutas individuais também praticadas nesse mesmo mundo. Também da atividade humana, compreendida como manifestação da vontade, é que com frequência surge a proposição do direito. Assim, apesar da separação teórica das duas ordens ser possível, não é razoável extirpar o ordenamento jurídico da realidade concreta $^{76}$.

Caio Mário da Silva Pereira lembra que admitir a existência do direito subjetivo não é "expressão de extremado individualismo", sendo certo que, mesmo em se reconhecendo a preponderância do direito social, não há de se negar o papel do direito subjetivo de explicar a atividade do indivíduo frente ao direito objetivo, com as limitações que o impedem de ser exercido de forma absoluta ou com o sacrifício dos outros indivíduos ${ }^{77}$.

Outras acepções a respeito do direito subjetivo afloram entre os estudiosos do direito, notando-se a tendência de, a despeito das variações apresentadas, nele caracterizarem o poder de exigir algo de alguém em conformidade com o que dispõem o ordenamento.

Vicente Ráo, por exemplo, revela-se simpático à teoria da vontade, criticando-a apenas por faltar-lhe a indicação da finalidade do direito subjetivo como um de seus elementos constituintes $^{78}$. A vontade teria relevância para o direito subjetivo na medida em que o exercício da faculdade traduziria um ato de vontade que, mediante a obtenção de bens de valor individual ou social necessários ou úteis, voltar-se-ia aos fins do direito subjetivo ${ }^{79}$, os quais consistiriam no desenvolvimento das aptidões espirituais, intelectuais e materiais do seu titular, conforme "os fins ditados por sua própria natureza" ${ }^{80}$. Com essas considerações conceitua direito subjetivo como:

\footnotetext{
${ }^{76}$ RÁO, 1999, 564.

${ }^{77}$ PEREIRA, 2004, p. 33.

${ }^{78}$ RÁO, 1999, p. 537.

79 "A própria norma jurídica atributiva que enuncia, rege e protege o direito, com este direito, só por só, não se confunde; isolada, que fosse, do titular, da manifestação da vontade, da ação ou relação e do objeto, ela não passaria de mero conceito lógico.

E o fim último e supremo do direito subjetivo, que é o livre desenvolvimento e aperfeiçoamento das pessoas físicas ou jurídicas, dentro da ordem social, só assume valor quando contemplado como causa final do direito, isto é, do direito que resulta da conjunção de todos os elementos que acabamos de mencionar [caracterizadores do direito subjetivo]." (RÁO, 1999, p. 529).

${ }^{80}$ RÁO, 1999, p. 528.
} 
o poder de ação determinado pela vontade que, manifestando-se através das relações entre as pessoas, recai sobre atos ou bens materiais ou imateriais e é disciplinado e protegido pela ordem jurídica, a fim de assegurar a todos e a cada qual o livre exercício de suas aptidões naturais, em benefício próprio, ou de outrem, ou da comunhão social ${ }^{81}$.

Baseando-se na definição de Silvio Perozze, José Carlos Moreira Alves conceitua o direito subjetivo como um "poder, atribuído pela norma jurídica, e tutelado pela ordem jurídica, de exigir de outrem um determinado comportamento" ${ }^{82}$. A sua característica fundamental diferenciadora é a de ser um poder que corresponde a um dever, necessitando da colaboração de outrem, e, que, portanto, é violável. Por isso é que só há direito subjetivo se o Estado tutelar o titular do poder contra a violação ${ }^{83}$.

Partindo da definição de situação jurídica subjetiva como "a possibilidade de ser, pretender ou fazer algo, de maneira garantida, nos limites atributivos das regras de direito", Miguel Reale caracteriza o direito subjetivo como uma das formas de expressão de uma situação jurídica subjetiva, da mesma forma que o interesse legítimo constituiria outra. Nesse tocante, o direito subjetivo é a situação jurídica subjetiva em que há a possibilidade de uma pretensão associada à exigibilidade de uma prestação ou ato de outrem. $\mathrm{O}$ núcleo do conceito é a pretensão, com a relação de correspondência ou proporcionalidade entre aquilo que é pretendido por um e o que é devido pelo outro, estabelecendo a conexão entre o modelo normativo e a experiência concreta. Assim é que, para Miguel Reale, "direito subjetivo é a possibilidade de exigir-se, de maneira garantida, aquilo a que as normas de direito atribuem a alguém como próprio" ${ }^{84}$.

\footnotetext{
${ }^{81}$ RÁO, 1999, p. 615.

${ }^{82}$ MOREIRA ALVES, 1987, p. 113.

${ }^{83}$ Por mais que haja quem entenda que as obrigações naturais, tais como a dívida de jogo, e os direitos prescritos são direitos subjetivos, ainda que enfraquecidos, José Carlos Moreira Alves entende se tratarem de coisa diversa. Não são poder, pois não se pode exigir nada do devedor. Desse modo, assumem a feição de meras "causas jurídicas de retenção", que permitem ao seu titular reter eventual pagamento que lhe tenha sido efetuado.

${ }^{84}$ REALE, 1998, pp. 261/262.
} 
Segundo Alf Ross, em posição compartilhada por Tercio Sampaio Ferraz Junior ${ }^{85}$, a expressão direito subjetivo é despida de conteúdo semântico, não possuindo um significado próprio, mas servindo como uma técnica de linguagem para designar de forma condensada a ocorrência de uma série de fatos condicionantes e as suas consequências condicionadas, conforme previstas na norma jurídica. Dizer que um sujeito é proprietário de um bem significa afirmar, de forma sucinta, a ocorrência de certos fatos previstos na norma jurídica, que, por consequência, tornaram-no titular de um conjunto de "faculdades, liberdades, potestades e imunidades" também especificadas na norma ${ }^{86}$. Assim, não é a propriedade, em si, um nexo de causalidade entre os fatos condicionantes e as consequências condicionadas, servindo apenas para descrever o direito vigente ou a sua aplicação a situações concretas ${ }^{87}$. Nesse sentido, poderia a referência ao direito subjetivo ser excluída de uma frase sem lhe alterar o significado, bastando ser incluída a referência aos fatos condicionantes e às consequências condicionadas pertinentes.

Alf Ross identificando as situações típicas em que o conceito de direito subjetivo é empregado, sem qualquer pretensão a firmar critérios definidos, afirma ser, nesses casos, o conceito "usado unicamente para indicar uma situação na qual o ordenamento jurídico deseja assegurar a uma pessoa liberdade de poder se comportar - no âmbito de uma esfera específica - como lhe agrade, a fim de proteger seus próprios interesses" ${ }^{88}$. Consiste o direito subjetivo em aludido uso a "auto-afirmação autônoma do indivíduo", sem que por conta disso represente um excessivo individualismo, eis que mesmo com importantes condicionantes de cunho social, considera-se recomendável conceder a possibilidade de liberdade de ação ao indivíduo. Excluem-se do conceito de direito subjetivo as liberdades e poderes para a proteção de interesses sociais, aqui considerados como interesses de outros ou interesses comuns, pois nesses casos tais liberdades e poderes não são concedidos aos sujeitos para a defesa de seus interesses próprios, mas como uma função social, de forma a serem juridicamente limitados e sujeitados a controles, tais como as decorrentes das regras

\footnotetext{
${ }^{85}$ FERRAZ JUNIOR, 1994, pp. 150/155.

${ }^{86}$ ROSS, 2003, pp. 201 e seguintes.

87 "Podemos concluir, portanto, que em todos os contextos que consideramos, os enunciados referentes a direitos subjetivos cumprem a função de descrever o direto vigente ou sua aplicação a situações específicas concretas. Ao mesmo tempo, contudo, é preciso afirmar que o conceito de direito subjetivo não tem qualquer referência semântica;não designa fenômeno algum de nenhum tipo que esteja inserido entre os fatos condicionantes e as consequências condicionadas; é unicamente um meio que torna possível - de maneira mais ou menos precisa - representar o conteúdo de um conjunto de normas jurídicas, a saber, aquelas que ligam certa pluralidade disjuntiva de fatos condicionantes a certa pluralidade cumulativa de consequências jurídicas." (ROSS, 2003, p. 208).

${ }^{88}$ ROSS, 2003, p. 211.
} 
definidoras do abuso de poder, sendo tais liberdades e poderes melhor caracterizados como autoridade ou poder, ao invés de direito subjetivo.

O conteúdo do direito subjetivo inclui três elementos: faculdade dada ao titular em face de outros sujeitos; o poder para fazer valer essa faculdade e o poder de alienar o direito. Desses, o primeiro constitui o conteúdo específico de cada direito subjetivo, sendo os demais elementos subordinados presentes na generalidade dos direitos ${ }^{89}$. Nas situações típicas, referidos elementos correspondem a funções que se concentram em um mesmo sujeito. Assim, o titular do direito de propriedade pode gozar do bem, fazer prevalecer judicialmente suas faculdades decorrentes do direito de propriedade em face de terceiros, e pode aliená-lo. Entretanto, em situações atípicas é possível que sejam diversos o sujeito do interesse, o sujeito do processo e o sujeito da alienação, sem prejuízo da caracterização do direito subjetivo como tal. Considerando o mesmo direito de propriedade pertencente a um menor de idade, apesar de ser ele o sujeito do interesse, é o seu tutor legal o sujeito encarregado da administração do direito, de forma que a este cumpra uma autoridade (não direito) exercida no interesse do menor, sujeita a controle. Admite-se, assim, que o titular do interesse não seja o mesmo sujeito a quem seja conferido o poder de defender o direito em juízo. Diante dessa possibilidade, Alf Ross aduz a existência de direitos nos quais o sujeito do interesse seja um ente não humano, como, por exemplo, um indivíduo de outra espécie animal, sem que fique descaracterizado como direito subjetivo ${ }^{90}$. As dificuldades enfrentadas pelas teorias precedentes que buscavam identificar a essência do direito subjetivo, seja como vontade, interesse ou alguma conjugação de ambos, decorrem da existência dessas situações atípicas, nas quais todas as funções do direito não se concentram no mesmo indivíduo ${ }^{91}$.

\footnotetext{
${ }^{89}$ Podem direitos subjetivos existir mesmo sem todos esses elementos. Consumada a prescrição da pretensão, a defesa judicial do direito resta prejudicada. Certos direitos, como os de cunho personalíssimo, são tidos por inalienáveis (e.g., artigo 11 do Código Civil).

90 "É indubitável, está claro, que somente os seres humanos podem atuar como sujeitos de processos ou de disposição. Por outro lado, nada obriga a que os interesses reconhecidos pelas normas jurídicas como protegidos por um direito subjetivo sejam exclusivamente interesses humanos." (ROSS, 2003, p. 217). Para ilustrar, cita a possibilidade de legados serem deixados a animais.

91 "Por trás das diversas ideias de uma essência substancial ocultam-se diferentes pontos na situação típica de direito subjetivo: a vantagem fatual determinada pela restrição da liberdade alheia, o poder de instaurar processos e a competência (potestade) da alienação. As dificuldades com as quais cada uma das teorias tem que pelejar nascem do fato de que as funções, que estão integradas nas situações típicas, surgem fragmentadas entre sujeitos diferentes nas situações atípicas." (ROSS, 2003, p. 223).
} 
Diante de todos os esforços empregados para definir direito subjetivo, conclui-se que não apresenta limites conceituais bem definidos, imprecisão esta que não lhe retira utilidade. Conforme explana Tércio Sampaio Ferraz Júnior, com arrimo nos ensinamentos de Alf Ross, direito subjetivo é um lugar-comum, um topoi, servindo como "instrumento teórico que permite apresentar situações reguladas por normas de uma forma operacional" 92 . Segundo aludido autor:

Pelo exposto, percebe-se que a expressão direito subjetivo, em síntese, considerada à luz de sua função jurídica, aponta para a posição de um sujeito numa situação comunicativa, que se vê dotado de faculdades jurídicas (modo de interagir) que o titular pode fazer valer mediante procedimentos garantidos por normas. É possível, pois, ainda que sem rigor lógico absoluto, identificar no uso do conceito alguns elementos básicos que constituem, por assim dizes, sua estrutura. Em primeiro lugar aparece o sujeito de direito. Pode tratar-se de uma pessoa, de um grupo de pessoas ou apenas de uma entidade caracterizada por um conjunto de bens. O sujeito é o titular do direito. Em segundo lugar podemos falar do conteúdo do direito. Generalizando, trata-se da faculdade específica de constranger o outro, no caso de direitos pessoais, ou de dispor (gozar e usar a coisa) sem turbação de terceiros, no caso de direitos reais. Distinguem-se, em terceiro lugar, o objeto do direito. Em princípio tratase do bem protegido. No caso dos direitos reais, é a res, que necessariamente não é uma coisa física, como no direito do autor à obra. No caso dos direitos pessoais a noção de objeto se aplica com dificuldade, salvo se pensarmos aqui na noção de interesse protegido. Por fim, mencione-se a proteção do direito, isto é, a possibilidade de fazer valer o direito por meio da ação processual correspondente $e^{93}$.

Apesar das inconsistências que rondam o conceito de direito subjetivo, verifica-se que o seu emprego geralmente traz uma carga de significado comum. Nesse sentido, refere-se sempre a um sujeito, representando a subjetivação do direito objetivo. Representa o espaço de exercício de sua liberdade individual, com o poder ou faculdade de submeter terceiros à

\footnotetext{
${ }^{92}$ FERRAZ JUNIOR, 1994, p. 151.

${ }^{93}$ FERRAZ JUNIOR, 1994, pp. 154/155.
} 
sua vontade dentro dos contornos previstos pelo direito objetivo, de forma a privilegiar um interesse de que seja titular. Por decorrência, implica o poder de pleitear a tutela estatal do seu direito, ficando vedada a autotutela. Nota-se, assim, tratar-se tradicionalmente do instituto ícone do individualismo. Retrata a proteção jurídica de um interesse de características individuais, submetida à vontade de seu titular.

Ressalte-se, todavia, que o exercício do direito subjetivo veio a sofrer condicionantes com base na teoria do abuso e da função social dos direitos, derivada do reconhecimento do contexto e da relevância social dos mesmos e dos objetos a que se referem. Nesse tocante, hoje se considera ilícito o ato de "um titular de um direito que, ao exercê-lo, excede manifestamente os limites impostos pelo seu fim econômico ou social, pela boa-fé ou pelos bons costumes" (artigo 187 do Código Civil). Da mesma forma, apesar de se reconhecer o direito de propriedade como direito fundamental (artigo $5^{\circ}$, inciso XXII, da Constituição da República), impõe-se que deverá tal direito ser exercido de modo a que a propriedade atenda a sua função social (artigo $5^{\circ}$, inciso XXIII, da Constituição da República) ${ }^{94}$. Fica assim, retratado que, apesar do reconhecimento da esfera individual dos direitos, seu exercício sofre condicionantes sociais.

\footnotetext{
94 "O princípio vai além do ensinamento da Igreja, segundo o qual 'sobre toda propriedade particular pesa uma hipoteca social', mas tendente a uma simples vinculação obrigacional. Ele transforma a propriedade capitalista, sem socializá-la. Condiciona-a como um todo, não apenas seu exercício, possibilitando ao legislador entender com os modos de aquisição em geral ou com certos tipos de propriedade, com seu uso, gozo e disposição. Constitui, como já se disse, o fundamento do regime jurídico da propriedade, não de limitações, obrigações e ônus que podem apoiar-se - e sempre se apoiaram - em outros títulos de intervenção, como a ordem pública ou a atividade de polícia. A função social, assinala Pedro Escribano Collado, 'introduziu, na esfera interna do direito de propriedade, um interesse que pode não coincidir com o do proprietário e que, em todo caso, é estranho ao mesmo', constitui um princípio ordenador da propriedade privada e fundamento da atribuição desse direito, de seu reconhecimento e da sua garantia mesma, incidindo sobre seu próprio conteúdo." (SILVA, 1999, pp. 285/286).
} 


\section{CAPÍTULO 3. INTERESSES INDIVIDUAIS E METAINDIVIDUAIS}

\subsection{INTERESSES INDIVIDUAIS E METAINDIVIDUAIS}

A classificação dos interesses jurídicos apresentada se constrói sob uma ótica individualista, no sentido de representar em que medida pode um sujeito apoiar-se no ordenamento jurídico para fazer prevalecer o seu interesse em caso de conflito. Assim é que os direitos subjetivos são tradicionalmente tidos como a categoria de interesses à qual seu titular, ou quem o representa, possui a faculdade mais ampla de pleitear e obter a tutela do Estado. A proteção ensejada pelo direito subjetivo normalmente recai sobre o interesse do próprio titular.

Os interesses legítimos e o interesse simples, contudo, apresentam esfera de tutela individual mais reduzida, ficando dependentes do prevalecimento de outros interesses fora do controle daqueles a quem se atribui sua titularidade. Nesses casos, não se considera o mais relevante o interesse na esfera individual, mas sim o outro, que transcende a barreira do indivíduo, chamando-se-lhe de interesse transindividual ou coletivo ${ }^{1}$.

A caracterização do que constitui o interesse coletivo, sob a perspectiva subjetiva, parte do termo na sua acepção individual e nas relações que estabelece. Os interesses experimentados pelo homem não ficam sempre restritos a um indivíduo isolado. Conforme abordado alhures, por vezes estabelecem-se relações de solidariedade entre interesses de sujeitos distintos, podendo o de um servir como instrumento para a consecução do de outro. Se os interesses forem coincidentes e o seu objeto não for de tal forma escasso que o

\footnotetext{
${ }^{1}$ Não se adota aqui o termo técnico interesse coletivo que será abordado adiante, mas sim coletivo em contraposição ao individual. Apesar de não possuírem significado idêntico, no presente estudo, os termos interesses transindividuais, metaindividuais, plurindividuais e supraindividuais são empregados indistintamente, fazendo-se as indicações das características especiais a que se quer aludir na medida em que for necessário. Antonio Gidi alude às diversas denominações dadas ao termo (GIDI, Antonio. Coisa Julgada e Litispendência em Ações Coletivas. São Paulo: Saraiva, 1995, p. 26). Todavia, não se olvida que para Hugo Nigro Mazzilli, muito embora a jurisprudência e doutrina utilizem indistintamente os termos transindividuais e metaindividuais para designar interesses de grupos ou coletivos em sentido lado, à luz do rigor gramatical, é o primeiro termo um neologismo preferível, porquanto composto de prefixo e radical latinos, ao passo que o segundo é formado por prefixo grego e radical latino. (MAZZILLI, Hugo Nigro. A Defesa dos Interesses Difusos em Juízo: meio ambiente, consumidor, patrimônio cultural, patrimônio público e outros interesses. 20. ed.rev. ampl. e atual. São Paulo: Saraiva, 2007, p. 50).
} 
atendimento de um não prejudique o do outro, pode se estabelecer uma relação de colaboração entre os sujeitos para a satisfação conjunta dos seus interesses.

Essa colaboração pode se dar tanto visando o benefício próprio de cada um, por meio do aproveitamento das vantagens proporcionadas pelo esforço conjunto, como por razões altruístas, com base em um sentimento de unicidade em torno de um todo, neste caso perseguindo-se a satisfação conjunta dos interesses como se fosse o interesse de cada parte. Tem-se, aí, o interesse coletivo.

Nessa linha é o entendimento de Alf Ross. O autor constrói seu pensamento a partir do reconhecimento da existência de interesses individuais coincidentes, ou seja, que sejam semelhantes, mas experimentados por diferentes sujeitos. Além de coincidentes, referidos interesses podem também ser ligados, se o sucesso de um depender do sucesso do outro, de forma a demandarem a cooperação entre os sujeitos para que sejam satisfeitos. Essa ligação deriva de circunstâncias externas, objetivas, como uma situação de solidariedade que leve as partes a se aproximarem com vistas a satisfazerem seus interesses egoístas.

De outro modo, os interesses coincidentes podem ser comuns se os sujeitos identificarem, por razões altruístas, o conjunto que formam como uma única unidade coincidente com seu interesse próprio, de forma que busquem a satisfação de ambos os interesses individuais conjuntamente. Essa caracterização de interesses comuns decorre não de um elemento objetivo, mas sim subjetivo: a consciência de grupo, a identificação de cada parte com o todo, de forma a levá-la a agir não no seu próprio interesse, mas como um órgão desse todo que forma uma comunidade.

É nesse caso que se fala de um interesse coletivo, o qual, todavia, não constitui um interesse único experimentado por um sujeito comum supra-individual, e sim "uma constelação de interesses individuais experimentados sob pressupostos emocionais dados". A designação interesse coletivo caracteriza, assim, uma metáfora para a "experiência individual de coparticipação de interesses" ${ }^{2}$.

\footnotetext{
${ }^{2}$ ROSS, 2003, pp. 411/412.
} 
Com esse sentido metafórico de interesse coletivo, Alf Ross afirma que todo interesse é necessariamente individual, eis que os indivíduos são os únicos centros de experiência de que se tem conhecimento. Nega, assim, a comunidade ou sociedade como uma entidade detentora de necessidades próprias. As necessidades humanas são experimentadas individualmente, de forma que aquilo a que se refere como bem-estar da comunidade nada mais é do que o bem estar de seus membros considerados de forma agregada.

Ao se afirmar, por exemplo, a existência de um interesse social relacionado à habitação, quer-se normalmente referir a uma política habitacional que melhor satisfaça essa suposta necessidade comum. Ocorre que a demanda por habitações é individual de cada membro da comunidade. E por melhor que seja a política habitacional, "Se as circunstâncias não permitem a satisfação de todos os desejos, esses interesses [individuais dos membros da comunidade] passam a ser competitivos". Com tais considerações, conclui que "O interesse da comunidade (o bem-estar social) é a falácia que contorna essa desarmonia e fabrica um interesse único harmônico e um correspondente benefício único." 3 .

Francesco Carnelutti, de outro modo, concebe a noção de interesse coletivo a partir da perspectiva do seu objeto, assumindo características próprias que o distinguem do individual. Nada obstante, considera, assim como Alf Ross, que somente o homem individualmente considerado é capaz de experimentar necessidades, inexistindo necessidades da coletividade. A expressão necessidades coletivas traduziria apenas a somatória de necessidades individuais de todos os membros de uma dada coletividade ${ }^{4}$.

Assim, interesses coletivos constituiriam uma categoria própria que não se confundiria com interesses individuais ou a mera agregação destes. Definir-se-iam como uma posição favorável à satisfação da necessidade de um indivíduo que inevitavelmente também importaria o atendimento de necessidades iguais de outros, sendo indiferente o tamanho do grupo dos sujeitos atendidos, não obstante seja tão pequeno quanto uma família ou tão grande como um Estado. Nas palavras do autor:

\footnotetext{
${ }^{3}$ ROSS, 2003, p. 342.

${ }^{4}$ Retomando o pensamento de Carnelutti, há interesses que representam condição para satisfação de outros. Essa mesma lógica aplica-se com os interesses coletivos, admitindo-se a existência de um interesse que represente uma necessidade para a satisfação de um interesse coletivo. Enquanto a construção de uma estrada representa um interesse coletivo, também caracteriza uma necessidade para, por exemplo, a aquisição de material de construção e a realização de desapropriações. Há razões, assim, para se qualificar tal necessidade, voltada à satisfação de um interesse coletivo, como coletiva.
} 
"Portanto, há interesses individuais, quando a situação favorável para a satisfação de uma necessidade possa ser determinada com respeito a um indivíduo apenas. Pelo contrário, existem interesses coletivos, quando a situação favorável à satisfação de uma necessidade não possa ser determinada a não ser com respeito a vários indivíduos de uma vez, ou em outras palavras: quando a situação favorável a cada um, para a satisfação de uma necessidade sua, não pode ser determinada a não ser junto a outras idênticas situações favoráveis aos demais membros de um determinado grupo" 5 .

Cita, como exemplo, a abertura de uma estrada, utilizada por uma coletividade como via de tráfego entre duas localidades. Ou a estrada existe e satisfaz a necessidade de todos, ou ela não existe e ninguém tem sua necessidade de locomoção atendida. Assim, apesar das necessidades serem individuais, o aproveitamento do objeto é coletivo. Os interesses são coletivos em virtude das características do bem sobre os quais recaem.

Na classificação dos bens econômicos, caracterizam-se esses como coletivos, em oposição aos exclusivos. Os primeiros são justamente os bens que podem atender à necessidade de um grupo de pessoas concomitantemente, enquanto os últimos se prestam a satisfazerem apenas à necessidade de um indivíduo por vez, submetendo-se ao princípio da exclusão segundo o qual a apropriação do bem por um ser inexoravelmente acarreta a exclusão do seu uso por outro. Para ilustrar a diferença, tem-se como bem exclusivo um prato de comida, que ao saciar a fome de um indivíduo exaure a possibilidade de satisfazer a de qualquer outra pessoa. De outro modo, a segurança nacional pode ser vista como bem coletivo, pois ou ela é assegurada com relação a todos os cidadãos de um país, ou a nenhum deles ${ }^{6}$.

O fato de um bem ser coletivo não o impede de também apresentar características de exclusividade. Um clube é um bem coletivo para os seus associados, mas exclusivo com relação aos demais. Mesmo aqueles a quem é dado usufruir de um bem coletivo podem ter a possibilidade de usá-lo em diferentes graus. Seguindo com o mesmo exemplo, dentre os associados do clube, há aqueles que possuem o direito de usar um armário no vestiário, ficando os restantes privados de tal uso tendo em vista o número limitado de armários

\footnotetext{
${ }^{5}$ CARNELUTTI, 2000, p. 57.

${ }^{6}$ NUSDEO, 1997, pp. 43/46.
} 
instalados. Por isso é que a definição de um bem como predominantemente coletivo ou exclusivo depende do referencial e das circunstâncias em que ele se coloca. $\mathrm{O}$ ar, apesar de em condições normais ser considerado bem coletivo, deixa de ter tal característica para mergulhadores submersos no oceano.

Há bens que em razão de sua mera existência ou ampla disponibilidade são dotados de tamanha utilidade que podem, por um aspecto, serem considerados bens coletivos, a despeito de utilizados individualmente em partes perfeitamente segregadas. Nessa categoria Fabio Nusdeo insere a Justiça, enquanto "atividade jurisdicional ou aparato judiciário", eis que é disponibilizada a todos, e nesse sentido é um bem coletivo, mas é utilizada de forma parcelada e exclusiva por todos aqueles que dela necessitem para resolver conflitos, assumindo, nesse aspecto, feições de bem exclusivo ${ }^{7}$.

Ainda tratando da interface entre bens exclusivos e coletivos, casos há em que o uso de bens exclusivos acaba tornando-os bens coletivos. A despeito do seu uso ser individual, gera externalidades que os inserem em um novo nível, coletivo. Por mais que vacinas sejam aplicadas individualmente, dotando-se-lhes de uma feição exclusiva, o seu emprego em parcela considerável da população tem por efeito a diminuição dos casos da enfermidade transmissível combatida, diminuindo os riscos de contágio também na população não vacinada, gerando um benefício coletivo com a redução dos riscos de uma epidemia. Sob essa perspectiva, seria um bem coletivo ${ }^{8}$.

Transpondo essa correlação para a esfera dos interesses, tendo em consideração a relação entre interesse mediato e imediato, pode o indivíduo atuar na determinação de um interesse imediato que lhe seja individual, mas que também sirva como interesse mediato para um interesse coletivo, invariavelmente usufruído de forma coletiva pelos membros do grupo. Carnelutti os classifica como interesses individuais por sua modalidade e coletivos por sua finalidade ${ }^{9}$. Por mais que o interesse da defesa do território seja coletivo, o seu desenvolvimento depende de diversos interesses individuais mediatos, como a existência de soldados, quartéis, armas e equipamentos ${ }^{10}$. Nessa seara, a atuação de um indivíduo no

\footnotetext{
${ }^{7}$ NUSDEO, 1997, p. 45.

${ }^{8}$ NUSDEO, 1997, p. 188.

${ }^{9}$ CARNELUTTI, 2000, p. 60.

${ }^{10}$ A esse respeito, para Rodolfo de Camargo Mancuso, "A natureza de um interesse advém da finalidade à qual ele está afetado, e não da forma escolhida para o seu exercício" (MANCUSO, 2004, p. 28).
} 
desenvolvimento de um interesse coletivo favorece todo o grupo. Nessa condição, atua o indivíduo como um órgão da coletividade.

Concebendo-se o interesse coletivo como aquele que diz respeito a bens coletivos, não se exige para sua caracterização o móvel subjetivo de busca de satisfação de necessidades alheias ou do grupo. Um indivíduo pode egoisticamente almejar a satisfação de uma sua necessidade obtendo um bem que, por sua natureza coletiva, proporcione vantagens a outros sem que essa tenha sido sua intenção. $O$ sujeito que contrata uma empresa de segurança para vigiar a sua residência, por exemplo, acaba também beneficiando os moradores das residências vizinhas, desencorajando criminosos de atuarem na região. Sob a perspectiva do interesse coletivo como o agrupamento de interesses individuais com base em um sentimento de coletividade, é possível concebê-lo em casos em que a satisfação de uma necessidade individual não dependa de um bem coletivo. Um sujeito acometido de uma enfermidade rara ao invés de buscar o remédio para o tratamento apenas do seu caso pode, unindo-se a outros, vir a pleitear do Estado a implementação de uma política pública visando a disponibilização na rede pública de tratamento gratuito a todos e quaisquer indivíduos que apresentem a mesma enfermidade.

Não parece despropositado o entendimento de que ambos os casos contemplam interesse coletivo. No primeiro a satisfação do interesse pessoal é instrumental para o interesse coletivo, no segundo o coletivo é meio para o atendimento do interesse pessoal.

Outras caracterizações do interesse coletivo são desenvolvidas, sempre explorando a sua interface com os interesses individuais. Segundo Rodolfo de Camargo Mancuso, a distinção entre interesses individuais e coletivos residiria na amplitude de seu referencial. O interesse individual seria identificável pelo critério do elemento predominante, definindo-se como "o interesse cuja fruição se dá no círculo de atuação de seu destinatário, de forma precípua e imediata" ${ }^{11}$. Interesses coletivos se apresentariam de três formas distintas: como interesse pessoal do grupo; a soma de interesses ou a síntese de interesses $^{12}$.

\footnotetext{
${ }^{11}$ MANCUSO, 1989, p.168.

${ }^{12}$ MANCUSO, 1989, p.168.
} 
Assim é que o termo é empregado para designar o interesse pessoal de um grupo, distinto do interesse de seus membros, encontrando fundamento na organização dessa coletividade em uma "pessoa moral" ${ }^{13}$ capaz de manter interesses próprios e autônomos. A sua defesa dar-se-ia como um interesse individual de titularidade da entidade coletiva. Um sindicato que teve sua sede invadida é possuidor do interesse de ser reintegrado na posse do imóvel. De forma semelhante, uma sociedade empresária tem interesse na reparação de um bem que faz parte dos seus ativos e que fora danificado por ato de terceiro ${ }^{14}$.

Também se emprega a expressão como referência a um conjunto de interesses individuais agrupados. Aqui o interesse é coletivo apenas na forma em que é exercido, mas não na sua essência. Esses interesses justapostos conservam sua natureza individual, não se transmutando simplesmente por serem manejados coletivamente. $\mathrm{O}$ grupo funciona como um representante coletivo desses interesses individuais, que de outro modo poderiam perfeitamente ser tratados separadamente uns dos outros.

Para Mancuso, todavia, o uso mais apropriado da expressão designa o interesse resultante da operação de síntese de interesses individuais, e não de sua somatória ${ }^{15}$. Para o autor, "os interesses ficam afetados a um ente coletivo, nascido a partir do momento em que certos interesses, atraídos por semelhança e harmonizados pelo fim comum, se amalgamam: é síntese, antes que mera soma." ${ }^{16}$. Esse processo teria por base a aproximação de pessoas em situações sociais homogêneas em grupos representativos, que, entretanto, não representariam apenas os interesses aglutinados daqueles seus membros, mas sim o interesse sintetizado de todos aqueles que se encontrem na mesma posição, o que pode compor uma classe ou categoria ${ }^{17}$.

O que se nota, assim, é que, tanto sob o entendimento pelo qual se confunde o interesse coletivo com a aglutinação de interesses individuais, quanto sob a compreensão de ser ele

\footnotetext{
${ }^{13}$ MANCUSO, 1989, p.168.

${ }^{14}$ No que toca ao interesse público, como se observará adiante, esse interesse corresponderia ao interesse secundário do aparato estatal na classificação de Renato Alessi.

15 Para Cristiane Derani, o interesse coletivo não deve ser concebido como a mera soma dos interesses individuais egoístas, eis que, na verdade, o individual e o coletivo se contrapõem na sociedade moderna. (DERANI, 2002, p. 51).

${ }^{16}$ MANCUSO, 1989, p.168.

${ }^{17}$ Vale aqui notar que o processualista associa o interesse coletivo com uma forma de organização social que se reúne em torno dele. Na prática, contudo, constatam-se interesses coletivos que não são representados por grupos organizados sem que, com isso, percam sua natureza transindividual.
} 
dotado de uma natureza sui generis que o diferenciaria de tal simples somatória, pressupõe-se que todo interesse coletivo tenha uma expressão na esfera individual dos sujeitos. Da mesma forma que no muro encontram-se tijolos, que são os seus componentes, no pão encontra-se o trigo, ainda que combinado com outros ingredientes e deles não podendo ser desassociado ${ }^{18}$. Não há de se olvidar que o ser humano é o único a experimentar necessidades, de forma que a referência última dos interesses, ainda aqueles coletivos, seja o ser humano. Mesmo que não se classifique essa dimensão individual dos interesses coletivos de interesses individuais, não há como negar a sua existência, havendo quem a caracterize como interesses pessoais ${ }^{19}$.

Fato é que muitos interesses coletivos apresentam especial relevância para o ser humano, e, por esse motivo, são reconhecidos pelo Direito. Se a percepção e o enaltecimento jurídicos dos interesses individuais se deu precipuamente por intermédio do instituto do direito subjetivo, os interesses coletivos tradicionalmente se encontram representados no mundo jurídico pelo instituto do interesse público, e expressões que são a ele comumente associadas, especialmente interesse social e interesse geral. Interessante notar, todavia, que enquanto os interesses individuais são juridicizados tendo em vista os conflitos com que podem entrar em conflito, os interesses coletivos são juridicizados como interesse público para viabilizar o seu atendimento por laços de solidariedade por intermédio do Estado. Os espaços dos exercícios desses interesses se distinguiam: os interesses individuais pertenciam à esfera do direito privado e os coletivos identificados como interesse público à esfera do direito público, formando a clássica dicotomia público-privado.

\subsection{INTERESSE SOCIAL, INTERESSE GERAL E INTERESSE PÚBLICO}

Tratando dos conceitos de interesse social, público e geral, Rodolfo de Camargo Mancuso afirma compartilharem a característica da metaindividualidade, ou seja, de serem

\footnotetext{
${ }^{18}$ Caso contrário os alérgicos a trigo não teriam reação adversa ao consumo de pão.

19 Interesse pessoal é dessa forma usado por Carlos Alberto de Salles para, por exemplo, referir-se às diferentes intensidades que um interesse difuso pode ser experimentado por diferentes pessoas. Para Carlos Alberto de Salles: "De forma diversa, em algumas situações, tendo em vista a indivisibilidade do objeto da proteção jurídica, o resultado perseguido individualmente favorece interesses coletivos. A cessação de uma atividade nociva, por exemplo, obtida pela ação judicial de um vizinho incomodado, pode representar o término de situação lesiva para o meio ambeinte, em geral atendendo aos correspondentes interesses difusos." (SAlLES, Carlos Alberto de. Execução Judicial em Matéria Ambiental. São Paulo: Revista dos Tribunais, 1999, p. 89).
} 
"transcendentes ao indivíduo isoladamente considerado" ${ }^{20}$. Na visão do autor, apesar do seu conteúdo deveras aproximado, sendo tais expressões em muitas hipóteses utilizadas indistintamente, apresentam nuances que as distinguem, as quais, contudo, não seriam capazes de lhes dar completa autonomia conceitual ${ }^{21}$.

Segundo Mancuso, interesse social designa dois objetos distintos. Um, mais restrito, concernente ao interesse atribuído a uma pessoa jurídica, entendida como "uma universidade de bens e pessoas afetadas a um objetivo adrede estabelecido por seus integrantes". Nesse sentido, o interesse social nada mais seria do que interesses individuais dos seus membros exercidos coletivamente por intermédio da pessoa moral. A circunstância de um interesse individual ser exercido de forma coletiva não lhe alteraria a natureza, mantendo seu caráter individual. Para o autor, o que qualifica um interesse é a sua finalidade e não a forma do seu exercício. Se o que se busca é uma posição de vantagem para a pessoa natural ou jurídica, sem preocupações metaindividuais, o que se teria em evidência é um interesse individual. Sob essa acepção, o interesse comercial perseguido por uma empresa é social, porque exercido coletivamente, mas individual na sua essência, eis que visa, em última instância, ao lucro.

O outro significado, mais amplo, diz respeito ao interesse da sociedade civil, entendida como "o contingente populacional organizado como nação", confundindo-se com o que se entende por bem comum, de acordo com aqueles valores escolhidos por uma dada sociedade como mais relevantes. Aqui, trata-se de interesse coletivo exercido coletivamente, em muito semelhante ao uso que se dá a "interesse geral"22.

Alf Ross apresenta entendimento diverso do que vem a caracterizar interesse social, partindo da perspectiva individual - porquanto para ele essa é a única verdadeira forma de formação de interesses - e diferenciando-o do interesse comunitário. Para o autor dinamarquês, ao se examinar a realidade, constata-se que os homens dependem invariavelmente uns dos outros, estabelecendo-se múltiplas relações de interdependência, numa solidariedade fatual. Assim, há relações de dependência entre capital e trabalho, entre a prosperidade da agricultura e das indústrias, entre a estabilidade econômica de

\footnotetext{
${ }^{20}$ MANCUSO, 2004, p. 25.

${ }^{21}$ MANCUSO, 2004, p. 36.

${ }^{22}$ MANCUSO, 2004, p. 29.
} 
diferentes países. Essas ligações de interesses que impregnam a vida humana levam à cooperação, a qual acaba por gerar ainda maior grau de interdependência. Chega-se a considerar tais interesses como comuns, experimentados por coletividades.

Nesse tocante, caracterizam-se a sociedade e a comunidade como duas formas de vida social, sendo a primeira marcada pelas ligações dos interesses dos seus membros, uns dependentes dos outros, e a segunda pela predominância do sentimento de simpatia e de integração ao grupo. Enquanto interesses sociais se revelariam teoricamente, no plano fático, os interesses comunitários dependem de um elemento subjetivo de identificação com o grupo, de altruísmo, com rejeição aos interesses egoístas em detrimento do todo ${ }^{23}$.

Não existe uma contraposição necessária entre interesses sociais e individuais. Situações há em que interesses podem ser considerados em duas dimensões, encontrando-se, em uma, individualmente isolados, e, em outra, socialmente ligados. A propriedade de um bem por um indivíduo representa um interesse individual em conflito com o de outros sujeitos, eis que estes ficarão privados de aludido bem. Ao mesmo tempo, contudo, a todos interessa a existência de um ordenamento da propriedade que proporcione a cada um a segurança da posse. Assim, aquele interesse individual a respeito do qual os demais podem ser indiferentes ou opostos, em outra esfera caracteriza um interesse social ${ }^{24}$.

Para Alf Ross, a distinção conceitual entre interesses individuais e sociais marca a base da identificação de interesses privados e interesses públicos. Enquanto interesses individuais caracterizam interesses privados, os interesses públicos "são interesses sociais protegidos pelo Estado como expressão dos órgãos politicamente organizados do poder da comunidade" 25 . Apesar desse conceito abranger os interesses individuais derivados de que as autoridades públicas são incumbidas em conexão com a proteção dos interesses públicos em sentido geral, prefere Alf Ross designá-los de interesses do Estado ${ }^{26}$.

Assim como interesse e direito subjetivo, interesse público também é um lugar-comum, de acordo com Tércio Sampaio Ferraz Junior. Nessa condição, é empregado indistintamente

\footnotetext{
${ }^{23}$ ROSS, 2003, pp. 413/414.

${ }^{24}$ ROSS, 2003, p. 414.

${ }^{25}$ ROSS, 2003, p. 415.

${ }^{26} \mathrm{O}$ qual teria certo grau de semelhança com o conceito de interesse secundário de Renato Alessi, conforme exposto mais adiante.
} 
por operadores e estudiosos do direito nada obstante inexistir uma definição uníssona para o conceito. Mesmo com as inúmeras conceituações de interesse público disseminadas, o seu uso eficiente é viabilizado por em volta dele se erigir uma espécie de aceitação silenciosa, sem dar azo a maiores questionamentos. "Lugares comuns não se definem e é por isso mesmo que são lugares comuns, como tais, expressões abertas, difusas e, assim, aceitáveis por muitos, independentemente de divergências quanto a detalhes" 27.

Comprovando tal assertiva, Marçal Justen Filho aponta três linhas doutrinárias objetivando sua conceituação. A primeira caracteriza -o como o interesse privado comum e homogêneo da totalidade ou de grande parte da sociedade, diferenciando-se o interesse privado do público apenas no aspecto quantitativo, mas não no qualitativo eis que qualquer espécie de interesse privado poderia vir a configurar interesse público.

A segunda distingue duas categorias de interesses privados, uma que congrega interesses individuais de cunho egoístico que não teriam a feição de qualificar-se como interesse público, e outra que diz respeito a interesses que transcendem a individualidade e que possam vir a constituir interesse público desde que configurada a "homogeneidade coletiva" e a titularidade da maioria. Uma variante de tal vertente apregoa que alguns interesses privados, em razão de sua relevância especial, possam vir a assumir a natureza de interesse público mesmo não sendo compartilhados pela maioria.

A última identifica o interesse público como o interesse da sociedade, do todo, que não se confunde com a mera somatória dos indivíduos. Vê-se a sociedade como uma instituição que supera e transcende os indivíduos que a compõe, seja no espaço ou no tempo, eis que mudanças na sua composição individual, como, por exemplo, em razão da morte, não lhe afetam a identidade.

A aproximação semântica entre interesse público, interesse geral e bem comum é frequente e insere-se em um contexto histórico, assunto explorado por Maria Sylvia Zanella Di Pietro, partindo da distinção entre interesses individuais e gerais na antiguidade grecoromana.

\footnotetext{
27 FERRAZ JUNIOR, Tercio. $\quad$ Interesse $\quad$ Público. http://www.terciosampaioferrazjr.com.br/?q=/publicacoes-cientificas/31 acessado em 10 de dezembro de 2013.
} 
Aristóteles propugnava que a totalidade é mais do que a mera justaposição dos fins dos indivíduos que a compõem. O bem da totalidade, desse modo, seria alcançado não pelo esforço individual desses componentes visando seu próprio bem de forma antagônica, mas sim pela contribuição solidária de todos almejando o bem comum em conformidade com as regras vigentes na comunidade. O bem comum, por sua vez, levaria ao bem dos membros da totalidade. A bondade humana residiria na atuação em prol desse bem comum, em contraposição à perseguição de fins próprios individuais.

Na Idade Média, sob influência do cristianismo, a ideia de bem comum tomou corpo com São Tomás de Aquino, para quem tudo aquilo que o homem busca como objeto de desejo, seja de qual natureza for, configura o bem comum, pois, por qualificar-se como um ser social, o homem almeja além do seu próprio bem, o dos grupos do qual faz parte. O bem comum a ser perseguido pelo Estado configura condições comuns para a organização e conservação dos bens dos particulares, apesar de no aspecto formal se distinguir das partes; bem como constitui o fim e a forma da conjugação dos indivíduos em sociedade. A solidariedade social era vista como a razão da vida em sociedade.

Com o contratualismo e liberalismo dos séculos XVII e XVIII essas concepções mudam, migrando-se o foco da coletividade para o indivíduo. Com Locke, a justificativa para a congregação do homem em sociedade deixa de ser vista como a consecução de objetivos comuns, passando a ser examinada como expressão da busca de interesses privados individuais que melhor se desenvolveria com a vida em sociedade, proporcionando as sujeitos melhores condições do que na anarquia. A Revolução Francesa representa a firmação do individualismo, reconhecendo-se os direitos de igualdade e liberdade como ínsitos ao homem de tal forma a não poderem ser dele destituídos. Nesse contexto, a união do homem em sociedade serve para assegurar que se respeitem o espaço de liberdade individual de cada um, servindo também a lei - expressão da vontade geral - a esse objetivo.

No contratualismo, a concepção de bem comum, com sua carga moral e ideológica, sucumbe à noção de interesse geral, de natureza utilitarista. A diferença terminológica corresponderia a uma mudança de perspectiva: o bem geral indica fins honestos e o 
interesse geral, fins úteis ${ }^{28}$. O homem se dispõe a associar-se com os demais, mediante o contrato social, para por meio dessa união obter vantagens individuais. Para Hobbes, o atendimento do interesse geral se alcança mediante a satisfação dos interesses individuais, inexistindo diferença na natureza entre ambos ${ }^{29}$. Rousseau, de outra forma, distingue uns dos outros, considerando assumirem a liberdade e a igualdade nova configuração no estado social, eis que todos se submetem à vontade geral ${ }^{30}$, sofrendo limitações, mas recebendo cada um parte indivisível do todo. Sob a perspectiva de Rousseau, a lei congrega a expressão da vontade de todos, encontrado o Estado legitimidade no consentimento, no interesse geral que passa a incorporar ${ }^{31}$. A lei deve cristalizar apenas e tão somente a vontade geral, não devendo extrapolar esse limite para não violar as liberdades individuais.

Nessa linha, Cristiane Derani aponta a existência de duas concepções de interesse público na história do direito administrativo. Uma, de cunho utilitarista, pela qual significa a soma dos interesses dos particulares, sujeitando-se a críticas pela impossibilidade de se extrair da sociedade um interesse que congregue o de todos. A outra, de modo diverso, tem-no como algo que supera a esfera dos interesses particulares, aludindo ao interesse de grupo e representando a vontade geral, mas também encontrando dificuldades em razão dessa vontade geral não significar a vontade de todos, eis que esta pressupõe que todos os membros da sociedade sejam idênticos, inexistindo essa igualdade em termos materiais. Para a autora, assim, nenhuma das concepções tradicionais de interesse público é capaz de dar resposta às necessidades da sociedade moderna ${ }^{32}$.

\footnotetext{
${ }^{28}$ DI PIETRO, Maria Sylvia Zanella. Discricionariedade Administrativa na Constituição de 1988. 2. ed. São Paulo: Atlas, 2007, pp. 88/89.

${ }^{29}$ Hobbes expõe uma visão individualista do homem, mas seus interesses dizem mais respeito à honra, sob a ótica da sua reputação perante terceiros, do que a bens materiais. A vida em sociedade se justificaria para prevenir o estado natural de guerra inerente à coexistência humana na natureza. Para isso, cada homem abriria mão do seu direito irrestrito a todas as coisas, do qual se julga titular no estado de guerra. A sociedade, em última instância, justificaria-se para satisfazer seu interesse pessoal de evitar os males associados ao estado de guerra. (WEFFORT, Francisco (Org.). Os Clássicos da Política, $1^{\circ}$ vol. 5. ed. São Paulo: Ática, 1995, pp. 54/61).

30 "Essas cláusulas, bem entendidas, reduzem-se todas a uma só: a alienação total de cada associado, com todos os seus direitos, à comunidade toda, pois, em primeiro lugar, desde que cada um se dê completamente, a condição é igual para todos e, sendo a condição igual para todos, ninguém se interesse a torná-la onerosa aos demais." (WEFFORT, 1995, p. 220).

31 "Há comumente muita diferença entre a vontade de todos e a vontade geral. Esta se prende somente ao interesse comum; a outra ao interesse privado e não passa de uma soma das vontades dos particulares. Quando se retiram, porém, dessas mesmas vontades, os excessos e as faltas que nela se destroem mutuamente, resta como soma das diferenças, a vontade geral." (WEFFORT, 1995, p. 228).

${ }^{32}$ DERANI, 2002, p. 49.
} 
Assim é que, com o Estado Social de Direito, num contexto de desigualdades sociais, retoma o conceito de interesse público carga axiológica, associando-se-o com a ideia de bem comum, não mais sob perspectiva utilitária, mas com preocupações em proporcionar condições para a garantia de metas e valores reconhecidos socialmente, todos sob o primado da dignidade da pessoa humana ${ }^{33}$. No Brasil, a Constituição de 1988 filiou-se a esse ideário, decretando o Estado Democrático de Direito, tendo dentre seus fundamentos a dignidade da pessoa humana e elencando dentre seus objetivos a constituição de uma sociedade livre, justa e igualitária.

Nesse percurso histórico, outra mudança é apontada por Marçal Justen Filho. De início, ao interesse público era atribuída uma natureza eminentemente técnica. Seria ele assim reconhecido para que pudesse ser implementado pelo Estado em razão da inviabilidade de sua consecução por meios particulares no bojo da sociedade civil. No transcurso do século $\mathrm{XX}$, entretanto, por consequência dos processos de geração e acumulação de riqueza, a sociedade civil passou a contar com entidades aptas a satisfazer as necessidades que baseiam interesses dessa espécie, possuindo recursos materiais e técnicos por vezes até superiores a entidades estatais. Daí até porque ter o Estado passado a contar com a atuação de entidades privadas para o desenvolvimento de obras e prestação de serviços públicos. Nesse cenário, a natureza do interesse público deixa de ser puramente técnica e passa a ser ética. A preocupação maior não reside na viabilização da satisfação de interesses individuais pelo Estado, mas sim pela obrigação ética de não deixar nenhum de tais interesses desatendido, eis que relacionados a princípios e valores fundamentais, especialmente o da dignidade da pessoa humana ${ }^{34}$.

\footnotetext{
33 "Com o Estado Social, o interesse público a ser alcançado pelo direito administrativo humaniza-se na medida em que passa a preocupar-se não só com os bens materiais que a liberdade de iniciativa almeja, mas com valores considerados essenciais à existência digna; quer-se liberdade com dignidade, o que exige maior intervenção do Estado para diminuir as desigualdades sociais e levar toda a coletividade o bem-estar social. $\mathrm{O}$ interesse público, considerado sob o aspecto jurídico, reveste-se de um aspecto ideológico e passa a confundir-se com a ideia de bem comum." (DI PIETRO, 2007, p. 94). Carlos Alberto Salles também nota essa mudança na concepção do interesse público com o surgimento do Estado Social: "Sob pressupostos estritamente liberais, a função do direito está em salvaguardar as autonomias individuais. Sob essas premissas, os objetivos da sociedade surgem da soma das vontades individuais. Com o advento do Estado social o próprio direito passa a incorporar objetivos sociais, os quais não são mais a simples soma das autonomias individuais, mas metas e valores definidos a priori pelos vários processos decisórios da sociedade." (SALLES, Carlos Alberto de. Processo Civil de interesse público: uma nova perspectiva metodológica. SUNDFELD, Carlos Ari; BUENO, Cassio Scarpinella (coordenadores). Direito Processual Público: a Fazenda Pública em Juízo. São Paulo: Malheiros, 2000, p. 49).

34 "Modernamente, o conceito de interesse público não se constrói a partir da impossibilidade técnica de os particulares satisfazerem determinados interesses individuais, mas pela afirmação da impossibilidade ética de deixar de atendê-los." (JUSTEN FILHO, Marçal. Conceito de Interesse Público e a Personalização do Direito Administrativo. In: Revista Trimestral de Direito Público, 26/1999, p. 124).
} 


\subsection{INTERESSE PÚBLICO E O ESTADO}

A relevância do interesse público, especialmente em comparação com as outras acepções generalizantes dos interesses transindividuais, refere-se à sua associação com o Estado ${ }^{35}$. O conceito tradicionalmente remete à figura estatal. Essa associação encontra fundamento no fato de tradicionalmente caber ao Poder Público indicar o conteúdo do interesse público, bem assim estabelecer sua ordenação normativa e satisfazê-lo ${ }^{36}$. A atuação do Estadoadministração se legitima enquanto tem por finalidade o atendimento do interesse público, sob pena de configurar desvio de poder. E cabe ao Estado, em todas as suas manifestações, encontrar, no universo de interesses existentes, aqueles mais relevantes, em sintonia com os valores prevalecentes na sociedade para persegui-los como interesse público ${ }^{37}$. Sua atuação nesse sentido constitui um poder-dever ${ }^{38}$.

Nada obstante sua relevância para todos os segmentos do direito público, uma vez que a atividade administrativa é a que pronuncia de forma mais presente e constante a atuação estatal, o conceito de interesse público assume papel central para o Direito Administrativo, funcionando como instrumento, limite e fundamento do poder do Estado. Instrumento, pois a supremacia do poder público permite ao Estado fazer-se prevalecer sobre os interesses privados. Limite, porquanto vincula a atuação estatal ao que possa ser considerado de finalidade de interesse público. Fundamento, porque é elemento de legitimação do poder, justificando a restrição da liberdade dos indivíduos pelo Estado, eis que qualquer ação na esfera pública se justificaria enquanto relacionada a interesses gerais, benefícios coletivos, necessidades sociais ${ }^{39}$.

Assim é que se caracteriza o Direito Administrativo, por um lado, pelas prerrogativas e privilégios concedidos à Administração Pública com a finalidade de fazer promover o bem

\footnotetext{
${ }^{35}$ Isso não quer dizer que todo interesse do Estado seja, ipso facto, um interesse público, pondo-se em relevo, a esse respeito, a distinção entre interesses primário e secundário desenvolvida mais adiante (BANDEIRA DE MELLO, 2011, p. 62).

${ }^{36}$ MANCUSO, 2004, p. 31.

${ }^{37}$ MANCUSO, 2004, p. 32.

${ }^{38}$ FIGUEIREDO, 2008, p. 35.

39 Daí porque a aproximação semântica do conceito de interesse público e interesse geral (MARQUES NETO, Floriano Peixoto de Azevedo. Regulação Estatal e Interesses Públicos. São Paulo: Malheiros, 2002, pp. 77/79).
} 
geral $^{40}$, e, de outro, pelas restrições impostas a fim de preservar a esfera de liberdades individuais, ressaltando-se, a esse respeito, o princípio da legalidade ${ }^{41}$.

A relevância do interesse público é tamanha, que Celso Antônio Bandeira de Mello põe os princípios da supremacia do interesse público sobre o particular e da indisponibilidade do interesse público como centrais a fundamentar, dar sentido e aglutinar todos os demais princípios de Direito Administrativo (e.g., legalidade, isonomia, inalienabilidade, controle judicial) ${ }^{42}$. O reconhecimento da supremacia do interesse público importa afirmar o caráter instrumental dos poderes do Estado e dos agentes públicos, orientando-se o seu exercício necessariamente para a realização do interesse público ${ }^{43}$.

De fato, a associação é tão visceral que não é incomum identificar-se de forma equivocada o interesse público com o interesse do Estado ${ }^{44}$. Além da circularidade teratológica que tal equiparação implica, eis que o interesse seria do Estado por ser público e seria público por ser do Estado, dá azo a dois outros problemas. Em primeiro lugar, porque tal interesse não se identifica pelo seu titular, mas precipuamente pelo seu conteúdo. Em segundo lugar, porque não é o Estado titular do interesse público, porquanto este a ele não pertence, por mais que lhe cumpra o papel de persegui-lo. Afirmar que o interesse é público por ser de titularidade estatal representaria uma "inversão lógica e axiológica", pois o Estado é instrumento de realização do interesse público, de forma que a sua consecução só lhe é atribuída por ser o interesse público, e não o inverso ${ }^{45}$. O objeto não pode ser definido em razão do seu instrumento.

A distinção entre interesse público e interesse do Estado é realizada por meio da famosa classificação de autoria de Renato Alessi, separando o interesse público primário do

40 "A defesa do interesse público corresponde ao próprio fim do Estado. O Estado tem que defender os interesses da coletividade. Tem que atuar no sentido de favorecer o bem-estar social. Para esse fim, tem que fazer prevalecer o interesse público em detrimento do individual, nas hipóteses agasalhadas pelo ordenamento jurídico. Negar a existência do princípio da supremacia do interesse público é negar o próprio papel do Estado." (DI PIETRO, 2007, pp. 96/97).

${ }_{41}$ São os princípios da supremacia do interesse público e o da legalidade os basilares do direito administrativo. (DI PIETRO, 2007, p. 93).

${ }^{42}$ BANDEIRA DE MELlO, Celso Antônio. Curso de Direito Administrativo. 28. ed., São Paulo: Malheiros, 2011, pp. 55/58.

${ }^{43}$ JUSTEN FILHO, 1999, p. 115.

${ }^{44}$ Nesse sentido, afirma Maria Sylvia Zanella di Pietro que "A Administração Pública não é a titular do interesse público, mas apenas a sua guardiã; ela tem que zelar pela sua proteção. Daí a indisponibilidade do interesse público." (DI PIETRO, 2007, p. 222). Apesar de lhe atribuir relevância coletiva, há quem entenda ser o Estado o titular do interesse público (BANDEIRA DE MELLO, 2011, p. 74).

${ }^{45}$ JUSTEN FILHO, 1999, pp. 116/117. 
interesse secundário. O primeiro caracteriza o verdadeiro interesse público, coincidindo com aquela noção de interesse da coletividade que constitui fonte de legitimidade da atuação do Poder Público. Interesse secundário, de outro modo, consiste o interesse próprio do aparato da Administração Pública, do Estado enquanto sujeito de direito, não mantendo uma necessária correspondência com aquele interesse coletivo. A esse respeito, à Administração Pública é dado perseguir o interesse secundário somente e na medida em que coincidente com o primário ${ }^{46}$. Celso Antonio Bandeira de Mello, aludindo à doutrina de Alessi, afirma que isso poderá se dar se a norma qualificar tal interesse secundário como instrumental para o atendimento do primário, caso em que a sua defesa representará também defesa do interesse público ${ }^{47}$.

Para Marçal Justen Filho o interesse do Estado enquanto aparato estatal sequer qualificaria interesse na acepção jurídica do termo, mas meras "conveniências circunstanciais, alheias ao Direito". Isso porque o Estado não foi instituído para a obtenção de vantagens próprias, mas apenas para o favorecimento do bem comum. Assim, não lhe seria dado possuir interesses egoísticos próprios, como sói ocorrer com os particulares ${ }^{48}$.

\footnotetext{
46 "Estos intereses públicos, colectivos, cuya satisfacción está a cargo de la Administración, no son simplemente el interés de la Administración entendida como aparato organizativo, sino lo que se ha llamado el interés colectivo primario, formado por el conjunto de intereses individuales preponderantes en una determinada organización jurídica de la colectividad, mientras que el interés del aparato (si es que puede concebirse un interés del aparato unitariamente considerado) sería simplemente uno de los intereses secundarios que se hacen sentir en la colectividad, y que pueden ser realizados solamente en caso de coincidencia con el interés colectivo primario y dentro de los limites de dicha coincidencia. La peculiaridad de la posición jurídica de la Administración pública radica precisamente en esto, en que su función consiste en la realización del interés colectivo, público, primario" (ALESSI, Renato. Instituciones de Derecho Administrativo. Tradução de Buenaventura Pellisé Prats, Tomo I, Barcelona: Bosch, 1970, pp.184/185). Em uma dada coletividade social desponta uma densa rede de interesses, que entre si estabelecem relações, seja de conflito seja de coincidência. Renato Alessi, com suporte na doutrina de Leopoldo Piccardi, aduz ser individual aquele interesse experimentado por um indivíduo, mas se esse mesmo interesse for experimentado por uma coletividade de indivíduos passará a ser um interesse coletivo, entendido como a expressão unitária de uma multiplicidade de interesses individuais coincidentes. A organização jurídica de uma dada coletividade representa a eleição de um conjunto de interesses coletivos no universo de interesses, coletivos e individuais, que permeia aludida coletividade. Chama-se interesse coletivo primário o conjunto desses interesses coletivos eleitos, distinguindo-se dos interesses individuais dos membros da coletividade, podendo estes ser coincidentes ou conflitantes com aquele. Aos interesses individuais dos membros da coletividade dá-se o nome de interesses secundários. A satisfação do interesse coletivo primário pode se dar de forma direta, tutelado independentemente dos interesses secundários, ou de forma indireta, por decorrência da satisfação desses interesses secundários que com ele sejam coincidentes. Nesse contexto, o interesse público se confundiria com o interesse coletivo primário sujeito à tutela direta pela atividade administrativa, enquanto o interesse da entidade organizada Administração Pública constituiria apenas um dos interesses secundários do grupo social. (ALESSI, 1970, pp. 184/185).

${ }^{47}$ BANDEIRA DE MELLO, 2011, p. 66.

${ }^{48}$ JUSTEN FILHO, 1999, p. 118.
} 
A par desses interesses primário e secundário, despontaria ainda o interesse individual daqueles sujeitos que ocupam os cargos públicos, vez que a Administração Pública é conduzida por pessoas - as quais, conforme visto, são insitamente centros de interesses. Para o atendimento desses interesses, contudo, não pode ser movimentada a máquina administrativa $^{49}$.

Como o agente público não age, ou pelo menos não deveria agir, nessa sua condição para o atendimento do seu próprio interesse, Cristiane Derane afirma que sua atividade é desinteressada, sendo-lhe imposta não como um direito, mas como um dever. $\mathrm{O}$ direito pertence à sociedade como um todo e tem por objeto o cumprimento desse dever orientado pelo interesse de toda a coletividade ${ }^{50}$.

O Estado não é, assim, titular do interesse público, mas tem o poder-dever de atendê-lo, de modo que, por ambos os motivos, não lhe é dado dispor de tais interesses, concebendo-se, a esse respeito, o princípio da indisponibilidade do interesse público.

Nada obstante não configure propriamente um interesse do Estado, é inegável se tratar de um interesse estatizado. Em virtude dessa sua condição, assume uma posição de vantagem com relação a interesses de outras naturezas. Considerando o universo dos interesses existentes, a qualificação de um como interesse público representa em dois sentidos o seu sobrepujamento sobre os outros. Em primeiro lugar, isso se dá porque ao ser definido como interesse público, torna-se qualificado a ser objeto de perseguição pelo Estado. O simples fato de ser encampado pelo Poder Público já é razão para encontrar-se em uma posição de vantagem, destacando-se daqueles que não podem motivar o exercício de atividades administrativas. Considerando os interesses nas interações de conflito que estabelecem, assume o Estado posição pró-ativa na resolução do conflito, não os deixando ao livre alvitre dos particulares. Diogo de Figueiredo Moreira Neto tece as seguintes considerações a esse respeito:

\footnotetext{
${ }^{49}$ Segundo Marçal Justen Filho, é "imprescindível distinguir e afastar, também, o interesse privado do sujeito que exerce função pública. $\mathrm{O}$ exercício da função pública não pode ser afetado pelos interesses privados e egoísticos do agente público. Eles continuam a ser interesses privados, submetidos às regras comuns, que disciplinam a generalidade dos integrantes da comunidade." (JUSTEN FILHO, 1999, p. 118).

${ }^{50}$ DERANI, 2002, p. 46.
} 
Enquanto os conflitos se travam entre pessoas, físicas ou jurídicas, da sociedade civil, o Estado intervém geralmente sob provocação, no vaso campo das relações sociais horizontais, regidas pelo Direito Privado. Quando os conflitos passam a comprometer interesses mais abrangentes, definidos pela própria ordem jurídica como interesses públicos, o Estado assume a condição de parte na relação, passando a atuar por direito próprio, mesmo ex officio, se necessário para compor as relações sociais regidas pelo Direito Público $^{51}$.

Em segundo lugar, beneficia-se também em função da aplicação do princípio que determina a precedência do interesse público sobre os interesses privados. Dele decorre que, nos casos de conflitos de interesses, aquele tido por público goza de uma predisposição a se sobrepor sobre os demais. Além de ter suporte no poder e recursos estatais, prevalece sobre os demais que com ele sejam incompatíveis. Ambos os aspectos serão abordados na sequência.

\subsection{A DETERMINAÇÃO DO INTERESSE PÚBLICO}

Considerando a importância do papel que lhe é atribuído, a definição do que vem a representar interesse público é tarefa da maior relevância, embora também proporcione enormes dificuldades. Extrair de um determinado contexto social o que vem a ser o interesse geral, o bem comum ou interesses individuais comuns com relevância social não é algo que se proceda com facilidade. O ente a que cabe realizar tal interpretação é o Estado, com base nos mecanismos democráticos que o legitimam a captar a vontade popular. E o instrumento próprio para veicular os valores, parâmetros e critérios advindos da vontade popular reside no Direito.

Daí porque se afirma ser o interesse público um conceito jurídico-positivo, ou seja, o seu conteúdo em cada caso concreto advém do próprio sistema jurídico, por mais que possam

\footnotetext{
${ }^{51}$ MOREIRA NETO, 2009, p. 10.
} 
lhe ser dadas política ou sociologicamente outras acepções em um dado momento histórico $^{52}$.

É a Constituição o primeiro instrumento a fornecer os parâmetros do que pode vir a ser interesse público, não por acaso também constituindo o fundamento de todo o ordenamento jurídico de um país. Como a ela não é dado descer às minúcias e contemplar na sua inteireza a variedade de situações concretas que podem se apresentar no cotidiano ${ }^{53}$, fixa os princípios e finalidades públicas, bem como as competências e processos para a definição normativa do interesse público pelo Legislativo e pelo Executivo ${ }^{54}$.

Com fundamento na Constituição, cabe à lei estabelecer o conteúdo e as limitações da atuação do poder político na consecução das finalidades coletivas que também nela veem prescritas. A definição legal do interesse público se relaciona com o princípio da legalidade ou da reserva legal reinantes na esfera do Direito Administrativo. À Administração Pública cabe apenas o atendimento do interesse público, tendo seu conteúdo definido na lei. Logo, a Administração Pública deve agir somente no que lhe determinar a lei. Por isso é que Lucia Valle Figueiredo afirma ser interesse público "aquilo que a lei quis" ou, " dentro de determinado ordenamento jurídico-positivo, é aquele a que a Constituição e a lei deram tratamento especial" ${ }^{\prime 5}$.

Como não pode a lei prenunciar todas as potenciais situações concretas do mundo da vida, nem sempre é capaz de orientar com exatidão a atuação do Poder Público no caso concreto. Nessas circunstâncias, o princípio da legalidade não se pronuncia de forma estrita, admitindo-se certo espaço de manobra para a Administração Pública, dotando-se-lhe de poderes implícitos e explícitos, bem assim de margem de discricionariedade para apurar e decidir segundo critérios de oportunidade e conveniência.

\footnotetext{
${ }^{52} \mathrm{O}$ interesse público apresenta diversas acepções, dotando-lhe de aparente caráter fluido. (FIGUEIREDO, 2008, p. 35)

${ }^{53}$ Casos há, entretanto, que é impossível identificar o interesse público diretamente na Constituição, sem a necessidade de recurso à outros diplomas normativos.

54 "Com efeito, dita qualificação quem faz é a Constituição e, a partir dela, o Estado, principalmente através dos órgãos legislativos, e depois por via dos órgãos administrativos, nos casos e limites da discricionariedade que a lei lhes haja conferido." (BANDEIRA DE MELLO, 2011, p. 68).

${ }^{55}$ FIGUEIREDO, 2008, p. 35
} 


\subsection{INTERESSE PÚBLICO COMO CONCEITO JURÍDICO INDETERMINADO}

As dificuldades de definição devem-se, em grande parte, pela sua natureza de conceito jurídico indeterminado. Essa sua natureza não constitui um defeito, mas atributo resultante de técnica para permitir a aplicação do conceito em uma vastidão de situações que surgem na realidade ${ }^{56}$. Por não se determinar com precisão os limites da sua definição, adequa-se o seu uso a casos concretos dos mais variados, incrementando-se sua funcionalidade.

Afirma-se, assim, que não é definível de forma genérica, universal e abstrata. Impassível de tomar uma formula aplicável a toda e qualquer hipótese ${ }^{57}$. Sua identificação dá-se, assim, caso a caso, tornando-se inevitável sua avaliação pragmática ${ }^{58}$. A questão que se coloca, assim, diz respeito à definição do que representa o interesse público em cada situação concreta. Daí dizer-se que sua formulação é indeterminada.

Carlos Alberto Salles reconhece a necessária abertura do conceito, para que possa compreender situações das mais diversas, criando um campo de interesses elegíveis muito vasto e que, no mais das vezes, entre si confrontam-se. Por conta dessa abertura, reconhece-se certo campo de discricionariedade ao Estado na tarefa de decidir a respeito dos interesses a serem erigidos a interesse público.

A questão, entretanto, está na identificação de um núcleo mínimo de significado, sem o qual o único critério para a definição do interesse público seria a definição da autoridade competente para identificá-lo. Sua abertura conceitual não significa que nele caibam todos e quaisquer interesses. De outro modo, seria um termo "oco" ${ }^{59}$. Fala-se assim na existência de um núcleo conceitual $^{60}$, a respeito do qual não restam dúvidas quanto a sua caracterização, bem assim um campo de exclusão no qual certamente o termo não se insere, existindo entre um e outro uma zona cinzenta. Lúcia Valle Figueiredo, a esse respeito, distingue uma zona de certeza positiva de uma zona de certeza negativa,

\footnotetext{
56 JUSTEN FILHO, 1999, p. 116.

${ }^{57}$ JUSTEN FILHO, 1999, p. 133.

${ }^{58}$ MARQUES NETO, 2002, pp. 84/85. Segundo Lúcia Valle Figueiredo, trata-se de conceito pragmático, que comporta mais de uma acepção, dependendo das disposições do texto normativo de do contexto em que será aplicado. Aos conceitos pragmáticos, opõem-se os teoréticos, que admitem apenas uma acepção. Tratase de classificação similar à dos conceitos indeterminados e determinados (FIGUEIREDO, 2008, p. 67).

${ }^{59}$ FIGUEIREDO, 2008, p. 67.

60 JUSTEN FILHO, 1999, p. 116.
} 
remanescendo entre uma e outra uma zona intermediária ou zona cinzenta em que se situa o problema ${ }^{61}$.

\subsection{O PROCESSO DE TRANSMUTAÇÃO DO INTERESSE PÚBLICO HOMOGÊNEO PARA OS INTERESSES PÚBLICOS HETEROGÊNEOS}

As dificuldades de identificação do interesse público apesar de sempre presentes, tornaram-se mais acentuadas com o Estado Social. O processo de positivação do interesse público, pelo qual se considera o interesse público aquilo e nada mais do aquilo fixado em lei, revelou a absolutização do conceito marcada a partir do Absolutismo, com o monopólio da produção do Direito pelo legislador, e firmada no Liberalismo. Cabendo ao Estado Liberal funções mínimas de garantir as liberdades públicas, a definição legal do conteúdo do interesse público lei não implicava grande complexidade, eis que se lhe atribuía a finalidade de assegurar as liberdades individuais intervindo minimamente na esfera da autonomia privada ${ }^{62}$.

Com o intervencionismo estatal que marca o Estado Social, do Bem Estar Social ou Democrático de Direito, assumiu o Estado uma pluralidade de novas funções, sobretudo de cunho social, levando ao crescimento exponencial da atividade administrativa. Nesse contexto, a fixação do interesse público passou a se tornar tarefa mais complexa, demandando a eleição e o prevalecimento de interesses concretos de parcelas da coletividade. Por mais que a lei mantivesse a função de definir as balizas para a conformação do interesse público, tornou-se inevitável conceder ao agente político margem de discricionariedade de maior abrangência para decidir quais interesses configurariam o interesse público no caso concreto.

\footnotetext{
${ }^{61}$ FIGUEIREDO, 2008, p. 217.

${ }^{62}$ Tradicionalmente caracterizam-se as liberdades públicas, ou direitos fundamentais de primeira dimensão, como direitos negativos, que pouco mais requerem do que a abstenção do Estado em violá-los. Examinando o assunto sob outra perspectiva, há certa razão em quem sustenta que a efetividade de tais direitos demanda uma considerável atuação estatal. Para que se garanta o direito do propriedade, por exemplo, exige-se a implementação e manutenção de um sistema de segurança pública, tribunais, sistema penitenciário, com todos os recursos materiais e humanos a eles atinentes. Nesse sentido, José Afonso da Silva afirma: "Entendida como autolimitação estatal em benefício de determinadas esferas privadas, tal categoria acha-se superada pela própria dinâmica econômico-social de nosso tempo, em que o desfrute de qualquer direito fundamental exige atuação ativa dos poderes públicos." (SILVA, José Afonso da. Curso de Direito Constitucional Positivo. 16. ed. rev. e atual. São Paulo: Malheiros, 1999, p. 181).
} 
Certos campos em que pudesse exercer suas atividades de forma discricionária sempre foram conferidos pela lei ao administrador, mesmo no Estado Liberal. Caso contrário terse-ia um engessamento completo e indesejável da atividade administrativa, que se tornaria inoperante face ao dinamismo e variedade das situações concretas com que tem que lidar rotineiramente. No Estado Democrático de Direito, contudo, esses campos se expandiram e multiplicaram consideravelmente, assumindo a Administração Pública um papel decisivo na definição do interesse público concreto ${ }^{63}$.

Associado a esse fenômeno desenvolveu-se e agigantou-se a burocracia estatal, encarregada da implementação do interesse público. Com o alargamento das margens de definição do conteúdo de tal interesse, inclusive decorrente do emprego de conceitos abertos e indeterminados pela lei, somado à multiplicação das funções estatais, houve um esgarçamento do princípio da legalidade. Em paralelo, mostrou-se o Estado incapaz de desempenhar de forma satisfatória todas as funções que lhe foram conferidas, por limitações de diversas ordens, inclusive pela insuficiência de recursos materiais.

A preponderância da discricionariedade somada à incapacidade de consecução das finalidades públicas serviram de pretexto para a burocracia estatal unilateralmente escolher os interesses a serem perseguidos pelo Poder Público, no mais das vezes privilegiando aqueles atinentes à própria máquina estatal ou, ainda pior, dos indivíduos que ocupam os cargos públicos, negligenciando interesses de inquestionável relevância social ${ }^{64}$.

Se os administrados antes guardavam um elevado grau de tolerância com relação à ingerência nas suas esferas individuais pela Administração em virtude da atividade administrativa encontrar limitação na lei, que assim lhe dava legitimidade, nesse novo contexto, o esgarçamento do princípio da legalidade e a interpretação unilateral do

\footnotetext{
${ }^{63}$ "Sempre houve uma margem deixada pelo legislador para que o exercente do poder político delimitasse o que viria a constituir, concretamente, o interesse público em cada manifestação do poder político na seara administrativa. Porém, com o crescimento das áreas e formas de atuação do Estado essa margem amplia-se enormemente. Quanto mais amplas e mais complexas se tronam as manifestações do poder político, menos explícitos se mostram os limites legais para o exercício da função pública." MARQUES NETO, 2002, p. 92.

64 "No bojo desse processo de complexização ditado pela ampliação das funções do Estado, o aparato burocrático deixa de ser um mero instrumento da atuação do poder político dotado de uma racionalidade supostamente vinculada pelo Direito,

Transforma-se em um corpo autônomo, dotado muita vez de interesses próprios, escudado na unilateralidade e na excepcionalidade dos poderes inerentes à autoridade estatal. Deixa de ser agente do poder político para erigir-se como filtro político para exercício do poder. E o faz, muita vez, privilegiando seus interesses enquanto corpo social autônomo, ou mesmo refletindo interesses particularísticos desprovidos de legitimidade." (MARQUES NETO, 2002, p. 95).
} 
aparelho burocrático acerca do que venha a constituir o interesse público, somadas à ineficiência no atendimento das funções que lhe foram atribuídas constitucionalmente, geram um distanciamento entre as esferas do público e do privado e a uma crise de legitimidade do Estado ${ }^{65}$.

A partir de então, novos elementos passaram a ser considerados na definição do interesse público.

\subsection{FRAGMENTAÇÃO SOCIAL E O ESTADO PLURICLASSE}

O Estado Moderno se baseia numa visão de sociedade homogênea, monolítica, consistente, de forma a que dela possa extrair legitimidade enquanto centro decisório para definir o interesse geral a ser buscado. $\mathrm{O}$ espaço público configuraria o fórum adequado para a fusão e articulação dos interesses comuns dos indivíduos, em contraposição com a esfera privada, em que cada um busca seus interesses particulares próprios.

Entre essas esferas, entretanto, surgem núcleos de conglomeração de interesses ao redor dos quais os membros da sociedade, formal ou informalmente, se organizam e se associam. Esse fenômeno, apesar de assumir novas feições, não é recente, tendo Montesquieu chamado tais entes de corpos intermediários ${ }^{66}$. Rodolfo de Camargo Mancuso cita a família, os partidos políticos, os sindicatos e as associações como alguns desses agrupamentos, que comporiam uma forma de organização para a expressão de interesses coletivos $^{67}$.

\footnotetext{
65 "Este processo ocorre num momento em que o poder político e o aparelho administrativo típicos do Estado Moderno padecem de uma crise de legitimação, ditada em grande medida pelo crescimento do seu âmbito de atividade e pelo agigantamento de suas funções e crescente distanciamento do poder político em face dos seus destinatários." (MARQUES NETO, 2002, p. 99).

66 "E aqui se apresentam as entidades intermediárias, antigas figuras com roupagens novas; embora perdendo algumas de suas características históricas, herdadas da antiga teoria dos corpos intermediários, tal como a via Monstesquieu, hoje elas derivam sua justificativa de uma concepção pluralista da sociedade. Nem por outra razão já haviam sido identificadas por Alexis Tocqueville, em sua celebrada descrição da democracia nos Estados Unidos da América, como instituições fundamentais à sustentação do regime liberal e democrático. Isso explica por que só recentemente, com a expansão contemporânea dos interesses metaindividuais, esses entes intermediários voltaram a encontrar campo fértil para sua multiplicação nos países de vanguarda." (MOREIRA NETO, 2009, p. 613).

${ }^{67}$ MANCUSO, 2004, p. 63.
} 
Floriano Peixoto de Azevedo Marques Neto nota na atualidade a proliferação desses grupos de interesse levando ao parcelamento da sociedade homogênea a que chama de fragmentação social, designando diferentes formas de estratificação e fracionamento da esfera privada. A esse respeito, menciona três processos: (i) o neocorporativismo - que leva ao surgimento de agrupamentos originariamente amalgamados pela identidade profissional ou categoria econômica de seus membros; (ii) o pluralismo - despontando a criação, com maior espontaneidade, de agrupamentos informais que nascem em camadas marginalizadas da sociedade primeiramente como mecanismo de proteção contra agressões, e depois como grupos de reivindicação que se manifestam de forma desarticulada ou episódica; e (iii) o surgimento de movimentos sociais, que se agrupam em torno de questões específicas que afetam seus membros, adquirindo certa institucionalidade interna e estabilidade organizacional.

Esses corpos intermediários servem como veículo de reivindicação coletiva de interesses compartilhados por seus membros diante da incapacidade do Poder Público de ampará-los, por mais que, nos mais das vezes, encontrem correspondência em funções assumidas pelo Estado. Os indivíduos passam a ver nesses agrupamentos um local apropriado para a expressão dos seus interesses, sobretudo em razão do abismo experimentado no diálogo com o agente político, intérprete unilateral do interesse público, contra o qual o sujeito individualmente considerado pouco poderia fazer.

Diante da insuficiência estatal, casos há em que essas organizações passam a desempenhar funções concretas que caberiam ao Poder Público na defesa desses interesses coletivos, como, por exemplo, pela ação das chamadas organizações não governamentais (ONGs) ${ }^{68}$. Em paralelo, o Estado estabelece relações com empresas e outras entidades da sociedade civil valendo-se delas para indiretamente desenvolver atividades, incluindo obras e serviços públicos, atuando na esfera privada em decorrência de suas novas atribuições. Esses fenômenos revelam o surgimento e uma zona cinzenta entre as esferas pública e privada, que leva à crise da clássica dicotomia público-privado.

Nesse cenário de multiplicação dos interesses sociais, fica facilmente perceptível a inviabilidade do atendimento global das demandas a eles relacionados. Essa realidade leva

${ }^{68}$ MARQUES NETO, 2002, p. 122. 
ao "processo de fracionamento da ideia de universalidade ou de homogeneidade do interesse social", nas palavras de Floriano Peixoto de Azevedo Marques Neto ${ }^{69}$. A tarefa de construção ou identificação de fórmulas generalizantes do que constitua bem comum e vontade geral fica dificultada diante desse fracionamento. Se por um lado não se considera que tais interesses aglutinados sejam puramente individuais, por outro se reconhece ficarem afetos a grupos limitados que não se confundem com a totalidade da coletividade.

Como reação à crise de legitimidade, o Estado passa a paulatinamente adotar canais de diálogo com os grupos de interesse, apontando uma tendência em deixar o isolamento e a unilateralidade de suas decisões. A mudança de postura revela o enfraquecimento da visão do Estado como centro decisório absoluto e unívoco, concebendo-se uma nova Administração Pública, de disposição negocial, recebendo influências dos grupos sociais e servindo como constante mediadora dos conflitos de interesse resolvidos mediante $\operatorname{acordo}^{70}$.

\subsection{A DEFINIÇÃO DO INTERESSE PÚBLICO NA SOCIEDADE FRAGMENTADA}

Há quem entenda existir hodiernamente uma crise no conceito de interesse público. Floriano Peixoto de Azevedo Marques Neto aponta causas internas e externas que levam a essa crise. A interna, ou endógena, relaciona-se às dificuldades encontradas pelo Estado para interpretar e aplicar o interesse jurídico com base em conceitos indeterminados dispostos pela lei, frente à proliferação de funções assumidas a partir da implementação intervencionismo estatal. A externa, ou exógena, diz respeito aos processos de fragmentação social e de internacionalização da economia que abalam o papel do Estado

\footnotetext{
${ }^{69}$ MARQUES NETO, 2002, p. 122.

70 MARQUES NETO, 2002, pp. 123. "Já o processo de fragmentação social e política solapa o pode decisório, na medida em que tanto põe à prova a exclusividade da autoridade como leva também ao questionamento do próprio monismo jurídico.

O Estado passa a ter que conviver com outros núcleos de autoridade representados pelos diversos agrupamentos, transitórios ou não, de interesses. Tais agrupamentos passam a ter, crescentemente, autonomia em relação ao aparato estatal. Mais ainda, passa a ser indesviável a necessidade de interlocução, de mediação com estas instâncias sociais, as quais passam a substituir os partidos no processo de interlocução política, inclusive no tocante à produção legislativa." (MARQUES NETO, 2002, p. 128).
} 
de centro decisório unilateral e autoritário ${ }^{71}$. Propõe o autor uma nova forma de enfretamento da definição do interesse público:

Para tanto, parece-nos que a tendência será, dentro da perspectiva de um Estado Democrático de Direito, dotar a sociedade dos meios de participação plena no processo decisório e permitir que a aferição do interesse público possa ser fruto de um processo contínuo de cotejamento dos valores ou princípios que se embatem na situação concreta e no qual o Estado seja, a um só tempo, mediador de interesses sociais relevantes e colidentes mas também exerça um papel de implementador de interesses meta-individuais hipossuficientes no jogo social ${ }^{72}$.

Nessa visão, o interesse público, ao invés de singular e absoluto (homogeneidade do interesse público), apresentar-se-ia plural e multifacetado (heterogeneidade de interesse públicos). A sociedade fragmentada não se submete a construções de um bloco generalizante e homogêneo.

O Estado contemporâneo, na expressão cunhada por Massimo Severo Giannini e disseminada entre a doutrina de direito público atual, caracteriza-se como "Estado pluriclasse", sofrendo a influência da diversidade de grupos resultantes do processo de fragmentação social, com o seu dinâmico rearranjo em conformidade com os interesses que se tornem relevantes em cada caso, estabelecendo posições jurídicas contrapostas. Esse fenômeno tem origem na adoção do sufrágio universal e extensão para todos os cidadãos do direito de participar do processo eleitoral, inviabilizando o reconhecimento de uma única classe dominante. Marçal Justen Filho descreve essa nova realidade:

\footnotetext{
${ }^{71} \mathrm{O}$ autor elenca quatro ordens de fatores subjacentes a essa crise exógena: (i) em razão da fragmentação social, haveria uma pluralidade de unidades orgânicas e não uma um todo homogêneo coletivo; (ii) a dicotomia público/privado não comportaria as fontes supranacionais de normatividade, decisão e conflito; (iii) a ampliação do espaço de confusão entre o público e o privado seja por organizações da sociedade civil assumirem o desempenho de funções estatais, seja pelas intervenções da Administração Pública no mercado valendo-se de relações de Direito Privado; e (iv) os interesses da coletividade submetidos ao poder político não compreendem todos aqueles que demandam tutela estatal, restando inservível a noção de interesse público por ser excessivamente genérica (MARQUES NETO, 2002, pp. 146/147).

${ }^{72}$ MARQUES NETO, 2002, p. 147.
} 
O exercício do poder político retrata a pluralidade de interesses sociais e a segmentação dos diferentes grupos. Existem agrupamentos com interesses comuns, dentro de limites estreitos e com extensão temporal precária. Cada classe comporta interesses contrapostos. A democracia contemporânea externa-se numa espécie de interminável reorganização de interesses individuais e coletivos. As composições entre os diferentes grupos de interesses assemelha-se a um processo caleidoscópico, em que cada arranjo é distinto do existente em momentos anteriores e posteriores.

Isso tudo conduz à impossibilidade de aludir à maioria senão como força de expressão, indicando composições temporárias e limitadas entre os diferentes segmentos da sociedade ${ }^{73}$.

No Estado pluriclasse preponderam as situações em que não há um interesse público único e homogêneo, mas sim plúrimo e heterogêneo ${ }^{74}$. A esse respeito, Maria Sylvia Zanella di Pietro aponta adotar-se no Brasil, com base no preâmbulo da Constituição de 1988, o conceito de sociedade pluralista, fundada pela diversidade de seus membros nas mais diferentes searas, estabelecendo-se tensões múltiplas de forma rotineira. Nesse contexto, o interesse público deixa se ser visto somente como o interesse comum de todos, eis que este se torna raro, abrangendo outros atinentes a coletividades menores ${ }^{75}$.

A tendência aponta a mudança no papel da Administração no que toca à definição dos interesses por ela tutelados. Ao invés de mera intérprete autoritária do interesse público, incorpora a função de mediadora de interesses públicos. Contudo não fica restrita a manejar os interesses que lhe são submetidos pelos corpos intermediários, eis que estes não assumem a defesa de todos aqueles socialmente relevantes. Considera-se, nesse tocante, a existência de duas ordens desses interesses transindividuais. Além daqueles em torno dos quais os agrupamentos sociais ordinariamente se reúnem, há outros que restam subrepresentados. Norbert Reich, conforme exposição de Floriano Peixoto de Azevedo

${ }_{73}^{73}$ JUSTEN FILHO, 1999, p. 121.

74 "No 'Estado pluriclasse' (Giannini), a identificação do interesse público não é uma tarefa fácil, nem tampouco pacífica. A realidade mostra que os interesses da esfera pública são heterogêneos. Portanto, não se pode mesmo falar do abstrato e genérico interesse público e coletivo, senão interesses." (DERANI, 2002, p. 50). Na mesma linha, MOREIRA NETO, 2009, p. 14.

${ }^{75}$ DI PIETRO, 2007, pp. 223/224. 
Marques Neto, chama os primeiros de interesses especiais e os segundos de interesses difusos. Enquanto os interesses especiais são apropriados por agentes sociais em virtude de corresponderem a benefícios identificáveis atinentes a certas comunidades determináveis, os difusos representam um bem público e que, portanto, se referem à qualidade de vida global $^{76}$. A esse respeito, acrescenta Floriano Peixoto de Azevedo Marques Neto:

\begin{abstract}
Estas duas ordens de interesses seriam transindividuais. No entanto, os interesses especiais seriam, em regra, devidamente sustentados e aglutinados em sede de grupos de interesse. Já os interesses difusos, em que pese a muitas vezes serem encampados por movimentos sociais, podem apenas em alguma medida ser organizados em grupos de pressão ${ }^{77}$.
\end{abstract}

Ambas as classes de interesses são passíveis de consideração pela Administração Pública, por mais que entre elas seja comum estabelecerem-se relações de conflito, disputando a alocação de bens, direitos e oportunidades. Diante de sua hipossuficiência, todavia, devem os interesses difusos ser foco de especial atenção do Poder Público. Por isso é que cabe ao Estado assumir o papel de mediador ativo de interesses, prezando pela afirmação e efetivação dos interesses difusos, sem desprezar os interesses especiais e respeitando os direitos individuais. O sopesamento dos interesses e a eleição daqueles a serem perseguidos há de depender de uma avaliação conjuntural de acordo com critérios de relevância.

A definição do que representa o interesse público recebe outras formulações na linha da composição de interesses. Evocando a doutrina de Georges Vedel e Pierre Devolvé, Rodolfo de Camargo Mancuso defende que o conceito de interesse público se estabelece em dois planos: político e jurídico. No campo político, corresponde a uma arbitragem de interesses privados, observando, por um lado, que não se trata da mera somatória de tais interesses, eis que nem sempre compatíveis entre si, e, por outro, que deles também não

\footnotetext{
${ }^{76}$ MARQUES NETO, 2002, p. 159. O autor brasileiro aponta, contudo, que esses interesses difusos não correspondem ao conceito construído pelos processualistas, pois aqui o que é relevante não é a amplitude e transcendência do interesse, mas sim a inexistência de um ator social que seja capaz de dotar-lhes de suficiente especialidade (MARQUES NETO, 2002, p. 162). Razões há para se discordar dessa posição, pois se não forem idênticos, são muitos similares os interesses a que apontam os conceitos, eis que os interesses difusos, diante da indeterminabilidade de seus titulares, geralmente não apresentam tantos incentivos quanto outros interesses transindividuais para que sua defesa concreta seja assumida por atores sociais.

${ }^{77}$ MARQUES NETO, 2002, p. 160.
} 
está dissociado, uma vez devem ser os próprios homens os beneficiários finais do interesse público. Para se realizar tal arbitramento levam-se em conta critérios quantitativos, buscando a predominância dos interesses afetos a um contingente maior de pessoas, bem como qualitativos, dando prevalência para interesses tidos por mais valorosos, a despeito do número dos sujeitos a que estão afetos. No plano jurídico, a questão que se coloca é a determinação da competência para o exercício dessa arbitragem ${ }^{78}$.

Nessa linha, Marçal Justen Filho afirma não caber determinar o interesse público pelo critério da maioria. No Estado Democrático, não é sempre o interesse da maioria que deve prevalecer, com a aplicação de critérios quantitativos. Também interesses das minorias cumprem ser reconhecidos como interesse público, por critérios qualitativos, de acordo com parâmetros fixados na Constituição ${ }^{79}$. Outrossim, o autor posiciona-se de forma contrária à sua identificação com o interesse da sociedade, desvinculado de interesses individuais concretos, na medida em que cria margem para o autoritarismo, por não exigir do Estado a correlação entre o interesse por ele perseguido e as situações concretas que tocam aos membros da sociedade, concedendo-se ao agente público poder para definir o conteúdo desse interesse social sem substrato nas realidades individuais enfrentadas ${ }^{80}$. O interesse público, de outro modo, tem ambos os componentes, correspondendo ao mesmo tempo a um interesse da sociedade e a interesses concretos de parcelas da população ${ }^{81}$.

No cenário de emergência de interesses disseminados na sociedade dotados de relevância social, amparados em valores constitucionais, e que disputam a alocação de bens e recursos

\footnotetext{
${ }^{78}$ A primeira fonte é a Constituição, que além de fixar desde logo as grandes finalidades de interesse público a serem atingidas pelo Estado, estabelece as competências para a determinação concreta do interesse público $^{78}$. Tradicionalmente, cabe ao legislador, constituinte e ordinário, o arbitramento do interesse público, acompanhado da indicação das regras e meios para a consecução dos correspondentes fins. Dentro dos parâmetros legais e constitucionais, no exercício da competência que lhe é atribuída, também cabe à Administração Pública a definição do interesse público, sobretudo por meio dos de um juízo de oportunidade e conveniência exercido na sua atuação discricionária, ou nos atos políticos. (MANCUSO, 2004, pp. 33/34). Tradicionalmente não se considera atribuição do Poder Judiciário definir o conteúdo do interesse público no exercício da função jurisdicional, sobretudo em se considerando a tripartição dos Poderes. Modernamente, contudo, admitindo-se o alargamento das atividades do juiz, sobretudo em sede de fixação de políticas públicas, há quem reconheça a possibilidade do juiz exercer mais do que o mero controle estrito de legalidade do ato administrativo, proferindo decisões em que determina condutas ao Estado-administração para o atendimento de direitos sociais, dessa forma fixando o interesse público.

79 JUSTEN FILHO, 1999, p. 122. Ademais, no contexto do Estado contemporâneo, pluriclasse, não se estabeleceria uma maioria perene e estruturada que pudesse vir a ser mensurada, ou um conjunto de interesses homogêneos o suficiente para que pudesse assumir a condição de interesse da maioria. Os interesses contrapostos se arranjam e rearranjam de forma dinâmica em diversos grupos de interesse, criando um ambiente sem condições para que se pronuncie uma verdadeira maioria.

${ }^{80}$ JUSTEN FILHO, 1999, p. 122.

${ }^{81}$ JUSTEN FILHO, 1999, p. 124.
} 
do Estado, em consideração aos quais se formula um entendimento de interesse público aberto e maleável, sustenta-se uma noção de interesse público sob a perspectiva exclusivamente processual. Uma vez inviável ou mesmo impossível a formação de um consenso a respeito dos fins a serem alcançados em cada caso concreto, a aceitação social pode ser ao menos exigida quanto ao processo decisório a ser adotado para a determinação do interesse público na situação que se apresenta. Consenso com relação aos meios, quanto ao processo decisório, mas não com relação à decisão em si $^{82}$. O processo torna-se, assim, o elemento legitimador do interesse escolhido. As técnicas adotadas para a obtenção da decisão devem levar em conta aquilo tido por relevante pela sociedade para a divisão justa dos recursos sociais, que seja eficaz para a satisfação das necessidades coletivas e afastando a possibilidade de decisões incoerentes. Mais legítimo se tornará o processo se admitida a participação dos grupos representativos dos interesses envolvidos.

Isso não quer dizer, entretanto, que a decisão resultante do processo será necessariamente boa ou que o processo funcionará sem influências indevidas. Mesmo seguindo à risca o devido processo legal, é possível que se faça uma escolha nefasta, moralmente inaceitável. Por isso torna-se necessário o temperamento da concepção puramente processual com o estabelecimento de critérios substanciais para a definição, tendo por base os "parâmetros mínimos pelos quais a convivência social é possível em um regime de liberdade, permitindo conciliar interesses particulares, de indivíduos e grupos, com aqueles pertencentes a toda a coletividade" ${ }^{83}$. Não sendo possível a definição apriorística de critérios fechados e exaustivos, defende Carlos Alberto Salles a adoção de um princípio de justiça distributiva a ser empregado nas decisões de definição do interesse público prevalecente e da alocação de recursos sociais. Nesse passo, no que toca a interesses referentes a bens comuns ou coletivos, as decisões seriam orientadas de forma a dar a tais bens uso que não impeça seu uso por outros, ou seja, de forma não excludente, mantendose o seu caráter de bens coletivos. Tratando do meio ambiente, por exemplo, qualifica o dano ambiental como uma forma de apropriação individual de um bem coletivo, de forma a privar os demais de gozarem do meio ambiente ecologicamente equilibrado, bem comum do povo.

\footnotetext{
82 "Supondo, portanto, a existência de um consenso quanto aos meios, isto é, ao processo de decisão, é possível definir o interesse público apenas na maneira processual de sua conceituação." (SALLES, 2000, p. 55).

${ }^{83}$ SALLES, 2000, p. 57.
} 
Susana Henriques da Costa caracteriza como conteúdo substancial mínimo do conceito de interesse público a ideia de justiça, que se confundiria com o bem comum.

Os valores fundamentais vigentes em uma determinada sociedade correspondem à sua ideia de justiça, dentro de um certo contexto histórico. Ao buscar a concretização desses valores, o Estado estará buscando o bem comum e, por meio deste, o interesse público ${ }^{84}$.

Segundo Marçal Justen Filho, o interesse público deve ser pensado tendo por ponto de partida a dignidade da pessoa humana, que caracteriza o princípio fundamental do qual decorre todo sistema, e que deve orientar toda atuação estatal. Todos os demais princípios e regras tem caráter instrumental, voltados para a realização daquele princípio. O homem deve ocupar posição central para o Direito e para o Estado, não podendo se admitir servir como instrumento para o atendimento de outros fins. $\mathrm{O}$ autor prega a personalização do Direito Administrativo, afastando a aplicação do princípio da supremacia do interesse público na medida em que sirva de motivação para a agressão ao valor da dignidade da pessoa humana. O que prevalece, de outro modo, é o princípio da supremacia da dignidade da pessoa humana. Sustenta que não se trata de visão individualista, pois não se estaria a defender a dignidade de um único sujeito, mas de todos que compõem a sociedade.

Diante de todas essas considerações, resta claro que há um processo de transformação no que, em termos práticos, identifica-se por interesse público. No que toca ao seu referencial, não o se considera como um interesse coletivo destacado do interesse dos particulares, devendo neste encontrar substrato. Quanto ao seu aspecto de extensão, não se exige que no caso concreto se compatibilize com interesses pessoais da integralidade da sociedade, ou mesmo de uma maioria estabelecida, mesmo porque, muitas vezes uma maioria sequer pode ser identificada, diante da fragmentação da sociedade externada pela pluralidade de interesses contrapostos, alguns dos quais representados por grupos de interesses e outros sub-representados, ditos interesse difusos. Esses grupos de interesse passam a exercer um papel relevante na definição do interesse público, influenciando os processos decisórios tanto do legislativo, na produção de leis e de políticas públicas, quanto do executivo, no tocante à implementação das políticas públicas, políticas de governo e mesmo atividades

\footnotetext{
${ }^{84}$ COSTA, 2009, pp. 58/59.
} 
administrativas isoladas. Nesse contexto em que reina o dissenso, os mecanismos decisórios adotados para a determinação das medidas de interesse público assumem especial importância, tornando-se o processo o elemento legitimador da decisão produzida. Por mais, todavia, que se reconheça legitimidade a interesses de parcelas variáveis do todo social, vindo a ser considerados no processo de apuração do interesse público, não se deve olvidar os valores e princípios fundamentais do sistema, consagrados na Constituição, como os ideais de justiça e vedação à apropriação exclusiva de bens coletivos, todos tendo por diretriz última a dignidade da pessoa humana. Por consequência, o interesse público pode ser identificado em medidas que beneficiem um único indivíduo ou mesmo indivíduos dispersos, que não tenham se organizado em um grupo de interesse, cabendo ao Estado zelar por sua proteção especialmente em vista de sua subrepresentatividade. Por mais que em dadas circunstâncias concretas a proteção a interesses individuais, pertences a minorias ou mesmo de extensão dispersa e titularidade indeterminada pareçam não encontrar suporte ou mesmo contrariar à vontade imediata de grande parte da população, pode representar medida de interesse público por encontrar amparo em valores e princípios de maior grandeza que permeiam e amalgamam a sociedade, constituindo bem comum ${ }^{85}$.

\subsection{CONFLITOS ENVOLVENDO O INTERESSE PÚBLICO}

Não é apenas por tornar sua consecução uma finalidade pública que a qualificação de um interesse como interesse público o coloca em uma posição de vantagem. Em virtude da circunstância dos interesses rotineiramente encontrarem-se em interação, bem assim em

\footnotetext{
${ }^{85}$ A sociedade contemporânea consumista apoia-se na exarcebação das necessidades, que são, conforme visto, individuais por natureza. Diante da acumulação sem precedentes de necessidades, os conflitos intrassubjetivos se intensificam na mesma toada. Além daquelas necessidades que lhe sejam mais essenciais, incentiva-se o indivíduo a privilegiar a satisfação das materiais, e que lhe proporcionem benefícios pessoais maiores e mais imediatos. O altruísmo, o senso de coletividade e as necessidades morais não são alimentados, a não ser em ocasiões esporádicas e pontuais, de forma a se enfraquecer a noção de comunidade. $\mathrm{O}$ futuro e o coletivo são preteridos com relação ao presente e individual. Daí porque não raro o sujeito adquira roupas sabidamente fabricadas com utilização de mão-de-obra em condições análogas à escravidão, consuma alimentos produzidos ou extraídos com o uso de métodos sabidamente causadores de relevante impacto ambiental, como, por exemplo, o palmito juçara extraído de palmeiras da Mata Atlântica com o corte do vegetal, seja contrário ao recolhimento de tributos ou mesmo adote uma dieta insalubre que o leve à obesidade e aos riscos a ela atinentes. Mesmo que àqueles valores e interesses relativos ao próximo e à coletividade não contrastem necessariamente com seus interesses pessoais mais próximos, a tendência é a de que o indivíduo não se empenhe na perseguição daqueles, preferindo concentrar seus esforços e recursos na satisfação destes. Essas é uma das causas para que, no geral, grande parte do contingente populacional não demonstre apoio a interesses relevantes a grupos menores ou a indivíduos isolados, demonstrando apatia ou contrariedade por não se privilegiar outros interesses que lhe são mais próximos. Por mais que não seja medida de popularidade, a proteção aos interesses desses grupos ou indivíduos pode significar medida de interesse público em razão dos valores e princípios em que se fundam.
} 
razão da escassez dos bens que constituem seu objeto, não raro se estabelecem conflitos. Termos gerais, em caso de conflito entre interesse público e interesse privado, o primeiro prevalece por aplicação do princípio da supremacia do interesse público.

Segundo Celso Antonio Bandeira de Mello, trata-se de princípio geral de Direito, aplicável não apenas na seara do Direito Administrativo, constituindo pressuposto básico do convívio social, inerente a todas as sociedades. Apesar de imanente em diversos dispositivos constitucionais, não se encontra explicitamente previsto como princípio na Constituição de 1988. Sua decorrência em outros ramos do direito incluiria a defesa do consumidor e do meio ambiente, bem como a função social da propriedade.

Se com o Estado Liberal a tônica era a proteção das liberdades individuais, de forma a se fazer necessário o princípio da supremacia do interesse público para permitir ao Poder Público atuar nos campos mais limitados que formavam suas atribuições, para Maria Sylvia Zanella Di Pietro, com o Estado Social de Direito, fortalece-se o princípio, eis que o Estado é demandado a intervir na esfera privada de forma a promover interesses sociais, entrando em conflitos mais numerosos com interesses individuais, e fazendo prevalecer o interesse geral perseguido, seja por meio do poder de polícia ou pela prestação de serviços públicos $^{86}$.

Assim é que, conforme já se aludiu neste capítulo, o regime de jurídico-administrativo tradicionalmente tem como um de seus essenciais princípios o da supremacia do interesse público sobre o particular. O estabelecimento e a relevância desse princípio, na sua concepção tradicional, traz em si conotações de duas ordens.

Indica ser em cada situação concreta o interesse público "absoluto, uno, indivisível e exclusivo" ${ }^{87}$, de forma a que ele prevaleça sobre a multiplicidade dos interesses $\operatorname{privados}^{88}$. De fato, permeia a doutrina clássica o entendimento de que o interesse público

\footnotetext{
${ }^{86}$ DI PIETRO, 2007, p. 92.

${ }^{87}$ MARQUES NETO, 2002, p. 86.

${ }^{88}$ MARQUES NETO, 2002, p. 81.
} 
é um único interesse, o que significa dizer que se um interesse for identificado como interesse público, nenhum outro poderá $\operatorname{ser}^{89}$.

Ademais, o princípio apresenta o interesse público em contraposição aos interesses privados, de forma que sobre estes deva prevalecer. No tocante a esse segundo aspecto, pressupõe uma conflituosidade imanente entre o interesse público e os interesses privados, o que, conforme preleciona Floriano Peixoto de Azevedo Marques Neto, tem explicação histórica. O conceito de interesse público foi construído em oposição ao individualismo reinante no Estado Liberal, que tinha por paradigma o prevalecimento dos interesses individuais privados. Nesse contexto é que foi o Poder Público conclamado a regular e limitar a atividade privada, submetendo-a ao bem comum. A afirmação do interesse público, assim, representaria a negação dos interesses privados, egoísticos, efetivando-se somente mediante o sacrifício ou restrição a estes ${ }^{90}$.

Ambas as implicações do princípio da supremacia do interesse público encontram críticas doutrinárias. Conforme visto, a noção de um interesse público único e homogêneo tornouse alvo de críticas com o desenvolvimento do Estado Democrático de Direito, a multiplicação das funções estatais, a fragmentação social e a ascensão dos grupos de interesse.

Ademais, a completa dissociação entre interesse público e interesse particular não se sustenta, retomando-se as considerações a respeito dos interesses individuais formarem o substrato do interesse público. Celso Antônio Bandeira de Mello defende existir um "falso antagonismo entre o interesse das partes e o interesse do todo". O interesse público não seria algo dotado de consistência autônoma, ou seja, desvinculado dos interesses das partes que compõem o todo. A esse respeito, argumenta não ser possível cogitar um interesse público contrário ao interesse de cada um dos membros da sociedade. Na sua concepção, o interesse público nada mais seria do que "o interesse resultante do conjunto dos interesses

\footnotetext{
${ }^{89}$ Essa sua dimensão globalizante distinguiria o interesse público de outros interesses metaindividuais, como os interesses difusos e coletivos, aos quais se admite entrarem em conflito com outros interesses difusos e coletivos. (MARQUES NETO, 2002, p. 86).

${ }^{90}$ MARQUES NETO, 2002, p. 82.
} 
que os indivíduos pessoalmente têm quando considerados em sua qualidade de membros da Sociedade e pelo simples fato de o serem" ${ }^{91}$.

A distinção entre as dimensões pública e privada dos interesses individuais por ele propugnada é a mesma da de Alf Ross. Enquanto um sujeito não tem interesse em ter uma sua propriedade desapropriada, para ele interessa a existência do instituto da desapropriação, pois ele se faz de instrumento para a construção de bens públicos que lhe trazem benefícios.

Por fragilizarem-se as duas assunções em que se baseia o princípio da supremacia do interesse público, passa o mesmo a ser, ao menos na sua concepção tradicional, criticado, havendo mesmo quem entenda não mais se sustentar, sendo substituído por outros princípios ou critérios de resolução de conflitos ${ }^{92}$.

Propugna-se seja o interesse público visto como "um elo de mediação de interesses privados dotados de legitimidade" 93 . Daí porque questionar-se a aplicação desmedida do princípio da supremacia do interesse público sobre o privado. A titularidade de um interesse por um particular não pode ser vista como automaticamente contrário às finalidades públicas. Em certa medida, reconhece-se que em algumas searas o atendimento do interesse dos particulares significa o atendimento do interesse público ${ }^{94}$. Isso fica mais evidente se tais interesses privados forem dotados de faceta metaindividual.

Nas situações concretas em que interesses de tal espécie colidem, como, por exemplo, na disputa do uso de terras para fins residenciais de população carente ou para a preservação ambiental, há fundamento para se sustentar que ambos correspondem a interesse público

91 BANDEIRA DE MELlO, Celso Antônio. Curso de Direito Administrativo. 28. ed., São Paulo: Malheiros, 2011, p. 61.

${ }^{92}$ Dentre os que negam a concepção tradicional do princípio da supremacia do interesse público, Diogo de Figueiredo Moreira Neto sugere sua substituição pelo princípio da supremacia dos princípios fundamentais (MOREIRA NETO, 2009, p. 99); Odete Medauar indica assumir a feição de princípio da preponderância do interesse público sobre o interesse particular (MEDAUAR, Odete. Direito Administrativo Moderno: de acordo com a EC 19/98. 4. ed., rev., atual. e ampl. São Paulo: Revista dos Tribunais, 2000, p. 153); Marçal Justen Filho prega se submeter ao princípio da supremacia da dignidade da pessoa humana (JUSTEN FILHO, 1999, p. 125) e Floriano Peixoto de Azevedo Marques Neto alude à sua substituição pelo princípio da prevalência dos interesses públicos (MARQUES NETO, 2002, p. 165).

93 MARQUES NETO, 2002, p. 149.

${ }^{94}$ MARQUES NETO, 2002, p. 152. 
primário, não sendo aceitável uma solução que privilegie um por autoritariamente considerá-lo interesse público único, de forma a desconsiderar o outro por completo.

A supremacia daria lugar à prevalência dos interesses públicos, significando, por um lado, a não perseguição de interesses particularíssimos, desprovidos de amplitude transindividual, e por outro, a necessidade de ponderação de todos os interesses coletivos envolvidos na situação concreta, bem assim a necessidade de exteriorização das razões para o prevalecimento de um em detrimento dos demais ${ }^{95}$.

Nessa realidade, também se exigiria um redimensionamento do princípio da indisponibilidade do interesse público. Ao se admitir a existência de uma pluralidade de interesses públicos heterogêneos, de rigor se considerar que entre eles possa se estabelecer um conflito em diferentes situações concretas. Por mais que deva o Estado buscar uma solução que privilegie ambos os interesses conflituosos, não raro será inviável o seu atendimento integral simultâneo, exigindo-se para o seu acomodamento certo grau de redução de objeto, sem importar no seu sacrifício total. Um dos exemplos em que se evidencia de forma mais cristalina essa questão diz respeito ao meio ambiente. No ordenamento jurídico vigente constitui medida de interesse público a preservação do meio ambiente ecologicamente equilibrado, isento de danos ambientais. Ocorre que a ação humana gera por natureza degradação ambiental. Logo, em certa medida, necessário se faz permitir o desenvolvimento de atividades que causem impacto no meio ambiente, por mais que se exija a adoção de medidas mitigantes e compensatórias do dano causado, a existência de meios alternativos com a redução do impacto, bem assim o cotejamento entre os benefícios e malefícios proporcionados pela atividade. Diante da necessidade de equacionamento dos conflitos de interesses envolvendo o interesse público, perde a indisponibilidade o seu caráter absoluto ${ }^{96}$. Vale destacar, contudo, que um interesse

\footnotetext{
${ }^{95}$ De acordo com Diogo de Figueiredo Moreira Neto, "se existe este dever de ponderação, tem-se aqui muito mais do que um método ou de um resultado de sua aplicação, mas de um autêntico princípio jurídico, tão importante quanto qualquer outro de natureza instrumental, pois sua função é a de concorrer tanto para conduzir o legislador à formulação do melhor preceito em abstrato, quanto para orientar o aplicador para atingir a mais perfeita observância da ordem jurídica no caso concreto.

O objeto da ponderação está mais no nível dos processos interpretativos, onde se situam os valores, os interesses, os bens, as liberdades e, coroando-os, os direitos fundamentais (...)" (MOREIRA NETO, 2009, 0. 94).

96 "A flexibilização desse conceito apresentará grande relevância no Direito contemporâneo, pois em diversas circunstâncias será necessário ponderar interesses públicos definidos em lei, cotejando-os com outros, igualmente protegidos, mas que lhe sejam concorrentes, visando a uma mais justa e melhor realização do Direito.
} 
público somente pode ceder se e na medida em que conflite com outro interesse de envergadura constitucional igual ou superior, como o que represente direito fundamental ${ }^{97}$.

Outro problema atinente à aplicação do princípio da supremacia reside na natureza do interesse público de conceito jurídico indeterminado. Admitindo-se ao agente público a competência de qualificar um interesse como público sem parâmetros precisos a orientar tal tarefa implicaria o risco de que interesses de outro jaez viessem a ser perseguidos como se dotados de natureza pública ${ }^{98}$. O agente abrigaria-se, assim, no princípio da supremacia para fazer prevalecer interesse cujo caráter seria questionável. Uma vez que impere incerteza a respeito da natureza do interesse, menos absoluto deve ser o princípio da supremacia, abrindo-se a oportunidade para se questionar em cada caso qual interesse deverá preceder o outro. O problema apontado por Marçal Justen Filho refere-se à indeterminação do conceito, que elava o exercente do poder a abrigar-se no princípio da supremacia afirmando que o que está a privilegiar é o interesse público.

Maria Sylvia Zanella de Pietro afirma que as críticas ao princípio da supremacia do interesse público são infundadas e camuflam o propósito de privilegiar interesses econômicos em detrimento de outros também protegidos pelo ordenamento, sob influência de uma doutrina neoliberal ${ }^{99}$. Argumenta que tal visão contrapõe-se às tendências observadas inclusive com relação ao direito privado, que sofre crescente influência do direito público, colocando o social à frente do individual. Cita, como exemplos, as ideias de função social do contrato e função social da propriedade, representando a propriedade privada e a liberdade contratual representam baluartes do liberalismo. Em linha com essas tendências, também o direito de ação, tradicionalmente exercido para a proteção de

São modernos exemplos da aplicação da flexibilização na satisfação de interesses que eram antes considerados como absolutamente indisponíveis, os variados tipos de acordos substitutivos, um instituto que vem sendo adotado na legislação brasileira para harmonizar a satisfação de interesses públicos com interesses individuais, coletivos ou difusos valorizados pelo Direito, dos quais são já costumeiros exemplos os termos de ajustamento de conduta (TACs), os termos de compromisso e assemelhados." MOREIRA NETO, 2009, p. 99.

${ }^{97}$ Um dos critérios cuja aplicação se defende no que toca à reformatação do princípio da indisponibilidade do interesse público diz respeito ao privilegiamento dos interesses difusos, de forma a que não possam ser preteridos pelo Poder Público pela sua hipossuficiência social (MARQUES NETO, 2002, p. 165).

98 JUSTEN FILHO, 1999, p. 116.

99 "A doutrina que se considera inovadora compõe, sob certo aspecto, uma ala retrógrada, porque prega a volta de princípios próprios do liberalismo, quando se protegia apenas uma classe social e inexistia preocupação com o bem comum, com o interesse público. Ela representa a volta aos ideais de fins do século XVIII. As consequências funestas do liberalismo recomendam cautela na adoção dessas ideias, até porque se opõem aos ideais maiores que constam do preâmbulo e do título inicial da Constituição, para valorizarem excessivamente determinados princípios da ordem econômica, privilegiando a liberdade de iniciativa e de competição." (DI PIETRO, 2007, p. 101). 
interesses individuais ${ }^{100}$, torna-se instrumento de proteção do interesse público, por intermédio das ações coletivas.

Nega também que a indeterminabilidade conceitual do interesse público constitua empecilho para a sua aplicação. A adoção de conceitos indeterminados é técnica adotada em diversos ramos do direito, e nem por isso causa a inoperância do ordenamento. Como conceitos jurídicos, "são passíveis de interpretação", existido hoje toda uma doutrina justamente voltada a fornecer instrumentos para a concretização de conceitos jurídicos indeterminados, inclusive ampliando a possibilidade de controle judicial ${ }^{101}$. Daí a importância da definição do conteúdo do interesse público coforme as considerações expostas no item anterior.

Nota, ademais, que nenhum dos princípios de direito administrativo goza de caráter absoluto e aplicação irrestrita. O próprio ordenamento prevê medidas de proteção a interesses particulares, como, por exemplo, o dever de prévia e justa indenização no caso de desapropriação. Assim é que a consagração do princípio da supremacia não importa a sua aplicação desmedida. Serve como critério para a resolução de conflitos na forma em que dispuser o ordenamento. Por isso não haveria incompatibilidade entre o princípio da supremacia e a proteção às liberdades individuais e outros direitos fundamentais, os quais são resguardados por normas presentes no ordenamento, no mais das vezes de caráter constitucional $^{102}$. Sob outra perspectiva, a proteção a interesses individuais, privados, constitui interesse público na medida em que estiver prevista na Constituição ${ }^{103}$.

\footnotetext{
${ }^{100}$ Apesar de considerar-se o direito de ação de natureza pública, exercido em face do Estado.

${ }^{101}$ DI PIETRO, 2007, pp. 97/98.

102 Para Diogo de Figueiredo Moreira Neto, de outro modo, em um sistema em que se protegem direitos fundamentais, não cabe reconhecer o princípio da soberania do interesse público. Nas palavras do autor: "No constitucionalismo pós-moderno, que gravita em torno dos direitos fundamentais, não há como sustentar-se o antigo princípio da supremacia do interesse público, que partia da existência de uma hierarquia automática entre as categorias de interesses públicos e privados. Na verdade, tal relação constante não mais de suporta, porque no Estado Democrático de Direito, quaisquer interesses só podem estar subordinados ou supraordinados, uns aos outros, conforme disponha a lei, mas esta, por sua vez, não poderá romper a hierarquia axiológica constitucional estabelecida em função do primado da pessoa humana, que se expressa nas liberdades, direitos e garantias fundamentais, e que poderá ser apenas e excepcionalmente temperado pela previsão de um específico interesse público que justifique limitar ou condicionar essas expressões indissociáveis das pessoas.

Assim, tanto a definição do interesse público quanto a imposição de uma específica supremacia, preterindo quaisquer outros interesses igualmente agasalhados pela ordem jurídica dependerão, única e exclusivamente, das opções que sejam feitas, expressamente na Constituição e, só então, mas sempre desta dependente, inafastavelmente previstas nas leis." (MOREIRA NETO, 2009, p. 95).

103 "De outro lado, é evidente, e de evidência solar, que a proteção do interesse privado nos termos do que estiver disposto na Constituição, é, também ela, um interesse público, tal como qualquer outro, a ser fielmente resguardado." BANDEIRA DE MELLO, 2011, p. 69.
} 
O argumento da existência de uma pluralidade de interesses públicos também não sustenta a derrocada do princípio da supremacia do interesse público. Dele decorre a precedência do público com relação ao privado. Se todos os interesses contrapostos constituírem interesse público, a solução para o impasse não será ditada pelo princípio da supremacia. A sua inaplicabilidade nesse caso não significa, contudo, que deixe o princípio de existir ${ }^{104}$.

Claro que, se essas situações não significam o perecimento do princípio, revelam a perda, ao menos parcial, de sua utilidade como critério de resolução de conflitos, especialmente em se tratando daqueles travados entre interesses públicos. A questão aqui é que o equacionamento desses conflitos em alguma medida importará a negação ou tolhimento de um interesse. Sob o pressuposto de que o interesse público encontra esteio em interesses individuais ou tem manifestação nas esferas pessoais, a preterição de um interesse público impactará negativamente interesses que tocam a pessoas. $\mathrm{O}$ indivíduo desse modo prejudicado ou não favorecido que venha a reclamar a proteção do seu interesse teria o seu pleito negado sob o fundamento de que não poderia prevalecer pela aplicação do princípio da supremacia do interesse público. Ocorre que, nesse caso, o interesse preterido também seria público, inviabilizando a aplicação do princípio.

Tratando-se de conflitos entre interesses públicos, Lúcia Valle Figueiredo, adotando uma concepção positivista do interesse público, indica que a determinação do prevalecente deve decorrer do próprio sistema jurídico, por intermédio da interpretação sistemática amparada na principiologia ${ }^{105}$ que permeia o sistema.

Nos casos de conflitos entre interesses contrapostos que digam respeito a princípios e valores fundamentais, Marçal Justen Filho propugna pela aplicação da proporcionalidade, demandando a ponderação dos interesses e a sua homogeneização, por meio da introdução

\footnotetext{
104 "É difícil ocorrer que todos os indivíduos tenham interesse comum, cuja soma corresponda a um interesse público único. Talvez por isso Hector Escola fale em 'maioria dos indivíduos'. Pode nem ser a maioria dos indivíduos. Pode haver interesses públicos conflitantes, como ocorre com a construção de rodovias e de usinas nucleares, cujo interessem, em regra, conflita com o interesse na proteção do meio ambiente. Nesse caso, cabe à Administração Pública e, em última instância, ao Judiciário decidir qual o interesse proteger.

O importante é que existem interesses públicos que merecem a proteção do Estado, ainda que em detrimento de interesses individuais. É do ordenamento jurídico que se extrai a ideia de interesse público e quais os interesses públicos a proteger. Interesses públicos, correspondentes ou não à soma de interesses individuais, sempre existiram e sempre vão existir, a menos que se queira negar o papel do Estado como garantidor do bem comum." (DI PIETRO, 2007, p. 99)

${ }^{105}$ FIGUEIREDO, 2008, p. 37.
} 
de limitações e reduções recíprocas para compatibilizá-los sem que se sacrifique totalmente um para o benefício do outro, buscando-se sempre a aplicação máxima de todos.

Essa atividade, entretanto, deve se dar com observância do princípio do devido processo legal, dando-se oportunidade para a manifestação de todos os grupos e centros de interesse, o que se faz fundamental em um Estado pluriclasse ${ }^{106}$. Nota-se, aqui, certa confusão ou sobreposição entre o processo decisório acerca do conteúdo do interesse público, a que se fez referência no item anterior, e o processo de resolução de conflitos entre interesses públicos colidentes de que se trata neste tópico. Nos casos concretos, não basta se apurar se um dado interesse autoriza a atuação estatal, fazendo-se também necessário determinar como pode ser amparado em razão de outros interesses protegidos concorrentes. Partindo da premissa da existência de um interesse público único, o cerne da questão residirá apenas na definição do seu conteúdo.

No âmbito jurídico, distinguem-se os conflitos normativos que se estabelecem entre regras daqueles que se estabelecem entre princípios. Se o conflito consubstanciar uma colisão entre regras jurídicas, de forma que a aplicação de cada uma delas leve a resultados inconciliáveis, então a solução se dá no plano da validade, buscando-se no ordenamento regras para resolução de antinomias com o objetivo de se determinar qual a regra válida e aplicável, sendo comumente empregados o cronológico, o hierárquico e o da especificidade $^{107}$, em razão dos quais, respectivamente, prevalecem as regras posteriores, hierarquicamente superiores e mais específicas ${ }^{108}$.

Se o conflito transparecer a colisão de princípios a respeito dos quais se consagra abstratamente o mesmo nível de proteção de forma a não se admitir que um goze de precedência com relação ao outro de forma absoluta, a solução que se propugna, com base na doutrina alemã, diz respeito ao critério da proporcionalidade. Sua origem remonta a decisões de cortes europeias concernentes a atividades públicas com repercussão negativa

\footnotetext{
106 JUSTEN FILHO, 1999, pp. 132/133.

${ }^{107}$ Lei de Introdução às normas do Direito Brasileiro, Decreto-Lei n 4.657 , de 4 de setembro de 1942, artigo $2^{\circ}$.

${ }^{108}$ Casos há em que a aplicação de uma regra pode ser evitada em razão de uma cláusula de exceção aplicada em um caso como consequência, por exemplo, de um princípio, conforme expõe Robert Alexy ALEXY, Robert. Teoria dos Direitos Fundamentais. 2. ed. Tradução de Virgílio Afonso da Silva. São Paulo: Malheiros, 2011, pp. 92/93 e 104).
} 
na esfera de particulares, exigindo-se do Estado a ponderação dos interesses envolvidos de forma a se certificar de que a finalidade pública buscada justificasse o sacrifício privado incorrido, bem assim tomando-se as medidas necessárias para que tal sacrifício fosse o mínimo possível ${ }^{109}$. Em síntese, propugna pela "manutenção de um justo equilíbrio entre os sacrifícios e os benefícios resultantes da ação administrativa do Estado" ${ }^{110}$. Essa proporcionalidade, no Brasil, assumiu caráter de princípio de Direito Administrativo, encontrando-se implicitamente albergado na esfera constitucional ${ }^{111}$.

A proporcionalidade difundiu-se como critério para resolução de conflitos entre princípios, valores e interesses ${ }^{112}$, tornando-se fundamental para a "avaliação geral da atuação pública" ${ }^{113}$, inclusive no Brasil ${ }^{114}$. Ela se divide em três máximas ${ }^{115}$ ou subcritérios ${ }^{116}$, a saber, o da idoneidade ou adequação; o da necessidade; e o da proporcionalidade em sentido estrito. Pela idoneidade, a medida a ser adotada deve guardar uma relação de adequação com a finalidade almejada, em uma relação de meios e fins congruentes. A máxima da necessidade diz respeito à proibição de excessos, no sentido de que a opção a ser adotada seja aquela que provoque menor gravame aos interesses em conflito, não se justificando qualquer sacrifício além do imprescindível para salvaguardar o outro interesse de mesma estatura. Por fim, o subcritério da proporcionalidade em sentido estrito demanda o sopesamento propriamente dito entre os interesses, ponderando-se os mesmos a fim de se cotejar as vantagens e prejuízos decorrentes. Enquanto as máximas da adequação e da necessidade dizem respeito às possibilidades fáticas, ou seja, a escolha da alternativa adequada que importe o menor sacrifício aos interesses em conflito, a máxima da proporcionalidade em sentido estrito refere-se às possibilidades jurídicas, ou seja, se a medida adequada menos gravosa deve ser adotada ou não em razão do sopesamento dos interesses envolvidos ${ }^{117}$.

\footnotetext{
${ }^{109}$ ARENHART, Sérgio Cruz. A Tutela Coletiva de Interesses Individuais: para além da proteção dos interesses individuais homogêneos. São Paulo: RT, 2013, p. 20.

${ }^{110}$ MOREIRA NETO, 2009, p. 111.

${ }^{111}$ FIGUEIREDO, 2008, pp. 51/52.

112 ALEXY, 2011, pp. 94/95; ARENHART, 2013, pp. 21/22.

${ }^{113}$ ARENHART, 2013, p. 27.

114 "Também o direito brasileiro, seguindo a inspiração europeia, vem utilizando com frequência a noção de proporcionalidade, com clara inspiração na teoria desenvolvida pelo direito alemão. A proporcionalidade, no direito nacional, tem-se pautado pelos testes da idoneidade, necessidade e proporcionalidade em sentido estrito, nos mais diversos campos do direito." (ARENHART, 2013, p. 25).

${ }^{115}$ ALEXY, 2011, p. 116.

${ }^{116}$ ARENHART, 2013, p. 22.

${ }^{117}$ ALEXY, 2011, pp. 116/120.
} 
Se nos conflitos entre regras a questão se coloca no campo da validade, os conflitos entre princípios, enquanto mandamentos de otimização, dão-se na dimensão do peso ${ }^{118}$. Por inexistir uma relação de precedência abstrata, prévia e absoluta entre interesses de igual estatura, a solução para os conflitos têm ponto fulcral na realização do sopesamento entre os princípios colidentes para que no caso concreto se determine qual tem maior peso ${ }^{119}$. Estabelecem-se, assim, condições que presentes no caso concreto devem levar a que um dos interesses preceda o outro por considerar-se aquele de maior peso do que este. Esse é o conceito de relação condicionada de precedência a que alude Robert Alexy como critério para a resolução do embate entre princípios de aplicação incompatível em um caso concreto $^{120}$. Dessa colisão entre princípios que resulta na prevalência de um caso certas condições estejam presentes no caso concreto leva a existência de uma regra tendo por suporte fático as citadas condições e por consequência jurídica aquela resultante do princípio precedente.

Sob o princípio da proteção do núcleo essencial, a solução que se obtenha para o conflito entre interesses protegido não pode ser tal que leve à eliminação de um deles ou à subtração de sua essência. ${ }^{121}$ De forma diversa do conflito entre regras, que levam ao prevalecimento de uma com a total inobservância da outra, nos conflitos entre princípios é possível conceber-se a observância de ambos, por mais que não em sua integralidade. $O$ que se busca é a solução que permita a máxima observância dos princípios em conflito, privilegiando, na medida em que se fizer necessário, aquele que apresente maior peso no caso concreto, o qual poderá não ser o mesmo a prevalecer em outras circunstâncias concretas.

\subsection{INTERESSES DIFUSOS E COLETIVOS}

Em paralelo ao fenômeno do desenvolvimento do Estado pluriclasse e as transformações sofridas pelo conceito de interesse público que levaram à sua multiplicidade e heterogeneidade, novos interesses de caráter metaindividual passaram a ser reconhecidos

\footnotetext{
118 ALEXY, 2011, p. 94.

119 ALEXY, 2011, pp. 94/95.

${ }^{120}$ ALEXY, 2011, pp. 96 ss.

${ }^{121}$ ARENHART, 2013, p. 23.
} 
pelo Direito, bem como mecanismos processuais foram desenvolvidos de forma que pudessem ser efetivamente tutelados.

Aludidos interesses possuíam evidente dimensão social, alcançando grupamentos de pessoas, no mais das vezes desorganizados, e referindo-se a necessidades compartilhadas com um objeto comum. Sua proteção trouxe um impacto político, inserindo os corpos intermediários na gestão da coisa pública, assumindo feições de gestão participativa, e implicando uma nova forma de descentralização, de caráter social, assumindo referidos corpos e formações sociais funções específicas ${ }^{122}$.

Certo é que até então o principal instrumento para a tutela de interesses tansindivuais era o Estado, por meio do interesse público. Os indivíduos que derivassem algum interesse pessoal do conteúdo do interesse geral, no mais das vezes, eram considerados apenas titulares de interesses legítimos, sem que lhes fossem assegurados mecanismos de tutela autônoma. A par do Estado, somente a algumas entidades coletivas, tais como os sindicatos e entidades de classe, eram reconhecidos poderes limitados de buscar o atendimento de interesses transindividuais, no mais das vezes restringindo-se o escopo de proteção aos interesses individuais de seus membros. Nesses casos, não se estaria diante de verdadeiros interesses coletivos, e sim de interesses individuais agrupados.

Ao lado das clássicas liberdades individuais negativas, erigidas a direitos fundamentais de primeira geração ou dimensão, foram assim também reconhecidos como direitos fundamentais, os direitos sociais, ou liberdades positivas, e os direitos de solidariedade, classificados como de segunda e terceira gerações ou dimensões. Nessas se incluíram os direitos coletivos e difusos, incidentes em áreas tais como as relações de trabalho, o meio ambiente e as relações de consumo.

No cenário de insuficiência dos mecanismos processuais existentes para a defesa dos interesses de caráter coletivo, considerando inclusive a incapacidade do Estado de atuar de forma efetiva nesse sentido, inclusive porque, por vezes é o próprio Estado o agente violador a tais interesses, a doutrina passou a sustentar a possibilidade da tutela pelos

122 GRINOVER, Ada Pellegrini. in GRINOVER, Ada Pellegrini; NERY JUNIOR, Nelson; WATANABE, Kazuo. Código Brasileiro de Defesa do Consumidor: comentado pelos autores do anteprojeto, Vol. II: Processo Coletivo (arts. 81 a 104 e 109 a 119), 10. ed. Rio de Janeiro: Forense, 2011, p. 40. 
indivíduos dos interesses metaindividuais veiculados mesmo como interesses legítimos ${ }^{123}$, ou mesmo a extensão do conceito de direito subjetivo para que passassem a abranger tais interesses. José Renato Nalini, a esse respeito, clamava pela revisão do conceito de direito subjetivo para que aquelas definições clássicas, impregnadas que são por noções individualistas, deixassem de ser obstáculo para a tutela de interesses da coletividade ${ }^{124}$.

Por inovações legislativas, contudo, novas classes de interesses coletivos foram reconhecidas e disciplinadas no ordenamento, desenvolvendo-se instrumentos processuais adequados a manejá-los em vista de suas características peculiares. Nessa toada, foram legalmente previstos e definidos os interesses coletivos em duas categorias: os difusos e os coletivos estrito senso. Até a sua definição legal, discutia-se na doutrina se essas expressões eram sinônimas ou se designavam objetos diversos, e, neste caso, como se diferenciavam $^{125}$. Com a estipulação dos seus elementos caracterizadores pela lei, apaziguaram-se os debates em razão de sua inutilidade prática ${ }^{126}$.

A natureza de tais interesses gerou certo debate entre os estudiosos do Direito, despontando questionamentos a respeito de sua caracterização como direitos ou meros interesses. A discussão, contudo, perdeu qualquer relevância pragmática com a Lei 8.078 de 1990 - o Código de Defesa do Consumidor - que além de positivar os interesses difusos e coletivos como categorias jurídicas próprias, fixando os seus critérios caracterizadores ${ }^{127}$, denominou-os de interesses ou direitos, de forma a autorizar o emprego de qualquer dos termos indistintamente, tendo-os como sinônimos ${ }^{128}$.

${ }^{123}$ COSTA, 2009, p. 45.

${ }^{124}$ NALINI, 1985, p. 249.

${ }^{125}$ MANCUSO, 2004, pp.82/86.

${ }^{126}$ BARBOSA MOREIRA, José Carlos. La iniciativa en la defensa judicial de los intereses difusos y colectivos: (un aspecto de la experiencia brasileña). In Temas de Direito Processual: Quinta série. São Paulo: Saraiva, 1994, pp. 163/164.

${ }^{127}$ Há quem critique a lei por definir os elementos caracterizadores dos interesses difusos, coletivos e individuais homogêneos, principalmente porque aludidos conceitos ainda não estavam assentados na doutrina. Nada obstante, é reconhecido o mérito de provocar uma evolução no direio pátrio. (GIDI, 1995, p. 19).

128 "Os termos 'interesses' e 'direitos' foram utilizados como sinônimos, certo é que, a partir do momento em que passam a ser amparados pelo direito, os 'interesses' assumem o mesmo status de 'direitos', desaparecendo qualquer razão prática, e mesmo teórica, para a busca de uma diferenciação ontológica entre eles" (WATANABE, Kazuo. in GRINOVER, Ada Pellegrini; NERY JUNIOR, Nelson; WATANABE, Kazuo. Código Brasileiro de Defesa do Consumidor: comentado pelos autores do anteprojeto, Vol. II: Processo Coletivo (arts. 81 a 104 e 109 a 119), 10. ed. Rio de Janeiro: Forense, 2011, p. 70). 
As restrições quanto à sua caracterização como direito de alguma forma se relacionam a uma potencial enganosa associação com a noção de direito subjetivo, sendo este marcado por sua individualidade e precisa determinação de titularidade, características estas não compartilhadas com os interesses coletivos na sua essência. ${ }^{129}$ Nada obstante, como receberam proteção legal expressa e tornaram-se tuteláveis judicialmente, deixaram de ser meros interesses para constituir verdadeiros direitos, por mais que não subjetivos, e sim direitos metaindividuais ou transindividuais. ${ }^{130}$ Conforme visto, a ideia de interesse comporta qualquer relação de complementariedade entre sujeito e bem, seja ela protegida, vedada ou desprezada pelo Direito. Caracterizá-los como direitos, além de lhes atribuir uma carga semântica qualificada, torna-se um elemento argumentativo em prol de sua proteção em um sistema estruturado em torno do individualismo. Ressalve-se, todavia, que interesses podem se revestir dos caracteres estruturais dos interesses coletivos sem que lhes seja conferida exigibilidade sob a perspectiva jurídica. O interesse de dependentes e outras espécies de usuários pela liberalização do uso de drogas ilícitas, por exemplo, apesar de compartilhado por esse grupo de forma indivisível, por não encontrar fundamento no Direito posto não assume juridicidade. Não se trata, assim, de verdadeiros direitos coletivos.

\subsection{INTERESSES DIFUSOS}

Como interesses coletivos que qualificam, os interesses difusos são marcados, no plano objetivo, pela indivisibilidade ${ }^{131}$. $\mathrm{O}$ seu atendimento ou violação afeta da mesma forma o conjunto composto por seus titulares, por mais que a repercussão pessoal em cada qual seja percebida em graus e intensidades não uniformes. A construção de um aeroporto supersônico em área urbana inadequada representaria lesão ao interesse difuso dos moradores da região, perturbados no seu sossego, por mais que em intensidade maior para aqueles com residência mais próxima às pistas de pouso e decolagem. $\mathrm{O}$ sucesso ou o

\footnotetext{
${ }^{129}$ Observa Antonio Gidi: "os direitos superindividuais, pela indivisibilidade do seu objeto e 'imprecisa' determinação de sua titularidade, se não enquadrariam exatamente na rígida delimitação conceitual do direito subjetivo como fenômeno de subjetivação do direito objetivo" (GIDI, 1995, p. 17). O autor defende, entretanto, que se tratam sim de direitos subjetivos, mesmo que considerado em sentido amplo.

${ }^{130}$ COSTA, 2009, p. 47.

${ }^{131}$ MANCUSO, 2004, pp. 98/100.
} 
fracasso de uma ação judicial visando o embargo da obra afetará a todos no mesmo sentido $^{132}$.

Também por conta do seu caráter coletivo, são insusceptíveis de apropriação exclusiva, configurando o seu objeto bem coletivo ${ }^{133}$. Isso importa afirmar que o maior aproveitamento proporcionado por um interesse difuso para um dos seus beneficiários não acarretará menor aproveitamento para outro, não se estabelecendo um conflito interno a esse respeito.

No que se refere à dimensão subjetiva, ressalta a sua relevância diminuída, ao menos no que toca à identificação de seus titulares, sendo os mesmos indeterminados e indetermináveis ${ }^{134}$. Trata-se de interesses fluidos, com campo subjetivo de abrangência com limites tênues, variável no tempo e no espaço, de forma a ser impossível identificar todos aqueles que o compartilham. Essa característica, no entanto, não os torna menos relevantes, sendo no mais das vezes dotados de grande valor pela sua extensão e efeito no todo, por mais que se disperse na coletividade de modo a repercutir minimamente nas esferas pessoais. A indeterminação dos sujeitos impede sua captação ou atribuição em termos de exclusividade, extrapolando a esfera dos agrupamentos institucionalizados, e assumindo um estado de fluidez no processo social, de modo a serem caracterizados como "interesses em busca de autor" ${ }^{135}$.

O liame a interligar os titulares de modo a que seu objeto assuma contornos de indivisibilidade decorre de elementos fáticos. Nascem, assim, a partir de situações fáticas ${ }^{136}$, prescindindo de qualquer vínculo jurídico, por mais que este ocasionalmente possa vir a existir. Nos casos concretos, como a extensão das situações fáticas expande-se de forma indimensionável, por vezes desencadeando relações de causa e efeito imprevisíveis e impassíveis de apuração na sua integralidade, a identificação dos sujeitos afetados torna-se impossível.

\footnotetext{
${ }^{132}$ MANCUSO, 2004, pp. 98/99.

${ }^{133}$ Para Rodolfo de Camargo Mancuso, "bem difuso" (MANCUSO, 2004, p. 95).

134 "Essa 'indeterminação de sujeitos' deriva, em boa parte, do fato de que não há um vínculo jurídico coalizador dos sujeitos afetados por esses interesses: eles se agregam ocasionalmente, em virtude de certas contingências, como o fato de habitarem certa região, de consumirem certo produto, de viverem numa certa comunidade, por comungarem pretensões semelhantes, por serem afetados pelo mesmo evento originário de obra humana ou da natureza etc." (MANCUSO, 2004, p. 95).

${ }^{135}$ Vincenzo Vigoriti, apud MANCUSO, 2004, p. 92.

${ }^{136}$ COSTA, 2009, p. 47.
} 
Ademais, como se baseiam em elementos fáticos e não de vínculos jurídicos que lhes dessem estabilidade ${ }^{137}$, as alterações factuais levam à mutação desses interesses. Daí porque se afirmar terem duração efêmera ${ }^{138}$ ao se configurarem nas diversas situações da vida. Com o rearranjo das circunstâncias fáticas, se desenham novas formas de expressão de interesses difusos a substituírem as anteriores, estabelecendo uma dinâmica que torna a sua proteção ainda mais complexa.

Também se atribuem aos interesses difusos a característica de apresentarem uma intrínseca conflituosidade, levando à sua constante confrontação com outros interesses, sobretudo também de características coletivas. Aliás, considerando as suas demais características, fica evidente que se concentram maiores atenções aos interesses difusos nas situações em que são lesados ou se encontram sob ameaça de lesão em razão de conflitos com outros interesses. Apesar de sempre ter existido um interesse difuso referente à qualidade do ar atmosférico, nenhuma atenção era a ele dispensado até que as atividades poluidoras, especialmente nos grandes centros industriais, passaram a contaminá-lo de tal modo a causar prejuízos ao bem estar da população.

A esse respeito, aliás, vale notar que dentre os interesses difusos tidos por mais típicos está o direito ao meio ambiente ecologicamente equilibrado. Por mais que tal direito, de natureza fundamental, pertença aos membros de toda a coletividade, sua violação em um caso concreto não importará necessariamente prejuízo a todos. A emissão de efluentes em um corpo d'água, por exemplo, pode ter efeitos restritos no espaço e no tempo. Em virtude da cadeia de causalidade que gera, a repercussão do desequilíbrio provocado é impassível de medição com precisão. Nesse sentido, além dos moradores da região, também aqueles que por lá transitam ou que consomem produtos contaminados pela poluição. Ao se efetivar a lesão ambiental, o interesse na sua formatação original terá perecido, sendo reformulado ou substituído por outro em virtude da mudança do objeto. Por mais que recomposto o meio ambiente lesado ou procedida a compensação ambiental, a nova realidade não será a mesma da antecedente. A atividade poluidora, ademais, pode estar relacionada a interesses relevantes que contrastariam com aquele referente à qualidade

\footnotetext{
${ }^{137}$ MANCUSO, 2004, p. 111.

${ }^{138}$ MANCUSO, 2004, pp. 106/110.
} 
ambiental, como, por exemplo, a produção de armamentos ou medicamentos em um período de guerra ou de epidemia.

A relativa pequena relevância na esfera individual e sua imanente conflituosidade acarretam a fragilização da proteção dos interesses difusos em um sistema individualista. $\mathrm{O}$ exame do custo benefício envolvido, no mais das vezes, leva os indivíduos a preterirem a sua defesa. A sua subrepresentação desencoraja seu encampamento como interesse público pelas autoridades públicas, no mais das vezes influenciadas pelas pautas dos grupos de pressão. Mesmo que superados esses entraves, eventual tentativa de defesa esbarraria na impossibilidade de definição dos seus titulares, sob o entendimento de que "se um interesse pertine a todos, não pertine a ninguém, e assim não é tutelável" ${ }^{139}$. Nesse cenário, sua definição legal como um interesse com titularidade indeterminável teve o mérito de tornar inócuas discussões a respeito da identificação dos sujeitos beneficiados pela tutela. A proteção deixa de ser em razão da titularidade para focar na sua relevância social ${ }^{140}$.

Entre outras características atribuídas aos interesses difusos, destacam-se as esquematizadas por Rodolfo de Camargo Mancuso, sendo elas: a) a indeterminação dos sujeitos; b) a indivisibilidade do objeto; c) a intensa conflituosidade; e d) a duração efêmera, contingencial ${ }^{141}$.

Rodolfo de Camargo Mancuso apresenta a seguinte definição de interesses difusos:

são interesses metaindividuais, que, não atingindo o grau de agregação e organização necessários à sua afetação institucional junto a certas entidades ou órgãos representativos dos interesses já socialmente definidos, restam em estado fluido, dispersos pela

\footnotetext{
${ }^{139}$ MANCUSO, 2004, p. 89.

${ }^{140}$ MANCUSO, 2004, p. 93. O fenômeno de reconhecimento e proteção desses direitos "não-subjetivados", é reconhecido por Ovídio Baptista da Silva: "Dá-se nas sociedades contemporâneas, pós-industriais, a tendência inversa, por meio da qual se busca legitimar determinadas situações jurídicas, como as denomina PAUL ROUBIER (Droits subjectives et situations juridiques, 1963), supra-individuais, como interesses sociais de grupos, tutelados, como simples interesses, ou como direitos "não-subjetivados", a que a lei reconhece status jurídico similar ao dos direitos individuais. A proteção aos chamados "interesses difusos" é um exemplo marcante desta tendência, que se poderia indicar como "socialização" do direito subjetivo. Daí a referência, no dispositivo constitucional, a "direitos coletivos" ao lado de "direitos individuais"." (BAPTISTA DA SILVA, Ovídio A. Curso de Processo Civil, vol.1: processo de conhecimento. 4. ed. São Paulo: RT, 1998, p. 486).

${ }^{141}$ MANCUSO, 2004, p. 93 e seguintes.
} 
sociedade civil como um todo (v.g., o interesse à pureza do ar atmosférico), podendo, por vezes, concernir a certas coletividades de conteúdo numérico indefinido (v.g., consumidores). Caracterizam-se: pela indeterminação dos sujeitos, pela indivisibilidade do objeto, por sua intensa litigiosidade interna e por sua tendência à transição ou mutação no tempo e no espaço ${ }^{142}$.

\subsection{INTERESSES COLETIVOS EM SENTIDO ESTRITO}

Os interesses coletivos também apresentam como característica a indivisibilidade do objeto, além da titularidade metaindividual. São, todavia, menos esparsos do que os interesses difusos, referindo-se a um grupo, categoria ou classe de pessoas específico, de forma a se tornar possível a identificação de seus membros.

José Carlos Barbosa Moreira reconhece que ambas as espécies de interesses, difusos e coletivos, marcam-se pela transindividualidade e pela natureza indivisível, de modo que a tutela ou a violação para um signifique a mesma tutela ou violação para todos. A principal diferença, da qual decorreriam suas características próprias, residiria na existência de uma relação jurídica a embasar os interesses coletivos ${ }^{143}$.

Formam-se tais interesses em função de um vínculo jurídico comum que une os membros do grupo, categoria ou classe, em razão do qual decorre a sua unicidade, permitindo a determinação dos seus titulares. ${ }^{144}$ Considera-se, conforme a definição legal, tal vínculo decorrente de uma relação jurídica base estabelecida entre os membros daquela coletividade ou deles com a parte adversa. A conflituosidade é tão relevante para a formação e perseguição dos interesses transindividuais que a própria norma prevê como elemento do interesse coletivo a existência de uma parte contrária, pressupondo que com ela se estabeleça um conflito.

Diz-se serem os interesses coletivos institucionalizados, encampados por entidades associativas dos membros do grupo, classe ou categoria a que pertencem. A possibilidade

\footnotetext{
${ }^{142}$ MANCUSO, 2004, p. 150.

143 BARBOSA MOREIRA, 1994, pp. 164.

${ }^{144}$ COSTA, 2009, p. 51.
} 
de determinação dos seus titulares por um vínculo jurídico que os aproxima, enseja a sua organização em torno desse interesse, levando ao surgimento de entes próprios para a sua defesa. Trata-se, assim, de um interesse corporativo ${ }^{145}$, muito embora a lei não imponha essa organização como um elemento essencial do interesse ou da sua proteção ${ }^{146}$.

O que se nota em relação a essas duas categorias de interesses metaindividuais é que, nada obstante se refiram a uma coletividade, bem ou mal definida, apresentam uma dimensão pessoal, causando impacto direto na esfera particular dos seus titulares. Nesse sentido, Susana Henriques da Costa afirma:

Os interesses coletivos, assim como os difusos, permitem a fruição direta de um benefício fático por seus membros. É o que ocorre, por exemplo, quando se define e se respeita determinada norma que prevê limites para o reajuste de mensalidades escolares. Todos os componentes da coletividade de alunos de uma determinada escola serão atingidos pela norma, de forma concreta ${ }^{147}$.

\subsection{RELAÇÃO ENTRE INTERESSES DIFUSOS E COLETIVOS COM O INTERESSE PÚBLICO}

Questão que se coloca diz respeito à interação entre os conceitos de interesse público e interesses coletivos, sobretudo no que toca determinar se constituem categorias de interesses distintas ou se correspondem a formas diversas de qualificar interesses de modo a que um mesmo possa estar em ambas as categorias.

Para Marçal Justen Filho, os interesses difusos e coletivos, apesar de transindividuais não deixam de ser interesses privados. ${ }^{148}$

\footnotetext{
${ }^{145}$ COSTA, 2009, p. 50.

146 "A qualificação do interesse coletivo é jurídica, não fática. O que juridicamente empresta ao interesse a característica de coletivo não é a constatação dos sujeitos envolvidos estarem ou não organizados, mas a possibilidade do bem em questão ser atribuído a uma coletividade específica. Nesse sentido, a possibilidade de atribuição de um bem a um grupo ou uma classe não está condicionada à existência de vínculos organizacionais entre os sujeitos implicados" (SALLES, 1999, p. 140).

${ }^{147}$ COSTA, 2009, p. 51.

148 JUSTEN FILHO, 1999, p. 122.
} 
Segundo Ada Pellegrini Grinover, os interesses coletivos encontram-se entre os privados e os públicos. Enquanto o interesse público diz respeito ao Estado, tendo todos os cidadãos como partícipes e podendo gerar conflitos entre o indivíduo e o Estado; e o interesse privado é de titularidade individual, colocado na dimensão dos direitos subjetivos e gerando conflitos entre indivíduos em relações jurídicas de credor e devedor; os interesses coletivos, ou sociais, seriam pertinentes a um grupo de pessoas apenas, correspondendo a necessidades coletivas e convergindo para um objeto comum e indivisível, contrastando com outros interesses de outros grupos ${ }^{149}$.

Diogo de Figueiredo Moreira Neto, de outro modo, aponta traduzirem classificações distintas de interesses baseadas em critérios próprios. Enquanto a tradicional distinção entre interesses públicos e privados teria por critério a relevância dos mesmos para o Estado; a distinção moderna entre interesses individuais (e individuais homogêneos), coletivos e difusos se basearia em critérios como a transindividualidade, a divisibilidade e a solidariedade ${ }^{150}$.

Em sentido semelhante, José Cretella Junior afirma não se confundirem as noções de interesse público e interesse coletivo. Admite, entretanto, que o interesse coletivo possa configurar interesse público mediante a sua atribuição ao Estado como interesse próprio ${ }^{151}$.

Rodolfo de Camargo Mancuso, valendo-se do critério da dimensão de sua titularidade, classifica os interesses em cinco graus crescentes de coletivização: a) individuais - sujeitos à captação e fruição individual isolada; b) sociais - pertencentes a pessoa jurídica como o conjunto de interesses pessoais de seus membros; c) coletivos - ligados a grupos sociais ou categorias definidos; d) público ou coletivo - atomizado e compartilhado por toda a coletividade representada pelo Estado e substancializando standards sociais; e e) difusos -

\footnotetext{
${ }^{149}$ GRINOVER, 2011, p. 40. No mesmo sentido, Hugo Nigro Mazzilli afirma que: "Situados numa posição intermediária entre o interesse público e o interesse privado, existem os interesses transindividuais (também chamados de interesses coletivos, em sentido lato), os quais são compartilhados por grupos, classes ou categorias de pessoas (como os condôminos de um edifício, os sócios de uma empresa, os membros de uma equipe esportiva, os empregados do mesmo patrão). São interesses que excedem o âmbito estritamente individual, mas não chegam propriamente a constituir interesse público" (MAZZILLI, 2007, p. 48).

${ }^{150}$ MOREIRA NETO, 2009, p. 7.

151 "Não se confundem interesses públicos com interesses coletivos. Ao interesse particular dum só indivíduo podem corresponder interesses dum grupo de indivíduos, interesses particulares coletivos ou interesses coletivos. Surge o interesse público quando o Estado coloca determinado interesse coletivo entre seus próprios interesses." (CRETELLA JÚNIOR, José. Tratado de Direito Administrativo: teoria do direito administrativo, vol. I, 2. ed., Rio de Janeiro: Forense, 2002, p. 53)
} 
extrapolando a abrangência do interesse público, eis que não sofrem limitações para adequarem-se a "valores pacificamente aceitos", permitindo qualquer sorte de posicionamento, com alto índice de desagregação ou atomização permitindo sua extensão por um contingente indefinido de indivíduos ${ }^{152}$.

Para Cristiane Derani, interesse público é expressão que contempla o interesse das pessoas enquanto inseridas no espaço público, ou seja, nas suas relações sociais. Assim, "interesse público é o interesse dos indivíduos em sociedade, no que concerne a sua inserção e convivência social". Sob essa perspectiva, no contexto do Estado Democrático de Direito, interesse público e interesse coletivo, enquanto interesse da coletividade, são sinônimos. Nada mais é o interesse público do que o interesse coletivo "identificado pelo Estado no desenvolvimento de suas políticas". Não se trata, assim, de interesse do Estado ou do governante, mas da coletividade. ${ }^{153}$ Serve o Direito como instrumento de vinculação do Estado ao interesse público.

Com base em classificação de Maria Sylvia Zanella di Pietro ${ }^{154}$, Susana Henriques da Costa, equiparando o interesse público à busca do bem comum, ou os valores fundamentais da sociedade, identifica o interesse geral, os interesses difusos e os interesses coletivos como espécies do gênero interesse público, dispostos em ordem decrescente de dispersão e fluidez. O interesse geral apresentaria o grau máximo, referindo-se à totalidade da comunidade política, enquanto os interesses difusos e coletivos pertenceriam a coletividades mais limitadas ${ }^{155}$.

Outro ponto de diferenciação reside na completa desvinculação da efetivação do interesse geral com o atendimento direto de qualquer interesse individual. Tratando-se de interesse geral, o aproveitamento direto resultante para um ou mais sujeitos será eventual e não necessário. Proporcionando benefício direto a um sujeito ou a um vasto grupo, na medida em que diga respeito a necessidades compartilhadas por toda a comunidade política, não deixará de ser interesse geral. A prisão de uma quadrilha de sequestradores pela polícia

\footnotetext{
${ }^{152}$ MANCUSO, 2004, pp. 86/87.

${ }^{153}$ DERANI, 2002, pp. 46/47.

${ }^{154}$ DI PIETRO, 2007, pp. 224/226.

155 Nesse sentido, Ada Pellegrini Grinover distingue aludidos interesses metaindividuais dos interesses difusos e coletivos justamente por aqueles se estenderem a todos (GRINOVER, Ada Pellegrini. A Tutela Jurisdicional dos interesses difusos. In: Revista de Processo, N. 14/15, ano 6, 1979, p. 27).
} 
será medida de interesse comum alusivo à segurança pública, por mais que beneficie diretamente apenas a vítima que estivesse na ocasião em cativeiro.

Os interesses difusos e coletivos, também expressões do interesse público, voltam-se à satisfação de necessidades concretas dos membros de uma dada coletividade, implicando, desse modo, "a fruição efetiva e direta de um benefício/prejuízo por parte de seus membros" ${ }^{156}$.

Uma vez que o conceito de interesse público assumiu novas feições, deixando de ser único e homogêneo para ser plúrimo e heterogêneo, razões há para se afirmar que os interesses ou direitos coletivos representam espécie de interesse público. Aliás, não seria despropositado afirmar que foram um dos principais responsáveis pela reconfiguração do que vem a se entender por interesse público. Os autores que defendem inexistir uma sobreposição de objeto parecem se apoiar em uma visão tradicional do interesse público, equiparando-o às noções generalizantes de interesse geral e bem comum, que passaram a representar uma das feições do interesse público.

Embasando tal entendimento, tem-se que ao Estado foi atribuída a função de tutelar os interesses difusos e coletivos, não apenas no exercício da função jurisdicional, como também na legislativa e executiva, o que não podia ser diferente eis que aludidos interesses encontram correspondência em direitos fundamentais de segunda e terceira dimensões. Cite-se, exemplificativamente, o Sistema Nacional de Defesa do Consumidor previsto pelo Código de Defesa do Consumidor, do qual fazem parte os Procons estaduais e municipais espalhados pelo país, em conjunto com outros órgãos públicos e entidades privadas destinadas à defesa do consumidor. Violações das normas protetoras do consumidor, nos termos do Código, podem caracterizar, além de ilícito civil e penal, infração administrativa sujeita a sanções aplicadas por autoridade administrativa, conforme dispõe seu artigo 56. Também os artigos $4^{\circ}$ e $5^{\circ}$ preveem a Política Nacional das Relações de Consumo, estabelecendo princípios, diretrizes e instrumentos para o Poder Público na área do consumo.

${ }^{156}$ COSTA, 2009, p. 64. 
$2^{\mathrm{a}}$ PARTE - COlETIVIZaÇão PROCESSUal: AS AÇõeS COLETIVAS 


\section{CAPÍTULO 1. PROCESSOS COLETIVOS}

\subsection{PROCESSO INDIVIDUAL PARA O COLETIVO}

Em um primeiro plano, as normas de direito material ao reconhecerem interesses e lhes conferirem juridicidade têm o condão de estabelecer um parâmetro para a resolução de conflitos de interesses intersubjetivos, cuja ocorrência é ínsita à vida do homem em sociedade. Contrapondo-se interesses de diferentes sujeitos, de forma que cada qual se predisponha a fazer o seu prevalecer, sendo as partes incapazes de encontrar uma solução econômica ou ética para o conflito, servirá o direito, e os valores por ele incorporados, como referencial para a apuração de qual interesse há de preceder sobre o outro ${ }^{1}$.

Sob outra perspectiva, também representa o direito um instrumento para a seleção de interesses em torno dos quais a coletividade, principalmente por intermédio do Estado, reunirá esforços e recursos para dar atendimento. Além de organizar a cooperação dos membros da coletividade, aqui, novamente, o direito servirá como parâmetro para a resolução de conflitos de interesses. No universo de interesses existentes, não serão todos passíveis de atendimento, sobretudo em função da limitação dos recursos à disposição do Estado. A escolha daqueles tidos por mais relevantes representa, assim, uma forma de resolução de conflitos pela alocação de bens e recursos coletivos ${ }^{2}$.

Exerce o Direito, assim, função ordenadora da sociedade "isto é, de coordenação dos interesses que se manifestam na via social, de modo a organizar a cooperação entre pessoas e compor os conflitos que se verificarem entre os seus membros" ${ }^{3}$. Para José Roberto dos

\footnotetext{
${ }^{1} \mathrm{O}$ que se nota, no mais das vezes, é que mesmo as soluções econômicas e éticas dos conflitos sofrem influência das normas jurídicas incidentes sobre o caso. Um sujeito cujo interesse corresponda a um direito normalmente imporá maiores entraves para se sujeitar ao interesse contraposto do outro.

2 "O homem é um ser social dotado de interesses próprios. A sociedade é o ambiente de sua existência. Nela estarão em contato a multiplicidade de interesses, muitos nitidamente conflitantes, cuja oposição levada ao extremo conduz à desintegração do agrupamento. A sociedade moderna encontra no Estado e no direito a forma de manutenção social. Organiza-se em vista da sua integração. Para isso, uma série de atividades são desenvolvidas, paralelas àquelas iniciadas pelo interesse individual. São atividades definidas pelo direito, conduzidas pelo Estado, o qual tem sua origem motriz no interesse da coletividade, que é traduzido, em última análise, no interesse de integração social." (DERANI, 2002, p. 52).

3 ARAÚJO CINTRA, Antonio Carlos de; GRINOVER, Ada Pellegrini; DINAMARCO, Cândido Rangel. Teoria Geral do Processo. 25. ed. São Paulo: Malheiros, 2009, p. 25.
} 
Santos Bedaque, "O direito material ou substancial é formado por um conjunto de regras abstratas de conduta, destinadas à solução de conflitos de interesses entre as pessoas, determinando qual deve prevalecer e conferindo situação de vantagem ao seu titular" ${ }^{4}$.

A causa do Direito decorreria da intenção dos homens de evitarem o uso da violência, o que representaria um risco à paz social capaz de obstacularizar a vida em comunidade, prejudicando o desenvolvimento dos interesses coletivos. A solução pacífica, ou composição dos conflitos, consubstancia, assim, interesse coletivo público, a que Francesco Carnelutti denomina interesse externo ${ }^{5}$. Segundo afirma, a relevância de tal interesse é tamanha que a sua própria existência muitas vezes seria capaz de impulsionar as partes a encontrarem uma solução pacífica para o conflito, baseadas naquela avaliação econômica de ganhos e riscos ${ }^{6}$.

O Direito, por si só, todavia, pode não ser capaz de evitar ou eliminar conflitos intersubjetivos. Por mais que uma sua pretensão encontre correspondência na norma jurídica, o sujeito pode ficar privado de um pretendido bem ou porque encontra a resistência do outro indivíduo que poderia satisfazê-la, ou porque o próprio direito não permite a satisfação voluntária da mesma, de forma a gerar um estado de insatisfação. O conflito de interesses sem solução, sobretudo ao significar a violação de uma norma de direito material em desfavor de uma parte, caracteriza um fator de desagregação social. A indefinição de situações é motivo de angústia, tensão individual e social ${ }^{7}$.

Além das normas de direito material, assim, são necessários mecanismos de resolução de disputas, prevenindo o uso da violência e da autotutela. O próprio Estado, reservando-se o monopólio do uso da força, assume a função de oferecer o processo civil como um mecanismo de solução de controvérsias, ou técnica de solução imperativa de conflitos ${ }^{8}$. É o processo civil um monopólio estatal, legitimador da decisão dele resultante, e obrigatório, na medida em que independe da vontade do réu para que seja instaurado e que tenha curso 9 .

\footnotetext{
${ }^{4}$ BEDAQUE, José Roberto dos Santos. Tutela Cautelar e Tutela Antecipada: Tutelas Sumárias e de Urgência (tentativa de sistematização). 5. ed. São Paulo: Malheiros, 2009, p. 11.

${ }^{5}$ CARNELUTTI, 2000, p. 63.

${ }^{6}$ CARNELUTTI, 2000, p. 63.

${ }^{7}$ ARAÚJO CINTRA; GRINOVER; DINAMARCO, 2009, p. 26.

${ }^{8}$ DINAMARCO, 2005, p. 54.

${ }^{9}$ Não é o processo, todavia, o único mecanismo de resolução de disputas.
} 
Sob o viés dinâmico, a relação jurídica, entendida na perspectiva estática como uma forma de "coordenação da vontade de seus titulares" ${ }^{10}$, dá ensejo à pretensão, consistente da "exigência da subordinação do interesse alheio ao interesse próprio". ${ }^{11}$ Nessa situação, o titular do interesse contraposto pode resignar-se e acatar a exigência, pondo um fim pacífico no conflito, ou a ela resistir, nascendo, assim a lide, definida por Francesco Carnelutti como "o conflito de interesses qualificado pela pretensão de um dos interessados e pela resistência do outro" ${ }^{12}$. Nesse contexto, Francesco Carnelutti define processo como a operação mediante a qual se obtém a justa composição da lide.

Segundo a clássica doutrina de Giuseppe Chiovenda, serviria o processo para a atuação da vontade concreta do direito material ${ }^{13}$. Esse escopo jurídico do processo sempre teve grande significância e influenciou a construção dos sistemas processuais.

De fato, a ligação do processo com o direito material tem origem histórica. No chamado período sincrético, o direito processual não existia como um ramo próprio da ciência do direito, sendo compreendido como parte do direito privado. Cândido Rangel Dinamarco nota que "uma das mais sintomáticas características desse sincretismo inicial, responsável pela colocação do sistema processual nos quadrantes do direito privado, era a visão do processo como mero modo de exercício dos direitos" ${ }^{14}$. Conforme visto, o conceito de direito subjetivo tinha como uma de suas marcas a possibilidade do seu titular exercê-lo em juízo. Tratava-se do domínio de sua vontade, em respeito à sua liberdade individual ${ }^{15}$.

Com base nessa concepção do fenômeno jurídico, estruturou-se o processo civil, tendo por parâmetro o conflito de interesses individuais, fundado no exercício ou tutela do direito

\footnotetext{
${ }^{10}$ CARNELUTTI, 2006, p. 92.

${ }^{11}$ CARNELUTTI, 2006, p. 93.

${ }^{12}$ CARNELUTTI, 2006, p. 93.

${ }^{13}$ DINAMARCO, 2005, p. 151.

${ }^{14}$ DINAMARCO, 2005, p. 274.

15 "Tinha-se, até então a remansosa tranquilidade de uma visão plana do ordenamento jurídico, onde a ação era definida como o direito subjetivo lesado (ou o resultado da lesão ao direito subjetivo), a jurisdição como sistema de tutela de direitos, o processo como mera sucessão de atos (procedimento); incluíam a ação no exercício dos direitos (jus quod sibi debeatur, judicio persequendi) e o processo era tido como conjunto de formas para esse exercício, sob a condução pouco participativa do juiz. Era o campo mais aberto, como se sabe, à prevalência do princípio dispositivo e ao da plena disponibilidade das situações jurídico-processuais que são diretos descendentes jurídicos do liberalismo politico então vigorante (laissez faire, laissez passer et le monde va de lui meme)." (DINAMARCO, Cândido Rangel. A Instrumentalidade do Processo. 9. ed. Malheiros: São Paulo, 2001, p. 18).
} 
subjetivo do autor. ${ }^{16}$ Como fora desenvolvido fundamentalmente sob o modelo de tutela de interesses individuais, tradicionalmente volta-se o seu instrumental para o tratamento de conflitos travados essencialmente entre dois sujeitos com relação a interesses que lhes sejam próprios. O tratamento adequado dos conflitos que transcendem a esfera individual deveria se dar por intermédio da função legislativa ou executiva do Estado $^{17}$.

Lembre-se que os interesses metaindividuais eram concebidos na esfera pública, sendo o Estado incumbido de protegê-los por meio do interesse público, por ato de sua própria iniciativa, não demandando para tanto o exercício da função jurisdicional, podendo fazer prevalecer sua vontade por meio de princípios como o da auto-executoriedade dos atos administrativos. Mesmo no caso de violação pelo Estado de direitos fundamentais dos cidadãos, era a eles que cabia se socorrerem do Judiciário, de forma que o interesse defendido seria de natureza individual. No mais, o interesse público era personificado no Estado, de modo a assumir feições de interesse individual, por mais que estatal. Em um polo, o cidadão, e no outro, o Estado.

$\mathrm{Na}$ evolução histórica do processo, naquela fase a que veio a se denominar autonomista ou conceitual, constituiu um marco a sua ruptura ${ }^{18}$ com o direito material, em razão do que pode assumir autonomia, fomentando o desenvolvimento dos princípios e institutos processuais constituintes das bases para o nascimento da ciência processual. ${ }^{19}$ Diferenciouse a relação jurídica material, e as obrigações, direitos e situações subjetivas a ela atinentes, da relação jurídica processual, decorrente do exercício do direito de ação, com direitos, ônus, poderes e deveres próprios e independentes daqueles de direito material.

Dessa fase veio o reconhecimento de que o direito de ingressar em juízo e obter um provimento jurisdicional de mérito não exigia um direito subjetivo material subjacente. ${ }^{20}$

\footnotetext{
${ }^{16}$ MANCUSO, 2004, p. 89.

${ }^{17}$ MANCUSO, 2004, p. 159.

${ }^{18}$ MANCUSO, 2004, p. 154.

19 "Longas e profícuas discussões doutrinárias em torno dos institutos fundamentais, como jurisdição, ação, exceção, processo, coisa julgada, objeto do processo e outros mais, deram frutos importantes para a afirmação do Direito Processual como ramo autônomo da Ciência do Direito" (WATANABE, Kazuo. Da Cognição no Processo Civil. 2. ed. Atual. São Paulo: Central de Publicações Jurídicas: Centro Brasileiro de Estudos e Pesquisas Judiciais, 1999, p. 20).

${ }^{20}$ Aliás, nota-se que mesmo que haja um direito subjetivo material subjacente, pode não se apresentar o direito ao provimento jurisdicional de mérito. Sem que o direito subjetivo seja violado ou se encontre sob ameaça, não nasce uma pretensão. Existindo uma pretensão, sem que, contudo, seja resistida pela outra parte ou sem que se imponha a intervenção judicial em razão da relevância do interesse envolvido, não se obterá
} 
Isso se dá, por exemplo, nas situações em que a demanda tem por objeto a declaração de inexistência de certa relação jurídica - conhecida como demanda declaratória negativa, sendo certo que do processo poderá resultar uma decisão de procedência em que justamente se reconheça inexistir qualquer direito subjetivo. Ademais, também desponta o direito à obtenção ao provimento jurisdicional de mérito caso se apure que o autor não é titular do direito subjetivo que alega, apesar de que, nesse caso, a decisão resultante será de improcedência. Isso decorre da constatação de que o objeto do direito de ação consiste na obtenção de um provimento jurisdicional de mérito, e não a um provimento de procedência. Por fim, outros casos há em que sequer se alega ou se discute um direito subjetivo material, concebendo-se os processos cujo objeto também diga respeito a uma relação jurídica processual, como, por exemplo, uma ação rescisória em que se pleiteie a rescisão de uma sentença transitada em julgado proferida por juiz absolutamente incompetente ${ }^{21}$.

Essa dissociação entre os planos material e processual teve o mérito de libertar conceitualmente o direito processual das amarras do direito subjetivo, desenvolvendo-se o conceito de ação de forma desvinculada do direito material. O processo deixou de ser visto como mero "modo de exercício dos direitos" para ser compreendido como método para o recebimento da proteção do Estado-juiz, por meio da tutela jurisdicional ${ }^{22}$.

Desvincilhando-se a ação do direito material, assumiu aquela feições de direito público. A relação jurídica de direito processual diferenciou-se da relação jurídica de direito material subjacente, cada qual contendo elementos próprios. Por mais que o liame entre credor e devedor seja de direito privado, a ação é exercida não em face do réu-devedor, mas do Estado-juiz, a quem corresponde o dever de prover a solução do conflito que lhe é colocado pelas partes. ${ }^{23}$

Formou-se, assim, a base para o desenvolvimento de uma visão publicista do processo, por mais que a muitos de seus institutos fossem mantidas cores privatistas. O foco dos processualistas sobre temas como a ação e a pretensão revelam a preocupação com o

uma decisão a respeito do mérito da demanda porquanto faltará ao autor interesse processual, uma das condições da ação.

${ }^{21}$ MANCUSO, 2004, p. 155.

${ }^{22}$ DINAMARCO, 2005, p. 275.

${ }^{23}$ DINAMARCO, 2001, p. 44. 
direito subjetivo subjacente, levando a um desbalanceamento do processo em favor do autor e dos poderes a ele atinentes. Tal fenômeno leva Cândido Rangel Dinamarco a afirmar ter sido a:

ciência processual construída mediante afirmações e pressupostos publicistas, mas revelando surpreendentes posicionamentos sobrevivos ao sincretismo privatista já superado. Seguramente, concorreu para essa predisposição psicológica a origem do direito processual civil, que hoje unanimemente se reconhece ser ramo do direito público, nos compartimentos do direito privado ${ }^{24}$.

Modernamente, desenvolveu-se a fase instrumentista ou teleológica do processo civil. Partindo da constatação de que não é um fim em si mesmo, sobrepõe-se o caráter instrumental ou teleológico do processo, ou seja, concebe-se o processo como instrumento voltado ao atendimento de certas finalidades que não lhe sejam internas. A partir da fixação desse pressuposto, o processo, como técnica que é, submeteu-se à tendência de ter seus regramentos e institutos configurados com vistas aos escopos a ele atribuídos. Fala-se, nesse tocante, em um processo civil de resultados, legitimando-se na medida em que seja um mecanismo efetivo de implementação das transformações que dele se espera ${ }^{25}$.

Mais do que um instrumentalismo meramente formal, preocupado com a correlação lógica entre o direito material e o direito processual, propugna-se por um instrumentalismo substantivo, buscando o redimensionamento metodológico de institutos e o desenvolvimento de mecanismos processuais de forma a tornar o processo apto a produzir resultados efetivos, a fim de cumprir os escopos que lhe são designados, dos quais se pode depreender as funções a serem desempenhadas e as finalidades a se alcançar ${ }^{26}$.

\footnotetext{
${ }^{24}$ DINAMARCO, 2001, p. 46.

25 "Aprimorar o serviço jurisdicional através do processo, dando efetividade aos seus princípios formativos (lógico, jurídico, político, econômico), é uma tendência universal, hoje. E é justamente a instrumentalidade que vale de suficiente justificação lógico-jurídica para essa indispensável dinâmica do sistema e permeabilidade às pressões axiológicas exteriores: tivesse ele seus próprios objetivos e justificação autosuficiente, razão inexistiria, ou fundamento, para pô-lo à mercê das mutações políticas, constitucionais, sociais, econômicas e jurídico-sociais da sociedade." (DINAMARCO, 2001, p. 24).

${ }^{26}$ SALLES, 2000, pp 45/46.
} 
Nessa perspectiva, ponto fulcral para o sistema diz respeito à identificação desses escopos, ou seja, os fins a que se destina como instrumento do poder estatal. ${ }^{27}$ Somente com base nessa determinação é que se faz adequado investigar em que medida aludidos escopos estão sendo alcançados na prática, de modo a se aprimorar os mecanismos processuais tornando-o mais aderente à realidade em que incide, e, assim, de maior utilidade ${ }^{28}$.

Em primeiro lugar, aponta-se como escopo do processo aquele de ordem jurídica, de realização do direito material. ${ }^{29}$ Daí porque os debates e construções teóricas que marcavam o período abstrativista do processo e a consolidação do direito processual como ramo científico autônomo, deram lugar à busca de mecanismos eficazes de resolução dos litígios por ele veiculados com vista à realização do direito material ${ }^{30}$, assegurando sua conexão com a realidade material e evitando a abstrativização excessiva.

A relação de instrumentalidade entre direito processual e direito material adquire contornos tais que Carlos Alberto Salles defende se tratar de verdadeira relação de interdependência, também dependendo o direito o material do processual para ser implementado ${ }^{31}$. Por mais que não se negue a possibilidade dos sujeitos cumprirem espontaneamente as normas jurídicas que regem sua conduta, faz-se imprescindível um mecanismo de imposição de aludidas normas sob pena de perderem seu caráter coercitivo, assumindo feições semelhantes a regras éticas.

Não se nega sempre ter havido uma ligação entre direito material e processo, confundindose ambos no período sincretista e mantendo-se o elo na fase autonomista, por mais que

\footnotetext{
${ }^{27}$ DINAMARCO, 2001, p. 149.

28 "A tomada de consciência teleológica tem, portanto, o valor de possibilitar o correto direcionamento do sistema e adequação do instrumental que o compõe, para melhor aptidão a produzir tais resultados." (DIANAMARCO, 2001, p. 151).

${ }^{29}$ Cândido Rangel Dinamarco alerta, entretanto, que o escopo do processo não é a tutela de direitos, visão esta que configuraria reminiscência da visão ligada ao sincretismo privatista. Hoje, entende-se "que a tutela jurisdicional é dada às pessoas, não aos direitos, e somente àquele sujeito que tiver razão: a tutela dos direitos não é o escopo da jurisdição nem do sistema processual" (DINAMARCO, 2001, p. 151).

${ }^{30}$ COSTA, 2009, p. 117.

${ }^{31}$ SALLES, Carlos Alberto de. Processo Civil de interesse público. In: SALLES, Carlos Alberto de (Org.) Processo Civil e Interesse Público: o processo como instrumento de defesa social. São Paulo: Revista dos Tribunais, 2003, pp. 45/46. Para José Roberto dos Santos Bedaque, o direito processual tem função instrumental voltada à regulamentação dos mecanismos para a eliminação das crises decorrentes do descumprimento das normas de comportamento previstas no plano material. Por outro lado, o próprio direito material também depende do direito processual, sob pena de carecer de coercitividade, eis que vedada a autotutela (BEDAQUE, 2009, p. 12).
} 
limitado a uma correlação conceitual no plano jurídico ${ }^{32}$. Agora, entretanto, tal ligação se fortalece e assume nova feição. Mais do que a mera correlação conceitual entre os institutos de direito material e de direito processual, a atenção se focaliza na efetividade do processo em dar atendimento ao que determina o direito material.

Nessa perspectiva, revigora-se o movimento de publicização do processo no século $\mathrm{XX}{ }^{33}$ O exercício da jurisdição, além de visar a efetivação de direitos subjetivos e a resolução de conflitos particulares, passa a ser visto como um meio para a efetivação do direito objetivo e a preservação do ordenamento jurídico. ${ }^{34}$ Nota-se a existência do interesse estatal na resolução dos conflitos que lhe são trazidos na esfera judicial, de modo a que o desempenho dessa função venha a extrapolar a esfera de interesses das partes litigantes ${ }^{35}$.

Nesse tocante, defende-se que o processo não deva se restringir a atender seu escopo jurídico, admitindo-se que o sistema processual é aberto e legitimado pelos serviços prestados à comunidade. Como expressão do poder, a jurisdição se volta à realização dos fins do Estado, os quais assumiram uma vasta amplitude nos países em que se introduziram elementos do Estado social. Desse modo, possui o processo implicações políticas e sociais, fora da esfera interna jurídica. Servindo como instrumento de transformação também nessas esferas, há de se lhe atribuir objetivos a serem alcançados fora do âmbito jurídico. Segundo Cândido Rangel Dinamarco:

Por isso é que, hoje, todo estudo teleológico da jurisdição e do sistema processual há de extrapolar os lindes do direito e da sua vida, projetando-se para fora. É preciso, além do objetivo puramente jurídico da jurisdição, encarar também as tarefas que lhe cabem perante a sociedade e perante o Estado como tal. O processualista contemporâneo tem a responsabilidade de

\footnotetext{
${ }^{32}$ DINAMARCO, 2001, p. 177.

${ }^{33}$ COSTA, 2009, p. 116.

${ }^{34} \mathrm{O}$ movimento, sob essa perspectiva, revela a base para a extensão da tutela jurisdicional aos interesses com titularidade indeterminada, admitindo-se no sistema processual a defesa de interesses sob a ótica objetiva, em razão de sua relevância social conforme cristalizada no direito objetivo, sem o tradicional enfoque subjetivo.

35 "Realmente, se o Estado tem como um de seus fundamentos de existência a organização e solução dos conflitos surgidos na sociedade, até porque proíbe a autotutela, a tutela jurisdicional prestada deve ser adequada e efetiva. Caso contrário, o poder estatal perde uma de suas razões de ser. É nesse contexto de publicização do processo que surgem as noções de instrumentalidade do processo, de processo civil de resultados e efetividade do processo." (COSTA, 2009, p. 117).
} 
conscientizar esses três planos, recusando-se a permanecer num só, sob pena de esterilidade nas suas construções, timidez ou endereçamento destoante das diretrizes do próprio Estado social ${ }^{36}$.

Assim é que Cândido Rangel Dinamarco, em minucioso estudo a respeito da instrumentalidade do processo, sistematiza os escopos da jurisdição em escopos sociais e políticos, além daquele jurídico, visto sob o entendimento de Giuseppe Chiovenda como a atuação concreta da lei, ou de acordo com a doutrina de Francesco Carnelutti, a justa composição da lide.

São escopos sociais a promoção da pacificação social com justiça e da educação. A pacificação é objetivo compartilhado entre os planos material e processual do ordenamento. Os conflitos de interesse ${ }^{37}$ geram insatisfações, que por causarem risco de desagregação social, devem ser eliminadas pelo Estado. Não se trata, obviamente, de qualquer forma de pacificação no sentido de se impor uma decisão inafastável e imutável, pondo fim a um conflito, devendo, além disso, se fazer com bases em critérios justos. ${ }^{38} \mathrm{~A}$ educação diz respeito ao efeito de esclarecer a população a respeito de seus direitos e obrigações, aumentando o nível de confiança da sociedade no Poder Judiciário, e criando a consciência de que o processo pode representar a solução para muitos problemas, de modo a incentivar os sujeitos a usufruírem do serviço jurisdicional, proporclionando, via reflexa, condições para a satisfação do escopo maior da pacificação social.

São três os escopos políticos que se relacionam com um trio de valores fundamentais no Estado Democrático de Direito, a saber: o poder, a liberdade e a participação. Serve o processo como meio para o Estado afirmar o seu poder e a autoridade de suas decisões, impondo-as aos jurisdicionados de forma definitiva e assim preservando o seu ordenamento jurídico-substancial. Fica mais evidente esse objetivo ao se considerar o conjunto dos processos dirimidos pelo Estado e não cada caso individual tomado isoladamente. No que diz respeito à liberdade, serve o processo como meio para limitar o

\footnotetext{
${ }^{36}$ DINAMARCO, 2001, p. 153.

${ }^{37}$ Cândido Rangel Dinamarco expressamente não se filia à noção de conflito conforme o conflito de interesses da teoria de Francesco Carnelutti, repudiando o método com foco na lide. Conflito, para Dinamarco derivaria de insatisfações causadas por condutas contrarias a um seu interesse, inclusive em razão da limitação dos bens sobre os quais os inúmeros interesses recaem. Conflitos sob esse entendimento se encontrariam em todos e quaisquer processos, e não apenas nos processos civil cognitivos de natureza condenatória e constitutiva (DINAMARCO, 2001, pp. 160/161).

${ }^{38}$ DINAMARCO, 2001, p. 161.
} 
exercício do poder do Estado, impedindo-o de indevidamente invadir a esfera de liberdade individual dos sujeitos, com violação do devido processo legal e demais direitos e garantias constitucionais e legais. No que toca à participação, também se presta o processo como veículo de participação democrática, como, por exemplo, no caso da ação popular e de outras demandas coletivas. Trata-se do exercício da democracia na medida em que provoca uma influência sobre os centros de poder ${ }^{39}$.

A concepção do processo voltado apenas ao seu escopo jurídico deu a ele feições eminentemente individualistas. Tendo por base o direito subjetivo e o conflito individual entre sujeitos, não contemplava um mecanismo de resolução de conflitos metaindividuais. ${ }^{40}$ A esse respeito, duas mudanças se revelaram transformadoras do sistema. Em primeiro lugar, o reconhecimento jurídico dos interesses metaindividuais, hoje genericamente realizado no país em nível infraconstitucional por meio do Código de Defesa do Consumidor, em razão do qual aludidos interesses passaram a ser concebidos como direitos $^{41}$. Em segundo lugar, a ampliação dos escopos do processo, especialmente no que diz respeito à promoção da paz social, revelou que o processo, conforme concebido, excluía os conflitos que não fossem individuais, ficando estes à margem do sistema, criando assim, um permanente estado de tensão entre interesses afetando coletividades ${ }^{42}$.

\footnotetext{
${ }^{3939}$ DINAMARCO, 2001, p. 171.

40 A posição central ocupada pela noção de direito subjetivo, aliada à tradicional ligação com seu titular determinado, são razões identificadas por Kazuo Watanabe para que os interesses metaindividuais não fossem juridicamente protegidos. Segundo o autor: "A necessidade de estar o direito subjetivo sempre referido a um titular determinado ou ao menos determinável impediu por muito tempo que os 'interesses' pertinentes, a um tempo, a toda a coletividade e a cada um dos membros dessa mesma coletividade, como, por exemplo, os 'interesses' relacionados ao meio ambiente, à saúde, à educação, à qualidade de vida etc., pudessem ser havidos por juridicamente protegíveis. (...) Hoje, com a concepção mais larga de direito subjetivo, abrangente do que outrora se tinha como mero 'interesse' na ótica individualista então predominante, ampliou-se o espectro de tutela jurídica e jurisdicional." (WATANABE, 2011, p. 70).

${ }^{41}$ Conforme aponta Ada Pellegrini Grinover: "não bastava reconhecer os direitos de solidariedade. Era preciso que o sistema jurídico os tutelasse adequadamente, assegurando sua efetiva fruição. Da declaração dos novos direitos era necessário passar à sua tutela efetiva, a fim de se assegurarem concretamente as novas conquistas da cidadania. E, como cabe ao direito processual atuar praticamente os direitos ameaçados ou violados, a renovação fez-se sobretudo no plano do processo." (GRINOVER, 2011, p. 41).

42 "A concentração das atenções sobre o objetivo jurídico do sistema processual, ou seja, sobre o seu caráter instrumental ao direito material objetivo (deixando na sombra a relevância social e política do processo) é, por outro lado, responsável pelo imobilismo do sistema, que nasceu sob o signo do individualismo e ao longo de dois milênios continua até hoje aferrado a técnicas individualistas incompatíveis com o palpitar solidarista dos tempos. Tem-se, com isso, na marca da formação do processo, a regra da legitimidade ad causam individual, só excepcionada em casos raros, de direito estrito; no ponto de terminação do processo de conhecimento, a eficácia direta da sentença de mérito atingindo somente as partes do processo e a autoridade da coisa julgada subjetivamente limitada a elas. E têm-se, ao longo de todo o arco dos diferentes procedimentos, critérios e disposições que pressupõem o envolvimento de indivíduos e não de categorias. São reflexos não só desse modo estritamente jurídico de ver a ordem processual instrumentalmente conexa à substancial, como também da tradicional interpretação individualista dessa própria instrumentalidade; sua interpretação evolutiva, associada à abertura do leque dos escopos do processo na área social e na política,
} 
O instrumentalismo trouxe para legislador, o estudioso e o aplicador do direito preocupações no sentido de tornar o processo apto a alcançar os escopos a ele imputados. Fala-se, nesse sentido, na efetividade do processo para se referir ao cumprimento de toda sua "função sócio-político-jurídica", atingindo todos os seus escopos. ${ }^{43}$ Além de investigar os caminhos que possam ser trilhados para tornar o processo efetivo no que toca a mecanismos e institutos isoladamente considerados, esforços foram dispensados para se identificar os grandes pontos ou aspectos a serem enfrentados para a efetividade geral do processo.

José Carlos Barbosa Moreira, a esse respeito, afirma que a efetividade se proporciona por meio de um programa básico com cinco tópicos: (i) a disponibilização de instrumentos processuais de tutela adequados a todos os direitos e posições jurídicas de vantagem; (ii) a possibilidade prática de uso de aludidos instrumentos (viabilidade), independentemente de quem seja o titular ou os titulares do direito ou posição jurídica de vantagem em questão, mesmo que componham grupo indeterminável de sujeitos; (iii) condições para a integral reconstituição dos fatos relevantes da causa, de forma a que o convencimento do juiz possa se aproximar ao máximo da realidade; (iv) capacidade do processo resultar no efetivo gozo do direito pelo seu titular nos termos especificados no ordenamento; e (v) obtenção de resultados com o mínimo dispêndio de tempo e energias ${ }^{44}$.

Cândido Rangel Dinamarco alude a quatro aspectos fundamentais, reconhecendo que por vezes podem vir a se contrapor já que algumas medidas, muito embora atendam algum dos escopos, não estarão em plena conformidade com outros. São eles: (i) admissão em juízo busca da universalidade da tutela jurisdicional de modo a eliminar os óbices ao ingresso na Justiça, sejam eles jurídicos (legitimidade ativa individual), econômicos (pobreza e custos do processo) ou sociais (desinformação e descrença); ${ }^{45}$ (ii) o modo de ser do processo - no

\footnotetext{
são fatores capazes de contribuir eficazmente para a correção desses rumos e correta teorização das novas tendências". (DINAMARCO, 2001, pp. 222/223).

43 "Para a efetividade do processo, entendida como se propõe, significa a sua almejada aptidão a eliminar insatisfações, com justiça e fazendo cumprir o direito, além de valer como meio de educação geral para o exercício e respeito aos direitos e canal de participação dos indivíduos nos destinos da sociedade e assegurarles a liberdade. Sempre, como se vê, é a visão dos objetivos que vem a iluminar os conceitos e oferecer condições para o aperfeiçoamento do sistema." (DINAMARCO, 2001, p. 271).

${ }^{44}$ MOREIRA, Barbosa. Notas sobre o Problema da "Efetividade do Processo". in Temas de Direito Processual: terceira série. 1. ed. Saraiva: São Paulo, 1984. pp 27/42.

${ }^{45}$ DINAMARCO, 2001, pp. 274/283.
} 
que toca ao exercício das garantias constitucionais da ação e da defesa, especialmente quanto ao contraditório, inquisitividade, prova e procedimento, porquanto a forma de tratamento desses itens repercutirá na efetividade da tutela resultante do processo; ${ }^{46}$ (iii) a justiça das decisões - não basta o provimento de uma decisão efetiva, sendo necessário que seja justa, extraindo-se o valor da norma legislada com apoio dos valores sociais correntes e as mutações axiológicas da sociedade $;^{47}$ e (iv) a efetividade das decisões - provimento de decisões que sejam capazes de propiciar a mais ampla tutela dos direitos reconhecidos, inclusive no que toca a sua tempestividade ${ }^{48}$.

Tratando do correlato tema do acesso à justiça, Mauro Cappelletti e Bryant Garth aludem a uma mudança do significado dado à expressão. No passado, representava um direito natural que seria observado na medida em que o Estado não permitisse que outros o violassem, não exigindo qualquer outra postura por parte do Poder Público. Não se dava atenção a problemas práticos que se apresentavam rotineiramente, como a diferença entre os potenciais litigantes ou a insuficiência de recursos de parcela da população para fazer frente aos custos do processo, concentrando-se as preocupações no caráter formal, teórico e conceitual dos institutos. Com a consagração dos direitos fundamentais de caráter social no século XX, reconheceu-se a necessidade da postura ativa do Estado para a sua implementação. Nesse contexto, passou o direito ao acesso efetivo a ser considerado de máxima importância, sem o qual os demais direitos individuais e sociais ficariam destituídos de sentido em razão da ausência de um mecanismo para que pudessem ser reclamados. ${ }^{49} \mathrm{O}$ acesso passou a ser visto como a forma pela qual os direitos se tornam efetivos, definindo-se pela consideração dos institutos processuais na realidade política, social, econômica e psicológica em que se inserem. Fundamental, para tanto, foi a percepção de que o processo civil se relaciona com a ordem substancial em que se insere, não se encontrando no vácuo abstrato conceitual.

\footnotetext{
${ }^{46}$ DINAMARCO, 2001, pp. 283/293.

${ }^{47}$ DINAMARCO, 2001, pp. 293/297.

${ }^{48}$ DINAMARCO, 2001, pp. 297/303.

49 "O acesso à justiça pode, portanto, ser encarado como o requisito fundamental — o mais básico dos direitos humanos — de um sistema jurídico moderno e igualitário que pretenda garantir, e não apenas proclamar os direitos de todos." (CAPPELLETTI, Mauro; GARTH, Bryant. Acesso à justiça. Tradução de Ellen Gracie Northfleet. Porto Alegre: Sergio Fabris, 1988, p. 12)
} 
De acordo com estudos de Mauro Cappelletti e Bryant Garth, são pelo menos de três ordens os óbices ao acesso à justiça. Os econômicos referem-se aos custos do processo e à baixa capacidade econômica de parte dos jurisdicionados para arcar com esses valores, muitas vezes deixando seus conflitos sem resolução. Muito embora possa haver a previsão de que o sucumbente arcará com as custas, despesas e honorários advocatícios ao final do processo, a questão ainda será relevante pela incerteza do sucesso e a demora para que o feito atinja o seu fim. Em causas de pequeno valor a questão assume ainda maior relevância, haja a vista a possibilidade dos custos superarem o potencial e incerto proveito a ser obtido.

Os jurídicos implicam restrições decorrentes da configuração dos institutos e mecanismos jurídicos, inclusive no que toca aos contornos tradicionalmente atribuídos à legitimidade. O foco dessa preocupação se refere aos interesses difusos, com relação aos quais se nega aos interessados individuais a legitimidade para agirem em sua defesa, ou o seu benefício pessoal é tão insignificante que ficam desencorajados a agir nesse sentido ${ }^{50}$.

Os sociais pertinem ao descrédito do Poder Judiciário disseminado na população, associado com desigualdades entre os potenciais litigantes, muitos dos quais ressentidos de falta de informação a respeito do Direito e do universo jurídico, levando à sua baixa capacidade jurídica ${ }^{51}$.

Nota-se, assim, que em todas essas análises instrumentalistas destaca-se como um dos elementos da efetividade do processo a abertura do sistema para demandas em que se busque tutelar interesses metaindividuais, dentre outros excluídos do sistema, dispensandose a elas tratamento adequado às particularidades do conteúdo que veiculam ${ }^{52}$.

\footnotetext{
50 "A concepção tradicional do processo civil não deixava espaço para a proteção dos direitos difusos. O processo era visto apenas como um assunto entre duas partes, que se destinava à solução de uma controvérsia entre essas mesmas partes a respeito de seus próprios interesses individuais. Direitos que pertencessem a um grupo, ao público em geral ou a um segmento do público não se enquadravam bem nesse esquema. As regras determinantes da legitimidade, as normas de procedimento e a atuação dos juízes não eram destinadas a facilitar as demandas por interesses difusos intentadas por particulares." (CAPPELLETTI, 1988, pp. 49/50).

${ }^{51}$ COSTA, 2009, p. 130. CAPPELLETTI, 1988, pp. 49/50.

52 A segunda onda renovatória do processo civil proposta por Mauro Cappelletti e Bryant Garth refere-se justamente à preocupação do ingresso dos interesses metaindividuais no sistema processual, enquanto a primeira disse respeito à assistência dos necessitados e a terceira, a diferentes aspectos a respeito do modo de ser do processo.
} 
A questão não se resume ao aumento do número de demandas que ingressam no sistema judicial, representando o aumento de amplitude dos casos de forma a ensejar a abertura do Judiciário para todas as classes sociais e as espécies de conflitos. A efetivação do acesso à justiça significa, também, a ampliação dos interesses sujeitos à apreciação do Poder Judiciário.

Não basta que o acesso desses interesses ao sistema se dê apenas formalmente, com a previsão constitucional do direito de ação sob a perspectiva de garantia à via judicial contra eventuais óbices criados para dificultar o ingresso na Justiça. Mais do que se exigir a abstenção da criação de obstáculos, requer-se uma postura pró-ativa para eliminar os óbices existentes, inclusive por meio da criação e adaptação de mecanismos processuais adequados e efetivos para a resolução do amplo espectro de conflitos que despontam na sociedade contemporânea ${ }^{53}$.

Os conflitos que de outra forma ficavam excluídos do sistema processual, perpetuando insatisfações e levando à crise de legitimidade da ordem jurídica e do próprio Estado, caracterizavam uma litigiosidade contida, expressão cunhada por Kazuo Watanabe. ${ }^{54}$ Esse fenômeno consistia uma das causas para a proliferação de atos de violência na sociedade, como reação ao sentimento de impotência em face de constantes violações a interesses de que se julga legitimamente titular.

Ressalte-se que o acesso à justiça não se resume à possibilidade de apresentar uma demanda em juízo. Mais do que isso, significa o acesso à ordem jurídica justa ${ }^{55}$ no sentido

\footnotetext{
${ }^{53}$ COSTA, 2009, p. 128.

54 "Aumentam-se, assim, os conflitos não solucionados através desses mecanismos pacíficos e normais. Esses conflitos podem ser distribuídos, a grosso modo, em dois grupos: 1) os conflitos que são canalizados para o Judiciário para a solução estatal e autoritativa; 2) os conflitos que ficam completamente sem solução, muitas vezes até pela renúncia total do direito pelo prejudicado. É o que podemos denominar de 'litigiosidade contida', fenômeno extremamente perigoso para a estabilidade social, pois é um ingrediente a mais na 'panela de pressão' social, que já está demonstrando sinais de deteriorização do seu sistema de resistência" (WATANABE, Kazuo. Filosofia e Características Básicas do Juizado Especial de Pequenas Causas. In WATANABE, Kazuo (Coord.). Juizado Especial de Pequenas Causas: Lei 7.244, de 7 de novembro de 1984. São Paulo: Revista dos Tribunais, 1985).

55 "A problemática do acesso à Justiça não pode ser estudada nos acanhados limites do acesso aos órgãos judiciais já existentes. Não se trata apenas de possibilitar o acesso à Justiça enquanto instituição estatal, e sim de viabilizar o acesso à ordem jurídica justa. (...)

Em conclusão:

a) o direito de acesso à Justiça é, fundamentalmente, direito de acesso à ordem jurídica justa;

b) são dados elementares desse direito: (1) o direito à informação e perfeito conhecimento do direito substancial e à organização de pesquisa permanente a cargo de especialistas e orientada à aferição constante da adequação entre a ordem jurídica e a realidade sócio-econômica do País; (2) direito de acesso à Justiça
} 
de obtenção de justiça substancial, inclusive no que toca à qualidade, a tempestividade e a efetividade da tutela concedida ${ }^{56}$.

\subsection{PROCESSOS COLETIVOS PARA A TUTELA DE INTERESSES DIFUSOS E COLETIVOS}

Como principal veículo de ingresso dos interesses metaindividuais no sistema processual, buscando transpor os óbices que levavam à exclusão destes, foram introduzidas no ordenamento como instrumentos processuais as ações coletivas.

A institucionalização das ações coletivas trouxe impactos profundos no sistema jurisdicional brasileiro, demandando a revisão de institutos processuais e alterando a concepção do exercício do poder jurisdicional, com a diversificação das funções judiciais. Os instrumentos e a função de dirimir conflitos individuais entre partes que participam da relação processual não se adequavam para a resolução de conflitos envolvendo interesses transindividuais fluídos na sociedade ou pertinentes a certos grupos ou classes, com repercussão política e sem a participação de todos os afetados ${ }^{57}$.

Foi a Lei 7.347/85 - a Lei da Ação Civil Pública - o instrumento introdutório da defesa judicial de interesses difusos e coletivos no país ${ }^{58}$. Por mais que a Lei 6.938/81 já permitisse a defesa de interesses difusos ambientais pelo Ministério Público, não previa mecanismos processuais adequados para tanto ${ }^{59}$. Na redação original da lei de 1985, não se

adequadamente organizada e formada por juízes inseridos na realidade social e comprometidos com o objetivo de realização da ordem jurídica justa; (3) direito à preordenação dos instrumentos processuais capazes de promover a efetiva tutela de direitos; (4) direito à remoção de todos os obstáculos que se anteponham ao acesso efetivo à Justiça com tais características" (WATANABE, Kazuo. Acesso à Justiça e Sociedade Moderna. In: DINAMARCO, Cândido Rangel; GRINOVER, Ada Pellegrini; WATANABE, Kazuo (Coord.). Participação e Processo. São Paulo: Editora Revista dos Tribunais, 1988, pp. 128/135).

${ }^{56}$ DIANAMARCO, 2005, p. 133.

${ }^{57}$ SALLES, 2000, p. 47/48.

58 "Os instrumentos de direito processual, existentes no ordenamento jurídico vigente até então, não permitem a tutela desses novos interesses, pois se esgotavam no modelo tradicional de solução individualizada de litígios. Algumas respostas pontuais foram surgindo, com a já citada edição da Lei de Ação Popular ou mesmo a legitimação do Ministério Público para a defesa de alguns interesses ambientais (Lei n 6938/81)." (COSTA, 2009, p. 156). Lembra Ada Pellegrini Grinover que, com base em mudança legislativa de 1977 que havia incluído no objeto da ação popular, como patrimônio público, bens e direitos com valor artístico, estético, histórico ou turístico, ações populares foram manejadas em busca da tutela de interesses difusos relacionados ao meio ambiente, mas ficavam restritas a violações decorrentes a ações ou inações do Estado, na medida em que tal mecanismo processual não era cabível com relação à conduta de particulares. (GRINOVER, 2011, pp. 41/42).

${ }^{59}$ SALLES, 2000, p. 47. 
admitia aludida ação como mecanismo de tutela geral de interesses metaindividuais, mas apenas daqueles ligados ao meio ambiente e ao consumidor. Com a Constituição da República de 1988, a tutela coletiva desses interesses que superavam a esfera individual tornou-se universalizada, sem limitações quanto ao objeto ${ }^{60}$. Por fim, com o Código de Defesa do Consumidor, ampliou-se o campo de incidência da Lei da Ação Civil Pública, conceituando-se os interesses difusos e coletivos em termos gerais e prevendo a tutela coletiva de interesses individuais marcados pela homogeneidade ${ }^{61}$.

No último quarto de século, com o reconhecimento e a proteção de novos direitos de caráter metaindividual, tais como os de índole ambiental e consumerista, em conjunto com o fenômeno da sociedade de massa, percebeu-se que o processo civil tradicional não dispunha de instrumental apropriado à proteção de interesses que não fossem de titularidade individual ou ainda contra atos ilícitos que não produzissem impacto relevante para os sujeitos individualmente considerados, mas cujos efeitos, se tomados na esfera coletiva, fossem significativos.

Assim é que a efetividade do reconhecimento jurídico dos interesses coletivos, supra ou metaindividuais, em conformidade com as características a eles peculiares, dependeu da criação ou do aperfeiçoamento de princípios e institutos processuais que tornassem o processo um mecanismo adequado a se manejar e tutelar esses interesses. ${ }^{62}$

Em termos práticos, um dos principais pontos distintivos dessa categoria de interesses, no que diz respeito à sua tutela em juízo, refere-se à inviabilidade da participação direta de todos os seus titulares no processo ${ }^{63}$. Diversos são os fatores que contribuem para isso.

${ }^{60}$ A Constituição de 1988 trouxe diversos dispositivos enaltecendo a proteção dos interesses coletivos. Ada Pellegrini Grinover aponta a função atribuída ao Ministério Público para defender todos os direitos difusos e coletivos, admitindo a ampliação da legitimação ativa por lei; a previsão da representação pelas associações dos seus associados; a criação do mandado de segurança coletivo; a legitimação dos sindicatos para a defesa dos interesses coletivos e individuais da categoria; e a legitimação dos índios e seus agrupamentos para a defesa dos interesses e direitos que lhes tocam. (GRINOVER, 2011, p. 42).

${ }^{61}$ Trata-se dos interesses individuais homogêneos, examinados abaixo.

62 "O processo coletivo, como vertente metodológica do instrumentalismo substancial, permite a adequação de conceitos e institutos do direito processual. Aproveita-se o trabalho já elaborado, modernizando-o às exigências da atualidade e dos conflitos coletivos." (LEONEL, Ricardo de Barros. Manual do Processo Coletivo. 2. ed., São Paulo: RT, 2011, p. 145).

${ }^{63}$ Tratando daqueles interesses essencialmente coletivos, já lecionava José Carlos Barbosa Moreira: "É que se revela aqui impraticável a solução 'normal', consistente em fazer coincidir a legitimatio ad causam com a titularidade da relação jurídica litigiosa: há uma pluralidade de titulares, em regra numerosos e indeterminados, ou mesmo indetermináveis, ao menos para fins práticos. Cumpre portanto afastar in limine, por motivos óbvios, a eventualidade de atribuir-se a legitimação, em conjunto, à totalidade dos co-titulares, 
Muitas vezes sequer é possível determinar quem são todos os sujeitos que compõem a coletividade em questão. Essa impossibilidade de determinação é justamente uma característica dos interesses difusos. Em outros casos, por mais que seja possível tal determinação, o número e a dispersão dos interessados podem ser tão significativos e o valor patrimonial do interesse em questão, ao ser considerado individualmente, pode ser tão inexpressivo que chegam ao ponto de desencorajar qualquer iniciativa de salvaguarda conjunta do interesse comum. Mesmo que superados tais óbices, a participação de muitos sujeitos em um dos polos do processo, cada qual com seus interesses particulares, que, no mais das vezes, pretenderiam ver privilegiados, acabaria por tumultuar o feito e prejudicar a tutela daquele interesse notadamente coletivo. Exigir a participação direta de todos os membros dessa coletividade no processo seria, assim, impedir a tutela jurisdicional dos interesses coletivos.

De forma a viabilizar a tutela jurisdicional de interesses coletivos admitiu-se que, no ajuizamento de demandas judiciais tidas por coletivas, certos sujeitos pudessem representar a coletividade titular do interesse objeto da causa. A definição daqueles que poderiam desempenhar tal papel resultou de uma opção do legislador. Por vezes aceita-se que seja um membro da coletividade afetada ${ }^{64}$, como pode ocorrer na ação popular, em outros casos, que sejam certos terceiros que, sob determinados critérios, assumam a atribuição de promover a defesa judicial de tal interesse, como o Ministério Público nas ações civis públicas. O representante agirá em nome próprio para a defesa de interesse que não lhe pertence, caracterizando, assim, hipótese de legitimidade extraordinária ou substituição processual, ressaltando-se a existência de divergência doutrinária a respeito de tal classificação.

isto é, de situar o caso na área do litisconsórcio ativo necessário" (BARBOSA MOREIRA, José Carlos. Tutela Jurisdicional dos Interesses Coletivos ou Difusos. In: Temas de Direito Processual: terceira série. 1. ed. Saraiva: São Paulo, 1984, p. 198).

${ }^{64}$ José Carlos Barbosa Moreira (BARBOSA MOREIRA, 1984) acenava para a possibilidade do direito processual brasileiro assimilar a legitimidade concorrente e disjuntiva dos interessados individuais, vez que "Não constitui fenômeno pouco familiar a esta [sistemática do direito brasileiro], com efeito, reclamar uma pessoa em juízo a satisfação que seja, ao mesmo tempo, 'próprio' e 'alheio'." (BARBOSA MOREIRA, José Carlos. A Legitimação para a Defesa dos "Interesses Difusos" no Direito Brasileiro. In: Temas de Direito Processual: terceira série. 1. ed. Saraiva: São Paulo, 1984, p. 189). A dificuldade que despontaria nesse caso, por vezes, seria a de identificar um verdadeiro direito subjetivo que pudesse vir a ser pleiteado por seu titular individual de forma a também tutelar um direito coletivo coincidente. 
Nessas ações coletivas, conforme nota Ada Pellegrini Grinover ${ }^{65}$, permite-se a maior participação da coletividade pelo processo, por mais que essa participação seja menor no processo, servindo como um instrumento de acesso à justiça por trazerem ao Poder Judiciário casos em que estaria incubada litigiosidade contida.

Fato é que desse processo em que a coletividade se faz representada podem resultar decisões que de alguma forma afetem pessoas que sequer tiveram conhecimento da demanda. Daí porque diversos institutos processuais empregados no processo tradicional apresentam diferenças ao serem aplicados às ações coletivas.

Tratando-se de processos referentes a interesses difusos ou coletivos em sentido estrito é natural que as decisões de mérito afetem toda a coletividade em questão. Isso porque é característica desses interesses sua indivisibilidade, de forma que uma violação atinja todos os membros do grupo, do mesmo modo que sua tutela a todos aproveita. ${ }^{66}$ Sua formação não decorre da mera justaposição de interesses individuais, que poderia vir a ser subjetivamente desmembrada possibilitando que cada uma das partes recebesse tratamento distinto. Os interesses difusos e coletivos em sentido estrito são interesses essencialmente coletivos e não subsistem sem a coletividade a que pertencem. Por possuírem essa natureza coletiva indivisível o tratamento processual adequado a lhes ser dispensado é o coletivo.

A abertura do Judiciário para a tutela de interesses transindividuais, para Carlos Alberto de Salles, representou o surgimento de um processo civil de interesse público. O direito processual regula o exercício do poder jurisdicional pelo Estado e, portanto, tem natureza eminentemente pública, nada obstante possa ser empregado para dirimir controvérsias privadas entre sujeitos singulares. Volta-se o sistema processual à consecução de valores e objetivos maiores do sistema, como a eliminação de conflitos de interesses, conforme apregoa Francesco Carnelutti, ou a aplicação do direito material, segundo doutrina de Giuseppe Chiovenda. Não é essa, entretanto, a razão para configurar-se um processo civil

\footnotetext{
${ }^{65}$ GRINOVER, 2011, p. 28.

${ }^{66}$ De acordo com José Carlos Barbosa Moreira: "Em muitos casos, o interesse em jogo, comum a uma pluralidade indeterminada (e praticamente indeterminável) de pessoas, não comporta decomposição num feixe de interesses individuais que se justapusessem como entidades singulares, embora análogas. Há, por assim dizer, uma comunhão indivisível de que participam todos os possíveis interessados, sem que se possa discernir, sequer idealmente, onde acaba a 'quota' de um e onde começa a de outro. Por isso mesmo, instaurase entre os destinos dos interessados tão firme união, que a satisfação de um só implica de modo necessário a satisfação de todos; e, reciprocamente, a lesão de um só constitui, ipso facto, lesão da inteira coletividade." (BARBOSA MOREIRA, 1984, p. 195).
} 
de interesse público, mas sim que os interesses manejados nos processos coletivos dizem respeito ao interesse público ${ }^{67}$.

A defesa judicial dos interesses difusos e coletivos representa a atribuição ao Judiciário da função de adjudicar o interesse público na situação concreta trazida pelas partes. Dentre os interesses protegidos em consonância com os valores e objetivos traçados no ordenamento a partir da Constituição, torna-se sua incumbência indicar aqueles preponderantes, cotejando objetivos sociais contrapostos. E ao dessa forma agir, não raro decide a respeito da alocação e apropriação de bens e recursos comuns, deixando de realizar justiça meramente retributiva para perfazer justiça distributiva, dando destinação individual ou coletiva certa para tais bens e recursos ${ }^{68}$.

Nessa seara, a matéria submetida ao juiz dirá respeito a valores constitucionais e outras regras jurídicas de índole infra-constitucional que lhes dão concretude, relacionando-se às políticas públicas definidas ou que tais regras deveriam definir. Tradicionalmente, a definição do interesse publico se dava exclusivamente no âmbito do Legislativo e, dentro dos parâmetros por este fixados, do Executivo ${ }^{69}$.

A utilização do Judiciário como palco para a tutela dos interesses metaindividuais não foi isenta de críticas, especialmente de cunho político. Representaria uma forma de "pulverização" do poder estatal, reconhecendo-se nos grupos intermediários portadores de interesses metaindividuais legitimidade para persegui-los, concorrendo com o poder político centralizador do Estado. Importaria, também, uma forma de burlar o sistema político-representativo, contornando as instâncias estatais com atribuição de extrair e normatizar as matérias de interesse social. O fenômeno é o mesmo que levou a doutrina administrativista a identificar a multiplicação do interesse público. Aludidos grupos, todavia, passaram a ser considerados canais legítimos de comunicação para interesses metaindividuais de outra forma marginalizados pelo Poder Público e pelo poder econômico. A participação e a colaboração dos grupos e do indivíduo no processo decisório estatal são admitidas como práticas democráticas legitimadoras da decisão

\footnotetext{
${ }^{67}$ Para esse fim, esclarece, com base no uso corrente da doutrina norte-americana, ter como interesse público o interesse pertencente a uma generalidade de pessoas, em oposição a interesses particulares, e não em oposição a interesses privados.

${ }^{68}$ SALLES, 2000, pp. 49/50.

${ }^{69}$ SALLES, 2000, p. 52.
} 
tomada. $^{70}$ Trata-se da aplicação da diretriz da democracia participativa, que alberga a participação dos grupos sociais não só no desempenho do Estado das funções legislativas e administrativas, como também jurisdicionais ${ }^{71}$.

Ademais, também se aponta para o risco do superdimensionamento do Poder Judiciário, levando ao desequilíbrio do balanceamento ínsito ao sistema de repartição de Poderes. Isso porque na apreciação desses conflitos, nos mais das vezes do juiz se exigiria mais do que uma mera atividade substitutiva da vontade das partes por meio da aplicação do direito objetivo legislado, fazendo-se necessária a ponderação de interesses socialmente relevantes contrapostos, decidindo como se compõem no caso concreto, o que constituiria matéria de decisão política de atribuição dos outros Poderes.

A abertura do Judiciário para essas matérias, contudo, resulta da incapacidade dos demais de tratarem desses interesses coletivos, marcando o seu papel subsidiário. Conforme nota Rodolfo Camargo Mancuso constitui um "sinal de que os outros não estão a tutelar esses interesses, obrigando os cidadãos (através da ação popular, v.g.) ou as associações e o Ministério Público (através da ação civil pública) a recorrerem diretamente à via jurisdicional". ${ }^{72}$ Também constitui um instrumento de participação democrática pois disponibiliza o processo decisório a todos os legitimados, não se impondo os mesmos óbices que vigoram para o acesso eficaz dos indivíduos às instâncias decisórias legislativa e administrativa. ${ }^{73}$ Ademais, não age o Poder Judiciário sponte propria ou decidindo a respeito de toda e qualquer matéria que lhe pareça relevante, configurando a jurisdição um poder inerte, em razão do que só é exercitado mediante provocação, por aplicação do princípio da demanda, nos limites em que formulado o pedido e dentro dos contornos do objeto do processo.

Não se defende que seja o Judiciário o foro exclusivo de defesa dos interesses coletivos, sendo certo que todos os outros Poderes devem ser exercitados contemplando instrumentos de democracia participativa, permitindo o influxo das reinvindicações dos grupos de interesse e fomentando o debate com os setores pertinentes da sociedade civil. ${ }^{74}$ Aliás, em

\footnotetext{
${ }^{70}$ MANCUSO, 2004, p. 129.

${ }^{71}$ MANCUSO, 2004, p. 134.

${ }^{72}$ MANCUSO, 2004, p. 137.

${ }^{73}$ MANCUSO, 2004, p. 136.

${ }^{74}$ MANCUSO 2004, p. 139.
} 
sede legislativa e administrativa, aludidos processos de exercício de poder recebem possibilidades mais abertas de participação e discussões, sem as restrições e o formalismo atinentes ao processo judicial. ${ }^{75}$ Mesmo nos casos em que as soluções são determinadas nessas outras esferas do Poder estatal, pode o Judiciário vir a representar relevante papel para assegurar interesses subrepresentados ou direitos fundamentais de minorias que por não possuírem peso político ou força econômica não são devidamente considerados no processo político pelos poderes majoritários, ou na dinâmica de mercado pelos agentes econômicos.

Recorde-se que os Poderes Legislativo e Executivo, em razão de seu caráter majoritário, ficam mais suscetíveis aos fenômenos da captura e cooptação, sofrendo influências indevidas de interesses privados com trâmite nos bastidores do Poder, bem assim pressões das maiorias em detrimento de interesses sub-representados na sociedade, nada obstante sejam eles relacionados a valores maiores no sistema jurídico e político.

Considerando os diferentes processos decisórios disponíveis, sobretudo em função da instituição a eles atrelada, revela-se o Poder Judiciário foro preferencial, em contraste com o mercado e o político. Não como instituição e processo aprioristicamente mais adequados em todos os casos, mas somente naqueles em que os outros processos foram falhos a considerar os parâmetros básicos da formação do interesse público ${ }^{76}$.

Seja como for, nota-se que as ações coletivas, em suporte ao reconhecimento jurídico dos interesses difusos e coletivos em sentido estrito, formaram a via de acesso dos interesses de coletividades à tutela jurisdicional, provendo o sistema de mecanismos adequados a equacionar os conflitos plurisubjetivos. Nesse sentido, considerando a relação de interdependência entre o direito material e o sistema processual, bem assim a insuficiência da atuação do Estado-administração para garantir a efetividade de aludidos interesses transformados em direitos, representaram as demandas coletivas um mecanismo de coletivização e de tutela de demandas individuais.

\footnotetext{
${ }^{75}$ Em juízo, normalmente as discussões se estabelecem apenas entre autor e réu, admitindo-se em alguns casos a participação de terceiros, nos limites do objeto fixado pelas partes na fase postulatória e caminhando em um sentido apenas, sob um sistema de preclusões. As audiências públicas promovidas pelo Supremo Tribunal Federal em casos de relevância, bem como a admissão dos amicus curiae representam abetura do processo aos influxos da sociedade civil além das partes da relação processual.

${ }^{76}$ SALLES, 2000, pp. 59/60.
} 
Por mais que haja quem entenda que não se confundem com a mera somatória de interesses individuais, lembre-se de que os interesses difusos e coletivos em sentido estrito apresentam uma dimensão pessoal, na medida em que encontram suporte nas necessidades dos membros dos agrupamentos formados pelos seus titulares, ainda que seja impossível determinar quem são esses sujeitos. A tutela coletiva desses interesses, por iniciativa de uma ação coletiva, importa a satisfação das necessidades de todos. Deste modo, uma ação coletiva encerra demandas de todos os membros da coletividade referentes ao mesmo objeto, constituindo, a esse respeito, um mecanismo de coletivização de demandas.

\subsection{PROCESSOS COLETIVOS PARA A TUTELA DE INTERESSES INDIVIDUAIS HOMOGÊNEOS}

As ações coletivas não se prestam, contudo, apenas à tutela de interesses que se qualifiquem como materialmente coletivos. Disciplinou o Código de Defesa do Consumidor a possibilidade de manejo de demanda coletiva para a proteção de certos interesses individuais qualificados ${ }^{77}$.

Aludidos interesses, legalmente denominados interesses individuais homogêneos, são considerados essencialmente individuais e acidentalmente coletivos, conforme lição de José Carlos Barbosa Moreira ${ }^{78}$, ou seja, são individuais na sua essência, mas que admitem tratamento coletivo no campo processual, sendo conjuntamente tuteláveis por meio de uma ação coletiva ${ }^{79}$.

\footnotetext{
${ }^{77}$ José Marcelo Menezes Vigliar aponta ter a Lei 7.913/89 previamente previsto mecanismo de tutela de interesses individuais homogêneos de investidores do mercado de valores imobiliários que tivessem sofrido danos em razão de atos previstos na aludida lei, atribuindo, a legitimidade ativa, entretanto, somente ao Ministério Público (VIGLIAR, José Marcelo Menezes. Interesses Individuais Homogêneos e Seus Aspectos Polêmicos. 2. ed. rev. e atual., São Paulo: Saraiva, 2008, p. 11).

${ }^{78}$ Para Sérgio Cruz Arenhart "são exatamente os mesmos interesses individuais clássicos, apenas com coloração processual distinta. Sempre que os interesses individuais puderem, com utilidade, ser reunidos e decididos de uma só vez, porque comuns os pontos de fato e de direito em que se sustentam, poderão ser caracterizados como interesses individuais homogêneos merecendo sujeitar-se à tutela coletiva" (ARENHART, 2013, p. 43).

${ }^{79}$ Vigliar afirma não se tratar de processo individual com cúmulo subjetivo de demandas por meio de litisconsórcio ativo, mas ação coletiva com o emprego da técnica da substituição processual, veiculando pedido de tutela coletiva (VIGLIAR, 2008, p. 40).
} 
Nas palavras de Kazuo Watanabe, as ações coletivas para a tutela de interesses individuais homogêneos constituem técnica de molecularização dos conflitos que de outra forma receberiam tratamento atomizado ${ }^{80}$.

As características dessa espécie de interesses compreendem: a determinabilidade de seus titulares, sua natureza ou essência individual, a divisibilidade do objeto, e advirem de uma origem comum ${ }^{81}$.

Têm-se como requisitos para o tratamento coletivo de direitos individuais a homogeneidade e a origem comum. ${ }^{82}$ Apesar da lei indicar serem individuais homogêneos aqueles interesses decorrentes de origem comum (artigo 81, parágrafo único, inciso III, do Código de Defesa do Consumidor), entende-se que sua origem não constitui elemento suficiente para caracterizar tal homogeneidade.

A causa comum pode ser fática ou jurídica, também não se exigindo "uma unidade factual e temporal", eis que eventos semelhantes que se repitam no tempo podem constituí-la, como, por exemplo, a mensagem publicitária enganosa veiculada em diferentes meios e em diversas oportunidades. Identificando-se como a causa de lesão geradora de um direito ressarcitório, pode ser a mesma próxima, se dela imediatamente decorrer a lesão, ou remota, se for mediata a sua relação com o dano. ${ }^{83}$ A circunstância de ser próxima ou remota não é capaz, por si só, de desqualificar a tutela coletiva de tais interesses.

A homogeneidade, entretanto, deve ser analisada caso a caso, em razão das circunstâncias que se apresentam. A questão diz respeito à preponderância dos elementos comuns sobre os individuais, ou a "prevalência da dimensão coletiva sobre a individual" ${ }^{84}$. Quanto mais remota for a causa comum, menores as chances de caracterizar-se homogeneidade ${ }^{85}$.

\footnotetext{
${ }^{80}$ WATANABE, 2011, p. 4.

${ }^{81}$ LEONEL, 2011, p. 98.

${ }^{82}$ WATANABE, Kazuo. in GRINOVER, Ada Pellegrini; NERY JUNIOR, Nelson; WATANABE, Kazuo. Código Brasileiro de Defesa do Consumidor: comentado pelos autores do anteprojeto, Vol. II: Processo Coletivo (arts. 81 a 104 e 109 a 119), 10. ed. Rio de Janeiro: Forense, 2011, p. 76.

${ }^{83}$ WATANABE, 2011, p. 76.

${ }^{84}$ No regime da class action for damages norte-americano, que serviu de inspiração para o legislador brasileiro introduzir a tutela coletiva de interesses individuais homogêneos, dentre os requisitos para se admitir o processamento da demanda na forma coletiva, encontram-se: a numerosidade dos membros da classe; a preponderância de questões comuns sobre as peculiares aos indivíduos que formam a classe; e a superioridade do tratamento coletivo pela class action em comparação com outros mecanismos de tutela disponíveis. Aluisio Gonçalves de Castro Mendes defende que aludidos requisitos devam também ser aqui
} 
Presente a heterogeneidade, não se sustenta o tratamento coletivizado, eis que a apuração do direito de cada membro do grupo dependerá do exame de questões que lhe são individuais. A mera diferença na proporção do dano causado, entretanto, não é considerada causa a impedir a tutela coletiva, eis que a condenação na ação coletiva será genérica e a liquidação se faz de forma individual.

Essa forma coletiva de tratamento de interesses individuais que reúnam certas características resulta de uma opção do legislador, uma escolha de índole técnica com o objetivo de (i) ampliar o acesso à justiça, (ii) promover a economia processual; (iii) reduzir o número de processos em trâmite no Judiciário; (iv) evitar decisões conflitantes ou inconsistentes; (v) dar tratamento isonômico a partes nas mesmas condições, concretizando o princípio constitucional da igualdade ${ }^{86}$.

A ampliação do acesso à justiça se faz presente principalmente naqueles casos em que a dimensão dos danos individualmente causados é tão pequena que representa um óbice para a propositura de demanda individual, sobretudo considerando os custos do processo envolvidos ${ }^{87}$.

Nota-se, a esse respeito, que com certa frequência empresas ou outros agentes do mercado, de forma deliberada ou culposa, causam lesão de pequena monta a um número expressivo de indivíduos, mas que, para tais empresas, de forma cumulada, representam ganhos consideráveis. Nessas situações, os incentivos para que os lesados venham a propor ação indenizatória são pequenos. Aqueles que o fizerem, litigarão em desigualdade de armas contra a outra parte, eis que esta se beneficiará de economias de escala decorrentes de sua

observados, sem mencionar a numerosidade. Nas palavras do autor: "A proteção coletiva de direitos individuais deve obedecer, no entanto, aos requisitos da prevalência das questões de direito e de fato comuns sobre as questões de direito ou de fato individuais e da superioridade da tutela coletiva sobre a individual, em termos de justiça e eficácia da sentença; Assemelha-se, assim, ao previsto na legislação norte-americana para as class actions." (MENDES, 2010, p. 226).

${ }^{85}$ WATANABE, 2011, p. 76.

${ }^{86}$ LEONEL, 2011, p. 100. CASTRO, 2009, p. 226

${ }^{87}$ Mesmo com medidas relevantes destinadas a diminuir os custos do processo, como a implantação dos juizados especiais e a assistência jurídica gratuita, não é possível eliminá-los por completo, persistindo custos relacionados, por exemplo, com o tempo do processo e o tempo nele despendido pela parte, privando-a da possibilidade de se dedicar a outros assuntos. 
condição de litigante habitual $^{88}$, bem assim de assessoria jurídica e técnica especializada de que lhe é acessível, além do domínio do conhecimento a respeito da sua área de atuação, que normalmente será pertinente ao objeto do processo. Por fim, mesmo considerando os poucos casos em que o lesado conseguirá ser efetivamente indenizado, o valor consolidados das condenações e dos custos incorridos nos processos serão sensivelmente inferiores aos ganhos advindos da prática ilícita.

Nada obstante eventuais sanções administrativas e penais que aludidas práticas podem vir a ensejar, a tutela coletiva desses interesses individuais lesados representa o aumento do montante indenizatório a que as empresas ficarão obrigadas a pagar em caso de sucumbência, bem assim permitirá, em tese, a defesa mais adequada dos interesses violados pelo representante adequado da coletividade em questão, o qual, supõe-se ter melhores condições de agir nessa condição. Antevendo esse potencial desfecho, os agentes causadores do dano terão maiores incentivos a não adotar a prática lesiva ou a serem mais diligentes de modo a evitá-las. Sob essa perspectiva, serve a demanda como instrumento de efetividade, dando plena realização ao direito material.

Promove-se a economia processual evitando-se o desenvolvimento de processos repetitivos para o tratamento das mesmas questões fáticas e jurídicas, por meio da concentração das demandas em único processo capaz de gerar efeito para todos. Por consequência, previnese a formação de novos processos, contribuindo para o desafogamento do Poder Judiciário de forma a contribuir para a celeridade do julgamento de todos os feitos pendentes.

${ }^{88}$ O litigante habitual acumula experiência nos processos em que litiga, especialmente nos casos de demandas repetitivas, tem melhor trâmite e desenvoltura no foro em razão de sua constante presença, e arca com menores custos por causa, valendo-se de serviços jurídicos mais baratos sem prejuízo de sua defesa técnica já elaborada e aprimorada com o tempo. Nesse sentido, Mauro Cappeletti e Bryant Garth aludem: "As vantagens dos "habituais", de acordo com Galanter, são numerosas:

1) maior experiência com o Direito possibilita-lhes melhor planejamento do litígio;

2) o litigante habitual tem economia de escala, porque tem mais casos;

3) o litigante habitual tem oportunidades de desenvolver relações informais com os membros da instância decisora;

4) ele pode diluir os riscos da demanda por maior número de casos;

5) pode testar estratégias com determinados casos, de modo a garantir expectativa mais favorável em relação a casos futuros. (...)

Parece que, em função dessas vantagens, os litigantes organizacionais são, sem dúvida, mais eficientes que os indivíduos. Ha menos problemas em mobilizar as empresas no sentido de tirarem vantagens de seus direitos, o que, com frequência, se dá exatamente contra aquelas pessoas comuns que, em sua condição de consumidores, por exemplo, são as mais relutantes em buscar o amparo do sistema.

Essa desigualdade relativamente ao acesso pode ser atacada com maior eficiência, segundo Galanter, se os indivíduos encontrarem maneiras de agregar suas causas e desenvolver estratégias de longo prazo, para fazer frente às vantagens das organizações que eles devem amiúde enfrentar. Alguns dos problemas encontrados na implementação dessa estratégia serão abordados a seguir." (CAPPELLETTI; GARTH, 1988, pp. 25/26). 
Ademais, prevenindo a condução de processos paralelos para o tratamento de demanda semelhante, evita-se a prolação de decisões logicamente conflitantes, que são capazes de gerar descrédito no Judiciário e abalo na segurança jurídica ${ }^{89}$.

No atual sistema adotado no país, entretanto, a previsão ou o ajuizamento de uma demanda coletiva tendo por escopo a tutela de interesses individuais homogêneos não tem o condão de impedir que os titulares dos direitos em questão proponham suas demandas individuais $^{90}$

Nota-se que aludido mecanismo atua como "se houvesse a reunião, num único processo, de várias demandas individuais com resultados mais satisfatórios" ${ }^{91}$. Daí porque se pode afirmar se tratar de um mecanismo processual de coletivização de demandas. A tutela unificada não se dá em razão da indivisibilidade do objeto, como ocorre nos interesses coletivos, e sim por motivo de conveniência, revelando-se um instrumento processual mais adequado à situação material a que se refere, dando concretude à instrumentalidade.

\subsection{DEMANDAS COLETIVAS EM ESPÉCIE}

Apesar do destaque que se dá às ações civis públicas, sobretudo em razão do seu emprego mais generalizado e por constituir o instrumento mais característico de defesa de interesses metaindividuais $^{92}$, o rol das demandas coletivas é extenso, por mais que seu objeto potencial seja variado, admitindo-se áreas de sobreposição. Nesse sentido, considera-se

\footnotetext{
${ }^{89}$ Sustenta José Marcelo Menezes Vigliar que os a tutela coletiva desses interesses se dá em prestígio à segurança jurídica, de modo que situações fáticas semelhantes levem a resultados idênticos. O intuito também seria de evitar a repetição de demandas idênticas, com desperdício da atividade jurisdicional. (VIGLIAR, 2008, pp. 24 e 39).

90 A esse respeito, aliás, José Marcelo Menezes Vigliar, notando a possibilidade dos titulares promoverem demandas individuais para a tutela de seus interesses de igual natureza, ainda que marcados pela homogeneidade, afirma inexistir "mecanismo totalmente eficiente para evitar a repetição de demandas". (VIGLIAR, 2008, p. 39).

${ }_{91}^{91}$ LEONEL, 2011, p. 99.

${ }^{92}$ Nada obstante o exposto, não se admite a ação civil pública para veicular todo e qualquer interesse metaindividual. Susana Henriques da Costa afirma, a esse respeito, que ficariam excluídos os interesses gerais, pertencentes a toda a sociedade, eis que seriam mais amplos e abrangentes do que os interesses difusos e coletivos, muito embora todos configurem formas de expressão do interesse público (COSTA, 2009, p. 157). O interesse geral, ao contrário dos demais de natureza metaindividual, não importam benefício direto e pessoal aos membros da comunidade política. Ressalva-se, entretanto, a possibilidade de manejo de ação civil pública pelo Ministério Público para a tutela de interesse geral do erário em razão de previsão constitucional (COSTA, 2009, p. 158).
} 
demanda coletiva aquela cujo objeto se refira a interesse metaindividual, seja ele geral, difuso ou coletivo, ou que represente uma forma de tratamento coletivizado de interesses individuais. Partindo dessa concepção alargada, podem configurar demandas coletivas, exemplificativamente: a ação civil pública, a ação popular, o mandado de segurança coletivo, a ação de improbidade administrativa, as ações de controle concentrado de constitucionalidade, e até mesmo a recuperação judicial e a falência, sendo esta considerada forma de execução coletiva.

O uso corrente da expressão demanda ou ação coletiva, entretanto, é mais restritivo, indicando apenas aquelas que tenham por escopo a tutela de interesses difusos, coletivos em sentido estrito e individuais homogêneos ${ }^{93}$. Assim, no mais das vezes, a doutrina nacional, ao empregar a expressão demanda ou ação coletiva, está a se referir a ação civil pública, ação popular ou mandado de segurança coletivo ${ }^{94}$.

Exclui-se do conceito de ação coletiva casos em que haja uma mera pluralidade de sujeitos ocupando um dos polos da relação jurídica processual. Segundo Aluisio Gonçalves de Castro Mendes, o fenômeno do litisconsórcio tradicionalmente representa a mera cumulação de demandas singulares, constituindo fenômeno típico dos processos individuais. ${ }^{95}$ A presença de todos os sujeitos interessados no processo na qualidade de partes eliminaria a pertinência dos princípios e institutos processuais peculiares às demandas coletivas. Isso porque a legitimidade para a causa seria ordinária e os efeitos da sentença atingiriam somente aqueles que constam da relação jurídica processual. Por essa razão, para o processualista, elemento essencial para a existência de uma ação coletiva é a legitimidade extraordinária autônoma ${ }^{96}$, pela qual uma parte ideológica atuará judicialmente em nome próprio em benefício de uma pluralidade de pessoas ${ }^{97}$.

Pelo mesmo motivo, Antonio Gidi afirma que nem toda ação que tenha por objeto interesse coletivo é uma ação coletiva, eis que não é impossível que a integralidade da coletividade titular do interesse se faça nominalmente presente no polo ativo do processo em

\footnotetext{
${ }^{93}$ MENDES, 2010, p. 24. Vale ressaltar o posicionamento de Susana Henriques da Costa, para quem as ações coletivas são aquelas empregadas para a tutela de interesses metaindividuais, incluindo, assim, o interesse geral (COSTA, 2009, p. 128).

${ }^{94}$ GRINOVER, 2011, p. 34.

${ }^{95}$ MENDES, 2010, p. 21.

96 Abordada abaixo.

${ }^{97}$ MENDES, 2010, p. 21.
} 
litisconsórcio ${ }^{98}$. Para ele, ação coletiva é aquela proposta por um legitimado autônomo (legitimidade), em defesa de um direito coletivamente considerado (objeto), cuja imutabilidade do comando da sentença atingirá uma comunidade ou coletividade (coisa julgada) $" 99$.

\subsection{AGGREGATE LITIGATION (LITIGÂNCIA AGREGADA) NOS ESTADOS UNIDOS DA AMÉRICA}

Os Estados Unidos são um dos países precursores na implementação de ações coletivas, especialmente por meio das class actions ou ações de classe. Entretanto, nada obstante a atenção destacada dispensada a aludido mecanismo processual, outros instrumentos também são empregados naquele país para o trato processual coletivo dos interesses ${ }^{100}$.

Esses instrumentos são concebidos como técnicas de agregação ou como expressão de litigância agregada, que combinam demandas ou defesas de diversas pessoas sujeitas a uma resolução unificada, seja ela adjudicada ou acordada. Aludidas técnicas, de forma mais abrangente do que as ações coletivas brasileiras, dividem-se em três tipos ${ }^{101}$ :

(a) Processo coletivo (aggregate lawsuit): é um processo único que compreende um conjunto de demandas ou defesas de múltiplas partes ou pessoas representadas. Podem ser processos em litisconsórcio (joinder actions), vinculando apenas as partes; ou ações em representação (representative actions), que tem o potencial efeito de vincular terceiros representados. As class actions entram nesta categoria, mas não são as únicas nem as mais frequentes ações em representação. A categoria também inclui ações por agentes ou outros representantes autorizados da parte, ações parens patriae movidas por entes ou autoridades governamentais, ações por associações em representação de seus membros e ações com o

\footnotetext{
${ }^{98}$ GIDI, 1995, p. 15.

${ }^{99}$ GIDI, 1995, p. 16.

100 "Fewer writings focus on the forms of aggregation and carefully distinguish among proceedings of different types. Most that do address class actions. Consolidations and joinder actions have received considerably less scholarly attention. Private or informal aggregations have receives almost none" (The American Law Institute. Principles of The Law of Aggregate Litigation.St. Paul: American Law Institute Publishers, 2010, p. 15)

${ }^{101}$ O American Law Institute (ALI), prestigiosa organização criada em 1927, reúne juízes, advogados e professores de Direito e tem por objetivo elaborar estudos visando esclarecer, modernizar e por outras formas aprimorar o ordenamento jurídico. Dentre suas obras, amplamente disseminadas na comunidade jurídica norte-americana, publica o Principles of the Law of Aggregate Litigation, trabalho a respeito dos litígios coletivos, consolidando as práticas vigentes naquele país e propondo mudanças para aprimorá-las. Os mecanismos indicados seguem o princípio 1.02 e os correspondentes comentários contidos na obra.
} 
efeito de conferir representação virtual para terceiros que não sejam parte. Para que possam produzir efeitos vinculantes sobre terceiros, entretanto, normalmente devem ser obervados alguns requisitos em tais ações, tais como uma comunhão de interesses entre o representante e o representado, um real interesse por parte do representante em diligentemente demandar ou defender, atuando efetivamente nesse sentido. Se um município ajuizar demanda em face de companhias de telefonia móvel para impedi-las de instalarem antenas que atrapalhem a paisagem dos moradores da cidade, da qual resulte a permissão para a construção das antenas, os munícipes que sofram o impacto da mudança da paisagem ficarão vinculados pela coisa julgada, não podendo discutir a questão em juízo, se a municipalidade tiver atuado de forma diligente, caracterizando aquela como uma ação parens patriae ${ }^{102}$.

(b) Agregação administrativa (administrative aggregation): compreende mecanismos de reunião de diferentes processos para processamento conjunto, para o aproveitamento de atos processuais referentes à instrução, com posterior julgamento em separado, ao que se dá o nome de coordenação (coordination), ou para processamento e julgamento conjunto, ao que se dá o nome de consolidação (consolidation). Esses mecanismos incluem os bellwether trials, nos quais, em termos gerais, o juiz e as partes elegem alguns casos representativos de controvérsias repetitivas para irem a julgamento de modo a fornecer elementos para as partes de outros processos avançarem em negociações conciliatórias. As técnicas de agregação administrativas, isto é, aquelas realizadas no curso dos processos em prol da eficiência da Justiça, normalmente demandam afinidade de questões jurídicas ou factuais ${ }^{103}$.

(c) Agregação privada (private aggregation): também conhecidas como agregação informal, envolve práticas de reunião de demandas, ajuizadas ou não, ou de defesas afins por partes privadas para ganhos de escala. Reunindo recursos e esforços, diversos sujeitos ocupando posições jurídicas semelhantes ou mesmo seus advogados, são capazes de produzir um trabalho de melhor qualidade, fazendo frente a potenciais vantagens da parte adversa, caso seja um litigante habitual ${ }^{104}$.

\footnotetext{
${ }^{102}$ AMERICAN LAW INSTITUTE, 2010, pp. 10/12.

${ }^{103}$ AMERICAN LAW INSTITUTE, 2010, pp. 13/14.

${ }^{104}$ AMERICAN LAW INSTITUTE, 2010, pp. 14/15.
} 
Fica, assim, evidente a complexidade do sistema de coletivização de demandas e de defesas no sistema norte-americano, compreendendo técnicas que extrapolam a típica ação coletiva, por meio da qual um terceiro representa uma coletividade em juízo, com a produção de efeitos para todos.

\subsection{SUBSISTEMA BRASILEIRO DAS AÇÕES COLETIVAS}

Do conjunto de diplomas normativos tratando das diversas formas de expressão de ações coletivas, especialmente a Lei da Ação Civil Pública e o Código de Defesa do Consumidor, ${ }^{105}$ sustenta-se ter surgido um subsistema ou minissistema de processo coletivo. ${ }^{106}$ Nada obstante a existência de regras próprias a cada modalidade de ação coletiva derivadas das leis que as regulam ${ }^{107}$, em razão de todas terem por objeto interesses metaindividuais, concebe-se um campo de princípios e regras comuns que permite a construção de conceitos e institutos comuns estabelecendo um sistema próprio de processos coletivos $^{108}$.

Há quem defenda que tal sistema levaria ao reconhecimento de um direito processual coletivo autônomo em relação ao processo comum e seus conceitos e institutos voltados à

\footnotetext{
105 GRINOVER, 2011, p. 33.

${ }^{106} \mathrm{O}$ fenômeno da expansão da tutela jurisdicional coletiva é reconhecido por Cândido Rangel Dinamarco, para quem a noção de processo civil individualista, tal qual impregnada na regra do artigo $6^{\circ}$ do Código de Processo Civil, encontra-se excepcionada em tantos pontos que seria possível afirmar que o mesmo sistema abrigaria o individual e o coletivo, com normas comuns a ambos e normas específicas a cada. O próprio princípio constitucional do acesso ao Judiciário, conforme previsto na Constituição da República de 1988, evidenciaria essa maior amplitude de alcance da tutela jurisdicional, vez que o texto constitucional não a restringe a interesses individuais, como faziam as Constituições precedentes, prevendo, o artigo $5^{\circ}$, inciso XXXV, a possibilidade de exame judiciário de lesões ou ameaças a direitos, sem qualquer adjetivação. (DINAMARCO, Cândido Rangel. Fundamentos do Processo Civil Moderno, Tomo I. $6^{\text {a }}$ ed. São Paulo, Malheiros, 2010, p. 426.)

${ }^{107}$ Susana Henriques da Costa compartilha o entendimento de que existe um sistema próprio alusivo às ações coletivas, embora negue a existência de interdependência entre diplomas coletivos, de forma que as regras atinentes a uma dada modalidade de ação coletiva não se aplicam a outra, a não ser que haja norma expressa prevendo a sua aplicação subsidiária. "A existência de princípios gerais e comuns, entretanto, não significa a comunhão de regras específicas que a legislação crie para cada um dos instrumentos incumbidos da defesa dos interesses coletivos lato sensu. A comunhão de regras específicas, ao contrário dos princípios, somente pode decorrer por expressa previsão legal. Caso contrário, haveria a utilização de analogia para casos onde não existem lacunas jurídicas a serem preenchidas, em total contrariedade de interpretação e integração do direito" (COSTA, 2009, pp. 132/133).

108 "Por serem produto de um mesmo movimento histórico e jurídico, às leis de ação popular, ação civil pública e ação de improbidade administrativa aplicam-se os mesmos princípios e regras interpretativas previstos para os processos coletivos. São todas demandas coletivas e, como tais, sujeitas à disciplina da teoria geral do processo coletivo." (COSTA, 2009, p. 131).
} 
resolução de conflitos individuais ${ }^{109}$. Outros, entretanto, entendem que se trata de mera conformação dos mesmos institutos e conceitos do direito processual comum a situações fáticas diferenciadas, envolvendo interesses metaindividuais ${ }^{110}$.

Liderando a primeira corrente, Ada Pellegrini Grinover estabelece feições próprias para um conjunto de princípios aplicados na esfera coletiva, sem negar que a todos os ramos do processo igualmente se aplicam alguns princípios como os de índole constitucional. Aqueles com características próprias no âmbito coletivo seriam o princípio do acesso à justiça, o princípio da universalidade da jurisdição, o princípio da participação, o princípio da ação, o princípio do impulso oficial, o princípio da economia, e o princípio da instrumentalidade das formas.

Da mesma forma, os institutos fundamentais de cada esfera seriam diferenciados, especialmente no que diz respeito à legitimação, representatividade adequada, coisa julgada, pedido e causa de pedir, conexão, continência e litispendência, preclusões, competência, ônus da prova, liquidação de sentença, indenização pelos danos provocados, dentre outros institutos. Esse conjunto de princípios e institutos específicos ou com feições próprias autorizariam o reconhecimento de um Direito Processual Coletivo, como novo ramo do Direito Processual ${ }^{111}$.

Se por um lado tal diferenciação se revelou valorosa para se sustentar a relevância das demandas coletivas e da formação de princípios e institutos a elas subjacentes, inclusive justificando a promulgação de um instrumento legal destinado a disciplinar de forma geral esse subsistema, por outro contribui para uma certa imunização das demandas individuais tradicionais com relação ao influxo das inovações trazidas com os processos coletivos. ${ }^{112}$ A existência de dois sistemas, para que possam se caracterizar dessa forma, impõe que cada um seja regido por um regime metodológico próprio. A questão que se põe é a de que,

\footnotetext{
${ }^{109}$ COSTA, 2009, p. 132.

${ }^{110}$ LEONEL, 2011, pp. 103 e 136.

111 "Tudo isso autoriza a conclusão a respeito do surgimento e da existência de um novo ramo de Direito Processual, o Direito Processual Coletivo, contando com princípios revisitados e institutos fundamentais próprios e tendo objeto bem definido: a tutela jurisdicional dos interesses ou direitos difusos, coletivos e individuais homogêneos." (GRINOVER, 2011, p. 33).

${ }^{112}$ Vale notar que não se está a sustentar a existência de uma falta de contato entre os sistemas, mas do subaproveitamento das disposições dos processos coletivos para os processos individuais. Lembre-se, por exemplo, que o Código de Processo Civil sofreu influências do Código de Defesa do Consumidor no que toca ao cumprimento das obrigações de fazer ou não fazer (GRINOVER, 2011, p 25).
} 
na contemporânea sociedade de massa, também aos processos individuais devem ser previstos potenciais desdobramentos coletivos.

Como os interesses metaindividuais invariavelmente possuem uma dimensão pessoal, demandas coletivas têm repercussão individual, assim como demandas individuais podem ter efeitos coletivos. Prevê-se no primeiro caso como uma ação coletiva impactará (ou com relação a eles não produzirá efeitos jurídicos), os indivíduos membros da coletividade e as demandas individuais por eles propostas ou que possam vir a propor. Como o sistema processual coletivo diferenciou-se do sistema tradicional individualista, era de se esperar que previsse como as demandas coletivas interagiriam com as individuais. ${ }^{113}$ Não se desenvolveu, contudo, uma disciplina diferenciada para demandas individuais no que toca às suas implicações coletivas, ressentindo-se a situação de direito material subjacente de tratamento adequado às suas características.

Ou seja, o regime jurídico aplicado a uma demanda será definido de acordo com a forma que ela restar proposta. Uma vez identificada uma demanda como individual, o seu tratamento jurídico será àquele tradicional dispensado aos processos individuais. Nota-se hoje, no entanto, uma preocupação maior no trato das ações individuais, sobretudo nos casos de massa e de questões jurídicas repetitivas, prevendo-se mecanismos para o seu tratamento coletivizado ou agregado.

Considerando que a linha condutora do presente estudo se refere ao interesse, cumpre examinar as principais diferenças no que toca ao interesse processual e à legitimidade ativa nas ações individuais e coletivas.

\subsection{INTERESSE PROCESSUAL}

Como qualquer outro interesse, o de natureza processual também se perfaz como uma relação de complementariedade entre um sujeito e um bem, considerando uma necessidade daquele e a utilidade deste. A esse respeito, Rodolfo de Camargo Mancuso lembra que não se afasta daquele conceito geral de interesse, eis que "é reconhecido quando o processo se

\footnotetext{
${ }^{113}$ Nesse sentido, a disciplina da litispendência, continência, coisa julgada e prejudicialidade no que toca uma ação coletiva com relação a ações individuais.
} 
revela útil e necessário à obtenção de certa posição de vantagem, inalcançável de outro modo". Assim, apura-se a existência do interesse processual em relação à necessidade e à utilidade.

Pelo aspecto da necessidade, o que se considera diretamente não é a carência do bem da vida pleiteado pelo autor, mas sim a necessidade do processo como instrumento para obtêlo. Conforme afirma Giuseppe Chiovenda: "O interesse de agir não consiste unicamente no interesse de conseguir o bem garantido pela lei (o que forma o conteúdo do direito), mas também no interesse de consegui-lo por obra dos órgãos jurisdicionais". ${ }^{114}$ Isso quer dizer que o bem da vida ou o resultado da providência que se busca não estavam disponíveis ao demandante, de forma que ele tenha que se valer do processo para obtê-lo. Aqui se exige que a pretensão de uma parte encontre a resistência da outra, de forma que aquela dependa do Estado para fazer prevalecer sua vontade em conformidade com as normas de direito material. Nos processos de jurisdição voluntária, mesmo que todas as partes estejam de acordo com a providência pleiteada, a matéria assume tal importância social que não fica à livre disposição dos sujeitos envolvidos, necessitando-se do processo como instrumento de controle do Estado-juiz ${ }^{115}$.

A outra faceta do interesse processual concerne à utilidade. O processo deve ser capaz de proporcionar ao sujeito o bem da vida cuja obtenção constitui o objeto da necessidade que o levou a ajuizar a demanda. Considerada em outro aspecto, a utilidade corresponde à adequação. A tutela pleiteada deve ser pertinente com a crise exposta no processo de modo a que ela venha a configurar instrumento adequado para a satisfação do direito que se apresenta como causa de pedir. ${ }^{116}$

\footnotetext{
${ }^{114}$ CHIOVENDA, Giuseppe. Instituições de Direito Processual Civil. Tradução de Paolo Capitanio. Vol. I. 1. ed. Campinas: Bookseller, 1998, p. 226.

${ }^{115}$ Nesse tocante, acentua Cândido Rangel Dinamarco os dois caráteres assumidos pela jurisdição: "A jurisdição só tem caráter secundário em relação a pretensões que poderiam ser satisfeitas pelo outro sujeito: quanto a elas, o primeiro instrumento preordenado à satisfação das pretensões é o próprio sistema de deveres e obrigações, que deve motivar o obrigado, levando-o a satisfazer. Não satisfazendo, eis o conflito. No tocante às pretensões que só por via processual podem ser atendidas, a jurisdição tem caráter primário e não secundário (infra, n. 120). Em ambas as hipóteses, há sempre algum conflito como causa determinante da necessidade da jurisdição." (DINAMARCO, 2005, pp. 136/137).

${ }^{116}$ Para alguns, o interesse processual é representado pelo binômio necessidade-adequação (Dinamarco), enquanto outros concebem o trinômio necessidade-utilidade-adequação (MANCUSO, 2004, p. 160).
} 
O interesse processual não se confunde com o interesse material, sendo cada qual dotado de elementos diversos. ${ }^{117} \mathrm{O}$ interesse processual do autor, conhecido como interesse de agir, reside na obtenção, por meio do processo, de proteção ao interesse substancial lesado ou sob ameaça de lesão, sendo assim considerado em conflito com o interesse de outrem $^{118}$.

Entre eles se estabelece, entretanto, relação de complementariedade ou interdependência. Nota-se que o interesse material pode se realizar independentemente do surgimento do processual, eis que os sujeitos normalmente se comportam em conformidade com as soluções de conflitos dispostas pelas regras de direito material ou alternativamente adotam entre si solução diversa de forma voluntária. Da mesma forma, pode-se conceber o interesse processual sem que exista um interesse material juridicamente protegido que lhe dê fundamento, como nos casos de improcedência da ação.

Com base na teoria da asserção, a apuração da correspondência se dá com base na versão do autor apresentada na demanda, de forma que mesmo que posteriormente se conclua inexistir o direito por ele alegado, isso não constituirá motivo para se entender carente do interesse processual. Seja como for, sempre deve haver um interesse material que tenha levado o autor a propor a demanda, ainda que seja ele de fato desprovido de juridicidade. Entre direito de ação e direito material se estabelece uma relação de meio e fim, não sendo o processo concebido como um fim em si mesmo. ${ }^{119} \mathrm{O}$ interesse processual é, assim, sempre instrumental e mediato com relação ao interesse material.

Nota-se, entretanto, a possibilidade de não se referir diretamente a um interesse substantivo, e sim a um interesse relacionado ao próprio processo ou às garantias a ele atinentes. É o que se verifica na ação rescisória em que se objetiva a rescisão de um provimento transitado em julgado em função da violação de uma regra processual no processo que o originou, como, por exemplo, no caso da nulidade da citação do réu ${ }^{120}$. $\mathrm{O}$ objeto do interesse processual pode residir em garantir a potencial eficácia de outro

117 A distinção desses interesses em duas categorias criou, todavia, certo risco de abstracionalismo exacerbado entre o processo e a situação de direito material na fase autonomista do direito processual (MANCUSO, 2004, p. 160).

${ }^{118}$ LIEBMAN, Enrico Tullio. Manual de Direito Processual Civil, Vol. I. Tradução e notas de Cândido Rangel Dinamarco. $3^{a}$ ed., São Paulo: Malheiros, 2005, p. 206.

${ }^{119}$ MANCUSO, 2004, p. 161.

${ }^{120}$ MARINS, 2000, p. 45. 
processo, como ocorre nas ações cautelares ${ }^{121}$. Mesmo nessas hipóteses, o interesse processual é instrumental ao interesse substantivo, eis que no processo cujo resultado prático se busca assegurar, o que se pretende é a proteção ao interesse relacionado ao bem da vida em disputa ${ }^{122}$.

O autor exerce seu direito de ação sempre com o objetivo de atender algum interesse da vida, mesmo que indiretamente. Presume-se que esse seu interesse seja aquele albergado pelo direito material exposto como causa de pedir. Sob essa premissa, em termos gerais, serve o processo como mecanismo de apuração desse direito, da consequência jurídica a ele imputada e de efetivação de tal consequência ${ }^{123}$.

A configuração do interesse processual representa um mecanismo de preservação do exercício da função jurisdicional para situações de conflito real, eliminando ou restringindo o seu uso consultivo, especulativo ou meramente intimidatório por parte dos litigantes. Nesse contexto, tradicionalmente se atribuem três dados básicos ao interesse processual: certeza, juridicidade e individualização. ${ }^{124}$ Com relação ao primeiro, deve se referir a uma necessidade atual e concreta, por mais que se admita dizer respeito a uma situação iminente, como nos casos de ameaça a um direito (artigo $5^{\circ}$, inciso XXXV, da Constituição da República), servindo nessas hipóteses o processo como mecanismo a preservar um direito ainda não violado, mas em risco. O segundo indica que deve o interesse que lhe dá base ser dotado de juridicidade, tradicionalmente um direito subjetivo. $\mathrm{O}$ terceiro requer a determinabilidade do seu objeto e titular, de forma a que seja pessoal e direto ${ }^{125}$, de certa forma se ingressando no tema da legitimação para agir.

\footnotetext{
121 "Aponte-se ainda importante distinção entre o interesse cautelar - que visa à proteção da própria atividade jurisdicional - e o interesse processual na obtenção de um interesse substancial, presente no processo principal (de conhecimento e de execução). Neste, o interessado afirma quase sempre a existência de um direito subjetivo substancial a seu favor; naquele não há direito substantivo substancial a proteger (mas apenas a aparência dele)." (MARINS, 2000, p. 46).

${ }^{122}$ Considerando o interesse processual, Victor Bomfim Marins estabelece uma classificação dos interesses no seguinte sentido: "Vimos então, sob a ótica jurídica, em apertada síntese, cinco espécies de interesse, a saber: a) o interesse substancial erigido à categoria de direto subjetivo; b) o interesse substancial juridicamente protegido mas não subjetivado; c) o interesse processual preordenado a realizar o interesse substancial; d) o interesse processual tendente a assegurar a eficácia do processo principal; e) o interesse não protegido pelo direito." (MARINS, p. 46).

${ }_{123}$ Entretanto, não é incomum que outros interesses impulsionem o autor a promover a demanda, considerando as consequências que o processo, como relação jurídica que configura, pode vir a trazer para as partes.

${ }_{124}^{124}$ MANCUSO, 2004, pp. 162/163.

${ }^{125}$ MANCUSO, 2004, p. 163.
} 
Essa concepção tradicional obstaculariza a tutela jurisdicional dos interesses transindividuais, de forma a não admitir as situações envolvendo interesses sem correspondência com direitos subjetivos e sem titularidade determinada. A defesa judicial dos interesses metaindividuais, especialmente os difusos, teve como um de seus pressupostos a alteração dessa noção de interesse processual para abarcar interesses com reconhecida relevância social não contemplados na concepção tradicional de direito subjetivo. A titularidade do interesse deixa de ser um critério absoluto para a se admitir a tutela, reconhecendo-se a existência de interesses sem titularidade determinada que, por sua relevância, são merecedores de proteção.

Fala-se de um esmorecimento da personalização do interesse processual, perdendo o rigor da exigência de se tratar de interesse pessoal e direto. ${ }^{126}$ Nesse contexto, propugna Rodolfo Camargo Mancuso por uma segunda ruptura no entendimento do interesse processual, sucedendo aquela em que ganhou certa autonomia do interesse material. Nas palavras do autor:

o interesse processual será buscado em outros parâmetros, como a relevância social; a identificação do portador judicial com o segmento social, grupo ou categoria concernentes; a constatação de que o interesse em causa não estão sendo tutelado na instância administrativa de modo adequado suficiente. Tudo isso justifica a necessidade de um "momento judiciário" para que esses interesses sejam reconhecidos e saiam do limbo jurídico onde estiveram tanto tempo relegados ${ }^{127}$.

No caso das ações coletivas, questiona-se qual seria o interesse material a dar substrato ao interesse processual da parte a figurar no polo ativo do processo, vez que o direito defendido não lhe seria próprio, mas pertencente a uma coletividade. Para examinar tal inquirição, cumpre primeiro observar um fenômeno pertinente aos processos tradicionais.

Os conflitos de interesse entre sujeitos, no mais das vezes, não encerram apenas e tão somente o choque entre um interesse de uma parte com outro interesse da outra. Como

\footnotetext{
${ }^{126}$ MANCUSO, 2004, p. 166.

${ }^{127}$ MANCUSO, 2004, pp. 169/170.
} 
cada indivíduo é um centro de inúmeras necessidades, de ordem material e moral, é comum que se estabeleça uma pluralidade de interesses em cada um que, de alguma forma, se relacionem com uma pluralidade de interesses de outro. O processo não funciona como um veículo para externalização de todos os conflitos existentes entre as partes, exigindo-se, em primeiro lugar, que se apresente como um conflito jurídico. O cônjuge insatisfeito com o término do casamento e com o novo relacionamento amoroso do seu antigo consorte, não poderá vir a juízo pleitear a extinção da nova união e o restabelecimento da anterior. No entanto, possuindo bases para tanto, poderá formular pedidos relativos à meação, alimentos e à guarda dos filhos menores. ${ }^{128}$ Moradores de um edifício com vista para o mar, em circunstâncias normais, não terão direito de impedir a construção de edificação em outro imóvel que lhes retire a vista privilegiada. Poderão, entretanto, ir a juízo requerer a suspensão das obras realizadas durante a noite por causar interferência irrazoável ao sossego, em violação ao direito de vizinhança. Em ambos os casos, o processo não transparecerá na sua inteireza os conflitos estabelecidos entre as partes, deixando de incluir aqueles em que o interesse do autor não esteja albergado em um direito ${ }^{129}$.

Em outros, o autor vale-se do processo para impor ao réu gravame superior ao necessário para a satisfação do seu interesse legítimo, buscando, desse modo compelir o demandado a ceder a esse interesse pelo receio do mal maior que pode lhe resultar do processo. Também ocorrem casos em que o interesse que o autor pretende fazer prevalecer sequer se insere no objeto do processo, representando este mero instrumento para tentar acarretar o atendimento indireto daquele. Ressalte-se que, apesar desse uso do processo ser abusivo, em circunstâncias normais sua comprovação é tarefa de elevada dificuldade, sobretudo em razão da demanda vir calçada em um aparente interesse juridicamente protegido.

Considerando as demandas coletivas, como o autor da demanda não é titular do direito protegido na causa, desponta, em tese, certa dificuldade em se identificar qual o interesse pessoal que lhe terá levado a mover a ação, despontando o risco de que, na realidade, o objetivo buscado pelo demandante não seja propriamente a tutela coletiva pleiteada. Por

\footnotetext{
${ }^{128}$ Apesar de não transparecer no processo, aquele conflito a respeito do relacionamento amoroso em si também serve de motivação para a parte ajuizar a demanda com relação a esses outros conflitos e possivelmente adotar uma postura mais litigiosa com relação à parte adversa.

${ }^{129}$ Nessas hipóteses, não raro o autor venha a ter êxito na sua demanda, não restará plenamente satisfeito por não ter aquele outro seu interesse atendido. Daí porque certos mecanismos alternativos de resolução de conflitos, tais como a mediação e a conciliação, podem proporcionar uma solução para a disputa mais adequada nesses casos, permitindo às partes que discutam e considerem seus conflitos na sua integralidade.
} 
mais que esse risco também exista nos processos tradicionais, conforme observado acima, fato é que se não houver um elemento considerado suficiente e legítimo para fundamentar a conduta do autor, o risco de uso indevido do processo será maior, causando efeitos mais danosos ao se considerar que o direito material a ser tutelado pertence a uma coletividade que não participará diretamente do processo.

A solução apontada se refere ao requisito da pertinência temática, entendida como um elemento da legitimação ativa ${ }^{130}$. Além de se restringir os legitimados a defender interesses metaindividuais em juízo a determinadas espécies de entes, impõe-se que possuam um elo suficiente com o interesse defendido, de modo a gerar nível mais elevado de segurança de que o legitimado atuará como um representante adequado da coletividade.

Tratando-se de processo proposto por membro da coletividade titular do interesse, há de se reconhecer a pertinência temática na medida em que o objeto do interesse seja indivisível, ou seja, se a satisfação da necessidade individual do sujeito importar de forma indispensável a satisfação de necessidade similar de todos os demais membros da classe. ${ }^{131}$ Um dos principais problemas em se admitir demandas coletivas propostas por um membro da coletividade diz respeito à possibilidade do seu interesse ser desmembrado daquele compartilhado com o grupo. Não era incomum, por exemplo, que um credor viesse a ajuizar pedido de decretação de falência de empresa devedora com vistas a compeli-la a efetuar o pagamento do seu crédito para evitar a quebra. Servia o pedido de falência, assim, como um substituto agravado do processo executório individual. Atenta a essa estratégia, a jurisprudência passou a indeferir aludidos pedidos em que os valores envolvidos não fossem de vulto, por mais que fossem devidos ${ }^{132}$.

No caso de outros legitimados que não seriam direta e pessoalmente contemplados pela tutela pleiteada, tipicamente certas espécies de pessoas jurídicas ou outros tipos de entes

\footnotetext{
${ }^{130}$ Abordada no próximo tópico.

131 Nada obstante o reconhecimento da pertinência temática, pode não ser o demandante individual representante adequado da coletividade em virtude de outros fatores, tais como, a falta de recursos disponíveis para despender no processo.

132 "FALÊNCIA E COBRANÇA. O Juiz deve indeferir o pedido de falência que visa, unicamente, forçar o devedor impontual ao pagamento. A ameaça de quebra não substitui o processo de execução ou a ação de cobrança. Cumpre ao Judiciário coibir tais abusos. Precedentes citados - do STF: RE 87.405-4-RJ - do STJ: REsp 157.637-SC, DJ 13/10/1998, e REsp 1.712-RJ, DJ 9/4/1990. REsp 136.565-RS, Rel. Min. Ruy Rosado, julgado em 23/2/1999." (Superior Tribunal de Justiça. Informativo no 0008 do STJ, Período: 22 a 26 de fevereiro de 1999).
} 
institucionalizados, o que se exige é que a defesa do direito concreto em questão faça parte de suas atribuições estatutárias, constitucionais ou legais. O tema será novamente abordado no próximo tópico, referente à legitimidade ativa.

\subsection{LEGITIMIDADE}

Tradicionalmente, com apoio na teoria de Enrico Tullio Liebman, entende-se por legitimidade para agir ${ }^{133}$ a relação de correspondência entre as posições de autor e réu na relação jurídica de direito processual e as de sujeito ativo e passivo na relação jurídica de direito material ${ }^{134}$.

Tal concepção, segundo Susana Henriques da Costa, pode ser sintetizada na expressão 'pertinência subjetiva da ação', cunhada pelo autor italiano, que exprime a identidade entre os sujeitos das relações jurídicas de direito material e processual ${ }^{135}$, de forma que haveria legitimidade para agir se, por exemplo, uma demanda reparatória viesse a ser proposta por alguém que teve seu pretenso direito lesado em face de quem supostamente o lesou.

Cândido Rangel Dinamarco, de forma semelhante, lembrando que se trata de uma das condições da ação, conceitua a legitimidade ad causam como "relação de legítima adequação entre o sujeito e a causa" ${ }^{136}$. Para Dinamarco, a legitimidade se encontra em íntima relação com outra condição da ação: o interesse de agir $^{137}$. Somente o ente legitimado a figurar no polo ativo da demanda poderia ter interesse processual. Isso porque para os entes que não sejam legitimados, o provimento jurisdicional pleiteado não seria capaz de proporcionar proveito correspondente ao direito afirmado na causa de pedir, eis que tais entes não seriam titulares desse direito. $\mathrm{O}$ irmão do credor seria ilegítimo para

\footnotetext{
${ }^{133}$ Há de se mencionar, a despeito de se tratar de questão elementar, que a legitimidade para a causa se divide em legitimidade ativa, referente ao autor, e legitimidade passiva, referente ao réu.

${ }^{134}$ COSTA, 2005, p. 63.

${ }^{135}$ DINAMARCO, 2001, p. 64.

136 DINAMARCO, Cândido Rangel. Instituições de Direito Processual Civil. Volume II. São Paulo: Malheiros, 2001, p. 303.

${ }^{137}$ Aduz Cândido Rangel Dinamarco que "Em rigorosa técnica processual, a legitimidade ad causam inserese no âmbito do interesse de agir porque sua falta traduz-se em ausência de utilidade do provimento jurisdicional." (DINAMARCO, 2001, p. 305).
} 
ajuizar demanda condenatória em face do devedor pleiteando o pagamento do débito na medida em que o direito creditório não lhe pertenceria ${ }^{138}$.

Assim é que uma das expressões do interesse processual refere-se à legitimidade da parte. Admite-se a figurar em um dos polos da relação jurídica processual os sujeitos que, por tomarem parte na relação jurídica substancial subjacente, tenham interesse na tutela buscada, ou seja, o provimento possa lhes ser útil de alguma forma. A legitimidade é, desse modo, o elo entre as partes da relação jurídica de direito material e as partes do processo.

Vale ressaltar que, sem que se pretenda explorar as diferentes teorias a respeito das condições da ação, segundo a teoria da asserção, tendo por adeptos, dentre outros, José Carlos Barbosa Moreira, José Roberto dos Santos Bedaque, e Kazuo Watanabe ${ }^{139}$, a apuração da legitimidade para a causa faz-se, regra geral, no início do processo pelo exame do que vem afirmado pelo autor na petição inicial, independentemente da investigação da veracidade e validade de tais alegações, o que consistiria matéria do mérito da causa. ${ }^{140}$ Assim, na ação em que se afirma que o dano foi causado pelo réu da demanda, mas que no transcurso do processo se constata que foi causado por terceiro, não se estaria diante de carência de ação, mas sim de improcedência do pedido reparatório formulado.

A regra a respeito da legitimação, no sistema processual brasileiro, vem veiculada pelos artigos $3^{\circ}$ e $6^{\circ}$ do Código de Processo Civil de 1973, segundo os quais, respectivamente, "Para propor ou contestar ação é necessário ter interesse e legitimidade" e "Ninguém poderá pleitear, em nome próprio, direito alheio, salvo quando autorizado por lei".

Nota-se que tal concepção de legitimidade ativa prevista no aludido artigo $6^{\circ}$ tem índole eminentemente individualista e é voltada para um sistema de direitos majoritariamente patrimoniais e disponíveis. Se aquele que se entende titular de um direito violado ou

\footnotetext{
${ }^{138}$ Desse entendimento não parece destoar a doutrina de Liebman, para o qual: "Como direito de invocar a tutela jurisdicional, a ação apenas pode pertencer àquele que a invoca para si, com referência a uma relação jurídica da qual seja possível pretender uma razão de tutela a seu favor. Já se disse logo acima que o interesse de agir se destina a remover a lesão de um interesse substancial que se diz protegido pelo direito; ele só pode, pois, ser invocado [fato valere] por aquele que se afirma titular de interesse substancial cuja tutela vem pedir em juízo." (LIEBMAN, 2005, p. 209).

${ }^{139}$ Conforme apontamento de Susana Henriques da Costa (COSTA, 2005, p. 51).

${ }^{140}$ Susana Henriques da Costa chega a afirmar que são: "Intimamente ligados, portanto, as condições da ação legitimidade de agir e interesse processual, a ponto de, em certas hipóteses, confundirem-se." (COSTA, 2005, p. 67).
} 
ameaçado não busca sua tutela em juízo, não haveria razão, em tese, para que um terceiro pudesse ajuizar a demanda em seu lugar. Como poderia o titular dispor de seu direito, somente a ele caberia exigi-lo em juízo. Essa é a chamada legitimidade ordinária, a regra geral considerada na construção do sistema processual individual tradicional.

Entretanto, esse próprio artigo $6^{\circ}$ prevê a possibilidade, excepcional, diga-se de passagem, de casos em que não se aplica tal regra geral, ou seja, em que se admite que sujeitos pleiteiem em nome próprio, direito alheio. Trata-se da chamada legitimidade extraordinária $^{141}$, cujo caráter excepcional fica evidente ao se considerar que somente é admitida nos casos previstos em lei, não concebendo outras ampliações ${ }^{142}$.

Nesses casos, vale-se da técnica de substituição processual, eis que o autor da demanda substituirá no processo a parte da relação jurídica de direito processual. Não age o substituto visando a satisfação de seu próprio interesse, razão pela qual não é atingido pelos efeitos da decisão, os quais, de outro modo, afetarão o substituído como se parte fosse no processo.

De acordo com Giuseppe Chiovenda:

Quando existem vários interessados no concernente a um mesmo objeto ou patrimônio, ou as ações relativas a determinado patrimônio estejam vedadas ao sujeito dele; pelo que, pode-se discutir se determinada ação pertença a cada um dos interessados, ou ao conjunto deles em sua representação legal, ou ao patrimônio considerado como entidade. São casos ocorrentes na comunhão; na sociedade; no patrimônio total; no patrimônio hereditário em caso de separatio bonorum; na herança jacente; no patrimônio sob seqüestro; na falência; e, enfim, nas comunidades administrativas e políticas. Aí, porém, é preciso distinguir a questão da legitimatio ad

\footnotetext{
${ }^{141}$ Susana Henriques da Costa, em vista dessas duas espécies de legitimação, formula o seguinte conceito: "É legitimada a parte que detém a titularidade ativa da relação jurídica de direito material afirmada na demanda em face de quem é a titular do polo oposto, ou em casos excepcionais, aquela que a lei permite que defenda, em nome próprio interesse alheio" (COSTA, 2005, p. 68).

${ }^{142}$ A legitimidade extraordinária não se apresenta nos casos de representação processual. O representante não é parte no processo, dele participando em nome e em benefício do representado. Nesses casos, a verdadeira parte é o representado (DINAMARCO, 2001, p. 308).
} 
causam da questão - que amiúde se apresenta - da substituição processual: muitas vezes um direito, que se reconhece pertencer a uma pessoa ou a uma entidade, faz-se valer em juízo por uma outra pessoa, mas em nome próprio, não como representante. Assim acontece na ação popular supletiva (supra, nos 18 e 20; adiante, $\mathrm{n}^{\circ}$ 224) ${ }^{143}$.

Traçando um quadro sintético acerca das diferentes classificações a que se sujeita a legitimação extraordinária, sobretudo apoiando-se na doutrina de José Carlos Barbosa Moreira, Aluisio Gonçalves de Castro Mendes ${ }^{144}$ indica que pode se tratar de legitimação subordinada ou autônoma, dependendo se estiver condicionada à presença do legitimado ordinário no processo. Se o legitimado autônomo puder desde logo ajuizar a demanda, sua legitimação será primária, mas se apenas puder propor a demanda em caso de inação por parte do legitimado ordinário, então sua legitimação será subsidiária.

Em se tratando de legitimidade autônoma, será exclusiva se o ordenamento privar aquele que seria o legitimado ordinário de ocupar a posição de parte principal do processo, reservando a mesma apenas para o legitimado extraordinário. De outro modo, caso ambos possam promover a ação como parte principal, então se estará diante de legitimação concorrente. Se houver mais de uma pessoa simultaneamente autorizada a propor a ação como legitimado extraordinário, admitindo-se inclusive o litisconsórcio entre elas, estar-seá diante de legitimidade disjuntiva.

De modo geral, a doutrina aduz de forma indistinta à figura da substituição processual nos casos da legitimação extraordinária, considerando os termos com o mesmo conteúdo semântico. José Carlos Barbosa Moreira, no entanto, aponta haver uma impropriedade nesse uso indiscriminado dos termos, vez que, a rigor, só se poderia falar em substituição processual nas hipóteses de legitimidade autônoma exclusiva, pois fora desses casos não haveria verdadeira "substituição" (no sentido de entrada de um no lugar do outro) do legitimado ordinário, vez que este também poderia participar da demanda na qualidade de

${ }^{143}$ CHIOVENDA, 1998, p. 225.
${ }^{144}$ MENDES, 2009, pp. $758 / 759$. 
parte. Feita tal ressalva, observa-se que, nos termos do uso disseminado, as expressões são aqui empregadas de forma indistinta.

Nada obstante as diferentes espécies em que se divide a legitimação extraordinária, verifica-se nos casos em que é admitida, a existência de algum liame entre o legitimado extraordinário e a situação jurídica objeto da demanda, de forma que a tutela do direito do substituído em certa medida represente um benefício para o substituto. Assim é que a lei alavanca tal interesse indireto do substituto à condição análoga ao interesse de agir ${ }^{145}$.

Aludindo à doutrina de José Carlos Barbosa Moreira, Aluisio Gonçalves de Castro Mendes aponta que os casos de legitimidade extraordinária, a lei confere eficácia legitimante a situação subjetiva diversa da que é levada a juízo, geralmente partindo da premissa da existência de um vínculo suficientemente intenso entre ambas as situações (i.e., a levada a juízo e a utilizada como critério para a concessão extraordinária de legitimidade) ${ }^{146}$.

No sistema processual tradicional individualista prevalece a lógica da legitimidade ordinária. Ao pretenso titular do direito subjetivo se confere o poder de exigir o cumprimento de seu direito como exercício de liberdade. Desse modo, somente a ele caberia ajuizar uma demanda tendente a satisfazer o seu direito. A essa realidade, contudo, não se adéqua a tutela dos interesses metaindividuais na medida em que os titulares dos mesmos não compõem uma entidade única capaz de decidir a respeito da conveniência de buscar a sua proteção jurídica ${ }^{147}$.

Necessário se fez, assim, o desenvolvimento de mecanismos viabilizadores da defesa judicial de tais interesses por quem viesse fazer as vezes do seu titular, utilizando-se da

\footnotetext{
${ }^{145}$ Segundo Cândido Rangel Dinamarco: "Compete ao legislador e não ao juiz a determinação dos casos em que se concede essa legitimidade (CPC, art. $6^{\circ}$ ) e ele o faz sempre em virtude de alguma espécie de relação entre o sujeito e o conflito. Sempre o substituto processual é o destinatário de algum benefício indireto associado à iniciativa que tomar - porque, sem esse benefício e portanto sem poder esperar qualquer utilidade do provimento que pede, não haveria por que instituir sua legitimidade ad causam." (DINAMARCO, 2001, p. 309).

${ }^{146}$ MENDES, 2009, p. 758.

${ }^{147}$ Por mais que em certa medida aludidos interesses pudessem vir a ser tutelados por meio de ações ajuizadas por sujeitos com interesses pessoais compreendidos no interesse metaindividual, hipótese de ação individual com efeitos coletivos, diversos fatores, como os elevados custos do processo (em sentido lato) quando sopesados com o proveito individual que poderia advir para tais sujeitos constituiria fator de desestímulo à tal prática. Ademais, desponta o risco do interesse pessoal do indivíduo descolar-se do interesse coletivo defendido de forma subjacente.
} 
técnica da substituição processual ${ }^{148}$. Para enfrentar esta questão, diversas foram as construções implementadas nos sistemas jurídicos ao redor do mundo, valendo-se do mecanismo da substituição processual ${ }^{149}$.

Há de se notar, entretanto, a existência de divergência de entendimentos a respeito da natureza da legitimação nas ações coletivas. Nesse tocante, Aluisio Gonçalves de Castro Mendes aponta a existência de pelo menos três posições. Há quem entenda se tratar de legitimação ordinária, notadamente quando o legitimado é o Ministério Público, eis que é sua atribuição institucional própria promover a tutela dos interesses transindividuais na medida em que configurem direitos sociais.

De outro modo, segundo a corrente capitaneada por Nelson Nery Junior e Rosa Maria de Andrade Nery, a legitimação seria autônoma, não podendo ser classificada na dicotomia clássica legitimação ordinária-extraordinária, porquanto esta diria respeito a casos envolvendo direitos individuais apenas. Para os aludidos autores, seria incorreto considerar que nas ações visando tutelar interesses difusos ou coletivos os legitimados estariam defendendo direito alheio em nome próprio, na medida em que os titulares de tal direito não seriam identificados, impossibilitando-se a propositura da ação por eles enquanto classe ou grupo de pessoas.

Em outro sentido, de acordo com o entendimento que prevalece na jurisprudência, estar-seia mesmo diante de legitimação extraordinária, pois nada obstante a dificuldade ou inviabilidade de identificação dos titulares do interesse a ser tutelado, fato é que o legitimado defenderá em nome próprio interesse que não lhe pertence. Ademais, mesmo no

\footnotetext{
${ }^{148} \mathrm{O}$ fato de se estar diante de hipótese de legitimação extraordinária, todavia, não quer dizer que o interesse que embasa a ação deixa de ter índole individual. Por vezes o substituto ajuíza a demanda de forma a satisfazer necessidade individual do substituído, mas com vistas a que sirva de meio para a satisfação de um interesse particular do substituto. No exemplo clássico do mandado de segurança impetrado pelo segundo colocado em concurso público visando seja o primeiro colocado nomeado a uma das vagas disponíveis, com base no artigo $3^{\circ}$ da Lei do Mandado de Segurança (Lei $n^{\circ} 12.016$, de 7 de agosto de 2009), o segundo colocado ajuíza a medida porquanto somente poderá ser nomeado (seu interesse individual) depois daquele melhor classificado.

${ }^{149}$ CAPPELLETTI e GARTH, 1998, pp. 49/67. De toda forma, nas últimas décadas a legitimidade extraordinária vem sendo adotada como mecanismo de viabilização de ações coletivas, destacando Cândido Rangel Dinamarco que "É crescente o emprego da técnica da legitimidade extraordinária para causas referentes a direitos e interesses supra-individuais. Tal é o sinal da transmigração do individual para o coletivo, que se revela como uma das características mais destacadas das recentes evoluções do direito processual no Brasil (Barbosa Moreira) (supra, nn. 60, 98, 107)" (DINAMARCO, 2001, p. 309).
} 
caso em que o legitimado faça parte do grupo dos titulares do interesse objeto da ação, recairia sobre ele uma legitimação composta, a conjugar interesse próprio com o alheio.

Em virtude das peculiaridades dos interesses transindividuais, muito se discute a respeito dos entes que deveriam receber a legitimação para defendê-los em juízo, contrapondo-se os prós e contras da opção por particulares (e.g., cidadãos no caso de ação popular), por entes públicos (e.g., Ministério Público e Defensoria Pública para a propositura, dentre outras, de ação civil pública), por entidades da sociedade civil (e.g., associações), dentre outros. As preocupações recaem inclusive sobre o vínculo do legitimado com o interesse a ser tutelado, a sua capacidade de defendê-lo de forma satisfatória, e a imposição de requisitos em demasia que acabariam por limitar de forma indevida o acesso à justiça.

A esse respeito, em observância ao princípio geral da legitimidade extraordinária, exige-se certo vínculo entre o substituto e o substituído, ou, entre o substituto e a relação jurídica de direito material da qual o substituído é parte. Sem que haja esta proximidade entende-se não haver condições mínimas para que um efetivamente represente os interesses do outro.

Em sede de ações coletivas esse vínculo é apurado por meio da chamada representatividade adequada. Trata-se de conceito cunhado nos Estados Unidos servindo como um dos requisitos de admissibilidade das chamadas class actions naquele país. Nessa seara requer-se que o representante da classe cujo interesse se defende no processo reúna certas características que minimamente assegurem sua atuação adequada em benefício da classe. Os critérios para apuração da representatividade adequada no direito norteamericano não se encontram expressos na legislação processual, concedendo-se espaço para construção jurisprudencial. Esse controle é realizado pelo juiz em cada caso concreto em face das circunstâncias que se apresentam, normalmente em uma fase inicial do processo na qual ao juiz é dado decidir se o caso pode ser processado ou não como uma ação coletiva. De acordo com Suzana Henriques da Costa:

A representatividade adequada consiste na existência de um vínculo entre a situação de direito material discutida em juízo e o legitimado extraordinário que, primeiramente, justifique a sua posição de defensor daquele direito e, ainda, garanta o seu 
comprometimento com a busca de um resultado favorável do processo $^{150}$.

Ao garantir-se a representatividade adequada, busca-se legitimar a atuação do representante da coletividade, de modo a justificar que os efeitos da decisão alcancem todos os membros do grupo, nada obstante não tenham participado diretamente do processo.

No direito brasileiro, a apuração da representatividade adequada se faz com base em critérios mais objetivos. Há quem entenda, aliás, que os critérios para essa aferição decorrem somente da lei. A esse respeito, nota-se que o artigo $5^{\circ}$ da Lei de Ação Civil Pública admite no rol dos legitimados somente aquelas associações constituídas há pelo menos um ano e que incluam nas suas finalidades institucionais a proteção do interesse metaindividual em questão. Ademais, por meio do artigo 82, inciso III, do Código de Defesa do Consumidor, prevê-se serem legitimados as entidades e órgãos da Administração Pública direta e indireta, mesmo que desprovidos de personalidade jurídica, na medida em que contenham nas suas atribuições a defesa do direito metaindividual em questão. Esses requisitos, sob essa ótica, seriam os únicos previstos no direito brasileiro como medidas de apuração da representatividade adequada. Por consequência, ao juiz não seria dado avaliar se os demais legitimados caracterizariam representantes adequados da coletividade, não lhe sendo permitido examinar qualquer outra circunstância do caso concreto senão aquelas fixadas na lei.

A jurisprudência, entretanto, desenvolveu entendimento de que não basta mera previsão legal da legitimação, fazendo-se também necessário que o representante institucional da coletividade indicado mantenha vínculo com o interesse defendido na demanda, apuradose o mesmo com base nas suas atribuições estatutárias e institucionais, constituindo, assim, o requisito da pertinência temática ${ }^{151}$.

Concede-se, desse modo, ao juiz brasileiro certa margem para apuração em cada caso concreto da representatividade adequada do substituto processual por meio da pertinência

${ }^{150}$ COSTA, 2009, p. 190.

${ }^{151}$ COSTA, 2009, p. 193. 
temática não só com relação às associações e entidades públicas, mas a todos os legitimados, inclusive o Ministério Público ${ }^{152}$.

O rol dos legitimados ativos para propositura de demandas coletivas varia em função da espécie de demanda conforme regulada em lei. Na sequência serão abordados os principais entes aos quais é reconhecida tal legitimidade no direito processual brasileiro.

Para ações populares, entende-se legitimado, em caso de legitimidade extraordinária, autônoma, concorrente e disjuntiva, o cidadão, entendido como o sujeito que reúna as condições de brasileiro, pessoa natural e eleitor. Nos seus contornos modernos e atuais, a ação popular encontra-se em linha com o Estado Democrático de Direito, representando um instrumento de cidadania e participação política do cidadão, atendendo os ditames da democracia direta. Daí se requerer que o legitimado ativo encontre-se no gozo dos seus direitos políticos para que possa propor a demanda.

Há inclusive quem entenda que o autor popular possui legitimidade ordinária para agir em juízo, eis que estará exercendo um direito político próprio e individual referente à participação na atuação e na fiscalização da atividade estatal. Apesar dos argumentos apresentados, não se parece estar efetivamente diante de um caso de legitimidade ordinária, eis que o autor individual estará defendendo um interesse metaindividual que não lhe pertence, muito embora também lhe diga respeito. O direito de participação e fiscalização atribuído ao cidadão não configura o objeto da ação popular, mas sim um pressuposto para a legitimidade do autor e o reconhecimento de sua representatividade adequada. De acordo com Suzana Henriques da Costa:

Como o interesse geral não pertence ao cidadão da ação popular, não é possível sustentar que a ação popular traduz hipótese de legitimidade ordinária. Trata-se de genuíno caso de legitimidade extraordinária, na qual a lei dá permissão para determinada pessoa

152 A própria lei conteria hipótese em que o juiz teria certa margem para definir a representatividade adequada, podendo relevar o requisito do prazo de pré-constituição das associações. 
requerer a tutela jurisdicional no interesse alheio, mesmo que não seja ela a titular do direito material cuja proteção se pleiteia ${ }^{153}$.

O Ministério Público, instituição que com a Constituição de 1988 ganhou autonomia e independência em relação ao Poder Executivo, possui ampla legitimidade para a defesa de interesses de relevância social, conforme previsão da Constituição da República, que, em seu artigo 127 determina incumbir-lhe a "defesa da ordem jurídica, do regime democrático e dos interesses sociais e individuais indisponíveis", e em seu artigo 128, inciso III, determina caber-lhe "promover o inquérito civil e a ação civil pública, para a proteção do patrimônio público e social, do meio ambiente e de outros interesses difusos e coletivos" $^{154}$.

No nível infraconstitucional diversos diplomas preveem a legitimidade do Ministério Público para a propositura de ações coletivas, incluindo a ação civil pública (artigo $5^{\circ}$ da Lei de Ação Civil Pública - Lei 7.347/1985, artigo 82, inciso I, do Código de Defesa do Consumidor - Lei 8.078/1990, e artigo 25, inciso IV, da Lei Orgânica Nacional do Ministério Público - Lei 8.625/1993), e a ação de improbidade administrativa (artigo 17 da Lei 8.429/1992). Nesse tocante, vale ressaltar que se considera o Ministério Público o único ente legitimado a promover ação civil pública para a tutela do patrimônio público na sua vertente exclusivamente patrimonial, não como decorrência da legislação ordinária, mas por previsão constitucional ${ }^{155}$.

${ }^{153}$ COSTA, 2009, p. 203. A respeito desse assunto, prossegue a autora: "Resta claro, portanto, que o direito político do cidadão de participar e fiscalizar o Estado é o fundamento para a concessão, pelo legislador, de legitimidade extraordinária para que ele proponha ação popular. Não significa, entretanto, que os interesses ao respeito à moralidade administrativa e à higidez do patrimônio público, em si, sejam de titularidade do cidadão. Trata-se de direitos e interesses diversos, com naturezas jurídicas diferentes, posto que o primeiro (direito de participação e fiscalização) é individual, e o segundo (direito ao respeito à moralidade administrativa e à higidez do patrimônio público), metaindividual. Esses direitos se relacionam, mas não se identificam, não podendo, portanto, serem confundidos".

${ }^{154}$ Também é o Ministério Público legitimado a promover outros instrumentos coletivos como os referentes ao controle concentrado de constitucionalidade (artigo 103, inciso VI, da Constituição da República e artigo $2^{\circ}$, inciso I da Lei 9.882/1999), bem como a requerer a aprovação, revisão ou cancelamento de súmula vinculante (artigo 103-A da Constituição da República).

${ }^{155}$ A despeito da expressa previsão legal, há quem entenda que o Ministério Público não poderia buscar a tutela do patrimônio público e da moralidade administrativa, sendo inconstitucionais quaisquer disposições em sentido diverso, eis que: (i) o erário não constituiria um interesse difuso, tendo por titular a Fazenda Pública, ficando a legitimidade do Ministério Público restrita ao âmbito dos interesses difusos e coletivos; (ii) representaria restrição indevida da esfera de atividade dos advogados, conforme prevista no artigo 133 da Constituição da República; e (iii) importaria invasão do escopo atribuído pela norma constitucional para as ações populares, de iniciativa do cidadão. Essa, entretanto, não parece ser a interpretação mais adequada da questão. A disposição do artigo 127, caput, da Constituição de 1988 não parece restringir a área de atuação do Ministério Público aos interesses difusos e coletivos, eis que não se limitou o conceito de patrimônio 
Muito embora não se conceda legitimidade ao Ministério Público para o ajuizamento de ações populares, reservadas somente aos cidadãos, prevê-se a possibilidade do Parquet assumir o polo ativo da demanda. Em conformidade com o artigo $9^{\circ}$ da Lei de Ação Popular, nos casos em que o autor popular desistir da demanda ou der causa à extinção do processo sem resolução de mérito, será dada a oportunidade tanto para outros cidadãos quanto para o Ministério Público de tomarem o seu lugar na ação. A Lei de Ação Civil Pública, em seu artigo $5^{\circ}, \S 3^{\circ}$, prevê, de forma semelhante, a possibilidade do Ministério Público ou outro co-legitimado para a ação civil pública de tomar posição no polo ativo do processo no caso de desistência ou abandono da causa pelo autor original.

Justifica-se tal possibilidade prevista em lei por razões de economia processual, não havendo razões para impedir outro legitimado de aproveitar os atos já praticados no processo para defender os mesmos interesses, que, afinal, dizem respeito a uma coletividade que não se alterará em função da mudança de quem está a representá-la. Ademais, impor como única solução possível a extinção do processo e a propositura de nova demanda por um dos co-legitimados atentaria contra a efetividade do processo, com o risco de provocar o aumento da lesão aos interesses metaindividuais em questão em função da demora prolongada para a prolação de sentença de mérito e a obtenção da tutela jurisdicional pleiteada.

Por razão não menos relevante, esse mecanismo de substituição também tem o condão de prevenir, em certa medida, eventuais conluios entre o autor original da demanda e o réu, bem assim o uso da demanda pelo autor como uma forma de pressionar o réu ao atendimento de outros interesses estanhos à causa. Como as possibilidades e os parâmetros

público à sua acepção não patrimonial. Não se justificaria, ademais, uma interpretação restritiva, inclusive considerando a relevância do interesse a ser tutelado. O Superior Tribunal de Justiça reconhece a possibilidade da atuação do Ministério Público nessa seara, editando nesse sentido a Súmula 329. Ademais, ao agir nessa seara, não estaria o Ministério Público agindo na qualidade de representante do órgão público ou substituindo-o na defesa de interesse secundário, e sim protegendo o interesse público primário quando o interesse perseguido pela Administração Pública no caso tenha dele se distanciado, daí porque se afirmar que a sua legitimidade nessa hipótese seria subsidiária. Também não haveria afronta à esfera de atuação dos advogados, na medida em que se reconhecem diversas áreas nas quais se pode atuar em juízo sem a representação de advogado (e.g., processos até certa alçada perante os Juizados Especiais, ou perante a Justiça do Trabalho), bem assim porque a própria Constituição previu os campos de atuação do Ministério Público sem impor qualquer exigência a respeito da assistência de advogado. Por fim, não há invasão indevida à esfera de cabimento da ação popular, mas apenas a sobreposição de instrumentos para a tutela dos mesmos interesses, como ocorre com relação a outras demandas, o que, diante da relevância dos interesses em questão, não deveria ser reprimido, e sim incentivado. (COSTA, 2009, pp. 208/228). 
de eventuais acordos no âmbito de demandas coletivas são restritos, nessas situações o que o autor teria de mais valioso a indevidamente oferecer ao réu seria causar o término do processo sem resolução de mérito por abandono ou desistência. Ao se prever a possibilidade de outros entes legitimados assumirem o lugar do aludido autor, retira-se o seu poder de oferecer ao réu o fim da demanda em troca da satisfação de algum outro interesse seu. Por decorrência, se desestimularia o emprego extorsivo das ações coletivas ou mesmo tentativas do réu de ludibriar o autor a desistir da causa.

Nota-se que para ingressar no lugar do autor da demanda coletiva deve o interesse por ela perseguido fazer parte das atribuições do Ministério Público. Nesse tocante, lembra Susana Henriques da Costa que não faz parte de tais atribuições a defesa da moralidade administrativa sem repercussões no patrimônio público ou ligações com atos de improbidade administrativa, de modo a não se admitir a atuação da instituição, mesmo que subsidiariamente, nessa área. ${ }^{156}$ No caso de ação civil pública, requer-se que o interesse tutelado tenha relevância social, sobretudo em se tratando de interesses individuais homogêneos $^{157}$.

A assunção pelo Ministério Público da condição de autor da demanda, assim como pelos demais co-legitimados, não é obrigatória em todos os casos. Se para os legitimados dotados de natureza jurídica privada isso decorre de sua livre escolha, para o Ministério Público decorre da constatação de que há fundamentos para a continuidade da ação coletiva, de que os interesses defendidos possuem relevância suficiente, bem assim de que em comparação com outros instrumentos processuais e tutelas disponíveis, seria mais apropriado dar continuidade àquele já em curso, na fase em que se encontra, do que promover uma nova demanda. ${ }^{158}$ Lembre-se, a esse respeito, que mesmo para propor uma demanda coletiva é reconhecida certa autonomia para o membro do Ministério Público, prevendo-se a possibilidade de promover o arquivamento de inquérito civil, mediante

\footnotetext{
${ }^{156}$ COSTA, 2009, pp. 223/224.

${ }^{157}$ LEONEL, 2011, p. 183.

${ }^{158}$ Para Susana Henriques da Costa, "o membro do Ministério Público deverá verificar que no caso concreto há fundamento de fato e de direito na demanda a justificar a sua intervenção. Se entender que se trata de demanda temerária ou mesmo que o interesse tratado não é relevante o suficientes, poderá o Parquet declinar da substituição prevista em lei." (COSTA, 2009, p. 225). De acordo com Ricardo de Barros Leonel: "A avaliação a ser feita pelo órgão do Ministério Púlico é a mesma que faria, hipoteticamente, se estivesse diante da decisão de propor ou não a ação. Há um poder-dever de agir, pois a atuação do Parquet, em razão do interesse público, está fundada no princípio da obrigatoriedade e não da disponibilidade. Todavia, não significa dever a instituição propor toda e qualquer ação, tampouco assumir a titularidade de ações que foram mal propostas, sem fundamento ou temerárias." (LEONEL, 2011, p. 193).
} 
homologação do Conselho Superior do Ministério Público, por concluir que não se trata de caso que reúna os elementos que legitimem a atuação do órgão em juízo.

Há quem entenda que a legitimidade do Parquet para a defesa de interesses metaindividuais seria ordinária, eis que corresponderia a uma sua atribuição de índole, inclusive constitucional. Desse modo, ao proceder nessa seara, a instituição estaria a agir no cumprimento de seu próprio dever e interesse, de forma que a sua presença em juízo não decorreria de um direito alheio.

Entretanto, não há como se negar que o interesse material a que busca o Ministério Público pertence a uma coletividade, e não à própria instituição. Conforme esclarece Susana Henriques da Costa, trata-se "da defesa de interesse alheio em nome próprio, ou seja, verdadeira hipótese de legitimidade extraordinária autônoma" ${ }^{159}$. Encontrar-se a defesa de tais interesses no rol de suas atribuições não teria o condão de transformar a natureza da sua legitimidade processual, servindo apenas como forma de conferir ao Ministério Público a legitimidade adequada para agir em prol dos interesses metaindividuais ${ }^{160}$. Constituindo um de seus deveres-poderes, cria-se uma presunção de que atuará o Ministério Público adequadamente na representação da coletividade em questão.

Fato é que, no tocante a ações civis públicas, desde os seus primórdios, dentre os colegitimados a promovê-las, tem o Ministério Público se destacado como o mais atuante ${ }^{161}$. Nada obstante, críticas despontavam, especialmente em parte da doutrina italiana a respeito da utilidade prática de se atribuir a defesa dos interesses metaindividuais a entidades públicas, tanto em razão de não se tratar de atribuição a elas tradicionalmente designadas, bem assim porque se pretendia valorizar a atuação das instituições privadas, como um mecanismo de atuação da sociedade em favor dos seus próprios interesses, muitas vezes violados pelo próprio Estado. ${ }^{162}$

Com a Lei 11.448/2007, o rol dos legitimados para a propositura de ação civil pública previsto no artigo $5^{\circ}$ da Lei 7.347/85 passou a contar com a Defensoria Pública, a qual, tem

\footnotetext{
${ }^{159}$ COSTA, 2009, p. 208.

${ }^{160}$ COSTA, 2009, p. 208.

${ }^{161}$ BARBOSA MOREIRA, José Carlos. La iniciativa en la defensa judicial de los intereses difusos y colectivos: (un aspecto de la experiencia brasileña). In Temas de Direito Processual: Quinta série. São Paulo: Saraiva, 1994, pp. 165/166.

${ }^{162}$ BARBOSA MOREIRA, 1994, p 165.
} 
por função constitucional "a orientação jurídica e a defesa, em todos os graus, dos necessitados, na forma do art. 5. ${ }^{\circ}$ LXXIV" da Constituição de 1988. Por mais que essa inclusão tenha gerado manifestações propugnando por sua inconstitucionalidade, motivando inclusive o ajuizamento de ação direita de inconstitucionalidade ${ }^{163}$, ainda pendente de julgamento no Supremo Tribunal Federal, fato é que prevalece na doutrina o entendimento de que a lei é constitucional, sobretudo se observada a pertinência temática na atuação da Defensoria Pública nessa seara. Desse modo, há de se admitir ações civis públicas propostas pela Defensoria Pública para tratar de interesses metaindividuais pertinentes à defesa judicial de necessitados, entendidos como aqueles que comprovadamente sejam desprovidos de recursos. ${ }^{164}$ Nesses casos, atuará a instituição em nome próprio e não na condição de representante técnico da parte.

A União, os Estados, o Distrito Federal e os Municípios possuem legitimidade para ajuizar tanto ação civil pública, quanto ação de improbidade administrativa, mesmo porque, conforme visto, os interesses metaindividuais constituem expressão do interesse público, que sempre deve ser perseguido e defendido pelo Estado ${ }^{165}$.

É preciso, entretanto, que haja correspondência entre a pessoa jurídica demandante e a relação jurídica de direito material subjacente à ação. A esse respeito, é expressa a lei de improbidade administrativa ao restringir a legitimação à pessoa jurídica lesada. Nada obstante inexistir dispositivo correspondente na legislação regulamentadora da ação civil pública, a mesma correlação se faz necessária, em razão da pertinência temática e da restrição da atuação de tais entes ao exercício de suas atribuições constitucionais e legais.

Sustenta-se que a legitimidade de aludidos entes públicos pode se apresentar de duas formas: caso a ação proposta tenha por objeto a defesa do patrimônio público, seria sua legitimidade ordinária, de outro modo, referindo-se o objeto a outros interesses metaindividuais, configuraria-se legitimidade extraordinária. Isso porque a defesa do patrimônio público constituiria interesse secundário pertencente ao próprio ente público, de

\footnotetext{
163 ADIn 3.943.

${ }^{164}$ LEONEL, 2011, 198.

${ }^{165}$ Da mesma forma que o Ministério Público, reconhece-se a diversos outros órgãos públicos legitimidade para a promoção de outros instrumentos públicos, incluindo os referentes ao controle concentrado de constitucionalidade e revisão ou cancelamento de súmula vinculante.
} 
modo que nesse caso estaria a agir em juízo para a tutela do seu próprio patrimônio ${ }^{166}$. No entanto, vale ressaltar que tal entendimento é questionável. Apesar de se reconhecer a existência de um interesse secundário, lembre-se que sua perseguição por qualquer ente público somente se autoriza na medida em que coincida com o interesse público primário. A possibilidade da entidade pública optar por figurar no polo passivo da ação de improbidade administrativa, por exemplo, não indica a dissociação do interesse primário do secundário, pois pressupõe o entendimento do ente público de que não houve lesão ao interesse público no caso. Desse modo, o que de fato sempre a entidade pública busca tutelar é o próprio interesse público primário. Assim, a correspondência com o interesse secundário não seria forma de garantir legitimação ordinária para o ente público, mas apenas critério para assegurar sua pertinência temática e representatividade adequada.

O artigo 82, inciso III, do Código de Defesa do Consumidor admite também que entes públicos despersonalizados promovam ação civil pública, representando uma exceção ao princípio de que para se pleitear em juízo se faz necessária a personalidade jurídica. Aqui também se exige a pertinência temática. Não se reconhece a legitimidade de aludidos entes para o ajuizamento de ação popular ou de ação de improbidade, de modo que não podem perseguir a tutela de interesses gerais, mas somente interesses difusos, coletivos ou individuais homogêneos ${ }^{167}$.

Às associações se reconhece legitimidade extraordinária para a tutela de interesses metaindividuais por meio de diversos mecanismos, tais como ação civil pública (artigo $5^{\circ}$, inciso V da Lei 7.347/1985 e artigo 82, inciso IV do Código de Defesa do Consumidor) e mandado de segurança coletivo (artigo 5º inciso LXX, da Constituição da República e artigo 21 da Lei 12.016/2009) ${ }^{168}$.

Funcionam as associações como um meio indireto de participação dos indivíduos na tutela dos interesses metaindividuais nos casos outros que não os da ação popular. No Estado

\footnotetext{
166 "No caso em tela, o nexo existente entre a relação jurídica de direito material não é de afinidade, ou mesmo de pertinência entre os objetivos dos entes legitimados e o bem objeto do processo. Ao contrário, há uma relação de titularidade entre interesse lesado e os entes estatais, que os legitima a tutelar o patrimônio público" (COSTA, 2009, p. 230).

${ }_{167}$ COSTA, 2009, p. 238.

${ }^{168}$ Vale lembrar, outrossim, que algumas espécies associativas são legitimadas a propor ações de controle concentrado de constitucionalidade (artigo 103 da Constituição da República e artigo $2^{\circ}$, inciso I da Lei 9.882/1999), bem como a requerer a aprovação, revisão ou cancelamento de súmula vinculante (artigo 103-A da Constituição da República).
} 
Democrático de Direito, estimula-se a reunião dos membros da sociedade em entes associativos, formando corpos intermediários entre as esferas pública e privada. Representam tais entidades veículos mais eficientes de defesa dos interesses de grupos, eis que congregam recursos e esforços de seus membros em vista dos interesses comuns. Também decorre desta organização maior peso político para coletividade representada, sobretudo em comparação com agrupamentos dispersos e sem união de seus membros.

Para garantir a representatividade adequada da associação, impõe a lei como requisito de legitimidade a pré-existência do ente associativo por período mínimo de um ano, bem assim que o interesse defendido em juízo faça parte de suas atribuições institucionais. Pode o juiz, entretanto, em vista das circunstâncias do caso concreto, dispensar o requisito da pré-constituição. Mesmo sem previsão legal expressa, reconhece-se ao juiz o poder de perquirir a efetiva capacidade da associação de desempenhar adequadamente a representação desses interesses, de modo a que possa afastar a legitimidade caso, por exemplo, entenda estar a associação agindo com manifesta má-fé ou por não possuir capacidade técnica mínima para a tutela desses interesses metaindividuais ${ }^{169}$.

A par de sua atuação como substituto processual, também podem as associações atuar como representantes processuais de seus associados, agindo em nome e por conta destes (artigo $5^{\circ}$, inciso XXI, da Constituição da República). Nesses casos, a legitimidade das associações é ordinária e estas atuarão na defesa de interesses individuais e não coletivos. Os efeitos da decisão ficarão acobertados pelo regime tradicional da coisa julgada apenas no que toca aos associados, não beneficiando ou prejudicando eventuais outros membros da mesma coletividade. Considera-se que apenas nesse caso se faz necessária a autorização assemblear e apresentação do rol dos associados para atuação em juízo nos termos do artigo $2^{\circ}$-A da Lei 9.494/1997, que trata de ações movidas em face da União, dos Estados, do Distrito Federal e dos Municípios ${ }^{170}$.

\footnotetext{
${ }^{169}$ COSTA, 2009, p. 235.

${ }^{170}$ Há de se destacar, todavia, a existência de entendimento no sentido de impor referidos requisitos também para a atuação das associações como substituto processuais da coletividade que pode superar o universo de seus membros.
} 
Nada obstante a relevância atribuída às associações como veículo de participação da sociedade civil no trato dos interesses metaindividuais ${ }^{171}$, nota-se que não se desenvolveu no Brasil uma propensão associativa significativa. Mesmo nas esferas em que despontaram organizações associativas, contudo, não se revelaram as mesmas como agentes promotores da defesa de interesses coletivos em juízo. Quando necessário, o caminho normalmente trilhado por essas entidades se resume ao recurso ao Ministério Público ${ }^{172}$.

\subsection{RELAÇÕES ENTRE DEMANDAS}

Da mesma forma que os interesses no plano material interagem, ora em relações de solidariedade ou instrumentalidade, de modo que o atendimento de um represente uma vantagem para outro, ora de conflito, se a efetivação de um importar o desatendimento do outro, também se concebem relações entre demandas submetidas ao Poder Judiciário, eis que o mesmo evento ou conjunto de fatos pode dar origem a diferentes pedidos, por vezes cumulados na mesma ação, outras vezes formulados em ações diferentes.

A conexão é fenômeno que se dá entre demandas que apresentem certo grau de sobreposição de elementos e que pode vir a autorizar a sua reunião para processamento e julgamento conjunto. Na definição clássica de Pescatore, três seriam os elementos a serem considerados para esse fim: os litigantes, o título litigioso e a coisa demandada. ${ }^{173}$ Essa conexão em razão do compartilhamento de elementos das demandas é chamada de conexão material. Ao lado dela, sob outra perspectiva, despontaria a conexão instrumental, configurando-se pela sobreposição dos instrumentos das causas, identificando-se a razão, a prova ou os bens de uma com os da outra. ${ }^{174} \mathrm{Na}$ sua essência, a conexão instrumental

\footnotetext{
171 "Na realidade, esses não são apenas legitimados para a ação coletiva. São, sim, do ponto de vista prático, os principais legitimados para a ação coletiva. Isso porque essas associações são, em geral, os entes que têm a maior capacidade de representar adequadamente os interesses postulados em juízo." (ARENHART, 2013, p. $62)$.

${ }^{172}$ BARBOSA MOREIRA, José Carlos. La iniciativa en la defensa judicial de los intereses difusos y colectivos: (un aspecto de la experiencia brasileña). In Temas de Direito Processual: Quinta série. São Paulo: Saraiva, 1994, pp 166/167. "O grande problema, porém, da atuação dessas entidades é o fato de que elas não estão suficientemente organizadas para o exercício dessa atividade. Há poucas entidades destinadas a esse fim, e muitas das que existem não estão adequadamente aparelhadas para a atuação jurisdicional. Prestam-se, no mais das vezes, para levar o problema existente ao conhecimento do Ministério Público ou de algum outro legitimado, mas não têm capacidade para, sozinhas, exercer a tutela judicial dos direitos de massa." (ARENHART, 2013, p. 64).

${ }^{173}$ COSTA, 2009, p. 265.

${ }^{174}$ COSTA, 2009, p. 265.
} 
expressa casos em que se justifique a formação da convicção do juiz de maneira unificada, razão pela qual exige o julgamento conjunto das causas.

O Código de Processo Civil determina caracterizar-se a conexão de ações nos casos em que lhes são comuns os objetos ou as causas de pedir, deixando de se referir à hipótese de conexão subjetiva, de sobreposição das partes. A interpretação que se faz do artigo 103, o qual veicula tal norma, é, entretanto, ampliativa, sobretudo em vista de uma concepção mais alargada de conexão adotada em outros artigos. Assim, entende-se não ser necessária a identidade perfeita entre as causas de pedir, por exemplo, para que duas causas sejam conexas. Suficiente se faz a identidade parcial, desde que no caso tenha o juiz que formar convicção única a respeito os fundamentos de todas as demandas propostas.

Observando essa tendência interpretativa, Susana Henriques da Costa indica ter o sistema processual brasileiro adotado a conexão sob a forma instrumental, causando o processamento e julgamento conjunto de demandas de modo a levar o juiz a formular seu convencimento a respeito das questões trazidas em ambas de forma unificada, por razões de economia processual e consistência dos julgados, em razão de um elo de ligação mínimo existente entre as causas ${ }^{175}$.

O fenômeno da continência se assemelha ao da conexão, recebendo o mesmo tratamento pelo Código de Processo Civil. Verifica-se a continência entre demandas nos casos em que ambas possuem a mesma causa de pedir, as mesmas partes e o pedido formulado em uma a demanda-contida - está incluído no objeto mais amplo da outra - a demanda-continente.

Em casos de conexão ou continência determina a norma processual que as causas sejam reunidas para processamento e julgamento conjunto no mesmo juízo. Algumas restrições se impõem, todavia. Como a medida causará a modificação da competência para o julgamento da causa movida, não poderá ser implementada caso se trate de competência absoluta, não sujeita a derrogação. Da mesma forma, não proporcionará a reunião dos processos caso um deles se encontre em estágio avançado ou já tenha sido julgado em primeira instância, porquanto nesses casos, além de não se causar qualquer economia processual, prejudicar-se-ia o andamento do processo mais adiantado. Não se configurando

${ }^{175}$ COSTA, 2009, p. 267. 
nenhuma dessas hipóteses, decorre o dever do juiz de reunir as causas, tratando-se de norma cogente baseada em razões de ordem pública relacionadas à efetividade do processo e à prevenção de decisões contraditórias ${ }^{176}$.

Relações de conexão e continência não são exclusivas ao universo das ações individuais, também se observando entre ações coletivas, bem assim entre ações coletivas e individuais. Com certa frequência, eventos que impactem interesses metaindividuais o fazem atingindo mais de uma categoria de interesses, trazendo efeitos para interesses difusos, coletivos e individuais, tornando-se centro de irradiação de demandas. Lembre-se, ademais, a conflituosidade ínsita aos interesses difusos, que os leva a constantemente encontrarem-se em tensão com outros interesses metaindividuais e individuais, motivando o ingresso de demandas por indivíduos e entes representando cada um dos interesses em conflito.

A formação do convencimento judicial e a prolação de decisões unificadas revelam-se ainda mais relevantes nos casos envolvendo ações coletivas em razão da indivisibilidade dos interesses metaindividuais, bem assim da pluralidade de interesses em conflito não raro existente. O que se evita, assim, não é o mero conflito lógico de julgados, e sim o conflito prático capaz de gerar o total descrédito no Poder Judiciário.

O regramento do fenômeno para demandas coletivas apresenta algumas diferenças. Enquanto entre ações individuais considera-se competente para julgar ações conexas o juízo que primeiro despachar a petição inicial, casos se trate de ações promovidas perante diferentes juízos na mesma comarca, ou aquele em que se efetuar a citação em primeiro lugar, caso se esteja diante de processos em trâmite em comarcas diferentes, nos casos de ações coletivas será prevento e, dessa forma, competente sempre o juízo em que for proposta a primeira ação ${ }^{177}$.

Ademais, apesar da competência territorial ser considerada de natureza absoluta na esfera coletiva, o que impediria a sua derrogação para a reunião dos processos em outro foro, considera-se precedente a norma que impõe aludida reunião, em vista do papel que desempenha para evitar decisões incompatíveis na prática. Também há quem considere que

\footnotetext{
${ }^{176}$ Ressalve-se, entretanto, a existência de entendimento diverso, conforme reportado por Susana Henriques da Costa, segundo o qual a decisão de reunir as causas constitui mera faculdade do juiz. (COSTA, 2009, p. 268).

${ }^{177}$ COSTA, 2009, pp. 274/275.
} 
o fato de uma das demandas encontrar-se em estágio mais adiantado ou já tiver sido julgada em primeira instância não deve ser capaz de impedir o envio da segunda demanda para julgamento pelo mesmo juízo da primeira, pois terá este se tornado competente por força da prevenção ${ }^{178}$.

Os efeitos da conexão ou da continência entre ação coletiva e individual devem ser apurados em vista do caráter instrumental da reunião dos processos, ou seja, determinando se os fins a que se destina poderão ser alcançados, sem que se sacrifiquem valores e princípios de igual estatura. Assim, por exemplo, em caso de proliferação de ações individuais a números de vultosa grandeza, a reunião poderia implicar a inviabilidade do gerenciamento de todas as causas por um mesmo juízo, em razão do elevado número de demandantes e das questões particulares por eles trazidas. Nesses casos, defende Ricardo de Barros Leonel não sejam aplicados os efeitos da conexão e da continência ${ }^{179}$.

Para além dos casos de conexão e continência, prevê o sistema a possibilidade das ações manejadas reproduzirem todos os seus elementos: partes, causa de pedir e pedido. A esse respeito, um de dois fenômenos (litispendência e coisa julgada) podem despontar e gerar consequências, um se ambas as demandas tiverem curso simultaneamente e o outro se uma demanda suceder outra já finda.

O termo litispendência indica a pendência da lide, ou seja, a existência de um processo em curso. Nada obstante o seu início se dê com a propositura da demanda pelo autor, o efeito só atingirá o réu com a citação, de modo que a relação jurídica processual até então estabelecida de forma bilateral entre o autor e o juiz torne-se tríplice com a inclusão do réu. Estabelecida a litispendência, vinculando o réu a partir de sua citação, nos termos do artigo 219 do Código de Processo Civil, o seu efeito será a vedação ao processamento e julgamento de mérito de outra demanda que reproduza os seus elementos. Em outras palavras, a mesma ação não poderá ter curso em dois processos simultaneamente, devendo

\footnotetext{
${ }^{178}$ COSTA, 2009, 272/275

179 (LEONEL, 2011, p. 271). Ada Pellegrini Grinover, considerando ação coletiva proposta para a tutela de direito individual homogêneo, entendia que no caso da propositura de demandas individuais com objeto abrangido na demanda coletiva, deveriam as demandas individuais ser reunidas para julgamento conjunto com a coletiva. Entretanto, mudou de posicionamento para sustentar que tal reunião poderia se tornar um entrave para a efetividade da justiça, muitas vezes prejudicando o processamento da ação coletiva, em razão da multiplicação de ações individuais e dos diferentes estágios em que os processos podem se encontrar. Assim, a solução propugnada seria a suspensão das demandas individuais enquanto estiver em curso a coletiva. (GRINOVER, 2011, p. 215).
} 
a segunda ser extinta sem resolução de mérito, nos termos do artigo 267 , inciso V, do Código de Processo Civil.

Fenômeno diverso, mas com os mesmos efeitos se dá se a ação reproduzida for proposta após o término do primeiro processo caso neste tenha se formado coisa julgada material. Chama-se de coisa julgada a imutabilidade que recai sobre a sentença ou decisão que venha a substituí-la ao tornar-se irrecorrível. Trata-se de uma forma de preclusão, a chamada preclusão máxima ou preclusão definitiva nas palavras de Giuseppe Chiovenda, por conta da qual se encerra qualquer possibilidade de rediscussão das questões postas naquele processo. Nesse tocante, vale notar a diferença entre o conteúdo da sentença, os seus efeitos e a imutabilidade do seu comando.

A norma concreta é o conteúdo essencial de uma sentença, seja ela constitutiva, declaratória ou condenatória. Do conteúdo da sentença difere a sua eficácia, entendida como o conjunto dos efeitos produzidos por uma sentença, tanto efetivos quanto potenciais. Enquanto o conteúdo encerra-se no plano interno ao ato, os efeitos são sua projeção para a esfera externa, ressalvando-se que os últimos obviamente se produzirão em conformidade com as definições do primeiro. A relação entre conteúdo e efeitos da sentença, contudo, não é de causalidade natural, de forma a não bastar a formação do primeiro para que por si só seus efeitos se produzam no mundo do direito. É a lei o fundamento de eficácia da sentença, cabendo àquela atribuir a esta seus efeitos, podendo, inclusive, modificá-los. Refere-se, a esse respeito, aos efeitos jurídicos, sem prejuízo de outros efeitos estritamente no mundo dos fatos, como, por exemplo, o contentamento de um litigante e a tristeza do outro, constituindo aquilo a que se alude como eficácia natural da sentença ${ }^{180}$.

A eficácia da sentença também não se confunde com a eventual imutabilidade da norma concreta por ela carreada. Aludida imutabilidade, aliás, sequer é imprescindível sob a perspectiva estritamente jurídica. Seus parâmetros e hipóteses de incidência são postos em função de critérios de política legislativa. ${ }^{181}$ Reconhecer a imutabilidade importa não

180 BARBOSA MOREIRA, José Carlos. Notas sobre o Problema da "Efetividade do Processo". In: Temas de Direito Processual: terceira série. 1. ed. Saraiva: São Paulo, 1984, p. 105.

181 Noticia José Carlos Barbosa Moreira a existência na história do direito de casos de mutabilidade permanente, por mais que de foma excepcional. (BARBOSA MOREIRA, José Carlos. Notas sobre el 
admitir a rediscussão da matéria submetida ao juiz no mesmo processo, ao que se denomina o efeito da coisa julgada formal, ou, além disso, a impossibilidade de se questionar a norma concreta advinda do processo, como decorrência da coisa julgada material.

Nesse tocante, nota-se que a imutabilidade não recai sobre os efeitos da sentença, como se pode observar na prática, por exemplo, no caso em que um casal divorciado restabelece o vínculo conjugal por um novo casamento. Ademais, a imutabilidade da norma concreta contida na sentença fica vinculada à situação existente no momento da prolação da sentença, de modo a não se vedar novo processo e novo comando concreto com relação a modificações ocorridas em tal situação. Admite-se, assim, a coexistência de mais de uma norma concreta, muito embora se refiram a situações jurídicas diversas: uma referente a situação relegada ao passado e outra alusiva à situação que tenha a sucedido ${ }^{182}$.

Assim, a definitividade da decisão produzindo efeitos internos ao processo, a coisa julgada formal, opera-se independentemente do conteúdo decisório, ou seja, mesmo se proferida sentença de mérito ou terminativa. Nos casos em que há julgamento definitivo de mérito, além desse efeito endoprocessual decorrente da coisa julgada formal, a sentença também ficará acobertada pela coisa julgada material de forma que o seu conteúdo decisório, especificamente aquele que constar do seu dispositivo, tornar-se-á imutável. Considera-se sentença de mérito aquela em que houver exame do objeto do processo resultando em um provimento com efeitos extraprocessuais, atingindo as partes em sua esfera jurídica. São justamente esses efeitos da sentença e o comando dela proveniente que se tornam imutáveis, não sendo passíveis de rediscussão em nova ação entre as mesmas partes.

Isso importa dizer que uma vez formada a coisa julgada material, não poderá demanda idêntica ser proposta, devendo a mesma restar extinta sem resolução de mérito nos termos do artigo 267, inciso V, do Código de Processo Civil. Vale ressaltar, entretanto, que uma segunda demanda será admitida se no primeiro processo formar-se apenas a coisa julgada formal, já que, conforme supra explanado, esta produzirá efeitos tão somente no processo em que proferida a sentença.

contenido, los efectos y la imutabilidad de la sentencia. In Temas de Direito Processual: Quinta série. São Paulo: Saraiva, 1994, p. 106).

${ }_{182}$ BARBOSA MOREIRA, José Carlos. Notas sobre o Problema da "Efetividade do Processo". In: Temas de Direito Processual: terceira série. 1. ed. Saraiva: São Paulo, 1984, p. 107. 
Tanto a litispendência quanto a coisa julgada material para provocarem a extinção da segunda demanda dependem da igualdade dos três elementos identificadores da ação, os chamados tria eadem. Assim, embora a litispendência e a coisa julgada existam independentemente de qualquer outro processo, a relevância de ambos os fenômenos exsurge mediante a pendência de uma segunda ação que reproduza a primeira. Daí resultar certa confusão, inclusive na linguagem utilizada no Código de Processo Civil, entre a constatação da litispendência ou da coisa julgada material e a aplicação de seus efeitos para extinguir o segundo processo, razão pela qual se tornou corriqueiro o emprego desses termos para, na verdade, designar os seus efeitos.

Se tradicionalmente a constatação da existência de duas demandas com os mesmos elementos não representa tarefa de maior dificuldade, ao menos duas questões surgem no trato de demandas coletivas. Em primeiro lugar, podem-se configurar os fenômenos mesmo se as partes nos dois processos não sejam nominalmente as mesmas. Isso porque o ente a figurar no processo como defensor do interesse metaindividual não é, de fato, o titular de aludido interesse. Pela técnica da substituição processual, comparece em juízo para defender em nome próprio direito alheio. Portanto, quem deve ser considerada parte para fins de apuração da litispendência e coisa julgada é a coletividade a que pertence o interesse em questão. Trata-se, da "parte ideológica".

Em segundo lugar, o fato de se terem atribuído nomes diferentes para as demandas não impede que contenham os mesmos elemento, podendo ensejar os efeitos da litispendência ou da coisa julgada. Na medida em que a causa de pedir, o pedido e a coletividade titular do interesse defendido sejam os mesmos, verificar-se-ão os efeitos da litispendência ou da coisa julgada entre uma ação popular e uma ação coletiva, por exemplo.

O zelo pelos autores individuais levou o legislador a eliminar a possibilidade dos efeitos da litispendência de uma ação coletiva em que se busque a tutela de interesses coletivos sobre demandas individuais, conforme artigo 104 do Código de Defesa do Consumidor. Assim, mesmo que uma pretensão individual já esteja albergada pela demanda coletiva, permite-se ao autor individual propor sua própria ação, que se desenvolverá em paralelo ao processo coletivo. Certo é que, entretanto, sob o pressuposto de que o autor individual estará buscando a tutela apenas do seu interesse individual, por mais que relacionado a um 
interesse metaindividual, a relação da sua demanda com a coletiva seria de continência e não de "litispendência". Por esse motivo é que não decorre prejuízo da falta de previsão legal expressa a respeito da relação entre demanda individual e demanda coletiva tendo por objeto a tutela de interesses individuais homogêneos que compreendam aquele que se busca na primeira ${ }^{183}$.

No que toca à coisa julgada material, as diferenças entre os regimes das ações individuais e ações coletivas são sensíveis. Via de regra, impõem-se limites objetivos e subjetivos à coisa julgada. Sob o aspecto objetivo, fica a coisa julgada limitada ao dispositivo da sentença, admitindo-se a rediscussão em um segundo processo das questões de fato e de direito pertinentes à fundamentação da decisão. Subjetivamente, a coisa julgada atinge unicamente as partes do processo sem prejudicar ou beneficiar terceiros conforme a disciplina do artigo 472 do Código de Processo Civil. A limitação subjetiva da coisa julgada não impede que os efeitos da sentença atinjam terceiros que não tenham participado do processo, mas permite que o conteúdo da decisão seja por eles discutido em outro processo. Os efeitos produzidos pela sentença e a mutabilidade do comando nela contido são fenômenos diversos.

Exceções são previstas para a regra da limitação subjetiva da coisa julgada, de modo que também perante terceiros assumam os efeitos da sentença caráter de imutabilidade. Essas hipóteses, muito embora possam representar uma limitação ao contraditório, justificam-se sob a perspectiva do acesso à justiça.

Menciona-se, a esse respeito, casos de litisconsórcio ativo unitário facultativo nos quais o objeto da demanda se refira a situação jurídica substancial única e incindível, de modo que havendo uma pluralidade de sujeitos ocupando a mesma posição em referida situação, sentença que venha a ser proferida na demanda promovida por qualquer um deles necessariamente produza efeitos com relação a todos os demais. Hipóteses desse jaez, na realidade, configurariam casos de litisconsórcio ativo necessário, de modo a exigir a participação de todos os sujeitos no polo ativo da demanda, em atendimento, inclusive, aos

\footnotetext{
183 Ricardo de Barros Leonel entende que sequer continência poderia se verificar porque os pedidos formulados em ambas as demandas terão natureza diversa. Enquanto na demanda coletiva o pleito se refere à condenação genérica, na individual é específica para o caso do autor. Mesmo se procedente a demanda coletiva, o autor individual ainda teria que provar o nexo de causalidade e o dano experimentado na liquidação individual. (LEONEL, 2011, p. 271).
} 
ditames do contraditório. Ao permitir-se que um deles aja isoladamente, reconhece-se que tal exigência configuraria óbice severo ao exercício do direito de ação do demandante, especialmente em razão de casos em que a quantidade dos indivíduos a ocuparem essa sua mesma posição seja alta ou configurem um grupo cuja identidade dos componentes seja de difícil determinação. Privilegia-se, desse modo, o exercício do direito subjetivo do demandante, estendendo-se os efeitos da coisa julgada aos demais sujeitos de forma a se garantir segurança jurídica.

Em razão da indivisibilidade que marca os interesses difusos e coletivos, a sentença de mérito proferida em processo no qual se busca a sua tutela produzirá efeitos com relação a toda a coletividade titular do interesse. Nas ações coletivas, entende-se que tal coletividade está representada por meio de seu substituto processual, de modo a que seja natural que a todos os seus membros recaiam os efeitos da coisa julgada. Se aludidas ações versarem sobre interesses individuais homogêneos, embora seja de objeto divisível, o seu tratamento se dá de forma coletiva, assumindo, dessa forma, contornos de indivisibilidade. Apesar disso, há quem entenda que as hipóteses de demandas coletivas que a coisa julgada gere efeitos além das partes representem hipóteses de extensão subjetiva desses efeitos.

Susana Henriques da Costa afirma que os casos envolvendo interesse geral, por não produzirem efeitos direitos e pessoais com relação a sujeitos específicos, não ensejam a extensão subjetiva dos efeitos da coisa julgada. À esfera individual será juridicamente irrelevante o conteúdo da decisão, não o beneficiando ou o prejudicando independentemente do resultado.

Segundo a disciplina do Código de Defesa do Consumidor, no seu artigo 103, tratando-se de interesses difusos ou individuais homogêneos, poderá a coisa julgada ter efeito erga omnes, e, se forem interesses coletivos, efeitos ultra partes. Vale ressaltar que a mera extensão da coisa julgada para partes que não estejam nominalmente incluídas em um dos polos da relação jurídica processual não importa extensão a todo e qualquer sujeito que não tenha participado do processo. Não é incomum que interesses metaindividuais se encontrem em choque com outros interesses em um caso concreto. Por mais que de um processo resulte uma decisão que beneficie um interesse metaindividual, aproveitando a coisa julgada a todos os membros da coletividade beneficiada, não poderá formar coisa 
julgada com efeitos vinculantes a titulares de outros interesses contrapostos que não tenham participado, sido representados ou substituídos no processo.

Ademais, a disciplina adotada pelo Código de Defesa do Consumidor contempla o fenômeno da coisa julgada secundum eventum litis e secundum probationem. Isso importa dizer que os efeitos da coisa julgada variarão em conformidade com o resultado da demanda e da prova produzida. Sendo a sentença favorável ao interesse metaindividual, a coisa julgada se estenderá para favorecer toda a coletividade em questão. No entanto, se desfavorável for, mas o resultado derivar da ausência de provas, não se formará coisa julgada coletiva, autorizando-se a repropositura da demanda coletiva desde que suportada por nova prova.

Trata-se de uma opção política do legislador para beneficiar o interesse coletivo em detrimento da segurança jurídica em virtude da natureza pública atribuída a interesses dessa espécie. Ponderando-se a respeito dos valores em conflito, maior importância foi atribuída à preservação do interesse coletivo do que à imutabilidade da sentença. Considera-se, assim, que em casos de incerteza decorrentes de insuficiência probatória, pela importância dos interesses envolvidos, há de se permitir que o conteúdo decisório e os seus efeitos venham a ser questionados em uma nova demanda coletiva. Também se funda essa regra na limitação ao controle judicial da representatividade adequada do substituto processual da coletividade no direito processual brasileiro. Como inexistem mecanismos para determinar que o ente legítimo de fato representa a coletividade em questão, mitigamse os efeitos negativos que a sua atuação pode vir a causar para o grupo.

Adicionalmente, em qualquer hipótese de improcedência, o resultado da ação não prejudicará demandas individuais. Isso porque aludidas demandas, em tese, não servem para a tutela de interesses metaindividuais. Assim, os seus elementos não se confundem com os de uma demanda coletiva. Não serão os mesmos o pedido, a causa de pedir e as partes do processo. Ressalte-se, entretanto, que o mesmo evento pode causar repercussões tanto na esfera coletiva como na individual de forma que venha a figurar na causa de pedir de demandas de ambas as naturezas. Isso não acarreta a identidade das ações. A esse respeito, ainda, nota-se que a disciplina legal adotada no Código de Defesa do Consumidor expressamente determina que os efeitos negativos de uma ação coletiva não prejudicarão 
demandas individuais, ao que se dá mero caráter didático, eis que tal efeito já decorre da própria falta de identidade entre as demandas ${ }^{184}$.

Essa disciplina legal, todavia, mostra-se essencial no que toca às ações coletivas que tenham por objeto interesses individuais homogêneos. Isso porque aludidas ações nada mais representam que o tratamento processual coletivo de demandas individuais, ou seja, no seu objeto encontram-se interesses materialmente individuais, acidentalmente coletivos. Por decorrência, os elementos de uma ação coletiva, nesse caso, podem guardar uma relação de equivalência com os elementos de demandas individuais, de forma que a estas se aplicaria o regime geral da coisa julgada material. Consideram-se substituídos na ação coletiva todos os titulares de interesses individuais homogêneos. Logo, haveria uma relação de continência entre uma demanda coletiva e a individual, em virtude da identidade de pedido e causa de pedir, bem assim das partes, já que o réu será o mesmo e o autor da demanda individual estará incluído no rol dos substituídos da ação coletiva ${ }^{185}$.

Em todos os casos de improcedência da ação coletiva que não seja fundada em insuficiência probatória, não há prejuízo para demandas individuais, mas não se admite a repropositura de nova demanda coletiva.

Como em geral esses indivíduos não participam diretamente da demanda coletiva, preocupou-se o legislador em fazer com que eventual desfecho negativo do processo coletivo não os impeça de perseguir a tutela de seus direitos subjetivos por meio da propositura de demandas individuais. Por isso é que só haverá efetivo tratamento coletivo dos interesses individuais no caso de procedência da ação coletiva, seja ela referente a direitos difusos, coletivos em sentido estrito ou individuais homogêneos. Nos demais casos (de improcedência ou de decisão terminativa) será permitido aos interessados ingressarem com ações individuais, não sendo diretamente prejudicados pelo resultado da ação coletiva. Os defensores dessa forma de tratamento associam-na ao direito constitucional de ação e à

\footnotetext{
184 "Ainda que não houvesse o dispositivo mencionado, a improcedência da demanda coletiva tratando de interesses difusos e coletivos, seja por ausência de provas ou não, jamais atingiria a esfera de direitos do indivíduo prejudicado no caso concreto pelos mesmos fatos, pois se tratam de situações jurídicas substanciais diversas. A suposta lesão ou ameaça de lesão ao direito difuso ou coletivo pode até mesmo advir dos mesmos fatos que a suposta lesão ou ameaça de lesão a um direito individual (causa de pedir remota). Nunca, entretanto, tratar-se-á das mesmas partes, do mesmo pedido, ou mesma fundamentação jurídica (causa de pedir próxima), tendo em vista que os interesses difusos e coletivos são metaindividuais e, portanto, possuem características e especificidades próprias." (COSTA, 2009, p. 299).

${ }^{185}$ Em sentido contrário, é o entendimento já exposto de Ricardo de Barros Leonel.
} 
garantia ao contraditório, que ficariam restringidos se os sujeitos estivessem legalmente impedidos de ajuizar suas demandas em razão de uma decisão de um processo do qual não fizeram parte.

Outra peculiaridade se apresenta no regime jurídico da coisa julgada proveniente de ações coletivas. Trata-se do fenômeno da ampliação dos limites objetivos em sede de ação civil pública. Prevê o Código de Defesa do Consumidor no seu artigo 103, § $3^{\circ}$, que nos casos de procedência de ação civil pública alusivo a interesses difusos ou coletivos, os efeitos da sentença beneficiarão as vítimas individualmente. Nesse caso, constata-se que a tutela dos interesses individuais dessas vítimas não fazia parte do objeto da demanda coletiva. Há quem entenda que nesse caso ocorre uma ampliação ope legis do objeto do processo, que desse modo, passando a abarcar a condenação do réu ao pagamento de indenização concernente às perdas e danos resultantes dos mesmos fatos. Entretanto, não parece haver de fato uma modificação no objeto do processo, seja ela de redução ou de ampliação, eis que este resta fixado no momento da propositura do pedido, não se sujeitando a modificações após a decisão de saneamento.

Defende-se a esse respeito que em termos jurídicos a regra do Código de Defesa do Consumidor signifique a extensão dos limites objetivos da coisa julgada de forma a tornar imutável não somente o provimento relacionado aos interesses metaindividuais envolvidos, como também o reconhecimento da ocorrência do evento danoso e da responsabilidade do demandado. Desse modo, aproveitando-se desses efeitos, ficarão os autores individuais dispensados de demonstrar e comprovar tais fatos e suas consequências jurídicas, nele podendo se embasar para promover a liquidação de sua indenização. Ressalve-se que ainda será possível discutir a extensão do dano sofrido individualmente, por consequência do ato lesivo.

A poluição que infringe o interesse difuso ao meio ambiente equilibrado pode provocar danos individuais aos vizinhos do agente poluidor, aos quais assiste o direito à indenização pelos gastos médicos incorridos e por todas as demais perdas e danos experimentados por decorrência da poluição lançada. A sentença da ação coletiva que reconhece que uma fábrica efetuou o lançamento indevido de poluentes capazes de gerar certos malefícios à saúde humana, condenando tal fábrica a abster-se de efetuar novos lançamentos e a recompor o meio ambiente degradado, estará tutelando o interesse difuso ao meio ambiente 
equilibrado. O vizinho vítima da poluição poderá se beneficiar de aludida sentença transitada em julgado de forma a utilizá-la como base para sua demanda individual indenizatória comprovando apenas o prejuízo que lhe foi causado e o nexo de causalidade com o ato ilícito praticado pelo agente poluidor. Ao se dispensar um novo processo de conhecimento para se apurar a conduta ilícita e lesiva da fábrica para os fins de amparar a imposição do pagamento de indenização em favor da vítima individual da poluição, também se estará dando tratamento coletivo a um interesse individual. Seria como se todas as pretensões individuais reparatórias das vítimas estivessem de alguma forma inseridas no objeto da demanda coletiva precedente.

É de se notar que, de fato, esses indivíduos poderão se beneficiar duplamente da sentença coletiva. Além de poderem utilizá-la como título para sua demanda indenizatória, como membros da coletividade titular do interesse coletivo também se beneficiarão da própria tutela coletiva. Na medida em que o agente poluidor venha a cumprir a decisão e deixe de poluir, evitar-se-ão novos prejuízos aos vizinhos afetados. 


\section{CAPÍTULO 2. A PATOLÓGICA MULTIPLICAÇÃO DE DEMANDAS INDIVIDUAIS}

\subsection{PROLIFERAÇÃO DE PROCESSOS INDIVIDUAIS NO ÂMBITO COLETIVO}

Examinadas a coletivização de demandas no plano material, por meio da juridicização dos interesses coletivos, e no plano material, por meio do desenvolvimento de demandas específicas para a tutela de aludidos interesses, bem assim para a tutela coletivizada de interesses individuais homogêneos, há de se atentar para o fenômeno da multiplicação das demandas individuais em casos de âmbito coletivo.

Aludido fenômeno apresenta-se como uma solução para um problema contemporâneo que aflige o Judiciário e preocupa tanto o legislador quanto os estudiosos do direito processual, que diz respeito à multiplicação dos processos em proporção tamanha que acaba por causar um congestionamento de demandas, prejudicando a prestação do serviço jurisdicional pelo Estado e configurando causa de inefetividade processual.

Na sociedade de massa contemporânea, as práticas e condutas tomadas pelos agentes são padronizadas e tendem a assumir larga escala. ${ }^{1}$ Por decorrência, as violações decorrentes dessas práticas e condutas também se apresentam de forma massificada, violando de forma similar uma quantidade indefinida de sujeitos. Muito embora as demandas coletivas tenham sido introduzidas considerando casos dessa estirpe, fato é que nessa realidade despontam os chamados processos de massa ou processos repetitivos, nos quais pretensões ou questões de direito idênticas se reproduzem em expressiva quantidade, tornando-se mais um elemento de congestionamento do Poder Judiciário.

Para examinar essa questão, deve-se considerar três fontes de problemas associados ao serviço jurisdicional e que levariam à sua inefetividade ${ }^{2}$ : em primeiro lugar, o plano legislativo, não provendo o legislador mecanismos aptos a resolver os conflitos adequadamente na forma e amplitude em que se apresentam; em segundo lugar, o plano

\footnotetext{
1 "Na sociedade globalizada não á lugar para o homem enquanto indivíduo isolado; ele é tragado pela rodaviva dos grandes grupos e corporações: não há mais a preocupação com as situações jurídicas individuais, o respeito ao indivíduo como tal, mas, ao contrário, indivíduos são agrupados em grandes classes ou categorias, e como tais, normatizados" (MANCUSO, 2004, p. 90).

${ }^{2}$ ARENHART, 2013, pp. 36/37.
} 
estrutural, referente à insuficiência dos recursos humanos e materiais empregados na prestação do serviço; e por fim, o plano cultural, que fundamentalmente diz respeito ao preparo dos operadores do direito para a execução de suas atividades ${ }^{3}$.

Ao se examinar os instrumentos processuais previstos na lei, note-se que no atual sistema as ações coletivas são incapazes de impedir a proliferação dos processos individuais, ainda que a questão coletiva subjacente seja objeto de demanda coletiva em andamento. O zelo pelos autores individuais levou o legislador a não prever medidas para obstacularizar a via individual em face da disponibilização da via coletiva. Assim, mesmo que uma pretensão individual já esteja albergada pela demanda coletiva, permite-se ao autor individual propor sua própria ação, que se desenvolverá em paralelo ao processo coletivo. ${ }^{4} \mathrm{~A}$ única ressalva prevista em lei diz respeito ao autor individual não poder se aproveitar dos eventuais efeitos benéficos da coisa julgada da ação coletiva caso insista no prosseguimento de sua demanda, não requerendo a sua suspensão ao tomar conhecimento da existência da ação coletiva.

Ademais, o legislador tratou de impropriamente limitar o alcance da ação civil pública, alterando a redação do artigo 16 da Lei da Ação Civil Pública por meio da Lei 9.494/97. Segundo o texto alterado, os efeitos da coisa julgada coletiva ficariam confinados aos limites da competência territorial do órgão prolator da sentença. Com isso pretendeu-se limitar os poderes do juiz e retirar relevância das ações civis públicas, ceifando-as de seu verdadeiro potencial coletivo. Por mais que vozes abalizadas se manifestassem de forma contrária à interpretação literal do dispositivo, o tratamento dado pela jurisprudência ao texto legal alterado, mesmo que enfrentando certa resistência, de fato restringiu o âmbito dos efeitos das ações civis públicas levando ao contrassenso de se permitir a multiplicação de ações coletivas idênticas em diversos estados brasileiros, inclusive versando sobre questões de âmbito nacional, no que seria efetivo caso de litispendência.

\footnotetext{
${ }^{3}$ No campo cultural, por exemplo, nota-se a falta de iniciativa dos advogados no sentido de tomarem medidas em conjunto para maximizar a defesa de seus clientes em casos comuns. Poderiam, por exemplo, unir-se para contratar especialistas técnicos ou juristas renomados de forma a produzirem material de suporte para suas demandas. Práticas como essa não são comuns em outros países, tais como os Estados Unidos.

4 Antevendo os eventuais problemas decorrentes da concomitância entre ações individuais e coletivas, Watanabe (2007, p. 156) aponta a necessidade de se investigar a natureza das ações individuais e a sua compatibilidade com as ações coletivas: "A coexistência da ação coletiva, em que uma pretensão de direito material é veiculada molecularmente, com as ações individuais que processualizam pretensões materiais atomizadas, pertinentes a cada indivíduo, exige, como requisito básico, a determinação da natureza destas últimas e a verificação da compatibilidade entre as distintas pretensões materiais, coletivas e individuais veiculadas nessas duas espécies de demandas.".
} 
No mesmo sentido, dentre outros óbices legais ou fatores de desestímulo para a via coletiva, aponta-se: a falta de parâmetros para a definição do que vem a constituir a homogeneidade dos interesses individuais homogêneos ${ }^{5}$; a falta de legitimidade do indivíduo para ajuizar demandas coletivas, não lhe restando alternativa a não ser propor demanda individual; dentre outras ${ }^{6}$.

No que toca aos recursos disponíveis, nota-se que não se revelam suficientes para fazer frente ao volume de processos existente. ${ }^{7}$ De acordo com Sérgio Cruz Arenhart:

De todo modo, os números nacionais, em si, revelam uma concentração grande de causas perante os juízes brasileiros. Revelam também uma elevada taxa de congestionamento, cuja tendência, em razão do volume de novas causas que ingressam atualmente no serviço 'justiça', é de manter-se nesses mesmos níveis ou de aumentar ${ }^{8}$.

Sustenta-se, assim, que, considerando os recursos disponíveis para a prestação do serviço, seu emprego deveria ser dimensionado em vista não apenas do processo singular que se apresenta, mas sim do total a ser demandado com relação a todos os demais casos semelhantes ajuizados ou que poderão vir a ser ajuizados. ${ }^{9}$ A utilização das ações coletivas, assim, por reduzir a quantidade do volume de processos, representa uma forma de otimizar os recursos públicos empregados na função jurisdicional, constituindo fator de eficiência.

No que toca à organização judiciária e os seus recursos, observa com precisão Kazuo Watanabe: "por mais perfeitas que sejam as leis materiais e processuais, será sempre falha

\footnotetext{
${ }^{5}$ ARENHART, 2013, p. 47.

${ }^{6}$ GRINOVER, Ada Pellegrini. Ação Civil Pública Refém do Autoritarismo. In: O processo: estudos e pareceres. 2. ed. rev. e ampl. São Paulo: DPJ Editora, 2009, pp. 290/301.

${ }^{7}$ Segundo observa José Renato Nalini, tradicionalmente os recursos postos à disposição do Judiciário são usados de forma, no mínimo, ineficiente. "Há sintomas evidentes de malversação de recursos, quando postos à disposição do Poder Judiciário. Os Tribunais não planejam, administram-se de maneira empírica, preservam estrutura arcaica e confiada a uma nomenclatura formada por servidores em nada diversos - salvo exceções honrosas e cada vez mais excepcionais - do funcionalismo dos demais poderes." (NALINI, José Renato. Ética e Justiça. São Paulo: Oliveira Mendes, 1998, pp. 163/164).

${ }^{8}$ ARENHART, 2013, p. 60

${ }^{9}$ ARENHART, 2013, p. 38.
} 
a tutela jurisdicional dos direitos, se inexistirem juízes preparados para aplicá-las e uma adequada infra-estrutura material e pessoal para lhes dar o apoio necessário" ${ }^{10}$.

Ademais, prevalece na sociedade contemporânea uma cultura individualista. Não raro tais demandas individuais sejam propostas em razão da falta de conhecimento da existência de uma ação coletiva em curso, a opção pela via individual é muitas vezes consciente e amparada em vantagens, aparentes ou reais, que tal caminho pode proporcionar ao demandante. Exemplificativamente pode-se citar a possibilidade de se obter medidas de urgência específicas, a expectativa de que a parte adversa se empenhe com menor intensidade na defesa de uma ação individual em razão da menor amplitude da potencial perda que dela possa resultar, a possibilidade do autor individual se valer de procedimentos mais simplificados, como o dos Juizados Especiais, aproveitando-se das facilidades a eles inerentes, inclusive com a expectativa de obter um resultado mais célere, o ímpeto do autor individual de ter o seu "dia na corte" e poder controlar o destino do seu caso, bem assim a influência da recomendação não tão desinteressada de advogados em busca de novos casos.

Mesmo no bojo de ações coletivas, por vezes impera a cultura individualista. Não raro a própria entidade que propõe a ação civil pública limita indevidamente o seu escopo subjetivo, formulando pedidos em benefício de grupo limitado a certa comarca ou região, não obstante o caso extrapole esses limites artificialmente impostos pelo próprio autor. ${ }^{11}$ Diante desses pleitos fica o juiz impossibilitado de julgar além - por mais que parecesse natural que o fizesse - limitado que é pelo princípio dispositivo e da congruência ${ }^{12}$.

Seja pelo uso inadequado das ações coletivas, pelas limitações a ela impostas, por incentivos dados à via individual ou mesmo pelo não cabimento de ações coletivas em razão das peculiaridades apresentadas nos casos concretos, nota-se, por vezes a multiplicação de demandas que envolvem questões de fato ou de direito comuns. Essa multiplicidade de demandas é vista como uma das causas de sobrecarga do Poder Judiciário, que, por sua vez, é um dos fatores que levam à morosidade processual, ao

\footnotetext{
${ }^{10}$ WATANABE, 1999, p. 29.

${ }^{11}$ Casos há, por exemplo, em que o órgão do Ministério Público localizado no interior, apesar de lidar com prática lesiva de repercussão regional, opta por delimitar o escopo da ação à Comarca em que se situa com o objetivo de manter-se atuante no processo, evitando que o feito seja remetido para a capital do estado em função da regra do artigo 93, inciso II, do Código de Defesa do Consumidor.

${ }^{12}$ Conforme observado abaixo.
} 
comprometimento da qualidade da atividade jurisdicional, à restrição ao acesso e à inefetividade da justiça.

\subsection{EFEITOS DA MULTIPLICAÇÃO DE DEMANDAS REPETITIVAS}

Como efeito e reação ao fenômeno observa-se em muitos casos certa coletivização de fato praticada pelos juízes, que passam a aplicar uma mesma decisão que tenham proferido em uma ação anterior aos litígios futuros que sejam submetidos ao seu julgamento e que envolvam questões semelhantes. Não só os juízes, mas também os advogados das partes não raro acabam por adotar postura semelhante, reproduzindo petições iniciais e defesas com base em modelos usados no passado. ${ }^{13}$ Em face dessa prática surge o risco do processo se tornar uma mera repetição, a reencenação de uma peça cujas falas e enredo já são conhecidos por todos. Ao se agir desse modo, categorizando as demandas sem maiores cuidados, incorre-se na possibilidade de se deixar de dar a devida atenção para questões específicas do caso em questão que poderiam levar a um desfecho diferente daquele padronizado.

Curiosamente, o efeito dessa massificação do tratamento dos litígios será uma violação velada ao contraditório, eis que os argumentos de fato e de direito apresentados pela parte não poderão influenciar a tomada de decisão do juiz, na medida em que ele empregará entendimento formado previamente.

Além do mais, o tratamento individualizado dessas demandas pode acabar por gerar decisões contraditórias ou inconsistentes, comprometendo a legitimidade do Poder Judiciário. Essa questão assume maior relevo ao se considerar as ações individuais em que a pretensão do autor está intimamente relacionada à tutela de interesse difuso ou coletivo em sentido estrito, que, como mencionado, são indivisíveis por natureza. Nesses casos, mais do que uma mera contradição lógica entre os julgados, pode se caracterizar uma contradição prática, abominada pelo sistema. No mais, daí também resulta prejuízo ao princípio da isonomia, eis que sujeitos em condições semelhantes se sujeitarão a soluções imperativas distintas impostas pelo Estado.

\footnotetext{
${ }^{13}$ Nota-se, aliás, que tal prática apresenta benefícios pecuniários para o advogado por permitir-lhe auferir ganhos de escala, utilizando o mesmo material produzido para prestar serviços para diversos clientes.
} 
Não se pode relevar o efeito que a sobrecarga de processos acarreta sobre o Judiciário, enquanto aparato estatal, e sobre o sujeito que desempenha as funções de juiz. Faz-se aqui mais uma vez referência à distinção entre interesse público, interesse do aparato estatal e interesses dos agentes públicos. O Poder Judiciário, enquanto expressão estatal, também se sujeita aos mesmos fenômenos. Por mais que sua finalidade seja exercer a função jurisdicional de modo a alcançar seus escopos sociais, políticos e jurídico, outros interesses o tocam e não devem ser desprezados, mesmo para que possam ser equacionados ou combatidos.

Por mais que o processo componha o substrato em que se exerce a função jurisdicional, a sua multiplicação vertiginosa é prejudicial a interesses do Judiciário. Quanto maior o número de processos, mais recursos são exigidos para que se cuide do seu processamento e julgamento. Não só recursos puramente materiais, como mesas, estantes, papel, computadores, prédios para a instalação de varas judiciais, como também recursos humanos, inclusive juízes, escreventes e pessoal administrativo. Medidas legítimas são adotadas na tentativa de atenuar os impactos negativos de tais exigências, como, por exemplo, a adoção do processo eletrônico. ${ }^{14}$ Medidas desse jaez, entretanto, nada obstante sejam paliativas com relação a alguns dos efeitos nocivos da multiplicação das demandas, não impedem a ocorrência do fenômeno.

Também é contrária aos interesses dos juízes, pois, em primeiro lugar, representa o aumento compulsório de sua carga de trabalho. ${ }^{15}$ Por mais que lhe assistam as garantias

\footnotetext{
${ }^{14}$ De início, apresenta os potenciais efeitos de eliminar a necessidade da manutenção de espaços para o armazenamento dos autos processuais em papel, reduzir o número de funcionários empregados em atividades mecânicas tais como a perfuração, numeração e rubrica de folhas e o seu entranhamento nos autos processuais, o transporte de autos entre diferentes unidades, o atendimento do público para a exibição dos autos no cartório para consulta. Com a evolução do uso do processo eletrônico e a sua inserção gradual na mentalidade e cultura jurídicas, tradicionalmente vinculada ao uso do papel, pode-se vislumbrar mudanças mais profundas e radicais nas técnicas processuais, mudanças estas permitidas pelo desenvolvimento do processo no mundo virtual, extrapolando o mundo físico e as limitações dele decorrentes. Em um exercício puramente imaginativo, pode-se citar, dentre essas limitações, às de caráter territorial, vez que o processo eletrônico pode ser disponibilizado a qualquer pessoa independentemente de sua localização geográfica, bem assim quanto à forma de organização e apresentação das participações das partes, superando-se a vinculação da produção de atos processuais em documentos unilaterais, vez que no mundo digital, por exemplo, é possível que todas as partes produzam suas manifestações de forma sucessiva em um mesmo documento por elas compartilhado, no qual restem consignadas a autoria e a data de cada uma das intervenções.

${ }^{15}$ Sem que, em contrapartida, acarrete um necessário aumento de sua retribuição.
} 
constitucionais da vitaliciedade, inamovibilidade e irredutibilidade de vencimentos, recaem sobre o juiz consequências por não desenvolver o seu trabalho de forma tempestiva ${ }^{16}$.

O risco que decorre dessa realidade diz respeito à perda da qualidade do serviço jurisdicional, acarretando prejuízo às partes. Formalismos exacerbados e o sacrifício de faculdades e poderes processuais das partes previstos em lei não representam medidas de acesso à ordem jurídica justa, mesmo porque nem mesmo assim a prestação jurisdicional se torna célere. Considerando-se os escopos processuais, privilegia-se somente a pacificação, sem justiça e de forma tardia.

\subsection{EFETIVIDADE PROCESSUAL}

O direito de ação, na sua concepção constitucional, refere-se ao acesso ao Poder Judiciário, ou seja, "ao instrumento estatal de resolução de conflitos" ${ }^{17}$, e à justiça.

Entendendo restarem hoje superadas as longas discussões a respeito da natureza do direito de ação, reservando-se-lhes mero valor histórico, José Roberto dos Santos Bedaque propugna um exame do direito de ação sob a perspectiva da efetividade do processo. A esse respeito, entende o direito de ação como "direito de obter concretamente os meios necessários à satisfação de um interesse protegido pelo legislador material" ou "garantia de

\footnotetext{
16 "Clama-se, e de há muito, por uma Justiça mais célere. Abandone-se, por ora, o dilema entre celeridade e qualidade. Parece nítida a opção pela rapidez, quando o defeito mais evidente do Judiciário é a sua lentidão. A refletir-se no texto constitucional vigente, quando prioriza a presteza como critério mais relevante para aferição do merecimento do juiz. A prioridade é tornar o serviço judicial mais rápido. Se possível, sem prejuízo da qualidade bem acima da razoável." (NALINI, 1998, p. 167). Lembre-se que, por efeito da Emenda Constitucional 45/2004, incluiu-se na alínea "c" do inciso II do artigo 93 da Constituição a produtividade ao lado da certeza como critérios para a promoção dos juízes por merecimento. A mesma emenda incluiu a alínea "e", impedindo a promoção de juízes que retiverem autos fora do prazo legal. No âmbito infra-constitucional, a CLT, por exemplo, no seu artigo 658, alínea "d", prevê a perda de vencimentos pelo não atendimento dos prazos legais. Também com a Emenda Constitucional 45/2004, criou-se o Conselho Nacional de Justiça, órgão de controle do Poder Judiciário, que, dentre outras diretrizes, impõem metas aos tribunais, inclusive no que toca ao julgamento de processos com base na data de sua propositura.

17 BEDAQUE, 2009, p. 65. O direito constitucional da ação não se restringe pela disciplina infraconstitucional das normas processuais, não se confundindo com o poder de propor demandas. As condições da ação, segundo José Roberto dos Santos Bedaque dizem respeito ao provimento concreto pleiteado ao juiz, e não à própria garantia constitucional de ação. As condições da ação, nesse sentido, seriam técnica destinada a possibilitar o exame sumário e inicial da relação de direito material trazida ao processo, de modo a extingui-lo se desde logo ficar constatado ser a tutela jurisdicional pleiteada inviável, atendendose, assim, ao princípio da celeridade e da economia processual. Se tal decisão opera efeitos materiais ou somente formais é decisão do legislador. (BEDAQUE, 2009, pp. 79/81)
} 
acesso efetivo ao meio necessário à satisfação de um interesse" ${ }^{18}$. Configura direito vinculado a direito substancial afirmado, mas não necessariamente existente, eis que se busca a tutela jurisdicional sempre alegando a existência de um direito que, pode ou não, de fato existir. Assim, apesar da garantia da ação não assegurar o direito material que se alega possuir, não se restringe a franquear o livre acesso ao Poder Judiciário. Mais do que isso, importa garantia de meio e resultado - não necessariamente aquele buscado pelo demandante -, sendo tal meio aquele previsto na norma constitucional para atingir a finalidade, conforme as garantias constitucionais do processo - o devido processo constitucional.

A garantia de acesso não pode ser meramente formal, fazendo-se necessário criar condições reais para que a ação seja concretamente utilizada, não apenas no que toca à possibilidade de ingresso no Judiciário, mas também a respeito do desenvolvimento do processo em conformidade com suas garantias constitucionais e dele resultando a tutela efetiva do direito material subjacente. Seu objeto não diz respeito à obtenção de um resultado favorável, mas sim aos meios adequados para que possa ocorrer, se o caso. ${ }^{19}$ Daí o acesso à Justiça assumir o contorno de "acesso à ordem jurídica justa" 20.

A esse respeito, há de se eliminar os óbices econômicos, culturais, sociais e técnicos à efetividade processual. Nesse tocante, por exemplo, considerando que os custos do processo podem ser um entrave relevante, é preciso se prever mecanismos para eliminá-lo nos casos concretos em que efetivamente seja um óbice. ${ }^{21}$ Atento a esse problema, prevê o legislador a possibilidade da assistência judiciária gratuita, inclusive por meio da isenção de custas processuais, disponibilização dos serviços jurídicos prestados pela Defensoria Pública, ou mesmo a concessão à própria parte do jus postlandi em certas hipóteses, como para demandar perante a Justiça do Trabalho e os Juizados Especiais, dispensando-se a exigência de advogado.

A observância da efetividade processual não atende apenas às partes em conflito, mas ao interesse público, na perspectiva publicista do processo, eis que importa a atuação das

\footnotetext{
${ }^{18}$ BEDAQUE, 2009, pp. 70 e 73.

${ }^{19}$ BEDAQUE, 2009, p. 77.

${ }^{20}$ BEDAQUE, 2009, p. 78.

${ }^{21}$ BEDAQUE, 2009, p. 76.
} 
normas de direito material violadas, bem assim a promoção da pacificação social com justiça $^{22}$.

Constatada a relação de interação entre os planos material e processual, deve-se equipar o direito processual de mecanismos voltados a proporcionar tutela adequada às diversas situações de direito material que despontam na prática. Os instrumentos postos à disposição do sujeito titular da relação de direito material devem ser estruturados de forma a ensejar, mais do que a tutela formal, a tutela efetiva do seu direito da maneira mais próxima possível àquilo que resultaria do cumprimento espontâneo pelo réu do comportamento previsto na norma de direito material. ${ }^{23}$ Nesse tocante, apontam Mauro Cappelletti e Bryant Garth:

Ademais, esse enfoque reconhece a necessidade de correlacionar e adaptar o processo civil ao tipo de litígio. Existem muitas características que podem distinguir um litígio de outro. Conforme o caso, diferentes barreiras ao acesso podem ser mais evidentes, e diferentes soluções, eficientes ${ }^{24}$.

O desafio da ciência processual moderna está na eficiência da Justiça por meio do desenvolvimento de mecanismos que resultem na efetividade da tutela processual. ${ }^{25} \mathrm{O}$ foco reside nos resultados derivados do processo, que devem corresponder àqueles que dele se espera advir. Daí porque os mecanismos processuais devem ser adequados às diferentes relações de direito material subjacentes que constituirão o seu objeto.

Uma das maneiras de se apurar a efetividade do processo se perfaz pela análise de duas ordens de parâmetros: os de produção e os de qualidade. Os primeiros se prendem a questões de utilidade e eficiência, indicando aqueles mecanismos capazes de levar ao resultado almejado com menores custos, no exercício de uma ponderação interna. Os segundos, implicam uma análise dos benefícios proporcionados por uma decisão resultante de um dado processo decisório, dando azo a uma comparação dos mecanismos decisórios

\footnotetext{
${ }^{22}$ BEDAQUE, 2009, p. 78.

${ }^{23}$ BEDAQUE, 2009, p. 13.

${ }^{24}$ GARTH; CAPPELLETTI, 1988, p. 71.

${ }^{25}$ BEDAQUE, 2009, p. 15.
} 
disponíveis de modo a se apurar qual produz o melhor resultado tendo em vista as finalidades buscadas, perfazendo-se um exercício de ponderações externas. ${ }^{26}$

As considerações a respeito da efetividade do processo devem ser amplas de forma a abarcar elementos externos ao próprio sistema processual, não ficando restritas aos elementos internos. O exame da adequação dos mecanismos decisórios levam em conta tanto aqueles objetivos imediatos relacionados ao provimento do bem da vida à parte em conformidade com o direito material, como também seus objetivos mediatos, referentes aos valores presentes no direito objetivo. A sentença proferida de forma célere e com baixo custo pode não ser adequada na medida em que sacrifique o contraditório de forma indevida, por exemplo ${ }^{27}$.

Nessa toada, considerando que a realidade do sobrecarregamento do Poder Judiciário representa uma forma de inefetividade, devem ser buscados mecanismos para tornar a tutela jurisdicional capaz de dar tratamento adequado ao conjunto de demandas que lhe são trazidas. Não somente a celeridade, mas também a qualidade do provimento devem se apresentar.

\subsection{EFETIVIDADE E TEMPO}

A questão do tempo representa aspecto relevante o que toca à efetividade processual. $\mathrm{O}$ processo deve ser capaz de assegurar para a parte a realização plena do seu direito na máxima extensão possível. Entre a violação de um direito e a obtenção da tutela jurisdicional do mesmo transcorre um período. Esse tempo associado à duração do processo representa um fator de diminuição do aproveitamento do direito ${ }^{28}$.

\footnotetext{
${ }^{26}$ SALLES, 2003, p. 50/51.

27 SALLES, 2003, pp. 51/52.

28 José Roberto dos Santos Bedaque aponta que prevalece o caráter sancionatório no sistema de tutela processual, atuando após a violação do direito, no mais das vezes de forma ressarcitória. Por mais que possa funcionar no que toca a direitos patrimoniais, há muitos outros que não possuem conteúdo exclusivamente econômico, como, por exemplo, os direitos fundamentais, os interesses metaindividuais, os direitos de família. Nesses casos, a tutela ressarcitória não se mostra adequada, exigindo-se do processo que opera efeitos para impedir a lesão ao direito, como, por exemplo, por meio das tutelas de urgência. (BEDAQUE, 2009, pp. 18/19).
} 
Muito embora sejam previstas no ordenamento medidas para mitigar os efeitos deletérios do tempo ${ }^{29}$, podem tais efeitos acabar sendo relevantes para as partes, de forma a que a tutela jurisdicional resultante do processo não venha a proporcionar ao tutelado a mesma utilidade que lhe traria a satisfação voluntária ${ }^{30}$. A substituição do cumprimento de uma obrigação de fazer inadimplida pelo pagamento de indenização, por exemplo, não retrata o pleno cumprimento do direito material original. O pagamento tardio de uma dívida, por mais que acrescido de juros de mora, pode ter significado para o credor um longo período de aflições e dificuldades que não se compensam com uma quantia em dinheiro. Ademais, juros de mora aplicados por anos podem remontar a valores expressivos, mas isso não significa que o devedor terá condições de efetuar o correspondente pagamento, considerando, inclusive que o fato de estar em mora pode ser indício de não possuir recursos em abundância.

José Roberto dos Santos Bedaque, atento aos efeitos decorrentes do trâmite processual para a efetividade do direito, seja em razão da própria demora, seja pelo risco de acontecimentos nesse meio tempo agravarem ainda mais a situação do titular do direito e inviabilizarem a tutela final, reconhece que "O simples fato de o direito permanecer insatisfeito durante todo o tempo necessário ao desenvolvimento do processo cognitivo já configura dano ao seu titular". Esse é conhecido como dano marginal ${ }^{31}$.

Encarado o processo sob a perspectiva do procedimento, nota-se que para que os sujeitos do processo possam praticar atos processuais, fazendo valer seus poderes, faculdades, ônus, deveres e sujeições processuais, sob a égide dos princípios da demanda, do contraditório, da ampla defesa e do devido processo legal, faz-se necessário tempo. Os atos praticados pelos serventuários e demais auxiliares da justiça, essenciais para o andamento do procedimento, também demandam tempo. No processo de conhecimento, as atividades

\footnotetext{
29 "Procura o legislador abrandar o problema, criando mecanismos, no plano substancial e processual, para desestimular atitudes contrárias ao direito, tornar mais rápido o provimento judicial e possibilitar a perfeita correspondência entre o resultado do processo e a vantagem conferida pelo legislador material.

Nessa linha, existem normas destinadas a agravar a obrigação caso haja descumprimento, impondo ao devedor inadimplente sanção por esse comportamento. São exemplos os juros moratórios, as multas e as astreintes. Entram ainda nessa categoria o penhor, a hipoteca e outros institutos destinados a reforçar o cumprimento espontâneo da obrigação" (BEDAQUE, 2009, p. 20).

${ }^{30}$ BEDAQUE, 2009, p. 20.

${ }^{31}$ BEDAQUE, 2009, p. 21.
} 
cognitivas do julgador importam a realização de diversos atos, que impedem a concessão imediata da tutela ${ }^{32}$.

Nada obstante o tempo necessário para que o processo possa se desenvolver e culminar na tutela jurisdicional definitiva de um direito, com a preservação das garantias de participação das partes, fenômeno que com frequência passa a ser observado é o trâmite processual se prolongar por período em muito superior ao imprescindível, caracterizando o que veio a se denominar de duração patológica ${ }^{33}$.

Por meio da Emenda Constitucional 45 de 2004, acresceu-se ao rol dos direitos e garantias fundamentais constante do artigo $5^{\circ}$ da Constituição de 1988, o direito de todos à "razoável duração do processo e os meios que garantam a celeridade de sua tramitação".

O principal destinatário do dever decorrente do reconhecimento do direito à duração razoável do processo é o próprio Estado, em todos as suas funções: legislativa, executiva e judicial. No plano legislativo, especialmente no que toca ao desenvolvimento de mecanismos processuais mais efetivos, considerando as especificidades de diversas situações de direito material e o seu tratamento processual mais ajustado e eficiente. No que toca à Administração Pública, a diminuição do número de feitos e a abstenção do uso de recursos e incidentes infundados para prolongá-los, calcados em interpretação afastada pelos tribunais superiores. Para o Poder Judiciário, significa melhorias estruturais e organizacionais, controle administrativo das atividades de servidores e juízes, qualificação do pessoal e emprego adequado das técnicas processuais previstas no ordenamento.

No que toca à técnica processual, diversos são os exemplos de medidas desenhadas para certas situações de direito material que importam em redução do tempo do processo, ou pelo menos antecipação do provimento jurisdicional. A denunciação da lide permite ao denunciante envolver o denunciado no processo deduzindo sua pretensão de regresso incidentalmente. A execução provisória implica atos executórios antes da sentença de mérito assumir caráter de imutabilidade. A dispensa da ação de conhecimento para a execução de títulos executivos extrajudiciais, diante da certeza encartada no título, relevam-se as atividades de cognição. Técnicas de sumarização da atividade cognitiva

\footnotetext{
${ }^{32}$ BEDAQUE, 2009, p. 17.

${ }^{33}$ BEDAQUE, 2009, p. 21.
} 
também são adotadas nesse sentido, seja, por exemplo, mediante a concentração de atos em procedimentos sumários, ou pela previsão de tutelas de urgência para os casos em que, baseando-se em juízo de verossimilhança, ao juiz é dado conceder medida cautelar ou antecipatória a fim de assegurar o objeto do processo ou o próprio direito pleiteado tendo em vista os males maiores que resultariam de se aguardar o término do processo ${ }^{34}$.

\subsection{EXAME DO PROBLEMA SOB A PERSPECTIVA INSTRUMENTALISTA}

No sentido de buscar o melhor equacionamento para a resolução dos processos repetitivos, deve-se identificar quais são as suas características e, com base, nelas, como se pode introduzir aperfeiçoamentos no sistema de forma a permitir o atendimento mais satisfatório dos escopos da jurisdição, dando bases para o Poder Judiciário prestar o serviço jurisdicional de forma tempestiva e com justiça, não só com relação às causas repetitivas, mas também aos demais processos que sofrem efeitos deletérios em razão do sobrecarregamento do sistema e dos esforços pontuais e, muitas vezes, irrazoáveis por parte do Poder Judiciário no sentido de dar-lhes um fim, seja qual for ${ }^{35}$.

Não é de se esperar que as soluções assim cogitadas não apresentem efeitos negativos, no que toca ao atendimento de princípios constitucionais, caracterizando conflito entre princípios e valores do sistema. Nesse sentido, há de se socorrer do princípio da proporcionalidade para daí derivar a solução que proporcione o mais amplo atendimento de todos os princípios envolvidos ${ }^{36}$.

\footnotetext{
${ }^{34}$ BEDAQUE, 2009, pp. 25/27.

35 Ao se dar tratamento coletivizado para causas repetitivas, desobstrui-se o Judiciário para concentrar seus esforços no julgamento de outras demandas em curso (ARENHART, 2013, p. 29).

36 "Segundo esse preceito, a ponderação entre os vários princípios constitucionais em choque - a fim de extrair-se a solução melhor ao caso concreto - deve ser informada por três sub-critérios: impõe-se a avaliação do ato (ou seja, do ato legislativo, do ato administrativo ou do ato jurisdicional) à luz de sua adequação, de sua necessidade e de sua proporcionalidade. Grosso modo, e recuperando as ponderações feitas no capítulo inicial, de acordo com o primeiro ponto (adequação, ou geeignet), exige-se que a providência a ser adotada seja apropriada para a obtenção da finalidade constitucional (ou, ao menos, para a sua facilitação). Já a verificação da necessidade da medida (erfordelich) impõe a verificação sobre a existência ou não de outros meios mais idôneos para a obtenção do escopo almejado, sem sacrifício (ou com menor sacrifício) dos outros valores constitucionalmente prezados. Finalmente, em razão da proporcionalidade sem sentido estrito (angemessen) deve-se examinar se os eventuais efeitos colaterais negativos (para os demais direitos fundamentais), resultantes da providência a ser tomada, não superam as vantagens decorrentes da adoção da prática - ou seja, exige-se o sopesamento dos prós e dos contras que podem decorres da medida para outros valores constitucionais." (ARENHART, 2013, pp. 34/35).
} 
Não é, entretanto, a implementação de mudanças na técnica processual a única ou melhor via em que se deve operar para atingir os escopos pretendidos. Esforços também devem ser desenvolvidos no que toca à questões estruturais e do manejo dos recursos postos à disposição do Poder Judiciário, bem assim a respeito da cultura de resolução de conflitos judicializada e individualista prevalecente nos tempos atuais ${ }^{37}$.

Aponta-se como uma das necessidades, a destinação orçamentária de recursos razoáveis para o Poder Judiciário, de forma a que possa aplicá-los na prestação do serviço jurisdicional. Também questões estruturais e organizacionais exercem papel relevante nesse tocante. $\mathrm{O}$ aumento do número de juízes e a redistribuição da competência para balancear o número de processos entre os diferentes órgãos jurisdicionais representam medidas sugeridas por José Roberto dos Santos Bedaque nesse tocante ${ }^{38}$.

Apesar de essencial, não basta, contudo, o aprimoramento dos recursos empregados de forma eficiente no Poder Judiciário, eis que a tendência aponta o aumento do número de causas, sobretudo ao se considerar a amplitude de acesso proporcionada por iniciativas que buscam desafogar a Justiça. ${ }^{39}$ Cumpre, assim, investigar os demais aspectos do problema.

A respeito das questões culturais, dentre outros, dois pontos devem ser considerados. Em primeiro lugar, o desenvolvimento da cultura das soluções coletivizadas para os conflitos. De nada adianta o desenho de instrumentos processuais adaptados a dar uma resposta adequada à situação que se apresenta se as partes deles não se valem, seja por despreparo, desconhecimento ou receio de mudanças. Nessa categoria incluem-se partes, advogados, juízes e demais operadores do direito.

\footnotetext{
37 "O bom funcionamento da técnica processual, por mais perfeita que possa parecer aos olhos do processualista, depende fundamentalmente das pessoas que a operam e da estrutura criada para sua aplicação. Se as reformas processuais não forem acompanhadas de alterações estruturais profundas na organização do Poder Judiciário, com preocupações voltadas para a formação e aperfeiçoamento do julgador, corre-se o risco de novas frustrações, pois os instrumentos não encontrarão condições favoráveis para aplicação." (BEDAQUE, 2009, p. 17).

${ }^{38}$ BEDAQUE, 2009, p. 16.

39 "E a solução não consiste exclusivamente no aumento no número de magistrados, pois quanto mais fácil for o acesso à Justiça, quanto mais ampla a universalidade da jurisdição, maior será o número de processos, formando uma verdadeira bola de neve." (GRINOVER, Ada Pellegrini. Os Fundamentos da Justiça Conciliativa. In GRINOVER, Ada Pellegrini; LAGRASTA NETO, Caetano; WATANABE, Kazuo (coord.). Mediação e Gerenciamento do Processo: revolução na prestação jurisdicional. São Paulo: Atlas, 2013, p. 2).
} 
A esse respeito, chama atenção a falta de incentivos para o florescimento de uma cultura associativa no país, inclusive em função do efeito free rid, na medida em que a atuação da associativa produzirão externalidades positivas para os demais membros da coletividade em questão. A tendência dos sujeitos é a de maximizar os seus ganhos e minimizar os seus custos. Considerando a decisão de ingressar ou não em entidade associativa tendo por objeto a defesa de interesse que também lhe pertence, em razão do efeito free riding tenderá o sujeito a pemanecer inerte ${ }^{40}$. Isso porque independentemente de sua participação na associação, o trabalho por ela desenvolvido, com os recursos dos seus associados, necessariamente o beneficiará por fazer parte da coletividade em questão. Ademais, como o resultado de um processo coletivo não prejudica eventual demanda individual, não lhe afligirá qualquer receito de que o resultado produzido poderá lhe ser desfavorável. Desse modo, para ele não será vantajoso se associar e arcar com as obrigações e ônus decorrentes dessa condição. Por consequência, os sujeitos que de outro modo estivessem dispostos a fazer parte da associação ficarão desestimulados na medida em que os esforços, recursos e riscos serão somente por eles empregados ou suportados, mas os eventuais efeitos benéficos decorrentes do trabalho desenvolvido também necessariamente beneficiarão os demais, que não contribuíram para o resultado buscado. Soma-se a esse fato a possibilidade de questões de índole coletiva virem a ser objeto de atuação do Ministério Público, o que, apesar de configurar uma resposta para o deficiente associativismo, não contribui para o seu florescimento. Ao invés de se promover a demanda, prefere-se provocar a atuação do Parquet.

Esse fenômeno é observado nos tempos atuais, na esfera extrajudicial, no que diz respeito a associações de moradores de bairros e loteamentos que se formam para proporcionar melhoramentos e serviços para a área, tais como a contratação de segurança privada, a instalação e manutenção de portarias, a conservação de áreas públicas abandonadas pelo Poder Público. Apesar de beneficiar a todos, somente aqueles que tenham se associado arcam com os custos dos serviços por intermédio das contribuições pagas à associação. Como reação ao problema, tentativas há por parte das associações de cobrarem valores dos moradores não-associados com base no princípio da vedação ao enriquecimento sem causa, sob a alegação de que referidos sujeitos estariam enriquecendo por se beneficiarem dos serviços sem por eles pagarem qualquer contraprestação. A defesa contra aludida cobrança,

\footnotetext{
${ }^{40}$ SALLES, 1999, p. 129.
} 
por outro lado, tem base constitucional, fundando-se principalmente no princípio da liberdade de associação, uma vez que se exigir o pagamento seria impor ao não-associado condição análoga a de associado, fazendo-o inclusive compartilhar os objetivos buscados pela associação, que podem não estar de acordo com as suas prioridades.

Curiosamente, a resolução dessa questão é incidental ao objeto de inúmeros processos judiciais em trâmite no país, travados com relação a situações jurídicas materiais diversas estabelecidas entre um vasto número de moradores e outro vasto número de associações, cada qual com peculiaridades que as distingue (e.g., estatutos, objetivos, critérios para composição das contribuições). Pende, a esse respeito, julgamento de recurso extraordinário no Supremo Tribunal Federal, ao qual foi reconhecida repercussão geral ${ }^{41}$.

$\mathrm{O}$ outro aspecto cultural diz respeito à cultura da sentença ${ }^{42}$ à adoção de outros mecanismos de solução de controvérsias que não o judicial ${ }^{43}$. Nota Ada Pellegrini Grinover, aliás, que "o renascer das vias conciliatórias é devido, em grande parte, à crise da Justiça" ${ }^{44}$. Reconhece-se que são mais limitadas as possibilidades de acordos no que toca a direitos coletivos, sobretudo em razão de sua indisponibilidade, que leva à impossibilidade de transação quanto ao seu objeto, nada obstante a previsão da figura do compromisso de ajustamento de conduta. Soma-se a isso a circunstância de que o resultado eventualmente obtido, da mesma forma que nas ações coletivas, não poderá ter o condão de prejudicar as pretensões individuais correspondentes, de forma a não evitar o desenvolvimento dos processos repetitivos.

\footnotetext{
${ }^{41}$ Repercussão Geral no Agravo de Instrumento 745.831 São Paulo, Relator Min. Dias Toffoli. A questão encontra-se no bojo do Recurso Extraordinário 695911, sob a mesma relatoria.

${ }^{42}$ Segundo Kazuo Watanabe: "a mentalidade forjada nas academias e fortalecida na práxis forense é aquela já mencionada, de solução adjudicada autoritativamente pelo juiz, por meio de sentença, mentalidade essa agravada pela sobrecarga excessiva de serviços que têm os magistrados (os juízes cíveis da Capital do Estado de São Paulo recebem, anualmente, cerca de 5.000 novos processos). Disso tudo nasceu a chamada cultura da sentença, que se consolida assustadoramente. Os juízes preferem proferir sentença ao invés de tentar conciliar as partes para a obtenção da solução amigável dos conflitos. Sentenciar, em muitos casos, é mais fácil e mais cômodo do que pacificar os litigantes e obter, por via de consequência, a solução dos conflitos." (WATANABE, Kazuo. A Mentalidade e os Meios Alternativos de Solução de Conflitos no Brasil. In GRINOVER, Ada Pellegrini; LAGRASTA NETO, Caetano; WATANABE, Kazuo (coord.). Mediação e Gerenciamento do Processo: revolução na prestação jurisdicional. São Paulo: Atlas, 2013, p. 7).

${ }^{43}$ Aponta Ada Pellegrini Grinover que as técnicas da conciliação e mediação, estão em conformidade com os escopos da jurisdição, tendo fundamentos (i) funcionais, servindo como método de desobstrução dos tribunais e de aprimoramento do desempenho e funcionalidade da justiça; (ii) sociais, proporcionando a pacificação social, inclusive do conflito sociológico; e (iii) político, por ensejar participação popular. (GRINOVER, 2013, pp.2-5).

${ }^{44}$ GRINOVER, 2013, p. 2.
} 
Entretanto, nada impede que se desenvolvam mecanismos coletivos alternativos de solução de conflitos individuais marcados por um elemento comum. A prática mostra exemplos de casos desse jaez, vinculados a eventos de massa, especialmente de caráter catastrófico. Nesse tocante, mencionam-se dois casos ocorridos nos Estados Unidos ilustrativos desses mecanismos.

Em razão dos atentados terroristas ocorridos naquele país em 11 de setembro de 2011, perpetrados com o uso de aeronaves comerciais, vitimando milhares de pessoas e levando à destruição de edifícios privados e públicos, além de inúmeros outros bens, o Congresso dos Estados Unidos criou, por meio de ato legislativo ${ }^{45}$, um fundo de compensação para as vítimas do acidente, prevendo o pagamento de indenizações, independentemente de comprovação de culpa, para aquelas que fossem elegíveis e que aderissem ao mecanismo de compensação administrativo, abrindo mão de qualquer outro direito indenizatório contra eventuais responsáveis pelos danos que fossem nacionais daquele país. Nos três meses de duração do fundo, 97\% das famílias elegíveis a ele aderiram voluntariamente e 2.300 indivíduos que sofreram lesões optaram por receber o pagamento administrativamente. Mais de US\$ 7 bilhões foram pagos a título de indenização. Um dos fatores que se afirma ter contribuído para o sucesso do fundo foi a previsão da possibilidade de uma audiência com os gestores, a qual acabou por servir como veículo para as vítimas expressarem sua dor pelo ocorrido, demonstrando como o conflito não se encerra nas questões pecuniárias $^{46}$.

O segundo caso refere-se ao derramamento de petróleo na Bahia do Golfo do México decorrente de acidente com vítimas nas operações da British Petroleum (BP), causando um impacto ambiental de elevada proporção, atingindo pessoas e indústrias em diversos países. A empresa voluntariamente se comprometeu perante o governo norte-americano a estabelecer um fundo indenizatório disponibilizando montante da ordem de US\$ 20 bilhões. Desenvolveu-se, assim, um mecanismo de resolução de disputas, com a criação do Gulf Coast Claims Facility, e a determinação de critérios de determinação de elegibilidade, dos parâmetros para os cálculos das indenizações e das quitações que seriam exigidas em retorno. Por volta de US\$ 6 bilhões foram pagos para mais de quinhentas mil pessoas e

\footnotetext{
4549 U.S.C. $\S \S 40101,44302-44306$ (2006).

${ }^{46}$ FELSBERG, Keneth. Democratization of Mass Litigation: Empowering the Beneficiaries. In Columbia Journal do Law and Social Problems, vol. 45, 2012, p. 491.
} 
empresas, a grande maioria das quais mediante quitação de todo e qualquer valor devido, abrindo mão da via judicial. Nota-se, entretanto, que, apesar de ser considerado um sucesso em razão dos resultados produzidos, foi alvo de insatisfações e acusações de má-fé, sobretudo em face de muitas demandas terem restado negadas sem justificativas pormenorizadas, ressentindo-se o mecanismo da falta das audiências que marcaram o seu antecessor. $^{47}$

No Brasil, práticas imbuídas do mesmo espírito, por mais que não sejam comuns, já foram adotadas. O Estado, por exemplo, reconhecendo a existência de expurgos inflacionários ocorridos entre dezembro de 1988 e fevereiro de 1988 e abril de 1990, com relação a saldo de FGTS, por meio da Lei Complementar 110/2001, previu, nos termos do artigo $4^{\circ}$, a possibilidade do titular da conta vinculada receber os valores pertinentes a tais expurgos mediante assinatura de termo de adesão padrão instituído de acordo com o artigo $6^{\circ}$ de aludida lei, por meio do qual o beneficiado manifesta aceitar as condições impostas, abrindo mão de parte de seus direitos (parcelamento do pagamento e deságio) ${ }^{48}$.

Outro mecanismo pontual desenvolvido no país foi a Câmara de Indenização 3054, referente ao acidente com o vôo TAM 3054, ocorrido em 2007, por meio da qual a companhia aérea, a seguradora envolvida e diversos órgãos do Sistema Nacional de Defesa do Consumidor estabeleceram um mecanismo para a mediação dos conflitos envolvendo as famílias das vítimas, partindo de proposta indenizatória formulada pelas empresas para os interessados aderentes, com base em certos parâmetros pré-fixados. $\mathrm{O}$ saldo foi de acordo em $92 \%$ dos casos iniciados, representando indenização para $23 \%$ das famílias das vítimas ${ }^{49}$.

Nota-se, nesses casos, que aludidos mecanismos concretizam os escopos da jurisdição, inclusive resolvendo a lide sociológica que subjaz o conflito jurídico que normalmente é

\footnotetext{
${ }^{47}$ FELSBERG, 2012, pp. 494-496.

${ }^{48}$ Curioso notar que, nada obstante o número massivo de sujeitos que celebram o acordo, posteriormente surgiu uma onda de processos repetitivos em que se questionava a validade do ajuste, tendo resultado na primeira Súmula Vinculante editada pelo Supremo Tribunal Federal, com o seguinte teor: "Ofende a garantia constitucional do ato jurídico perfeito a decisão que, sem ponderar as circunstâncias do caso concreto, desconsidera a validez e a eficácia de acordo constante de termo de adesão instituído pela lei complementar 110/2001".

49 Balanço de Atividades. Câmara de Indenização Vôo TAM 3054. Disponível em http://www.defensoria.sp.gov.br/dpesp/Repositorio/0/Documentos/CCSAI/relatorio_camara02.pdf. Acessado em 20 de dezembro de 2013.
} 
levado ao Judiciário e proporcionando uma solução consensual que, de certa forma e em razão dessa sua natureza, deixa as partes conflitantes satisfeitas. ${ }^{50}$ Mesmo que as soluções sejam individualizadas, não deixam de caracterizar um mecanismo coletivo de resolução de litígios, partindo de definições gerais a serem aplicados aos casos que sejam apresentados, seja no tocante ao reconhecimento de responsabilidade por parte do infrator, ou nas definições a respeito de elegibilidade, instrumentos de prova, cálculo e pagamento.

Além das questões administrativas e culturais apontadas, também há de se examinar a questão sob a perspectiva do tratamento processual adequado para os casos repetitivos. A esse respeito, nota-se que a característica que compartilham e que permite serem considerados repetitivos, diz respeito à repetição de uma questão, especialmente de natureza jurídica ${ }^{51}$.

Em vista dessa característica, inovações foram introduzidas no sistema no sentido de tentar realizar o aproveitamento da resolução da questão comum realizada em um processo para, de alguma forma, causar efeito nas demais que se apresentassem em outras causas repetitivas, sem prejuízo, é claro, de outras questões específicas trazidas em tais processos. Essas técnicas se baseiam na valorização da jurisprudência e na agregação de casos para julgamento conjunto. Como apresentam fonte de inesgotável de controvérsias, que escapam ao propósito do presente estudo, não serão aludidas técnicas aqui exploradas, limitando-se a mencioná-las e apresentar o seu regime legal, com apontamentos a respeito da mudança do papel desempenhado pela jurisprudência.

Tradicionalmente, no sistema de Civil Law, a jurisprudência não é vista como fonte de direito, mas mero repertório argumentativo indicativo da interpretação dos preceitos legais pelos tribunais para a fixação das normas concretas nas situações que lhe são submetidas.

\footnotetext{
50 "Revela, assim, o fundamento social das vias conciliatórias, consistente na sua função de pacificação social. Esta, via de regra, não é alcançada pela sentença, que se limita a ditar autoritativamente a regra para o caso concreto, e que, na maioria dos casos, não é aceita de bom grado pelo vencido, o qual contra ela costuma insurgir-se com todos os meios na execução; e que, de qualquer modo, se limita a solucionar a parcela da lide levada a juízo, sem possibilidade de pacificar a lide sociológica, em geral mais ampla, da qual aquela emergiu, como simples ponta do iceberg. Por isso mesmo, foi salientado que a justiça tradicional se volta para o passado, enquanto a justiça informal se dirige para o futuro. A primeira julga e sentencia; a segunda compõe, concilia, previne situações de tensões e rupturas, exatamente onde a coexistência é um relevante elemento valorativo" (GRINOVER, 2013, pp 3-4).

${ }^{51}$ Não se nega que também possam compartilhar questões fáticas, como, por exemplo, a potencialidade de determinado princípio ativo causar danos à saúde, que pode ser incidental a inúmeros processos movidos contra diversas empresas fornecedoras de medicamentos produzidos com o uso de tal componente.
} 
Nesse condão, é empregada pelas partes com caráter meramente persuasivo, e integrada pelos juízes na fundamentação de suas decisões, corroborando o seu entendimento extraído do próprio ordenamento jurídico.

Vislumbra-se nas últimas décadas, no entanto, no direito processual brasileiro uma tendência de valorização da jurisprudência, com a intenção é de dar maior aproveitamento à apreciação das questões jurídicas pelos tribunais, especialmente os tribunais superiores, de modo que em se firmando certos entendimentos nesses foros, sejam eles seguidos nas demais instâncias.

Verifica-se, assim, a existência de diversas regras que atribuem força a julgamentos passados para a resolução de casos presentes. Em tal rol encontram-se a súmula vinculante, a súmula impeditiva de recursos, casos de julgamento monocrático de recursos pelo relator, exceções ao reexame necessário e o julgamento liminar de improcedência da ação. ${ }^{52}$

A existência de entendimentos jurisprudenciais diversos em alguns casos também pode ensejar o cabimento de meios de impugnação de decisões judiciais, tais como recurso especial e recurso extraordinário por divergência jurisprudencial, embargos de divergência, reclamação ao Supremo Tribunal Federal e ao Superior Tribunal de Justiça. Nos tribunais, o próprio magistrado pode, ao verificar a divergência de entendimentos jurisprudenciais sobre a matéria recorrida, suscitar incidente de uniformização de jurisprudência. No controle difuso de constitucionalidade, é desnecessária a submissão da alegação de inconstitucionalidade pelo relator ao plenário ou órgão especial do tribunal caso estes colegiados ou o Supremo Tribunal Federal já tenham se manifestado sobre o assunto.

\footnotetext{
${ }^{52}$ Diversas técnicas já foram criadas no Brasil para lidar com os processos repetitivos. Ada Pellegrini Grinover destaca a súmula vinculante do Supremo Tribunal Federal; a aferição, por amostragem, da repercussão geral de questões constitucionais, aplicando-se, ainda, a decisão da Corte aos demais processos; o julgamento de recursos especiais pelo Superior Tribunal de Justiça também por amostragem, com o fim de negar seguimento a recursos sobre a mesma tese de direito; súmulas de jurisprudência dominante, impeditivas de recurso e, por fim, o julgamento de mérito pelo juiz de primeiro grau antes mesmo da citação do réu, nos casos de existência de sentenças anteriores de total improcedência em casos idênticos (GRINOVER, 2009, pp. 27/35). Luiz Guilherme Marinoni lembra também da admissão pelo Supremo Tribunal Federal do instituto da reclamação para a tutela da autoridade dos precedentes do Superior Tribunal de Justiça (EDcl no RE 571.572), o que também configura importante mecanismo para solução de processos repetitivos. O mesmo autor também ressalta a importância dos poderes atribuídos ao relator, que pode proferir julgamento monocrático com base em súmula, jurisprudência dominante ou precedente de tribunal superior, nos termos do art. 557 do Código de Processo Civil (MARINONI, Luiz Guilherme. Precedentes Obrigatórios. 2. ed. rev. e atual. São Paulo: Editora Revista dos Tribunais,2011, pp. 495 e 511 ).
} 
Não bastante, em outras técnicas, preveem-se mecanismos de agregação de julgamentos, de modo que o entendimento firmado na resolução da questão repetitiva em um caso deva ser estendida para os outros em curso, os quais, enquanto pendente o julgamento do primeiro, ficarão suspensos.

Havendo multiplicidade de recursos especiais com fundamento em idêntica questão de direito ou multiplicidade de recursos extraordinários com fundamento em idêntica controvérsia, prevê-se a seleção de recursos representativos da controvérsia a serem julgados, conforme o caso, pelo Superior Tribunal de Justiça ou pelo Supremo Tribunal Federal, sobrestando-se os demais recursos nos tribunais de origem até que o recurso selecionado seja julgado pelo tribunal superior.

Especialmente no que diz respeito ao recurso extraordinário, aliás, inseriu-se na Constituição da República novo requisito de admissibilidade que se relaciona à potencialidade do resultado do julgamento extrapolar o caso em questão, vindo a atingir outras relações jurídicas. Essa é a repercussão geral, que nos termos do Código de Processo Civil caracteriza-se pela a existência de questões relevantes do ponto de vista econômico, político, social ou jurídico, que ultrapassem os interesses subjetivos da causa ${ }^{53}$.

Cabe frisar que, no Supremo Tribunal Federal, reconhecendo-se a inexistência de repercussão geral, todos os recursos sobrestados deverão ser inadmitidos (art. 543-B, $\S 2^{\circ}$ do Código de Processo Civil), e se julgado o mérito do recurso representativo, aos tribunais de origem é dada a oportunidade de mais uma vez analisarem os recursos que se encontrem sobrestados, declarando-os prejudicados, retratando-se ou mantendo a decisão recorrida, caso este em que o Supremo Tribunal Federal, depois de admitido o recurso, poderá cassar ou reformar liminarmente o acórdão proferido em contrariedade com a orientação definida (art. 543-B, $\S \S 3^{\circ}$ e $4^{\circ}$ do Código de Processo Civil).

No Superior Tribunal de Justiça, com o julgamento do recurso especial representativo, os recursos especiais sobrestados nos tribunais de origem não deverão ser admitidos caso o acórdão recorrido esteja em linha com a orientação fixada pelo Superior Tribunal de

\footnotetext{
53 art. 543-A do Código de Processo Civil e 102, III, §3º da Constituição da República.
} 
Justiça, e deverão ser objeto de nova análise pelo próprio tribunal de origem no caso de confrontarem tal orientação (art. 543-C, $\$ 7^{\circ}$ do Código de Processo Civil).

O Anteprojeto de Código de Processo Civil elaborado por uma comissão de juristas presidida pelo Ministro Luiz Fux, dentre as inovações propostas, trouxe o chamado incidente de resolução de demandas repetitivas. Em essência, trata-se de incidente instaurado diretamente no tribunal, fundado na existência "de controvérsia com potencial de gerar relevante multiplicação de processos fundados em idêntica questão de direito e de causar grave insegurança jurídica, decorrente do risco de coexistência de decisões conflitantes" (Art. 895 do anteprojeto e 930 do projeto aprovado no Senado Federal). Admitido, enseja a suspensão de todos os processos em que se discuta a mesma questão jurídica em primeira e segunda instâncias no território de competência do tribunal, podendo tal efeito ser expandido para todo o território nacional pelo Superior Tribunal de Justiça ou Supremo Tribunal Federal, conforme a competência recursal. Prevê-se que o julgamento do incidente seja precedido de ampla divulgação e publicidade, permitindo-se a participação das partes e interessados. A análise do tribunal recairá sobre questões de direito e fixará orientação aplicável a todos os processos que versem sobre idêntica questão e que tenham trâmite no território sobre o qual recaia a competência do órgão jurisdicional prolator da decisão do incidente, com a possibilidade de extensão para todo o país se o Superior Tribunal de Justiça ou o Supremo Tribunal Federal vier a julgar recurso especial ou extraordinário, conforme o caso, interposto com relação à decisão do incidente.

Nesse contexto, são diversas as vozes da doutrina que enxergam uma aproximação entre as famílias da Common Law e da Civil Law, nada obstante se mantenham diferenças marcantes entre os sistemas ${ }^{54}$. Michele Tarufo aponta como uma de tais diferenças o fato dos países de Civil Law mais comumente prestigiarem a jurisprudência ao invés do precedente, estabelecendo o autor uma distinção entre os termos. O precedente, reconhecido como fonte normativa em países da Common Law, diria respeito ao julgamento de um único caso primígeno, no qual o tribunal declinaria as razões fáticas e jurídicas de sua decisão, fornecendo uma regra universal (holding) e estabelecendo parâmetros para análises analógicas em casos sucessivos com o objetivo de se determinar se as premissas fáticas seriam de tal forma semelhantes a fim de autorizar a aplicação da

\footnotetext{
${ }^{54}$ TARUFFO, Michele. Precedente e jurisprudência. Revista de Processo, São Paulo, 2011, n. 199, p. 139.
} 
mesma consequência jurídica no processo posterior prevista no precedente. Essenciais para esse sistema, ademais, são as possibilidades de se afastar a aplicação do precedente por se demonstrar que as premissas dos casos seriam distintas (distinguishing), bem assim de se propugnar pela revogação do precedente em razão de mudanças observadas na realidade social (overruling). A jurisprudência, de outro modo, seria o resultado de um conjunto (diferença quantitativa) de decisões consonantes dos tribunais sobre o mesmo tema, das quais se extrairia uma regra jurídica sumarizada que acabaria por se desprender dos fundamentos que levaram à sua aplicação nos julgados.

O julgamento de recuso representativo de recursos repetitivos de certa forma se aproxima do sistema de precedentes, contudo, na Common Law o exame da similitude dos casos se faça após o julgamento daquele que será considerado precedente, enquanto no Brasil a constatação da similitude das questões relevantes dos casos é realizada antes do julgamento e é pressuposto para a seleção de um deles e a suspensão dos demais ${ }^{55}$.

Ao considerarmos as técnicas apontadas, contudo, não parecem caracterizar verdadeiras formas de coletivização de demandas individuais. Ao fixarem orientações jurisprudenciais mais ou menos vinculantes a respeito de questões de direito, permitem certo grau de consistência de interpretação normativa pelos juízes, evitando posicionamentos conflitantes a respeito do conteúdo da lei. Essas orientações, entretanto, não prescindem da propositura de demandas para que sejam aplicadas à resolução dos conflitos, nada obstante tais demandas tenham curso concomitante ou sejam propostas posteriormente.

\subsection{A COLETIVIZAÇÃO DE DEMANDAS INDIVIDUAIS OU PSEUDOINDIVIDUAIS}

Técnica distinta das anteriormente expostas refere-se à transformação, sob o aspecto do regime jurídico aplicável, de uma demanda proposta de forma individual em uma demanda

\footnotetext{
${ }^{55}$ Uma vez que se considera a aproximação do direito pátrio com institutos do direito norte-americano, há de se ponderar a respeito das formas pelas quais naquele país é possível à uma parte desvencilhar o seu caso da aplicação da solução estabelecida no precedente e que de alguma forma devem estar previstas no direito nacional. E elas são basicamente duas: o distiguishing - por meio do qual desqualifica-se a aplicação do precedente demonstrando-se a falta de similitude entre os casos; e o overurrling - que diz respeito à revogação da norma prevista no precedente, permitindo a transformação do direito e a sua adaptação à realidade social em que atua (MARINONI, 2011). Uma das dificuldades enfrentadas pela parte no sistema brasileiro diz respeito justamente à oportunidade de demonstrar que o seu caso se distingue daquele escolhido como paradigma.
} 
coletiva, o que, vale notar desde já, não se encontra expressamente previsto no sistema processual vigente.

O que se está a considerar é a conversão como forma de efetividade processual e conformação do processo ao direito material nos casos em que a medida proposta de forma individual tenha o condão de levar a uma sentença cujos efeitos jurídicos direta ou indiretamente afetem uma coletividade ${ }^{56}$.

A esse respeito, há de se investigar qual a verdadeira natureza da demanda apresentada. Isso porque o fato de ter sido apresentada sob denominação diversa de uma ação coletiva e por um autor individual não necessariamente significa que constitua uma ação individual, em razão da atipicidade do direito de ação.

Ao contrário do direito material, em que vigora o princípio da tipicidade, em razão do qual as situações jurídicas se formam pela subsunção do fato concreto ao fato pressuposto disciplinado na norma, distinguindo-se umas das outras ${ }^{57}$, o direito processual moderno não adota um sistema de ações típicas.

O direito de ação não se altera em razão das circunstâncias em que é exercitado. É considerado um direito genérico e abstrato, sem vinculação com as mais diversas relações de direito material que pode trazer para o processo, desvinculando-se a esfera de direito processual da esfera de direito material. ${ }^{58} \mathrm{Na}$ sua estrutura não guarda correspondência

\footnotetext{
${ }^{56}$ Sérgio Cruz Arenhart propugna pela coletivização em hipóteses mais ampliadas, defendendo que se realizem na generalidade de casos envolvendo interesses individuais homogêneos, configurados sob três critérios: "a) a inviabilidade da formação do contraditório em demanda comum; b) a presunção de afinidade de questões; e c) a existência de utilidade predominante para as partes e para o judiciário no tratamento coletivo dos interesses individuais" (ARENHART, 2013, p. 145). A afinidade a que faz referência é a presença de um ponto comum de fato ou de direito, que corresponde à exigência mínimo para a formação de litisconsórcio. (ARENHART, 2013, p. 148). De acordo com o autor "assim sendo, pode-se concluir que, porque a tutela de interesses individuais é um desdobramento da lógica do agrupamento de demandas (que dá origem à formação do litisconsórcio), também para esta tutela coletivizada a exigência há de ser a presença desse mesmo ponto comum de fato ou de direito. É interessante salientar que, como visto, a figura do litisconsórcio por afinidade de questões se assenta nas mesmas premissas da tutela coletiva de interesses individuais: aproveitar a atividade jurisdicional já realizada e dar tratamento homogêneo à decisão de uma única questão perante o Judiciário" (ARENHART, 2013, p. 150).

${ }^{57}$ COSTA, 2009, p. 123.

${ }^{58}$ Para José Roberto dos Santos Bedaque, "pode-se afirmar tratar-se de um direito absolutamente atípico, pois se destina à veiculação de qualquer interesse assegurado pelo ordenamento jurídico material. (...) A atipicidade do direito de ação vem afirmada no texto constitucional, que ampara, todos os direitos, indistintamente, contra qualquer ameaça ou lesão (art. $5^{\circ}, \mathrm{XXXV}$ )." Para o autor, a ação é única e não comporta adjetivações, as quais ficariam reservadas às tutelas, que constituiriam o elemento típico e variável da demanda. (BEDAQUE, 2009, pp. 71/72).
} 
com o direito material subjacente, tendo por sujeito passivo o Estado, e não o réu, e por objeto a resolução do conflito de interesses. Assim é que representa um direito público do autor em face do Estado, a quem cabe satisfazê-lo por meio do exercício da função jurisdicional. Mesmo que inexistente o direito material alegado pelo autor, terá ele exercido o direito de ação ao obter uma sentença de improcedência. Por consequência, nada obstante a espécie de direito material que a situação concreta envolva, ou mesmo a espécie de tutela pleiteada, o direito de ação será o mesmo ${ }^{59}$.

A atipicidade do direito de ação, todavia, não impede a prática rotineira de se denominar ou qualificar ações em razão da espécie de direito material por elas veiculado (e.g., ação de cobrança de honorários, ação de alimentos e ação indenizatória), da espécie de tutela requerida (e.g., ação condenatória, ação declaratória e ação cautelar) ou mesmo pelo rito ou procedimento a elas atribuído pela lei processual em razão das especificidades das crises que despontam das situações jurídicas submetidas ao Judiciário (e.g., ação ordinária e ação sumária).

Sob uma ótica instrumentalista, as normas de direito processual dão tratamento diferenciado para diferentes demandas em razão de características específicas das situações jurídicas por ela veiculadas, das partes que formam a relação jurídica processual e dos pedidos formulados, sob a égide do princípio da adaptabilidade. ${ }^{60} \mathrm{O}$ Código de Processo Civil, por exemplo, contempla um livro próprio para regular procedimentos especiais, contemplando especificidades de forma a tutelar de forma mais adequada a situação de direito material trazida pelas partes. ${ }^{61}$ Nesse sentido, ao apresentar uma demanda sob a denominação de ação de consignação de pagamento, o autor está a indicar que sua pretensão diz respeito ao cumprimento de uma obrigação de pagar quantia ou coisa por ele devida, de forma que a sua petição inicial deverá contemplar o pedido de depósito do

\footnotetext{
${ }^{59}$ Há quem entenda, entretanto, que a ação rescisória constituiria uma excepcional ação típica, eis que as hipóteses de cabimento são taxativamente fixadas em lei.

${ }^{60}$ COSTA, 2009, p. 125.

61 "A realidade dos conflitos e das variadas crises jurídicas em que eles se traduzem gera a necessidade de instituir procedimentos diferentes entre si, segundo peculiaridades de diversas ordens, colhidos no modo-deser dos próprios conflitos, na natureza das soluções ditadas pelo direito substancial e nos resultados que cada espécie de processo propõe-se a realizar. É perceptível a olho nu, p. ex. A necessidade de diferenciar os procedimentos próprios ao processo de conhecimento, onde se prepara sentença, daqueles que preparam a entrega do bem na execução forçada. No próprio âmbito do processo de conhecimento, o legislador sente a necessidade de oferecer modelos procedimentais diferentes e aplicáveis conforme o caso. Sempre, o procedimento deve ser adaptado à realidade dos conflitos e das soluções buscadas" (DINAMARCO, 2001, pp. 332/333).
} 
objeto da prestação. Não serve o procedimento para anular a dívida em razão de alguma alegada ilicitude, por exemplo. Caso se ajuíze demanda sob essa nomenclatura mas com pedido de anulação da dívida ao invés de pagamento, a consequência será apenas de que não se seguirá o procedimento específico da consignação em pagamento. ${ }^{62}$ Considera-se, assim, juridicamente irrelevante o nomem iuris dado à ação pelo autor, devendo se dar ao processo o regime aplicável de acordo com as características da demanda apresentada.

Em suma: (i) o nome dado à demanda pelo autor não tipifica o direito de ação por ele exercido, eis que o direito de ação é atípico ${ }^{63}$; e (ii) não é o nome, mas as características da demanda que são relevantes para a determinação da espécie de medida proposta e o regime jurídico processual a ela aplicável.

O fato de uma ação restar proposta como uma ação coletiva, não quer dizer que efetivamente se trate de uma ação coletiva. Do mesmo modo, a propositura de uma demanda sob roupagem individual pode, na verdade, representar o ajuizamento de uma demanda coletiva. Isso não quer dizer que cada situação contemple um direito de ação diverso, inexistindo ações típicas mesmo no que se refere às diferentes formas de ações coletivas $^{64}$. A determinação da real natureza da demanda é, todavia, relevante para que a ela se dê o tratamento processual adequando conforme definido na lei, inclusive com a aplicação dos institutos processuais próprios a cada figura, como no que toca à legitimidade e à coisa julgada.

Conforme abordado alhures, em termos gerais, as ações coletivas são aquelas que têm por objeto a defesa de interesses coletivos em sentido lato. ${ }^{65}$ Há quem entenda que a

\footnotetext{
${ }^{62}$ No recurso especial $\mathrm{n}^{\mathrm{o}}$ 860.660, decidido monocraticamente pelo Ministro Antonio Carlos Ferreira, o Superior Tribunal de Justiça decidiu que: "Tendo sido tecido na exordial pedido de revisão do contrato de financiamento habitacional celebrado entre as partes, irrelevante é o fato de ação ter sido denominada consignação em pagamento, impondo-se o exame do feito nos termos em que colocados".

63 "Todavia, independentemente do rito procedimental adotado, o direito de ação continua a ser o mesmo, não sujeito a qualquer espécie de tipificação. O direito de ação permanece genérico e abstrato, qualquer que seja o procedimento previsto em lei para o processo que dará origem, quando exercido. Seja em processo de rito sumário, rito ordinário ou procedimento especial, o direito de ação é atípico. Esse raciocínio vale tanto para as demandas individuais, quanto para as demandas coletivas. Ainda que se busque a tutela de interesse geral, difuso ou coletivo, o direito de ação é um só." (COSTA, 2009, p. 125).

${ }^{64}$ COSTA, 2009, p. 126.

${ }^{65}$ Ressalvando a ação coletiva passiva, que não integra o objeto deste estudo e o caso da totalidade dos membros da coletividade em questão estiver nominalmente presente na relação jurídica processual.
} 
determinação da natureza do processo se faça pela análise do seu objeto ${ }^{66}$, ou seja, da tutela pleiteada. ${ }^{67}$ Antonio Gidi, entretanto, argumenta ser tal entendimento equivocado, sendo necessário verificar a causa de pedir apresentada na demanda. Exemplifica com o caso de uma propaganda enganosa que indevidamente associa o produto anunciado a produto de outra empresa de superior qualidade e melhor reputação no mercado. A ação proposta pela empresa concorrente será individual, eis que se baseará unicamente no seu direito subjetivo, por mais que provoque a retirada da propaganda e proporcione a tutela do interesse difuso pertinente de forma acidental. ${ }^{68}$ A ação assim proposta é baseada no direito de preservação de sua marca e clientela, enquanto eventual ação coletiva teria fundamento no direito do consumidor de não ser ludibriado. Eventuais decisões díspares dos processos não ocasionariam um conflito prático de julgados, pois seriam produzidas em bases diversas.

Para o mencionado autor, "o critério científico para identificar se determinado direito é difuso, coletivo, individual homogêneo ou individual puro não é a matéria, o tema, o assunto abstratamente considerados, mas o direito subjetivo específico que foi violado" ${ }^{69}$.

Kazuo Watanabe define a questão de forma precisa. A determinação da abrangência da ação se faz por meio da correta fixação do objeto litigioso do processo, ou seja, o pedido e a causa de pedir. Se o autor expõe como causa de pedir um direito difuso ou coletivo e formula pedido de tutela coletiva, estar-se-á diante de uma demanda coletiva ${ }^{70}$.

A questão é que, em casos de lides sociológicas com dimensão coletiva, por vezes, a demanda veiculada por um sujeito tem por base um direito subjetivo individual, mas que se refere a uma relação jurídica substancial de caráter incindível. Tal fenômeno decorre do

\footnotetext{
${ }^{66} \mathrm{O}$ objeto do processo constitui tema de estudo dos processualistas alemães, representando para eles o núcleo metodológico das discussões a respeito do processo, enquanto os seguidores da tradição processualista italiana centralizam sua atenção no instituto da ação. No Brasil, segue-se esta última orientação, adotando-se a teoria eclética de Liebman e as condições da ação como elementos essenciais ao direito de ação e como um dos requisitos para o exame do mérito da demanda. Nesse contexto, apesar de não abundarem estudos na doutrina nacional a respeito do objeto do processo, prevalece o entendimento que o equipara à pretensão processual, ou seja, ao pedido do autor, composto pelo pedido imediato - a tutela jurisdicional requerida do Estado para resolver o conflito de interesses - e pelo pedido mediato - o bem da vida que se pretende obter por meio do processo. Logo, como pretensão processual, o objeto do processo abrange o bem da vida requerido pelo autor, bem assim o tratamento que se requer lhe seja dispensado pelo Estado-juiz. (COSTA, 2009, pp. 140/141)

${ }^{67}$ É o que entende Nelson Nery Júnior, segundo exposição de Antonio Gidi (GIDI, 1995, p. 21).

${ }^{68}$ GIDI, 1995, p. 21.

${ }^{69}$ GIDI, 1995, p. 21.

${ }^{70}$ WATANABE, 2011, pp. 77/78.
} 
fato dos interesses difusos e coletivos possuírem uma dimensão pessoal, de forma a que o seu atendimento proporcione benefício para os membros do grupo, na mesma forma que a sua violação a todos prejudica. Rodolfo de Camargo Mancuso reconhece a possibilidade de que um interesse difuso venha a ser externado por um sujeito ou uma entidade em um caso concreto, sem que com isso, entretanto, deixe de ser difuso para se tornar individual ${ }^{71}$.

Recorde-se, a esse respeito, o caso da anulação de deliberação assemblear de interesse geral de sociedade anônima promovida por um dos acionistas que tenha supostamente experimentado prejuízos diretos. Tratando-se a deliberação de um ato jurídico único e incindível, de modo a atingir todos os acionistas, sua anulação necessariamente produzirá efeitos com relação a todos eles, não se concebendo a possibilidade de valer para alguns e não para outros.

Nesse caso, considerando que a deliberação causou prejuízo a todos os acionistas, despontará um interesse coletivo no sentido de desfazer o ato. Tem-se, aqui, um interesse compartilhado por uma pluralidade de pessoas (acionistas), vinculados por uma relação jurídica-base (a qualidade de acionistas), recaindo sobre um objeto indivisível (a invalidade da deliberação). Apesar disso, reconhece-se o direito subjetivo de cada um com relação à deliberação ${ }^{72}$.

A demanda individual buscando a tutela desse seu direito subjetivo assumiria, assim, contornos coletivos na medida em que não se admitiria demandas semelhantes de outros sujeitos na mesma posição sob o risco de acarretarem em um conflito prático entre julgados $^{73}$. Não poderia ser válida a deliberação para uns e inválida para outros, eis que se trata de uma única relação jurídica.

\footnotetext{
${ }^{71}$ MANCUSO, 2004, p. 95.

72 BARBOSA MOREIRA, José Carlos. A Ação Popular do Direito Brasileiro como Instrumento de
} Tutela Jurisdicional dos Chamados "Interesses Difusos" in Temas de Direito Processual: primeira série. 2. ed. Saraiva: São Paulo, 1988. p. 111.

73 "Uma das dificuldades consiste em saber se as pretensões deduzidas em juízo são efetivamente individuais, ou seja, se a relação jurídica de direto substancial a que essas pretensões estão referidas admite a formulação de vários pedidos individualizados da mesma espécie, ou se, acaso pela sua natureza e peculiaridade, é ela de natureza incindível, de modo que, em princípio, são inadmissíveis postulações individuais." (WATANABE, Kazuo. Relação entre Demanda Coletiva e Demandas Individuais. In GRINOVER, Ada Pellegrini; MENDES, Aluisio Gonçalves de Castro; WATANABE, Kazuo (coord.). Direito Processual e o Anteprojeto de Código Brasileiro de Processos Coletivos. São Paulo: Revista dos Tribunais, 2007, p. 156). Cândido Rangel Dinamarco, entretanto, entende que nessa hipótese ficaria afastado o risco do conflito prático entre julgados, eis que se o demandante fosse sucumbente, os demais poderiam mover a ação sem sofrer qualquer 
Trata-se, na realidade, de hipótese de litisconsórcio unitário, na medida em que são "incindíveis as situações jurídicomateriais que figuram como res in judicio deducta" ${ }^{74}$. Segundo Cândido Rangel Dinamarco, isso importa dizer que a relação jurídica controvertida é indivisível, de modo a levar a uma necessária homogeneidade de julgamento de mérito.

Por se tratar de caso de litisconsórcio unitário, consequentemente também se configuraria hipótese de litisconsórcio necessário, em razão da indivisibilidade do objeto. ${ }^{75}$ De acordo com o autor:

A mesma ideia de direito indivisível, ou de relação jurídica incindível, que tem servido para distinguir as situações conducentes ao litisconsórcio unitário, e o mesmo critério prático que exclui a admissibilidade de julgados conflitantes - todos esses pontos de referência devem servir, em princípio, como critério para determinar também a necessidade do litisconsórcio (supra, n. 65): se absurdo há em conceber uma sentença que julgasse procedente a ação de nulidade de casamento proposta pelo Ministério Público quanto ao réu varão e improcedente quanto à mulher, o mesmo absurdo haverá também no julgamento de semelhante demanda perante um dos cônjuges apenas, sem que o outro seja parte no processo $^{76}$.

O fato é que em se tratando de direitos difusos e coletivos, marcados pela indeterminação ou indeterminabilidade de titulares, bem assim pela tendência de se encontrarem dispersos, serem numerosos e, no mais das vezes, não possuírem relevantes incentivos materiais e

prejuízo. Se vencedor fosse, aos demais não despontaria interesse processual para promover nova demanda. (DINAMARCO, 2009, pp. 224/225).

${ }^{74}$ DINAMARCO, Cândido Rangel. Litisconsórcio. 8. ed., ver. e atual., São Paulo: Malheiros, 2009, p. 78

${ }^{75}$ Segundo Giuseppe Chiovenda: "Quando, ao contrário, a ação tende à mudança de uma relação ou estado uno, não se pode propor senão em face a todos os partícipes da relação ou estado; porque o que existe como unidade composta de vários não pode deixar de existir como unidade senão relativamente a todos: a sentença que opera a mudança (sentença constitutiva, adiante, $\S 8$ ) deve operá-la para todos os componentes; de outra forma inutiliter datur. Por exemplo: a instância para a divisão deve propor-se contra todos os herdeiros ou condôminos (CPC, art. 882). Outros exemplos estão esparsos na lei (CC, arts. 104 e 1.525; CPC, arts. 611, 721, 730 etc.). Aí, o litisconsórcio é necessário (supra, nº 18)." (CHIOVENDA, 1998, p. 225).

76 DINAMARCO, 2009, pp. 189/190. 
culturais para atuarem conjuntamente em juízo, o litisconsórcio entre todos seria assaz inviável ou até mesmo impossível. Exigir o litisconsórcio seria o mesmo que negar o acesso $^{77}$.

Os efeitos nocivos da possibilidade da propositura individual de ações desse jaez assume maior dimensão ao se considerar o fenômeno dos processos repetitivos. Nesse caso, centenas ou milhares de demandas com objeto sobreposto poderiam ser ajuizadas, inclusive com a concomitância de ações coletivas e ações nominalmente individuais. A esse respeito, menciona-se a respeito da cultura individualista e da tendência da universalização da jurisdição, reduzindo-se os custos do processo e eliminando-se entraves jurídicos para a propositura de demandas individuais ${ }^{78}$.

Kazuo Watanabe é categórico a esse respeito:

ações individuais que veiculem a mesma pretensão da ação coletiva
ou de uma outra ação individual com o mesmo escopo são
inadmissíveis por significarem um bis in idem, que poderá dar
origem a conflitos práticos, e não apenas lógicos, de julgados, o

77 Cândido Rangel Dinamarco ressalta que os casos de litisconsórcio necessário são excepcionais, por importarem "restrição ao poder de agir em juízo", não se admitindo o julgamento do mérito do processo sem que dele tenham participado os litisconsortes (DINAMARCO, 2009, p. 246). Tratando-se de litisconsórcio necessário ativo, o campo de admissibilidade é ainda mais reduzido, havendo parte da doutrina que sequer entende ser cabível (DIDIER JUNIOR, Fredie. Litisconsórcio necessário ativo(?). In: MOREIRA, Alberto Camiña; ALVAREZ, Anselmo Prieto; BRUSCHI, Gilberto Gomes (Coord.). Panorama atual das tutelas individual e coletiva: estudos em homenagem ao professor Sérgio Shimura. São Paulo: Saraiva, 2011, p. 401-410). Além de constituir um empecilho ao acesso à justiça por condicionar o exercício do direito de ação a que outro o exerça conjuntamente, a imposição da participação desse terceiro como demandante feriria a liberdade de agir ou de não agir. Nesse tocante, afirma Cândido Rangel Dinamarco "Realmente, ninguém pode ser compelido a agir em juízo, sendo autor ou exequente contra sua própria vontade. Esse autêntico dogma corresponde à tradição que nos vem das fontes mais cristalinas e incontrastadas. É princípio no direito romano a liberdade de agir em juízo e geral a assertiva de que ou o litisconsórcio se forma, quando necessário, ou o juiz deve 'respingere la domanda non proposta da tutti o contro tutti' - ou de que 'o direito, tradicionalmente, é avesso a constranger alguém a demandar como autor"'. E continua: "A conveniência do resultado jurídico-substancial postulado não pode ser sentida da mesma forma por todos os cotitulares da mesma situação jurídica incindível. Cada um deles tem todo o direito, no plano do direito material, de preferir manter o status quo ante; tem também a prerrogativa de formar seu próprio juízo de conveniência quanto ao momento, modo e estratégias para uma iniciativa processual." (DINAMARCO, 2009, p. 261 e 267). Apesar de apontar a tendência de restrição no direito processual brasileiro do litisconsórcio necessário ativo, o autor reconhece a existência de algumas poucas circunstâncias em que se aplicaria, envolvendo situação jurídica incindível na qual duas ou mais pessoas detivessem apenas em conjunto a legitimidade para a realização de atos relevantes para todas elas. Aplicando-se o raciocínio na esfera coletiva, teria-se como esse legitimado o substituto processual.

${ }^{78}$ Nesse tocante, observa Cândido Rangel Dinamarco a admissão em juízo da tutela por iniciativa individual dos chamados interesses legítimos, os quais, em tese, sequer configurariam direito subjetivo de tais sujeitos. 
que o nosso ordenamento jurídico não tolera (daí os institutos da litispendência e da coisa julgada) ${ }^{79}$.

Sob essa ótica, uma ação individual em que a relação jurídica substancial que lhe dá fundamento e sobre a qual o provimento jurisdicional pleiteado deverá atuar em termos práticos seja de natureza coletiva, unitária e incindível, será, na realidade, uma ação pseudo-individual $^{80}$, vez que o seu resultado beneficiará todos os membros da coletividade que faz parte dessa relação.

Na prática, a tarefa de identificar a real natureza da relação jurídica substancial, entretanto, no mais das vezes, apresenta considerável grau de dificuldade, não restando claramente expressa nas razões consignadas na peça inicial. Isso porque a situação individual apresentada na ação pode ser uma manifestação, um prolongamento ou uma decorrência de uma situação coletiva da qual faz parte, mas que pode não restar evidente ${ }^{81}$.

De qualquer modo, ressalta o autor que não poderiam coexistir mais de um processo com esse objeto, vez que veiculariam a mesma pretensão, operando-se os efeitos da litispendência e restando afastada a aplicação do artigo 104 do Código de Defesa do Consumidor na medida em que em ambos os processos a pretensão seria de natureza coletiva.

\footnotetext{
${ }^{79}$ WATANABE, 2007, p. 157.

${ }^{80}$ Expressão cunhada por Kazuo Watanabe (WATANABE, 2007, p. 156-160).

${ }^{81}$ Para ilustrar seu posicionamento, Kazuo Watanabe faz menção ao recente caso das milhares de ações judiciais movidas por todo o país para questionar a cobrança de tarifa básica mensal referente a disponibilização de serviço telefônico fixo comutado (STFC). Nesses processos, usuários do serviço questionavam as cláusulas dos contratos entabulados com as concessionárias que previam o pagamento de uma tarifa mínima mensal pela mera disponibilização do serviço, ainda que não houvesse uso efetivo. Por mais que na aparência os processos entre usuários e prestadoras se restringissem à discussão da validade de cláusulas contratuais em relações individuais havidas entre os autores e réus, para o processualista, uma vez que tais contratos retratam a política tarifária unificada da União consubstanciada nos contratos de concessão, bem assim porque a Lei Geral de Telecomunicações, nos seus artigos 106 e 107, estabelece a isonomia entre os usuários dos serviços concedidos a respeito das tarifas cobradas, não seria admissível que houvesse a alteração de uma situação individual sem que se reproduzisse tal alteração para todos os demais assinantes de todas as demais concessionárias, de forma que qualquer mudança devesse ser feira de forma global e uniforme, jamais individual e diversificada. Cada situação individual, na realidade, referiria-se a uma mesma relação jurídica substancial incindível. (WATANABE, 2007, pp. 158/160). Ainda a respeito da cobrança da assinatura básica, o Ministro Luiz Fux, então no Superior Tribunal de Justiça, no julgamento do Conflito de Competência $\mathrm{n}^{\mathrm{o}} 47.107$, expressou seu entendimento de que a demanda possuiria natureza transindividual, em que pese buscar tutelar diretamente apenas o interesse individual do consumidor que figurava no polo ativo da ação.
} 
O risco dos processos múltiplos, além da redundância e ineficiência, seria a produção de decisões contraditórias que não poderiam praticamente coexistir no ordenamento. Conforme frisa Kazuo Watanabe:

A conclusão que se impõe, à vista dessas considerações, é no sentido de que as ações individuais que veiculem a mesma pretensão da ação coletiva ou de uma outra ação individual com o mesmo escopo são inadmissíveis por significarem um bis in idem, que poderá dar origem a conflitos práticos, e não apenas lógicos, de julgados, o que nosso ordenamento jurídico não tolera (daí os institutos da litispendência e da coisa julgada) ${ }^{82}$.

Segundo o raciocínio desenvolvido, não se admitiria que essas questões de natureza incindível e unitária recebessem tratamento atomizado, de forma que o tratamento mais adequado a lhes ser dispensado seria por meio de ação coletiva. Por mais que entenda serem inadmissíveis ações individuais para a tutela da matéria de tal índole, afirma Kazuo Watanabe que de outro modo somente poderiam ser cabíveis se proporcionassem o tratamento globalizado da matéria. Outra alternativa, apesar de inapropriada tecnicamente, mas com o efeito prático semelhante, seria o prosseguimento de um processo, preferencialmente o promovido de forma coletiva, e a suspensão dos demais ${ }^{83}$.

Vozes na doutrina posicionam-se contrariamente à vedação do acesso à Justiça a essas demandas individuais. Para Fredie Didier Junior e Hermes Zaneti Junior:

O que surpreende, e com o que, desde logo discordamos, é com a vedação da tutela dos direitos em seu reflexo individual. Por certo a tutela coletiva se apresenta, em muitos casos, como a mais adequada. Aliás, essa é a conclusão óbvia que ampara o princípio

\footnotetext{
${ }^{82}$ WATANABE, 2007, p. 157.

83 "A solução que seria mais apropriada, em nosso sentir, na conformidade das ponderações acima desenvolvidas, seria a proibição de demandas individuais referidas a uma relação jurídica global incindível. Porém, a suspensão dos processos individuais poderá, e termos práticos, produzir efeitos bem próximos da proibição, se efetivamente for aplicada pelo juiz da causa." (WATANABE, 2007, p. 160).
} 
da primazia da tutela coletiva sobre a individual, ao qual nos referiremos no próximo capítulo ${ }^{84}$.

A situação, de fato, é espinhosa e envolve considerações contrapostas. Denegar a possibilidade da propositura individual de demanda que tenha por objetivo a defesa de interesse próprio, por mais que com repercussão coletiva, representa limitação à universalidade da jurisdição. Permitir que tal demanda seja processada de maneira individual, por mais que veicule conteúdo coletivo, pode acarretar a multiplicação de processos repetitivos e a potencialidade de decisões contraditórias.

A solução pode se dar por meio do gerenciamento do processo pelo juiz. ${ }^{85}$ Isso importaria conceder ao magistrado o poder de privilegiar o julgamento da demanda coletiva ao julgamento das individuais, determinando a suspensão de todas as demandas desta natureza, independentemente de requerimento da parte, até que aquela fosse julgada, de forma a que a sentença proferida na demanda coletiva influenciasse as demandas individuais.

No Rio Grande do Sul, medida nesse sentido foi tomada com relação a processos promovidos com relação a expurgos inflacionários atinentes a valores aplicados em cadernetas de poupança com relação a certos planos econômicos. Mais de oitenta mil ações individuais foram propostas, mas acabaram suspensas pelos juízes, independentemente de requerimento das partes, até o julgamento de dez ações coletivas que tinham curso no

${ }^{84}$ DIDIER JUNIOR, Fredie; ZANETI JUMIOR, Hermes. Curso de Direito Processual Civil, vol. 4. 8. ed. Salvador: Juspodvm, 2013, p. 97. No mesmo sentido, Bruno Gomes Borges da Fonseca e Carlos Henrique Bezerra Leite afirmam: "A inadmissão das ações pseudoindividuais, talvez, a saída imediata e mais simplista, entre outros efeitos, poderá ocasionar restrição à garantia de acesso à Justiça. $\mathrm{O}$ seu recebimento como demanda eminentemente individual parece dificultoso, pois a causa de pedir e o pedido apontam para outro caminho. Além disso, a indivisibilidade do objeto importa laços de incindibilidade. Outra alternativa é admiti-la como pretensão coletiva, mas, nessa hipótese, haveria o óbice da suposta ilegitimidade ativa do indivíduo para propor ações coletivas" (FONSECA, Bruno Bomes Borges da; LEITE, Carlos Henrique Bezerra. Acesso à Justiça e Ações Pseudoindivduais: (I)legitimidade Ativa do Indivíduo nas Ações Coletivas. Revista de Processo, vol. 203, ano 37, janeiro 2012, p. 354)

85 "Case management, em suma, é uma atividade processual que fortalece o controle judicial sobre: (a) identificação das questões relevantes, (b) maior utilização pelas partes de meios alternativos de solução de controvérsias e (c) programação do tempo necessário para a conclusão adequada de todos os passos processuais. $\mathrm{O}$ juiz planeja o processo e disciplina o calendário com a colaboração das partes. Pelo contato frequente que mantém com as partes e destas entre si, há a facilitação da solução amigável da controvérsia. E mesmo não ocorrendo o acordo, as técnicas do case management possibilitam ao juiz a eliminação das questões despiciendas e o planejamento do processo de modo a fazê-lo caminhar para o julgamento final (trial) com eficiência e sem custo exagerado." (WATANABE, 2013, p. 8). 
tocante ao mesmo objeto litigioso ${ }^{86}$. Com o julgamento de procedência das demandas coletivas, as individuais foram convertidas em liquidação individual, de forma a que cada sujeito restasse apenas comprovar que estava inserido naquela coletividade, ou seja, que manteve saldo em poupança no período em questão, bem assim o montante indenizatório ${ }^{87}$.

\author{
Medida nesse sentido vinha prevista no Anteprojeto de Código Brasileiro de Processos \\ Coletivos, que no parágrafo $3^{\circ}$ do artigo $6^{\circ}$, dispunha:
}

O Tribunal, de ofício, por iniciativa do juiz competente ou a requerimento da parte, após instaurar, em qualquer hipótese, o contraditório, poderá determinar a suspensão de processos individuais em que se postule a tutela de interesses ou direitos referidos a relação jurídica substancial de caráter incindível, pela sua própria natureza ou por força de lei, a cujo respeito as questões

\footnotetext{
86 "A Vice-Coordenadoria Cível de Porto Alegre constituiu uma comissão ao desenvolvimento de plano de ação focado na valorização das demandas coletivas. Deu-se, então, a sugestão de decisão suspensiva das ações individuais, baseada nas seguintes premissas: (a) há prejudicial externa (letra "a", inciso IV, do artigo 265 do CPC) na medida em que a ação civil pública trata da mesma matéria e de conteúdo mais amplo, (b) evitar-se-á decisões conflitantes entre essa lide e a ação noticiada, com imenso descrédito do Poder Judiciário, (c) prejuízo algum terá a parte autora, quando poderá obter título executivo para simples liquidação e posterior execução, o que abrevia seu pleito, (d) o processo é de natureza instrumental e desmerece processar e julgar mesma lide que está albergada na ação civil pública, o que leva à ilógica do sistema processual pátrio, malferindo o princípio constitucional da economicidade - ex vi "modelo de decisão para suspensão" remetido aos magistrados através do Ofício-Circular 318/07-CGJ." Projeto Poupança. Disponível em http://www.premioinnovare.com.br/praticas/projeto-poupanca-2208/. Acessado em 30 de dezembro de 2013.

${ }^{87} \mathrm{O}$ caso da suspensão chegou, em razão do inconformismo de uma das autoras individuais, ao Superior Tribunal de Justiça por meio do Recurso Especial 1.110.549-RS, sob a Relatoria do Ministro Sidnei Beneti. Manteve-se, contudo, a suspensão. No entendimento expresso pelo relator, aplicando analogamente a Lei dos Recursos Repetitivos: "No atual contexto da evolução histórica do sistema processual relativo à efetividade da atividade jurisdicional nos Tribunais Superiores e nos próprios Tribunais de origem, as normas processuais infraconstitucionais devem ser interpretadas teleologicamente, tendo em vista não só a realização dos direitos dos consumidores mas também a própria viabilização da atividade judiciária, de modo a efetivamente assegurar o disposto no art. 81 do Código de Defesa do Consumidor, de forma que se deve manter a orientação firmada no Tribunal de origem, de aguardo do julgamento da ação coletiva, prevalecendo, pois, a suspensão do processo, tal como determinado pelo Juízo de $1^{\circ}$ Grau e confirmado pelo Acórdão ora recorrido. Atualizando-se a interpretação jurisprudencial, de modo a adequar-se às exigências da realidade processual de agora, deve-se interpretar o disposto no art. 81 do Código de Defesa do Consumidor, preservando o direito de ajuizamento da pretensão individual na pendência de ação coletiva, mas suspendendo-se o prosseguimento desses processos individuais, para o aguardo do julgamento de processo de ação coletiva que contenha a mesma macro-lide. (...) O direito ao ajuizamento individual deve também ser assegurado, no caso de processos multitudinários repetitivos, porque, se não o fosse, o autor poderia sofrer consequências nocivas ao seu direito, decorrentes de acidentalidades que levassem à frustração circunstancial, por motivo secundário, do processo principal, mas esse ajuizamento não impede a suspensão. (...) Mas a faculdade de suspensão, nos casos multitudinários abre-se ao Juízo, em atenção ao interesse público de preservação da efetividade da Justiça, que se frustra se estrangulada por processos individuais multitudinários, contendo a mesma e única lide, de modo que válida a determinação de suspensão do processo individual, no aguardo do julgamento da macro-lide trazida no processo de ação coletiva.".
} 
devam ser decididas de modo uniforme e globalmente, quando houver sido ajuizada demanda coletiva versando sobre o mesmo bem jurídico ${ }^{88}$.

O principal problema da prática é a de pressupor a propositura de uma demanda coletiva, sem a qual os processos individuais não se suspenderiam.

Outra técnica é a da extensão subjetiva da coisa julgada, a qual também teria o efeito de evitar decisões conflitantes. A esse respeito, Cândido Rangel Dinamarco preleciona:

Se bem busquem seu objetivo por vias diversas, existindo mesmo 'um nexo de alternatividade e recíproca exclusão entre litisconsórcio necessário e alargamento da coisa julgada', é inegável que ambos são preordenados à mesma finalidade de evitar julgados conflitantes. Diante de hipóteses de duas ou mais relações jurídicas íntima e incidivelmente conexas, ao legislador cabe a escolha entre impor a coligação litisconsorcial de seus titulares e permitir a demanda individual mas estender ao não-participante os efeitos da sentença e a autoridade da coisa julgada que vier a se abater sobre ela ${ }^{89}$.

Para José Carlos Barbosa Moreira, a técnica é aplicável no citado caso da anulação da deliberação da sociedade anônima, reconhecendo-se ao demandante a qualidade de representante dos acionistas ausentes da ação ${ }^{90}$.

Em outras hipóteses de litisconsórcio unitário o sistema proporcionaria técnicas com vistas a evitar o litisconsórcio necessário, tais como a substituição processual, por meio da qual um dos litigantes passaria a representar o outro de forma a tornar-se prescindível sua participação direta no processo - técnica esta fundamental às ações coletivas. A esse respeito, esclarece Susana Henriques da Costa:

\footnotetext{
${ }^{88}$ WATANABE, 2007, p. 160.

${ }^{89}$ Entendimento esse compartilhado por José Rogério Cruz e Tucci (TUCCI, José Rogério Cruz e. Limites subjetivos da eficácia da sentença e da coisa julgada. São Paulo: RT, 2007), fazendo alusão à doutrina de Allorio (1992).

${ }^{90}$ Essa é a posição de José Carlos Barbosa Moreira, conforme exposta por Camilo Zufelato. (ZUFELATO, Camilo. Coisa Julgada Coletiva. São Paulo: Saraiva, 2011, pp. 132/135.
} 
O litisconsórcio em ação civil pública, ainda, em função da própria natureza jurídica incindível da relação jurídica de direito material, será sempre unitário, de forma que os efeitos da decisão serão obrigatoriamente os mesmos para todos. Os interesses metaindividuais são indivisíveis e não permitem a emissão de decisões diferentes a cada um dos legitimados. [...] É de se salientar, portanto, que o litisconsórcio em ação civil pública configura hipótese excepcional de litisconsórcio unitário facultativo. Realmente, em virtude do princípio do contraditório, a regra é a que, todas as vezes que a relação jurídica de direito material não puder ser cindida, seja necessária a presença de todos os seus titulares na relação jurídica processual, até porque todos serão atingidos pelos efeitos da decisão. Em outros termos: a regra é que o litisconsórcio unitário seja também necessário. [...] Nos casos de processos versando sobre interesses metaindividuais, entretanto, apesar da insensibilidade da relação jurídica de direito material, não será necessária a presença no polo ativo da demanda de todos os legitimados (como já visto, a legitimidade é concorrente e disjuntiva). Isso decorre do fato de que a legitimidade, em tais casos, é extraordinária, ou seja, o autor da demanda não é o suposto titular do direito material veiculado nos autos, mas, sim, substituto processual do verdadeiro titular (defende em nome próprio, direito alheio). Assim, não há prejuízo ao princípio do contraditório, desde, é claro, que todos aqueles que eventualmente venham a ser atingidos pelo decidido no processo tenham sido adequadamente representados pelo legitimado ou legitimados ${ }^{91}$.

Daí porque o mecanismo de conversão da demanda pseudo-individual em demanda coletiva representa uma forma adequada de equacionar a questão, congregando as técnicas da substituição processual e da extensão da coisa julgada.

\footnotetext{
${ }^{91}$ COSTA, 2010, p. 636.
} 
Foram as ações coletivas concebidas e estão aparelhadas para o tratamento de interesses metaindividuais, com pressupostos e garantias aptos a legitimar a produção de provimentos generalizantes com eficácia ampliada e com a autoridade da coisa julgada estendendo-se erga omnes ou ultra partes.

A coletivização de uma demanda individual, assim, importaria a transformação de um processo individual em coletivo de modo que a sentença a ser proferida não se limite a tutelar o interesse individual do demandante original, mas também o interesse metaindividual associado, com eficácia e formando coisa julgada na esfera coletiva.

Fenômeno desse jaez é observado na Common Law nos Estados Unidos e na Inglaterra com relação às class actions. No processo norte-americano, uma ação assume caráter coletivo por decisão judicial, mediante requerimento de uma das partes, recebendo a chamada certification. Para tanto, a ação poderá ter sido proposta pelo demandante em seu nome e no nome da classe ou mesmo em nome individual apenas, permitindo-se a uma das partes pleitear posteriormente a inclusão da classe como representada ${ }^{92}$.

Caso não se entendam presentes os requisitos para a class action, tramitará a ação de forma individual $^{93}$. Na Inglaterra, há os processos por representação, a respeito dos quais, conforme as rules atuais, quando mais de uma pessoa tem o mesmo interesse em uma causa, a ação poderá se iniciar ou "(b) o tribunal pode ordenar que a ação prossiga em conjunto com ou contra mais pessoas que tenham os mesmos interesses, no papel de representantes de quaisquer outras pessoas que compartilhem tal interesse" 94 .

92 GIDI, Antonio. A class action como instrumento de tutela coletiva dos direitos: as ações coletivas em uma perspectiva comparada. São Paulo: Revista dos Tribunais, 2007, p. 195.

93 A esse respeito, Antonio Gidi preleciona: "Se o juiz indeferir o requerimento de certificação da ação coletiva, ela não será extinta, mas prosseguirá como uma ação individual entre o autor (já não mais representante) e o réu. Em alguns casos, mesmo que a ação individual não seja cabível, a ação coletiva poderá continuar se o representante for substituído. É como se duas ações independentes (a coletiva e a individual) convivessem em um mesmo procedimento." E continua: "Essa disciplina dada à matéria pelo direito americano, dividindo o procedimento da ação coletiva em duas fases, é consistente com a complexidade do fenômeno e superior à forma simplista com que o direito brasileiro trata a matéria. A flexibilidade e a economia processual atingidas com tal sistema são fundamentais para a efetividade do instituto no direito americano." (GIDI, 2007, p. 193).

${ }^{94}$ De acordo com Neils Andrews, contudo, esses processos por representação são instaurados de forma excepcional na Inglaterra em razão de um posicionamento restritivo dos tribunais a respeito do seu cabimento, bem assim em razão dos custos que o autor individual, que passa a ser representante da classe, tem que suportar sem garantias de que será reembolsado mesmo se sua demanda for julgada procedente 
Antonio Gidi afirma que tal fenômeno não é admissível no direito processual brasileiro, pois, por aqui:

ou se propõe uma ação coletiva, ou se propõe uma ação individual. As duas esferas são incomunicáveis. Se uma ação coletiva é proposta em situação que não permita a tutela coletiva, a ação será simplesmente extinta. Não é dado ao juiz nem às partes transformar a ação individual, mesmo porque o legitimado a promover uma ação coletiva geralmente não possui qualquer pretensão própria contra o réu e, muitas vezes, não tem legitimidade para representar o membro do grupo em ação individual. O inverso também é verdadeiro: no Brasil, uma ação individual não pode ser 'promovida' a ação coletiva por ordem do juiz, ainda que ela seja em tese cabível ${ }^{95}$.

A técnica de coletivização, se admissível, pode representar um mecanismo de aproveitamento de um processo individual (ou pseudo-individual) para que nele os interesses sejam tratados de forma coletiva, aplicando-se os institutos e princípios processuais relativos às ações coletivas. A coletivização, entretanto, não é suficiente por si só para evitar a proliferação de processos e as mazelas daí decorrentes, haja vista a incapacidade das ações originalmente coletivas de impedir tal resultado. Por isso é que se revela importante que a pendência de uma ação coletiva (tenha sido proposta como tal ou seja nela transformada) impeça que novas ações individuais ou coletivas veiculando as mesmas pretensões sejam processadas e julgadas em paralelo com a potencialidade de se produzirem decisões conflitantes ou inconsistentes. Daí porque em associação à técnica da coletivização, faz-se necessário a aplicação dos efeitos da litispendência e da coisa julgada, bem como o gerenciamento processual pelo juiz, de modo a, por exemplo, suspender ações individuais em curso.

(ANDREWS, Neil. O Moderno processo civil: formas judiciais e alternativas de resolução de conflitos na Inglaterra. Orientação e revisão da tradução por Teresa Arruda Alvim Wambier. São Paulo: RT, 2010, p 339).

${ }^{95}$ GIDI, 2007, p. 192. 


\subsection{A LEGITIMIDADE INDIVIDUAL PARA A AÇÃO COLETIVA}

No direito processual pátrio vigente, de início se identificaria um óbice à transformação, concernente à legitimidade ativa para a causa. Isso porque o autor individual não é parte legítima a propor ação civil pública, de forma diversa das class actions, nas quais o membro da classe possui legitimidade, mas se sujeitando ao exame da representatividade adequada no caso concreto. ${ }^{96}$ Em linha com o sistema vigente, assim, exigir-se-ia que um ente legitimado adotasse a demanda individual, ingressando no processo em litisconsórcio ativo ulterior.

Em princípio, entretanto, não haveria impedimento para que, de lege ferrenda, em casos determinados, fosse o autor individual legítimo para defender o grupo de que é membro, respeitando-se critérios para a apuração da representatividade adequada, inclusive no que diz respeito às condições de tal sujeito de conduzir processualmente a defesa dos interesses coletivos de forma apropriada.

Curioso notar que no Brasil admite-se a legitimidade da pessoa natural para a proteção de interesse geral com relação ao qual ela não derivará nenhum benefício pessoal direto, mas não para os casos de direitos coletivos em que ela pertença à coletividade tutelada. Nos Estados Unidos, de outro modo, a questão é inversa, questionando-se a legitimidade do sujeito nos casos em que a tutela é do interesse geral.

Naquele país a promoção da defesa do erário público por iniciativa de um indivíduo mediante a chamada false claim ou qui tam $^{97}$, regulada por legislação de 1863 com posteriores alterações ${ }^{98}$. O autor individual propõe aludida ação em nome próprio e como representante do Estado com base em um caso de fraude contra o patrimônio público de que tenha conhecimento, pleiteando de forma cumulada o pagamento de multa civil dentro de parâmetros fixados em lei bem assim o pagamento de indenização correspondente ao

\footnotetext{
96 Há quem entenda, contudo, que a legitimidade individual decorreria da própria Constituição por decorrência do disposto no artigo $5^{\circ}$, inciso XXXV, que assegura o acesso ao Judiciário para a tutela de um direito próprio violado. Como a tutela desse direito só se faria possível mediante ação coletiva, seria o titular individual legitimado a propô-la (FONSECA; LEITE, 2012, pp. 360/361).

${ }^{97}$ Forma abreviada de "qui tam pro domino rege quam pro se ipso in hac part sequitur" cuja tradução para a língua portuguesa equivaleria a "aquele que é para o rei, assim como é para si próprio" (COSTA, 2009, p. 97).

98 A chamada False Claim Act, também conhecida como Lincoln Law, Informer's Act ou Qui Tam Statute (COSTA, 2009, p. 97).
} 
triplo do dano causado ao erário. Funciona aludida ação como instrumento para trazer ao conhecimento do Estado certos casos de lesão ao patrimônio público, de modo a ensejar a sua reparação. Não se admite a propositura individual da false claim se já houver ação pendente com o mesmo objeto ou para casos que já fossem do conhecimento estatal, exceto se em decorrência de revelação do mesmo sujeito a figurar como autor.

Um dos principais questionamentos a respeito dessa ação se refere à legitimidade (standing) do autor individual ${ }^{99}$, eis que, em razão do ato não ter lesado o seu próprio patrimônio, a reparação do dano não lhe trará vantagens diretas e pessoais, beneficiando apenas o patrimônio público, entendido como um interesse geral. Normalmente, diante de interesses difusos e coletivos, a legitimação do sujeito isolado encontra fundamento no benefício direto por ele auferido com a tutela pleiteada. Mesmo nas class actions baseadas em questões coletivas, por exemplo, exige-se que o autor individual seja membro da classe de forma que os interesses que venha a defender lhe sejam próprios e diretos, do contrário, por não pertencer à classe, não será considerado seu representante adequado.

Um dos argumentos empregados para justificar a legitimidade dos autores individuais nesses casos diz respeito a uma peculiaridade das false claims, consistentes na sua capacidade de proporcionar uma recompensa para o autor no caso de procedência ${ }^{100}$, atribuindo a este um interesse direto e pessoal na demanda. Caso a ação seja proposta por um autor individual, prevê-se a possibilidade do Estado assumir a sua posição no polo passivo da demanda, passando o indivíduo a figurar como assistente, caso em que sua recompensa pode variar de quinze a vinte por cento do valor da causa. Se, de outro modo, deixar o Estado de intervir, a recompensa será de vinte e cinco a trinta por cento do valor da causa.

\footnotetext{
${ }^{99}$ Susana Henriques da Costa aponta outros dois questionamentos de índole constitucional formulados a respeito das false claims: a impossibilidade do indivíduo comum representar o Estado por não ser um funcionário público nomeado nos termos da Constituição, sendo indevido ao Congresso permitir por meio de lei a atuação do particular sem o consentimento do Executivo; e a violação do princípio da separação dos poderes, eis que retiraria do Executivo sua função de fazer valer a lei. Nenhum desses questionamentos prevaleceu, todavia, tendo a Suprema Corte reconhecido a constitucionalidade das false claims (COSTA, 2009 , pp. $104 / 110$.

${ }^{100}$ Também se protege o empregado de represálias do seu empregador em razão da propositura da ação ou de testemunho que tenha dado a esse respeito, prevendo a reintegração no cargo e o pagamento de verbas atrasadas em dobro e outros montantes indenizatórios (COSTA, 2009, p. 101).
} 
No direito processual brasileiro função similar é desempenhada pela ação popular proposta por cidadão para a tutela do patrimônio público pecuniário e da moralidade administrativa $^{101}$. Nesse caso o cidadão não auferirá nenhum benefício direto e pessoal da tutela que eventualmente venha a ser concedida, eis que os valores obtidos são destinados ao erário público, não se prevendo qualquer recompensa ou outra forma de incentivo. Isso, no entanto, não leva a questionamentos a respeito da legitimidade do cidadão para figurar no polo ativo do processo, decorrendo a mesma diretamente da Constituição (artigo $5^{\circ}$, inciso LXXIII) e da Lei da Ação Popular (artigo $1^{\circ}$ ), aplicando-se o instituto da substituição processual.

A propositura da ação popular no direito brasileiro está ligada ao exercício da cidadania daí porque a legitimidade pertencer ao cidadão -, partindo de uma visão do interesse metaindividual dissociada de interesses pessoais diretos e calcada na concepção de coletividade fundada em sentimentos de solidariedade. Nesse sentido, espera-se do individuo que atue com intuito meramente cívico, constituindo a ação popular um instrumento de democracia participativa ${ }^{102}$. O incentivo da recompensa não foi adotado pelo legislador e encontraria resistência em razão da suposta aplicação do princípio da indisponibilidade do interesse público, devendo se ressaltar, a esse respeito, o crescente entendimento de que o interesse pecuniário não configura necessariamente interesse público primário, de modo a se admitir certa disponibilidade na medida em que o dispêndio se faça para atender interesse público de maior relevância.

A prática da ação popular revelou, entretanto, que grande parte das medidas propostas traziam de fato um interesse subjacente do autor sem correspondência com o espírito cívico. Notou-se que razões políticas, sobretudo relacionadas ao processo eleitoral, motivavam o ajuizamento de muitas ações populares por correligionários de partidos opositores. Pretendia-se, nesses casos, que a repercussão do ajuizamento da demanda por conta da sua divulgação pela imprensa impactasse negativamente a campanha eleitoral dos adversários políticos dos sujeitos por trás da ação.

\footnotetext{
${ }^{101} \mathrm{O}$ cabimento de ações populares é muito mais amplo, abrangendo os bens e direitos de valor econômico, artístico, estético, histórico ou turístico que integram o patrimônio público, conforme artigo $1^{\circ}$, parágrafo ${ }^{\circ} 1$ da Lei n. 4.717/65, bem assim a moralidade administrativa, o meio ambiente e outras formas de expressão do patrimônio histórico e cultural nos termos do artigo 5º inciso LXXIII da Constituição de 1988.

${ }^{102}$ COSTA, 2009, p. 111.
} 
O simples fato de existirem interesses individuais a motivar o manejo da ação popular não é, por si só, negativo. Mesmo que inexista o propósito de angariar vantagem eleitoral pelo autor da demanda, é comum que algum interesse pessoal de outra índole seja o que o impulsione a ingressar em juízo. Esperar que o sujeito espontaneamente assuma a condição de demandante e arque com os custos (em sentido lato) do processo sem que tenha a expectativa de atender algum interesse pessoal é, no mínimo, uma ingenuidade. Esse é o entendimento de Susana Henriques da Costa:

Pensar, todavia, que o cidadão irá dispor-se a litigar contra terceiras pessoas e, eventualmente, contra o Poder Público, por motivos meramente altruístas é uma utopia. Na grande maioria dos casos, haverá um móvel individual por trás da sua conduta. Essa constatação, entretanto, não é negativa, muito menos serve de motivo para o descrédito da ação popular. Trata-se de uma forma legítima de, por meio de interesses individuais, tutelar-se o interesse público ${ }^{103}$.

A lei prevê mecanismos para prevenir que se faça o uso inadequado da ação popular de modo a prejudicar os interesses que devam constituir o seu objeto ou causar danos infundados para o réu. O indeferimento de petições iniciais descabidas, a aplicação das penas da litigância de má-fé em caso de lide temerária (artigo 13 da Lei da Ação Civil Pública), bem assim a possibilidade de outros sujeitos legitimados ou do Ministério Público assumirem o polo ativo da demanda em caso de desistência ou "absolvição de instância" causada pelo autor original (artigo $9^{\circ}$ da Lei da Ação Popular), e o reexame necessário da demanda pelo tribunal nos casos de improcedência ou extinção da ação sem resolução de mérito (artigo 19 da Lei da Ação Popular), são alguns de tais instrumentos.

Reconhecendo-se, assim, que mesmo nos casos de ação popular tem o autor individual um interesse próprio na propositura da demanda, prevendo-se mecanismos para a apuração da representatividade adequada, em conjunto com instrumentos de controle de atuação do legitimado individual, deveria ser reconhecida sua legitimidade para a defesa de interesse coletivo pertencente à coletividade da qual faz parte.

${ }^{103}$ COSTA, 2009, p. 112. 
Conforme apontado, assegura-se ao indivíduo que entenda ser titular de um direito violado ou sob ameaça de violação, a possibilidade de submeter seu pedido de tutela ao Poder Judiciário. Essa proximidade entre o autor da ação e o conflito material objeto do processo pode se mostrar positiva para a defesa da pretensão ajuizada, havendo comprometimento do autor em buscar o resultado da demanda que lhe favoreça no mundo da vida ${ }^{104}$. Ademais, não se pode descartar a possibilidade dos entes legitimados, com pertinência temática para a matéria, não estarem, por diversos motivos, disponíveis para propor a demanda $^{105}$.

\subsection{O CÓDIGO DE PROCESSO CIVIL PROJETADO}

Por fim, há de se observar que se encontra em discussão no Congresso Nacional um novo Código de Processo Civil, no qual se prevê expressamente o mecanismo de conversão de ação individual em coletiva. Nos termos em que atualmente se encontra redigido, o fenômeno se dará por requerimento de um dos entes legitimados a propor ação civil pública nos casos de ação individual cujo objeto verse sobre a tutela de bem difuso ou coletivo, afetando as esferas jurídicas do indivíduo e da coletividade, ou outros casos de relação jurídica plurilateral em que a solução afetará de forma uniforme todos os membros

\footnotetext{
104 "Os processos judiciais iniciados por partes privadas podem servir a seus propósitos particulares. Imaginese um acordo de fixação de preços entre corretores de valores mobiliários e um processo judicial proposto por um dos investidores pleiteando uma injunction para prevenir a fixação de preços no futuro ou para recuperar os prejuízos resultantes do dano que lhe foi imposto. O processo pode destinar-se ao pleito ou à proteção dos direitos individuais do investidor. Entretanto, um propósito público também pode ser alcançado por este mesmo processo no sentido de que, se bem-sucedido, fará com que o comportamento dos corretores adapte-se à lei antitruste. Uma injunction contra a fixação de preços no futuro, claramente, teria esse efeito, mas também o teria uma indenização ao investidor pelos danos sofridos. Essa indenização forçaria os corretores a absorver os custos de sua má conduta e, considerando princípios comuns de prevenção de ilícitos, desencorajaria violações futuras pelos réus e outros corretores." (FISS, Owen. Um novo processo civil: estudos norte-americanos sobre jurisdição, constituição e sociedade. Tradução de Daniel Porto Godinho da Silva e Melina de Medeiros Rós. Coordenação de tradução de Carlos Alberto de Salles. São Paulo: RT, 2004, p. 234).

105 "Não se pode esquecer de um fato importante bem lembrado por Carlos Alberto Bittar Filho: as associações e o Ministério Público não estão presentes em todos os locais. Nesses casos, quando a presença do promotor ou das associações não se faz sentir, retirar da pessoa física a possibilidade de propor uma demanda coletiva significará a ausência de prestação jurisdicional em sede de direitos supra-individuais" (FERRARESI, Eurico. A pessoa física como legitimada ativa à ação coletiva. In: GRINOVER, Ada Pellegrini; MENDES, Aluisio Gonçalves de Castro; WATANABE, Kazuo (Coord.). Direito processual coletivo e o anteprojeto de código brasileiro de processos coletivos. São Paulo: RT, 2007, p. 137). O autor ressalta, ainda, que a legitimidade do Ministério Público acabou por servir como razão para que a sociedade civil permanecesse inerte, de forma que a grande maioria das ações coletivas seja proposta pelo MP, em muitos casos as associações se limitando a representar ao órgão para cobrar a sua atuação.
} 
do grupo, excluindo-se expressamente as hipóteses envolvendo apenas direitos individuais homogêneos. ${ }^{106}$

${ }^{106}$ CAPÍTULO IV

DA CONVERSÃO DA AÇÃO INDIVIDUAL EM AÇÃO COLETIVA

Art. 334. Atendidos os pressupostos da relevância social e da dificuldade de formação do litisconsórcio, o juiz, a requerimento do Ministério Público ou da Defensoria Pública, ouvido o autor, poderá converter em coletiva a ação individual que veicule pedido que:

I - tenha alcance coletivo, em razão da tutela de bem jurídico difuso ou coletivo, assim entendidos aqueles definidos pelo art. 81, parágrafo único, incisos I e II, da Lei $\mathrm{n}^{\circ}$ 8.078, de 11 de setembro de 1990, e cuja ofensa afete, a um só tempo, as esferas jurídicas do indivíduo e da coletividade;

II - tenha por objetivo a solução de conflito de interesse relativo a uma mesma relação jurídica plurilateral, cuja solução, pela sua natureza ou por disposição de lei, deva ser necessariamente uniforme, assegurando-se tratamento isonômico para todos os membros do grupo.

$\S 1^{\circ} \mathrm{O}$ requerimento de conversão poderá ser formulado por outro legitimado a que se referem os arts. $5^{\circ} \mathrm{da}$ Lei 7.347, de 24 de julho de 1985, e 82 da Lei no 8.078, de 11 de setembro de 1990.

$\S 2^{\circ}$ A conversão não pode implicar a formação de processo coletivo para a tutela de direitos individuais homogêneos.

$\S 3^{\circ}$ Não se admite a conversão, ainda, se:

I - já iniciada, no processo individual, a audiência de instrução e julgamento; ou

II - houver processo coletivo pendente com o mesmo objeto; ou

III - o juízo não tiver competência para o processo coletivo que seria formado.

$\S 4^{\circ}$ Determinada a conversão, o juiz intimará o autor do requerimento para que, no prazo fixado, adite ou emende a petição inicial, para adaptá-la à tutela coletiva.

$\S 5^{\circ}$ Havendo aditamento ou emenda da petição inicial, o juiz determinará a intimação do réu para, querendo, manifestar-se no prazo de quinze dias.

$\S 6^{\circ} \mathrm{O}$ autor originário da ação individual atuará na condição de litisconsorte unitário do legitimado para condução do processo coletivo.

$\S 7^{\circ} \mathrm{O}$ autor originário não é responsável por qualquer despesa processual decorrente da conversão do processo individual em coletivo.

$\S 8^{\circ}$ Após a conversão, observar-se-ão as regras do processo coletivo.

$\S 9^{\circ}$ A conversão poderá ocorrer mesmo que o autor tenha cumulado pedido de natureza estritamente individual, hipótese em que o processamento desse pedido dar-se-á em autos apartados.

$\S 10$. O Ministério Público deverá ser ouvido sobre o requerimento previsto no caput, salvo quando ele próprio o houver formulado. 


\section{CONCLUSÃO}

O interesse representa uma relação de complementaridade entre o homem e um bem, baseada na necessidade daquele e na utilidade deste. Nesse sentido, o interesse expressa uma demanda de um sujeito por um bem.

Encontrando-se no mesmo plano, os interesses relacionam-se entre si de forma constante, fenômeno este observado não só na esfera social, como também na natural, envolvendo outros seres vivos. Essas relações podem caracterizar conflito, de modo que o atendimento de um interesse seja incompatível com o de outro, ou um vínculo de solidariedade, caso a satisfação de uma necessidade contribua para a satisfação de outra.

As relações de solidariedade estabelecem a base para a formação dos interesses coletivos, entendidos como, sob o aspecto objetivo, aqueles que recaem sobre um mesmo bem coletivo, capaz de atender de forma unitária e inevitável necessidades semelhantes de uma pluralidade de sujeitos, ou, sob o aspecto subjetivo, a busca ao atendimento conjunto de necessidades semelhantes de diversos indivíduos, baseada em um sentimento de solidariedade que amalgama os interesses como se constituíssem uma unidade.

Nesse contexto, o Direito serve como instrumento para dois fins: (i) regular e organizar esforços e recursos para o atendimento de interesses coletivos relevantes, os quais, por vezes, podem se referir à satisfação de necessidades individuais tidas como de elevado valor; e (ii) oferecer critérios para a resolução de conflitos intersubjetivos, evitando o uso da força ou a perpetuação dos conflitos capazes de criar um estado de desagregação social.

Serve o Direito ao propósito de resolver conflitos, em primeiro lugar, pelo reconhecimento de certos interesses como interesses jurídicos. Tradicionalmente, a principal categoria de interesses protegidos é abarcada no conceito de direito subjetivo, pautada na liberdade e autonomia individuais, dando ao seu titular ou a terceiro que o represente, conforme a sua vontade, certo poder de fazer prevalecer o seu interesse sobre outrem. Outros interesses individuais recebem proteção mais atenuada do ordenamento jurídico, sendo conhecidos 
como interesses simples e interesses legítimos, ficando dependentes ou submetidos a outros interesses, notadamente ao interesse público.

Ao lado dos esforços espontâneos individuais para o atendimento de interesses comuns dentro da esfera privada, inclusive por meio da criação de grupamentos organizados tais como sociedades e associações, a principal forma de consagração de interesses coletivos se dá por meio do conceito de interesse público. Apesar de não ser considerado interesse de titularidade do Estado, e sim da coletividade, é o atendimento do interesse público o que pauta, legitima e limita a atuação estatal. Diante da sua importância e titularidade disseminada, é indisponível e goza de certa precedência sobre interesses individuais, nos termos fixados pela Constituição e pela legislação que a complementa.

A definição de um interesse como público apresenta dupla relevância, pois autoriza a sua perseguição pelo Estado e o coloca numa posição de superioridade com relação a interesses meramente individuais, exceto com relação àqueles incorporados em direitos fundamentais. O papel de definição do conteúdo do interesse público sempre coube precipuamente ao legislador, e, de forma subsidiária, à Administração Pública, tendo por parâmetro as noções de bem comum e interesse geral. Com a assunção pelo Poder Público de inúmeras novas funções relacionadas ao Estado Social, e o correspondente reconhecimento de direitos fundamentais de segunda e terceira dimensões de caráter social e de solidariedade, sob a influência de grupos de interesse que se formavam em torno dos interesses coletivos encampados nesses direitos, deixou o interesse público de ser uno e homogêneo, passando a ser plúrimo e heterogêneo, incorporando esses interesses no seu objeto.

Em virtude dessa mudança, a tarefa de definição dos interesses públicos nos casos concretos e a determinação de qual o prevalecente em situações de conflito, inclusive no que toca à alocação de recursos e bens coletivos escassos, assumiu maior complexidade. Sem abandonar os valores e princípios fundamentais da sociedade, a escolha legítima se faz por meio da construção de um processo decisório preconcebido, em que se admita a participação dos grupos de interesse pertinentes. Se o consenso a respeito da escolha jamais existirá, ao menos poderá recair sobre o processo decisório, o que se faria suficiente para conferir legitimidade à escolha. De qualquer forma, tratando-se de embate entre interesses de igual estatura e relevância, o método de resolução do conflito deve se pautar 
pelo princípio da proporcionalidade, de forma a que os sacrifícios sejam mínimos e possam se aproveitar ao máximo todos os interesses contrapostos.

Assim, em paralelo ao interesse público sob o domínio do Estado, reconheceram-se juridicamente outras categorias de interesses metaindividuais, marcados pela indivisibilidade do objeto e a pluralidade de titulares. Os difusos, decorrentes de uma relação de fato, e marcados pela sua fluidez, pertencendo a titulares indeterminados e indetermináveis. Os coletivos em sentido estrito, estabelecidos em uma coletividade formada em torno de um vínculo jurídico que liga os seus membros, seja ele uma relação jurídica entre tais membros ou com a parte adversa. Aludidos interesses, muito embora não se confundam com a ideia de interesse geral, são reconhecidos como espécies de interesse público, o que fica evidente ao se constatar que o seu atendimento se tornou objetivo da atuação do Poder Público.

Todas essas espécies de interesses metaindividuais encontram substrato no atendimento de necessidades individuais, eis que os seres humanos são o único ente capaz de experimentálas, fazendo-o individualmente. Os portadores dessas necessidades, no caso dos interesses coletivos em sentido estrito, são os membros da coletividade em questão. O mesmo se aplica no tocante aos interesses difusos, por mais que aqui seja impossível identificar quem são esses sujeitos: as necessidades são presumidas com base na utilidade do bem a que se refere o interesse, bem assim no conhecimento acumulado a respeito do ser humano e de suas necessidades. Considerando o interesse geral, sob o entendimento de que não se confunde com os difusos e coletivos, tal relação fica menos evidente, mas não deixa de existir. Nesse caso, as necessidades individuais podem ser imateriais ou receber atendimento indireto, dotando-se o interesse geral de caráter instrumental.

Concebendo-se uma demanda como a busca pela satisfação de uma necessidade, a proteção jurídica de interesses coletivos, nas noções de interesse público, interesse difuso e interesse coletivo representa uma forma de coletivização de demandas individuais no plano material, legitimando sua perseguição pelo Estado.

Serve o Direito como um mecanismo de ordenação da sociedade, fornecendo critérios para a coordenação de interesses, bem assim para a resolução dos conflitos que rotineiramente 
se estabelecem, desencorajando o uso da violência e promovendo a paz social, representando a solução pacífica de conflitos, um interesse coletivo público.

As normas de direito material não são por si só capazes, contudo, de eliminar os conflitos, sobretudo em razão da pretensão de uma parte, fundada ou não no direito, por vezes encontrar a resistência da outra, com ou sem suporte no direito, sem que uma ceda à posição da outra, nada obstante o critério normativo posto favoreça uma delas. Assim, reservando-se o monopólio da força, fornece o Estado um mecanismo de solução de controvérsias - o processo - para a justa composição da lide (Carnelutti) por meio da atuação da vontade concreta do direito material (Chiovenda).

O processo tradicionalmente manteve proximidade com o direito material. No período sincrético, o processo pertencia ao direito privado, correspondendo a um mero modo de exercício do direito subjetivo. Com a fase autonomista, desvencilhou-se o direito processual do direito privado, desenvolvendo o seu arcabouço institucional e principiológico próprio, tornando-se um ramo autônomo do direito. No atual período instrumentista, sobrelevou-se o aspecto teleológico do processo, passando a ser examinado e estruturado como um instrumento para o atendimento de certas finalidades a ele externas, legitimando-se pela sua efetividade em proporcioná-las.

Além do escopo jurídico alusivo à efetivação do direito material, concebem-se escopos políticos e sociais ao processo, destacando-se dentre eles a promoção da paz social com justiça. Nesse movimento, desenvolveu-se o princípio do acesso à justiça, propugnando pela identificação e eliminação dos óbices ao acesso à ordem jurídica justa, inclusive no que toca aos custos do processo e à criação de mecanismos viabilizadores do ingresso no sistema processual de conflitos que ficavam à sua margem, criando uma litigiosidade contida.

Nessa evolução, o processo que tradicionalmente era voltado para o tratamento de conflitos individuais rodeando o universo do direito subjetivo, e que dessa forma excluía conflitos envolvendo interesses metaindividuais, recebeu novo instrumental para dar tratamento para interesses coletivos, com titularidade indeterminada ou indeterminável, que se tornaram interesses jurídicos ou verdadeiros direitos. Desenvolveram-se, assim, as ações coletivas, permitindo o processo sem a participação direta de todos os membros da coletividade, mas 
dele advindo uma tutela capaz de beneficiar a todos, sobretudo em razão da indivisibilidade de seu objeto.

Surgiu, assim, um processo civil de interesse público, habilitando o Poder Judiciário a decidir a respeito do interesse público representado pelos novos interesses tutelados, indicando aqueles preponderantes e dando destinação a bens e recursos coletivos, de modo a realizar justiça distributiva. Superaram-se as críticas dirigidas à essa nova atribuição do Poder Judiciário, sobretudo por atuar em razão da incapacidade dos demais Poderes em amparar os interesses coletivos, representando o processo judicial também um mecanismo de democracia participativa, menos suscetível às pressões sofridas pelos Poderes majoritários.

Além de um processo adequado ao tratamento de interesses coletivos, com inspiração nas class actions norte-americanas, aprimorou-se o mecanismo para constituir um instrumento de tratamento coletivizado de interesses individuais que, em razão de sua origem comum, guardassem suficiente homogeneidade. Esse tratamento coletivizado se revela possível em razão da prevalência dos elementos comuns sobre os individuais, tornando interesses materialmente individuais em acidentalmente coletivos. Esse emprego das ações coletivas viabilizou a tutela de direitos de pequena expressão econômica, na sua dimensão individual, que de outra forma não motivariam o ajuizamento de uma demanda em razão do pequeno proveito que poderiam proporcionar ao seu titular, considerando os custos a serem incorridos com o processo.

Outros efeitos positivos da tutela coletiva dos interesses individuais homogêneos constituíram a inibição de práticas lesivas por agentes econômicos, a promoção da economia processual e a redução de processos repetitivos, mitigando-se o risco do conflito lógico de julgados a respeito de casos semelhantes.

No Brasil, assim, desenvolve-se um conceito de processos coletivos em torno da natureza dos direitos por ele tutelados: difusos, coletivos em sentido estrito e individuais homogêneos, bem assim em função da sua defesa se dar por um representante da coletividade, por meio da técnica da substituição processual. Nos Estados Unidos, de outro modo, por mais que as class actions ocupem posição central para os estudiosos do direito, os mecanismos de coletivização são considerados de forma mais abrangente, albergando, 
inclusive, técnicas de gerenciamento conjunto de processos (coordenation e consolidation), e mecanismos privados de agregação entre as partes.

Considerando a diferenciação de diversos princípios e institutos processuais empregados nos processos coletivos, há quem sustente ter-se formado um novo ramo do direito processual: o Direito Processual Coletivo, por mais que não se reconheça uma relação de interdependência entre os diplomas normativos alusivos a cada espécie de mecanismo. Aludida posição tem o mérito de fortalecer o processo coletivo, fornecendo argumentos para a promulgação de um diploma normativo que aprimore e compatibilize os seus institutos. Por outro lado, incentiva uma ruptura com o processo civil tradicional, que hoje não pode mais ficar à revelia do fenômeno coletivo, sobretudo porque os interesses coletivos apresentam uma dimensão pessoal.

A noção de interesse processual se desvencilha do interesse material, mas também apresenta os componentes da necessidade e da utilidade (ou adequação). Há interesse processual se o bem da vida pleiteado não puder ser obtido espontaneamente e despontará a utilidade se a tutela pleiteada for capaz de proporcioná-lo. No que toca aos processos coletivos, deixa o interesse processual de se vincular com o titular do interesse material subjacente, passando a se apoiar na relevância do objeto tutelado. Como a parte formal da demanda não é a titular do direito material, o critério para aferição do seu interesse processual recai na pertinência temática.

A respeito da legitimidade de agir, nota-se que para as ações coletivas se faz indispensável a técnica da substituição processual ou legitimidade extraordinária, uma vez que se revela inviável, ou até mesmo impossível, a presença de todos os membros da coletividade no processo. Não se previu a legitimidade da pessoa natural para a propositura de ação coletiva, com exceção do cidadão para a ação popular. Todos os legitimados agem para a tutela de direito que não lhe pertence. $O$ fato de perseguirem suas atribuições não os torna titulares do direito, conferindo-lhes apenas pertinência temática para aturarem em juízo. Além de encontrar-se inscrita no rol dos legitimados, para que possa propor ação coletiva deve a entidade ser representante adequado da coletividade, o que pode ser apurado pelo juiz, com espaço de discricionariedade reduzido. 
Demandas coletivas, assim como as individuais, também estabelecem relações entre si. Havendo conexão pela sobreposição parcial dos elementos das demandas, impõe-se a sua reunião para processamento e julgamento conjunto, desde que respeitadas certas regras, como a da competência, bem assim que dessa reunião no caso concreto possa resultar o convencimento unificado no juiz, com ganhos de economia processual e consistência de julgados.

Os efeitos da litispendência e da coisa julgada se produzem entre ações coletivas desde que reproduzidos os três elementos (partes, causa de pedir e pedido), considerando a coletividade substituída. Prevê-se que a litispendência de ação coletiva não prejudica as demandas individuais. A coisa julgada material produzida em demanda coletiva beneficia toda a coletividade, podendo ser transportada para o domínio dos processos envolvendo questões individuais. Eventual sentença de improcedência não impede a propositura de demanda individual, mas prejudica nova demanda coletiva, exceto se a sucumbênia for decorrente de insuficiência probatória.

Nada obstante a existência do sistema de tutelas coletivas, despontam na atualidade casos de processos repetitivos, agravando o problema do congestionamento dos tribunais e afetando o provimento de justiça com qualidade e celeridade. Os focos para a identificação do problema se colocam no plano legislativo, em razão das restrições e limitações impostas às demandas coletivas; no plano estrutural, em função da falta de recursos materiais e humanos, bem assim por deficiências administrativas do Poder Judiciário; e no plano cultural, prevalecendo a cultura individualista e da sentença.

A multiplicação de demandas coletivas ocasiona morosidade, levando a práticas de massificação do tratamento de litígios com prejuízo ao contraditório. O tratamento individual dessas demandas, por outro lado, é terreno fértil para decisões contraditórias. Também o Poder Judiciário, enquanto aparato estatal, e os juízes, enquanto indivíduos, sofrendo com o acúmulo de trabalho, tendem a privilegiar a quantidade à qualidade, denegando justiça em beneficio de uma celeridade morosa.

Em atendimento aos ditames da efetividade, inclusive no que toca à tempestividade da tutela, devem ser cogitadas medidas para tornar o processo capaz de lidar com os litígios em tempo razoável, distribuindo justiça em conformidade com o direito material. 
Potenciais caminhos passam por aprimoramentos na estrutura do Poder Judiciário, o desenvolvimento da cultura de soluções coletivizadas entre os operadores do direito, bem assim da cultura da pacificação em substituição à cultura da sentença, de modo a se privilegiar a adoção de mecanismos alternativos de solução de controvérsias também de índole coletiva, a exemplo dos fundos de indenização criados nos Estados Unidos.

No campo especificamente processual, nota-se uma tendência de valorização da jurisprudência e de técnicas de agregação em busca da resolução dos processos e recursos repetitivos, com o inconveniente de que tais técnicas se aplicam, no mais das vezes, somente depois de ajuizadas múltiplas demandas.

Nota-se, ademais, que casos de processos individuais repetitivos por vezes mascaram demandas pseudo-individuais, vez que fundadas em relação jurídica substancial coletiva e incindível, de modo que a decisão de um caso deva produzir efeitos para os demais sujeitos, sob pena da potencialidade do conflito prático entre julgados.

Considerando-se essas hipóteses, sustenta-se que se realize o gerenciamento dos processos pendentes, suspendendo-se os individuais para julgamento dos coletivos. Inviabilizada essa via, aventa-se a possibilidade de criação de mecanismo de conversão da demanda proposta de forma individual em demanda coletiva. Para tanto, haveria de se admitir o ingresso de um dos legitimados para tal ação no polo ativo da demanda, ou a previsão da legitimação do autor individual, desde que respeitado o requisito de representatividade adequada.

Daí se conclui pela constatação de diferentes níveis de coletivização no direito brasileiro. No primeiro plano, pelo reconhecimento dos interesses coletivos pelo direito material. No segundo plano pela criação das ações coletivas para dar-lhes tutela jurisdicional. No terceiro plano pelo tratamento coletivizado de interesses individuais homogêneos por meio da propositura de demanda coletiva. Por fim, por meio da possibilidade de conversão de uma demanda individual em coletiva.

Em uma sociedade de massa, pelo princípio da efetividade, deve o Direito ser capaz de se adaptar e dar uma resposta de massa para as questões dessa natureza, permitindo que todas 
as demais possam receber tratamento individualizado, criando efetivas condições para pacificação social com justiça. 


\section{BIBLIOGRAFIA}

ALESSI, Renato. Instituciones de Derecho Administrativo. Tradução de Buenaventura Pellisé Prats, Tomo I, Barcelona: Bosch, 1970.

ALEXY, Robert. Teoria dos Direitos Fundamentais. 2. ed. Tradução de Virgílio Afonso da Silva. São Paulo: Malheiros, 2011.

ALVIM, José Eduardo Carreira. Teoria Geral do Processo. 15. ed. Rio de Janeiro: Forense, 2012.

AMARAL JUNIOR, Alberto do. Lições de Direito. Barueri: Manole, 2011.

THE AMERICAN LAW INSTITUTE. Principles of The Law of Aggregate Litigation.St. Paul: American Law Institute Publishers, 2010.

ANDREWS, Neil. O Moderno processo civil: formas judiciais e alternativas de resolução de conflitos na Inglaterra. Orientação e revisão da tradução por Teresa Arruda Alvim Wambier. São Paulo: RT, 2010.

ARAÚJO CINTRA, Antonio Carlos de; GRINOVER, Ada Pellegrini; DINAMARCO, Cândido Rangel. Teoria Geral do Processo. 25. ed. São Paulo: Malheiros, 2009.

ARENHART, Sérgio Cruz. A Tutela Coletiva de Interesses Individuais: para além da proteção dos interesses individuais homogêneos. São Paulo: RT, 2013.

BANDEIRA DE MELLO, Celso Antônio. Curso de Direito Administrativo. 28. ed., São Paulo: Malheiros, 2011.

BANDEIRA DE MELLO, Oswaldo Aranha. Princípios Gerais de Direito Administrativo. vol. I. 2. ed., Rio de Janeiro: Forense, 1979. 
BAPTISTA DA SILVA, Ovídio A. Curso de Processo Civil. vol.1: processo de conhecimento. 4. ed. São Paulo: RT, 1998.

BARbosa MOREIRA, José Carlos. A Ação Popular do Direito Brasileiro como Instrumento de Tutela Jurisdicional dos Chamados "Interesses Difusos". In: Temas de Direito Processual: primeira série. 2. ed. Saraiva: São Paulo, 1988.

La iniciativa en la defensa judicial de los intereses difusos y colectivos: (un aspecto de la experiencia brasileña). In: Temas de Direito Processual: Quinta série. São Paulo: Saraiva, 1994, pp. 165/166.

Notas sobre o Problema da "Efetividade do

Processo". In: Temas de Direito Processual: terceira série. 1. ed. Saraiva: São Paulo, 1984. pp 27/42.

Tutela Jurisdicional dos Interesses Coletivos

ou Difusos. In: Temas de Direito Processual: terceira série. 1. ed. Saraiva: São Paulo, 1984. pp 193/221.

A Legitimação para a Defesa dos "Interesses

Difusos" no Direito Brasileiro. In: Temas de Direito Processual: terceira série. 1. ed. Saraiva: São Paulo, 1984. pp 183/192

CAPPELlETTI, Mauro; GARTH, Bryant. Acesso à justiça. Tradução de Ellen Gracie Northfleet. Porto Alegre: Sergio Fabris, 1988.

BEDAQUE, José Roberto dos Santos. Tutela Cautelar e Tutela Antecipada: Tutelas Sumárias e de Urgência (tentativa de sistematização). 5. ed. São Paulo: Malheiros, 2009.

BEVILACQUA, Clóvis. Theoria Geral do Direito Civil. Campinas: RED, 1999.

CARNELUTTI, Francesco. Sistema de Direito Processual Civil. vol. I. Tradução de Hiltomar Martins Oliveira. São Paulo: Classic Book, 2000. 
Teoria Geral do Direito. Tradução de Antônio

Carlos Ferreira. São Paulo: Lejus, 2006.

CHIOVENDA, Giuseppe. Instituições de Direito Processual Civil. Tradução de Paolo Capitanio. Vol. I. 1. ed. Campinas: Bookseller, 1998.

COSTA, Susana Henriques da. Condições da Ação. São Paulo: Quartier Latin, 2005.

O Processo coletivo na Tutela do Patrimônio

Público e da Moralidade Administrativa: ação de improbidade administrativa, ação civil pública e ação popular. São Paulo: Quartier Latin, 2009.

CRETElla JÚNIOR, José. Tratado de Direito Administrativo: teoria do direito administrativo, vol. I, 2. ed. Rio de Janeiro: Forense, 2002.

DEL VECCHIO, Giorgio. Lições de Filosofia do Direito. Tradução de António José Brandão. 5. ed. Coimbra: Arménio Amado, 1979.

DERANI, Cristiane. Privatização e Serviço Público: as ações do Estado na produção econômica. São Paulo: Max Limonad, 2002

DI PIETRO, Maria Sylvia Zanella. O princípio da supremacia do interesse público: sobrevivência diante dos ideais do neoliberalismo. In: Revista Trimestral de Direito Público, São Paulo, n. 48, 2004, p. 63- 76.

Discricionariedade Administrativa na

Constituição de 1988. 2. ed. São Paulo: Atlas, 2007

DIDIER JUNIOR, Fredie. Litisconsórcio necessário ativo(?). In: MOREIRA, Alberto Camiña; ALVAREZ, Anselmo Prieto; BRUSCHI, Gilberto Gomes (Coord.). Panorama atual das tutelas individual e coletiva: estudos em homenagem ao professor Sérgio Shimura. São Paulo: Saraiva, 2011, p. 401-410. 
DINAMARCO, Cândido Rangel. A Instrumentalidade do Processo. 9. ed. Malheiros: São Paulo, 2001.

Instituições de Direito Processual Civil. Vol.

II. São Paulo: Malheiros, 2001.

Instituições de Direito Processual Civil. Vol. I.

5. ed. São Paulo: Malheiros, 2005.

Litisconsórcio. 8. ed., ver. e atual., São Paulo:

Malheiros, 2009.

\section{Fundamentos do Processo Civil Moderno.}

Tomo I. $6^{\text {a }}$ ed. São Paulo, Malheiros, 2010.

FELSBERG, Keneth. Democratization of Mass Litigation: Empowering the Beneficiaries. In: Columbia Journal do Law and Social Problems, vol. 45, 2012, pp. 481498.

FERRARESI, Eurico. A pessoa física como legitimada ativa à ação coletiva. In: GRINOVER, Ada Pellegrini; MENDES, Aluisio Gonçalves de Castro; WATANABE, Kazuo (Coord.). Direito processual coletivo e o anteprojeto de código brasileiro de processos coletivos. São Paulo: RT, 2007, p. 136-1143.

FERRAZ JUNIOR, Tercio Sampaio. Introdução ao Estudo do Direito: Técnica, decisão, dominação. 2. ed. São Paulo: Atlas, 1994.

Interesse Público. Disponível em http://www.terciosampaioferrazjr.com.br/?q=/publicacoes-cientificas/31. Acessado em 31 de outubro de 2013.

FISS, Owen. Um novo processo civil: estudos norte-americanos sobre jurisdição, constituição e sociedade. Tradução de Daniel Porto Godinho da Silva e Melina de Medeiros Rós. Coordenação de tradução de Carlos Alberto de Salles. São Paulo: RT, 2004. 
FONSECA, Bruno Bomes Borges da; LEITE, Carlos Henrique Bezerra. Acesso à Justiça e Ações Pseudoindivduais: (I)legitimidade Ativa do Indivíduo nas Ações Coletivas. Revista de Processo, vol. 203, ano 37, janeiro 2012, pp. 347/365.

GIDI, Antonio. Coisa Julgada e Litispendência em Ações Coletivas. São Paulo: Saraiva, 1995.

A class action como instrumento de tutela coletiva dos direitos: as ações coletivas em uma perspectiva comparada. São Paulo: Revista dos Tribunais, 2007.

GRINOVER, Ada Pellegrini. A Tutela Jurisdicional dos interesses difusos. In: Revista de Processo, N. 14/15, ano 6, 1979, pp. 25/45.

Ação Civil Pública Refém do Autoritarismo.

In: O processo: estudos e pareceres. 2. ed. rev. e ampl. São Paulo: DPJ Editora, 2009, pp. 290/301.

In: GRINOVER, Ada Pellegrini; NERY JUNIOR, Nelson; WATANABE, Kazuo. Código Brasileiro de Defesa do Consumidor: comentado pelos autores do anteprojeto. Vol. II: Processo Coletivo (arts. 81 a 104 e 109 a 119). 10. ed. Rio de Janeiro: Forense, 2011.

Os Fundamentos da Justiça Conciliativa. In: GRINOVER, Ada Pellegrini; LAGRASTA NETO, Caetano; WATANABE, Kazuo (coord.). Mediação e Gerenciamento do Processo: revolução na prestação jurisdicional. São Paulo: Atlas, 2013.

JHERING, Rudolf Von. A Luta Pelo Direito. Tradução e apresentação de Richard Paul Neto. Rio de Janeiro: Rio, 1978.

JUSTEN FILHO, Marçal. Conceito de Interesse Público e a Personalização do Direito Administrativo. In: Revista Trimestral de Direito Público, 26/1999, pp. 115/136. 
KELSEN, Hans. Teoria Pura do Direito. Tradução de João Baptista Machado. São Paulo: Martins Fontes, 1995.

LEONEL, Ricardo de Barros. Manual do Processo Coletivo. 2. ed. São Paulo: RT, 2011.

LIEBMAN, Enrico Tullio. Manual de Direito Processual Civil. Vol. I. Tradução e notas de Cândido Rangel Dinamarco. $3^{\text {a }}$ ed. São Paulo: Malheiros, 2005.

LISBOA, Roberto Senise. Contratos Difusos e Coletivos: consumidor, meio ambiente, trabalho, agrário, locação, autor. São Paulo: RT, 1997,

MANCUSO, Rodolfo de Camargo. Interesses Difusos: Conceito e Colocação no Quadro Geral dos Interesses. In: Revista de Processo $n^{\circ}$ 55, ano 14, julho-setembro de 1989, p.167/168.

Interesses Difusos: conceito e legitimação para agir. 6. ed. São Paulo: Revista dos Tribunais, 2004.

MAZZILLI, Hugo Nigro. A Defesa dos Interesses Difusos em Juízo: meio ambiente, consumidor, patrimônio cultural, patrimônio público e outros interesses. 20. ed.rev. ampl. e atual. São Paulo: Saraiva, 2007.

MARINONI, Luiz Guilherme. Precedentes Obrigatórios. 2. ed. rev. e atual. São Paulo: Editora Revista dos Tribunais, 2011.

MARINS, Victor A. A. Bomfim. Comentários ao Código e Processo Civil, vol. 12: do processo cautelar, arts. 813 a 889. São Paulo: RT, 2000.

MARQUES NETO, Floriano Peixoto de Azevedo. Regulação Estatal e Interesses Públicos. São Paulo: Malheiros, 2002.

MEDAUAR, Odete. Direito Administrativo Moderno: de acordo com a EC 19/98. 4. ed., rev., atual. e ampl. São Paulo: Revista dos Tribunais, 2000. 
MENDES, Aluisio Gonçalves de Castro. O Direito Processual Coletivo, a legitimidade para agir nas ações coletivas e o Anteprojeto de Código Brasileiro de Processos Coletivos. In: SALLES, Carlos Alberto de (coord). As Grandes Transformações do Processo Civil Brasileiro Homenagem ao Professor Kazuo Watanabe. São Paulo: Quartier Latin, 2009.

Ações Coletivas no Direito Comparado e

Nacional. 2. ed. rev. atual. e ampl. São Paulo: Revista dos Tribunais, 2010.

MOREIRA ALVES, José Carlos. Direito Subjetivo, Pretensão e Ação. Revista de Processo n. 47, ano 12, julho/setembro 1987, pp. 109, 109/123.

MOREIRA NETO, Diogo de Figueiredo. Curso de Direito Administrativo: parte introdutória, parte geral e parte especial. 15. ed., revista, refundida e atualizada. Rio de Janeiro: Forense, 2009.

NALINI, José Renato. Direito Subjetivo, Interesse Simples, Interesse Legítimo. Revista de Processo, n 38, ano 10, abril-junho de 1985, pp. 240/250.

Ética e Justiça. São Paulo: Oliveira Mendes,

1998.

NUSDEO, Fábio. Curso de Economia: introdução ao Direito Econômico. 1. ed. São Paulo: Revista dos Tribunais, 1997.

ODUM Eugene P. Fundamentos de Ecologia. 6. ed. Lisboa: Fundação Calouste Gulbenkian, 2004.

PEREIRA, Caio Mário da Silva. Instituições de Direito Civil. vol. I, Atualizado por Maria Celina Bodin de Moraes. 20. ed. Rio de Janeiro: Forense, 2004.

RÁO, Vicente. O Direito e a Vida dos Direitos. 5. ed. anotada e atualizada por Ovídio Rocha Barros Sandoval. São Paulo: Revista dos Tribunais, 1999. 
REALE, Miguel. Lições Preliminares de Direito. 24. ed., São Paulo: Saraiva, 1998.

RICKLEFS, Robert E. A Economia da Natureza. 6 ed. Rio de Janeiro: Guanabara Koogan, 2010.

RISKIN, Leonard L. et al. Dispute Resolution and Lawyers. 4 ed. St. Paul: West Publishing, 2009.

ROSS, Alf. Direito e Justiça. Tradução e notas de Edson Bini. 1.ed. Bauru: Edipro, 2003.

SALlES, Carlos Alberto de. Execução Judicial em Matéria Ambiental. São Paulo: Revista dos Tribunais, 1999.

Processo Civil de interesse público: uma nova perspectiva metodológica. In: SUNDFELD, Carlos Ari; BUENO, Cassio Scarpinella (Coord.). Direito Processual Público: a Fazenda Pública em Juízo. São Paulo: Malheiros, 2000, pp. $45 / 65$.

Processo Civil de interesse público. In: SALlES, Carlos Alberto de (Org.) Processo Civil e Interesse Público: o processo como instrumento de defesa social. São Paulo: Revista dos Tribunais, 2003. pp. 39/77.

SANTOS, Moacyr Amaral. Primeiras Linhas de Direito Processual Civil, vol. 1. 2. ed. São Paulo: Max Limonad, 1965.

SHELL, G. Richard. Bargaining for Advantage. 2. ed. New York: Penguin, 2006.

SILVA, José Afonso da. Curso de Direito Constitucional Positivo. 16. ed. rev. e atual. São Paulo: Malheiros, 1999.

TARUFFO, Michele. Precedente e jurisprudência. Revista de Processo, São Paulo, 2011, n. 199, p. 139. 
TUCCI, José Rogério Cruz e. Limites subjetivos da eficácia da sentença e da coisa julgada. São Paulo: RT, 2007.

WATANABE, Kazuo. Acesso à Justiça e Sociedade Moderna. In: DINAMARCO, Cândido Rangel; GRINOVER, Ada Pellegrini; WATANABE, Kazuo (Coord.). Participação e Processo. São Paulo: Editora Revista dos Tribunais, 1988, pp. 128/135.

Da Cognição no Processo Civil. 2. ed. Atual.

São Paulo: Central de Publicações Jurídicas: Centro Brasileiro de Estudos e Pesquisas Judiciais, 1999.

Relação entre Demanda Coletiva e Demandas

Individuais. In GRINOVER, Ada Pellegrini; MENDES, Aluisio Gonçalves de Castro; WATANABE, Kazuo (coord.). Direito Processual e o Anteprojeto de Código Brasileiro de Processos Coletivos. São Paulo: Revista dos Tribunais, 2007, pp.156/160.

Controle Jurisdicional de Políticas Públicas "Mínimo Existencial" e Demais Direitos Fundamentais. In: GRINOVER, Ada Pellegrini; WATANABE, Kazuo (Coord.). O controle jurisdicional de políticas públicas. Rio de Janeiro: Forense, 2011, pp. 213/224.

In: GRINOVER, Ada Pellegrini; NERY JUNIOR, Nelson; WATANABE, Kazuo. Código Brasileiro de Defesa do Consumidor: comentado pelos autores do anteprojeto, Vol. II: Processo Coletivo (arts. 81 a 104 e 109 a 119), 10. ed. Rio de Janeiro: Forense, 2011.

A Mentalidade e os Meios Alternativos de Solução de Conflitos no Brasil. In GRINOVER, Ada Pellegrini; LAGRASTA NETO, Caetano; WATANABE, Kazuo (coord.). Mediação e Gerenciamento do Processo: revolução na prestação jurisdicional. São Paulo: Atlas, 2013.

WEFFORT, Francisco (Org.). Os Clássicos da Política, $1^{\text {o }}$ vol. 5. ed. São Paulo: Ática, 1995. 
VIGLIAR, José Marcelo Menezes. Interesses Individuais Homogêneos e Seus Aspectos Polêmicos. 2. ed. rev. e atual. São Paulo: Saraiva, 2008.

ZUFELATO, Camilo. Coisa Julgada Coletiva. São Paulo: Saraiva, 2011. 